WSRC-STI-2008-00203, REV. 0

\title{
CHARACTERIZATION OF SAMPLES FROM TANK 16H ANNULUS
}

May 2008

Waste Processing Technology Section Savannah River National Laboratory Aiken, SC 29808

Prepared for the U.S. Department of Energy Under Contract Number DEAC09-96SR18500

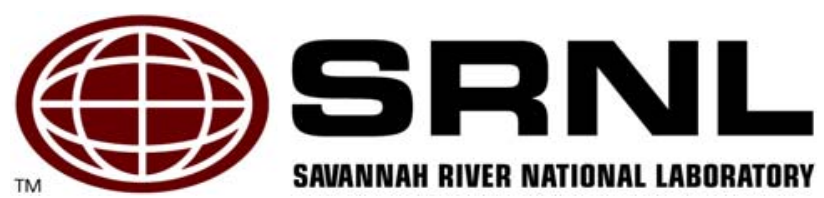




\title{
DISCLAIMER
}

This report was prepared for the United States Department of Energy under Contract No. DE-AC09-96SR18500 and is an account of work performed under that contract. Neither the United States Department of Energy, nor WSRC, nor any of their employees makes any warranty, expressed or implied, or assumes any legal liability or responsibility for the accuracy, completeness, or usefulness, of any information, apparatus, or product or process disclosed herein or represents that its use will not infringe privately owned rights. Reference herein to any specific commercial product, process, or service by trade name, trademark, name, manufacturer or otherwise does not necessarily constitute or imply endorsement, recommendation, or favoring of same by Westinghouse Savannah River Company or by the United States Government or any agency thereof. The views and opinions of the authors expressed herein do not necessarily state or reflect those of the United States Government or any agency thereof.

\author{
Printed in the United States of America \\ Prepared For \\ U.S. Department of Energy
}


Key Words:

Solids Analysis

Salt Analysis

Sodium Aluminum Silicate

Retention: Permanent

Key References:

Sampling Plan: CBU-PIT-2006-00091, Rev. 0

Technical Task Request: HLE-TTR-2006-011

Task Plan: WSRC-RP-2006-00844, Rev. 0

Analytical Plan: SRNL-CST-2006-00087

\section{CHARACTERIZATION OF SAMPLES FROM TANK 16H ANNULUS}

M. S. Hay, SRNL/A\&CPT

Issue Date: May 2008

Waste Processing Technology Section Savannah River National Laboratory Aiken, SC 29808

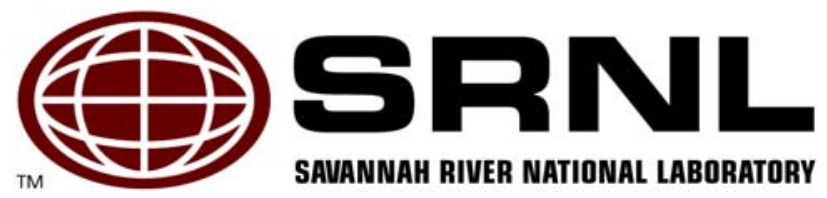


WSRC-STI-2008-00203, REV. 0

\section{REVIEWS AND APPROVALS}

M. S. Hay, Author, SRNL/A\&CPT

Date

S. D. Fink, SRNL/SSP, Manager

Date

D. J. McCabe, Technical Reviewer, SRNL/A\&CPT

Date

M. T. Keefer, Technology Development and Tank Closure

Date 


\section{TABLE OF CONTENTS}

List of Tables $\quad$ iv

$\begin{array}{ll}\text { List of Figures } & \text { v }\end{array}$

List of Acronyms

$\begin{array}{ll}\text { SUMMARY ix } & \text { ix }\end{array}$

$\begin{array}{ll}1.0 \text { INTRODUCTION } & 1\end{array}$

2.0 SAMPLE DESCRIPTION AND PREPARATION 2

2.1 SAMPLING OF TANK 16H ANNULUS 2

2.2 SAMPLE DESCRIPTION $\quad 4$

2.3 SAMPLE PREPARATION FOR ANALYSIS $\quad 7$

3.0 RESULTS OF THE SAMPLE CHARACTERIZATION 9

3.1 GENERAL INFORMATION 9

3.2 RESULTS OF THE ANALYSIS OF SOLIDS FROM IP-35 SAMPLE FROM INSIDE THE DEHUMIDIFICATION DUCT

(HTF-16-06-104) 10

3.3 RESUlTS OF THE ANALYSIS OF SOLIDS FROM IP-35 SAMPLE FROM OUTSIDE THE DEHUMIDIFICATION DUCT (HTF-16-06-105)

3.4 RESULTS OF THE ANALYSIS OF SOLIDS FROM IP-118 SAMPLE (HTF-16-06-106) 12

\section{$\begin{array}{ll}\text { 4.0 DISCUSSION OF RESULTS } & 71\end{array}$}

4.1 CHARACTERIZATION OF THE IP-35 SAMPLE FROM INSIDE THE DEHUMIDIFICATION DUCT (HTF-16-06-104)71 4.2 CHARACTERIZATION OF THE IP-35 SAMPLE FROM OUTSIDE THE DEHUMIDIFICATION DUCT (HTF-16-06-

105)

4.3 CHARACTERIZATION OF THE IP-118 SAMPLE FROM OUTSIDE THE DEHUMIDIFICATION DUCT (HTF-16-06106)

4.4 ESTIMATED WATER SOlubility OF THE TANK 16H ANNULUS SAMPLES 


\section{List of Tables}

TABLE S-1. SimPLIFIED COMPOSITION OF THE TANK 16H ANNULUS SAMPLES ............................................... IX

TABLE 2-1. COMPOSITION OF THE ANALYTICAL REFERENCE GLASS-1 STANDARD...........................................8

TABLE 3-1. ABBREVIATIONS FOR ANALYTICAL METHODS USED IN DATA TABLES ............................................9

TABle 3-4. COMPOSITION OF THE CESIUM Hydroxide Fusion DisSOlution OF SOLIDS FROM SAMPLE HTF16-06-104.

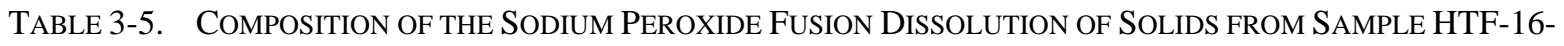
06-104 16

TABle 3-6. COMPOSITION OF THE CESIUM Hydroxide FUSION DisSOLUTION OF SOLIDS FROM SAMPLE HTF-

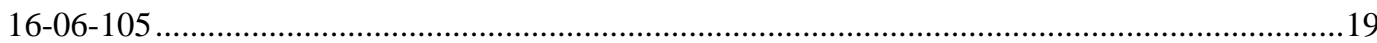

TABle 3-7. COMPOSITION OF THE SODIUM PEROXIDE Fusion DisSOLUTION OF SOLIDS FROM SAMPLE HTF-1606-105

TABle 3-8. COMPosition OF THE CESIUM Hydroxide Fusion DisSOlUtion OF SOLIDS FROM SAMPLE HTF16-06-106. . .24

TABle 3-9. COMPOSITION OF THE SODIUM PEROXIDE FUSION DisSOLUTION OF SOLIDS FROM SAMPLE HTF-16-

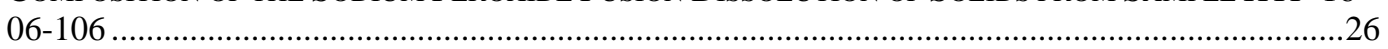

TABle 3-10. Composition of the Water Soluble Portion OF Solids From SAMPle HTF-16-06-104 .......29

TABle 3-11. COMPOSITION OF THE WATER SOLUBLE PORTION OF SOLIDS FROM SAMPLE HTF-16-06-105 .........31

TABle 3-12. Composition of the WATER Soluble Portion OF SOlidS From SAMPLE HTF-16-06-106 .........33

TABle 4-1. Summary of THE Solids COMPOSITION OF TANK 16H ANNUlus SAMPlE From IP-35 INSIDE THE DEHUMIDIFICATION DUCT (HTF-16-06-104) .71

TABle 4-2. SUMMARY OF THE WATER SOLUBlE FRACTION OF THE TANK 16H ANNULUS SAMPLE FROM IP-35 INSIDE THE DEHUMIDIFICATION DUCT (HTF-16-06-104) .........................................................72

Table 4-3. Mineral Phases IdENTIFIED In The TANK 16H ANnUlus SAMPle From IP-35 Inside THE

TABLE 4-4. SUMMARY OF THE SOLIDS COMPOSITION OF TANK 16H ANNULUS SAMPLE FROM IP-35 OUTSIDE THE DEHUMIDIFICATION DUCT (HTF-16-06-105) .............................................................73

TABle 4-5. SUMMARY OF THE WATER SOLUblE FrACtion OF THE TANK 16H ANNULUS SAMPLE FROM IP-35 OUTSIDE THE DEHUMIDIFICATION DUCT (HTF-16-06-105) .........................................................73

Table 4-6. Mineral Phases Identified in the TANK 16H AnNulus SAMPle From IP-35 OUtSide THE DEHUMIDIFICATION DUCT (HTF-16-06-105 - COMPOSITE)....................................................74

Table 4-7. Mineral Phases Identified in the TANK 16H AnNulus SAMPle From IP-35 OUtSide The DEHUMIDIFICATION DUCT (HTF-16-06-105 - SECTION C) 72 73

$\begin{array}{ll}\text { TABLE 4-8. } & \text { SUMMARY OF THE SOLIDS COMPOSITION OF TANK 16H ANNULUS SAMPLE FROM IP-118 OUTSIDE } \\ & \text { THE DEHUMIDIFICATION DUCT (HTF-16-06-106) ….........................................................................75 } \\ \text { TABLE 4-9. } & \text { SUMMARY OF THE WATER SOLUBLE FRACTION OF THE TANK 16H ANNULUS SAMPLE FROM IP-118 }\end{array}$

$\begin{array}{ll}\text { TABLE 4-8. } & \text { SUMMARY OF THE SOLIDS COMPOSITION OF TANK 16H ANNULUS SAMPLE FROM IP-118 OUTSIDE } \\ & \text { THE DEHUMIDIFICATION DUCT (HTF-16-06-106) …..................................................................75 } \\ \text { TABLE 4-9. } & \text { SUMMARY OF THE WATER SOLUBLE FrACTION OF THE TANK } 16 \text { H ANNULUS SAMPLE FROM IP-118 }\end{array}$ OUTSIDE THE DEHUMIDIFICATION DUCT (HTF-16-06-106) .........................................................75

TABle 4-10. Mineral Phases IDENTIFIEd in the TANK 16H AnNulus SAMPle From IP-118 OuTSIDE THE DEHUMIDIFICATION DUCT (HTF-16-06-106 - SECTION D) ...............................................76

TABle 4-11. Mineral Phases IDENTIFIEd In The TANK 16H ANNUlus SAMPLE FROM IP-118 OUTSIDE THE DEHUMIDIFICATION DUCT (HTF-16-06-105 - SECTION A) ....................................................76

TABle 4-12. Estimate of THE SOlubility OF THE MATERIAL IN THE TANK 16H ANNULUS SAMPLES ..............77

TABLE 4-13. XRD RESULTS FOR THE TANK 16H ANNULUS SAMPLES...........................................................78

TABLE 4-14. SimPLifIED COMPOSITION OF THE TANK 16H ANNULUS SAMPLES .............................................79 


\section{List of Figures}

FIGURE 1.1 PHOTOGRAPHS OF THE TANK 16H ANNULUS ..........................................................................

FigURE 2.1 PHOTOGRAPHS FROM IP-118 OF THE TANK 16H ANNULUS.............................................................2

FigURE 2.2 PHOTOGRAPHS FROM IP-35 OF THE TANK 16H ANNULUS.............................................................

Figure 2.3 PHOTOGRAPH OF THE CORE SAMPLER USED FOR SAMPLING THE TANK 16H ANNULUS ....................

FIGURE 2.4 SAMPLE SECTIONS REMOVED FROM IP-118 CORE SAMPLE ...........................................................

FiguRE 2.5 SAMPLE SECTIONS REMOVED FROM IP-35 CORE SAMPLE INSIDE THE DUCT.....................................

Figure 2.6 SAMPLE SECTIONS REMOVED FROM IP-35 CoRe SAMPLE OUTSIDE THE DuCT ..............................6

FIGURE 3.1 X-RAY DIFFRACTION FOR SOLIDS FROM TANK 16H SAMPLE HTF-16-06-104 ……............................

FIGURE 3.2 X-RAY DIFFRACTION FOR SOLIDS FROM TANK 16H SAMPLE HTF-16-06-105C .............................36

FIGURE 3.3 X-RAY DIFFRACTION FOR SOLIDS FROM TANK 16H SAMPLE HTF-16-06-105 ..............................36

FIGURE 3.4 X-RAY DIFFRACTION FOR SOLIDS FROM TANK 16H SAMPLE HTF-16-06-106-ABOT .....................37

FigURE 3.5 X-RAY DifFRACTION FOR SOLIDS FROM TANK 16H SAMPLE HTF-16-06-106-ATOP ....................37

FigURE 3.6 SEM MiCROGRAPH OF SOLIDS FROM TANK 16H SAMPLE HTF-16-06-104-2 (15X

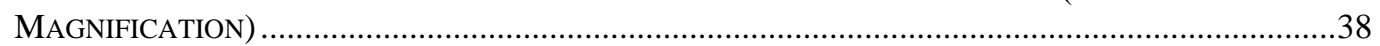

FIGURE 3.7 SPECTRUM OF RASTER SCAN FROM FIGURE 3.6 …...................................................................38

FiguRE 3.8 SEM MiCROGRAPH OF SOLIDS FROM TANK 16H SAMPLE HTF-16-06-104-2 (130X

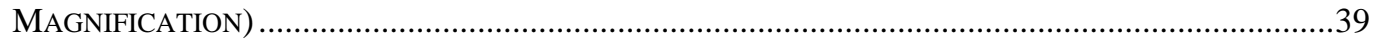

FIGURE 3.9 SPECTRUM OF SPOT 1 FROM FIGURE 3.8.................................................................................39

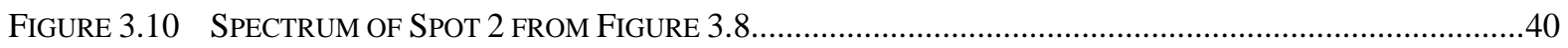

FIGURE 3.11 SPECTRUM OF SPOT 3 FROM FIGURE 3.8............................................................................

Figure 3.12 SEM MicROGRAPH OF SOLIDS FROM TANK 16H SAMPLE HTF-16-06-104-2 (250X

MAGNIFICATION) …………………………………......................................................4

FIGURE 3.13 SPECTRUM OF SPOT 4 FROM FIGURE 3.12........................................................................

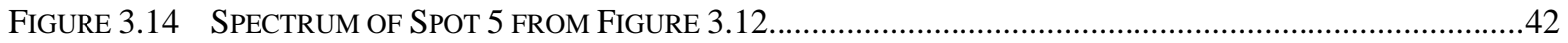

FIGURE 3.15 SPECTRUM OF SPOT 6 FROM FIGURE 3.12.............................................................................42

FigurE 3.16 SEM MicROGRAPH OF SOLIDS FROM TANK 16H SAMPLE HTF-16-06-104-2 (277X

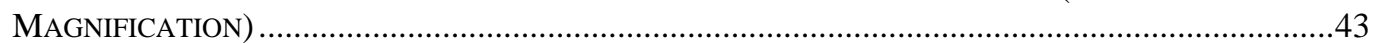

FIGURE 3.17 SPECTRUM OF SPOT 7 FROM FIGURE 3.16 ..............................................................................

FIGURE 3.18 SPECTRUM OF SPOT 8 FROM FIGURE 3.16 ...........................................................................

FigurE 3.19 SEM MiCROGRAPH OF SOLIDS FROM TANK 16H SAMPLE HTF-16-06-105-1 (18X

MAGNIFICATION) ................................................................................................................45

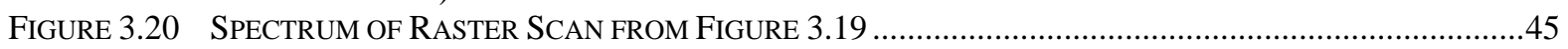

FigurE 3.21 SEM MiCROGRAPH OF SOLIDS FROM TANK 16H SAMPLE HTF-16-06-105-1 (100X

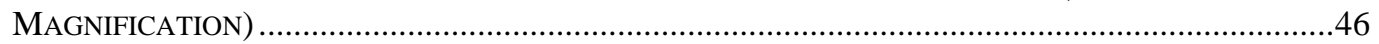

FIGURE 3.22 SPECTRUM OF SPOT 1 FROM FIGURE 3.21..............................................................................46

FIGURE 3.23 SPECTRUM OF SPOT 2 FROM FIGURE 3.21..........................................................................

FigurE 3.24 SEM MiCROGRAPH OF SOLIDS FROM TANK 16H SAMPLE HTF-16-06-105-1 (30X

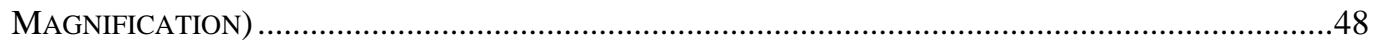

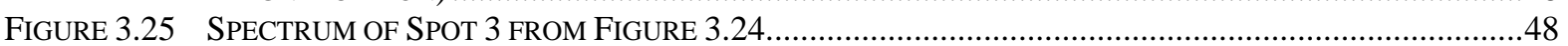

Figure 3.26 SEM MicROGRAPH OF SOLIDS FROM TANK 16H SAMPLE HTF-16-06-105-1 (350X

MAGNIFICATION) ………………………………….....................................................49

FIGURE 3.27 SPECTRUM OF SPOT 4 FROM FIGURE 3.26 .............................................................................49

FigurE 3.28 SEM MiCROGRAPH OF SOLIDS FROM TANK 16H SAMPLE HTF-16-06-105-1 (350X

MAGNIFICATION) .............................................................................................................50

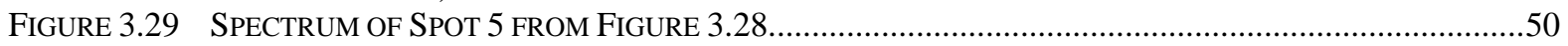

FigURE 3.30 SEM MiCROGRAPH OF SOLIDS FROM TANK 16H SAMPLE HTF-16-06-105C-1 (18X

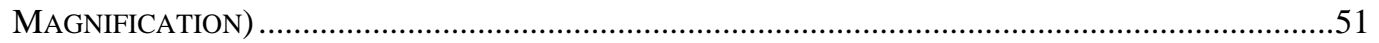

FIGURE 3.31 SPECTRUM OF RASTER SCAN FROM FIGURE 3.30 …..............................................................51

FigURE 3.32 SEM MicROGRAPH OF SOLIDS FROM TANK 16H SAMPLE HTF-16-06-105C-1 (400X

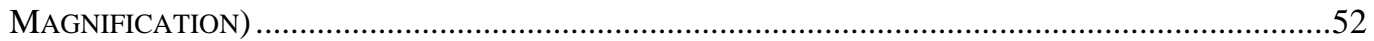

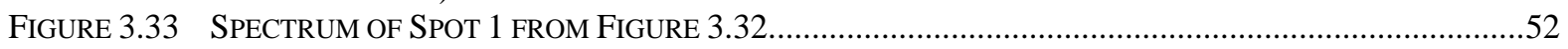


FigURE 3.34 SPECTRUM OF SPOT 2 FROM FIGURE 3.32 _..................................................................................53

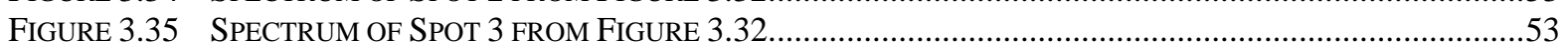

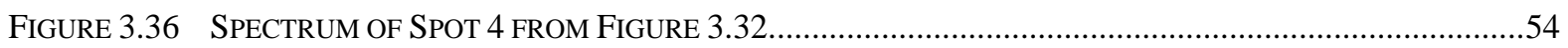

Figure 3.37 SEM MiCROGRAPH OF SOLIDS FROM TANK 16H SAMPLE HTF-16-06-105C-1 (375X

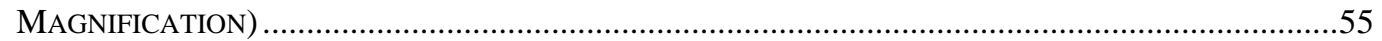

FIGURE 3.38 SPECTRUM OF SPOT 5 FROM FIGURE 3.37

FIGURE 3.39 SPECTRUM OF SPOT 6 FROM FIGURE 3.37 .............................................................................56

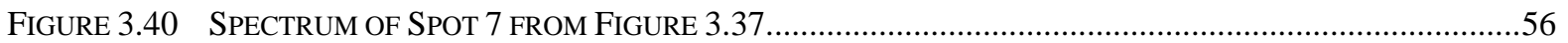

FIGURE 3.41 SPECTRUM OF SPOT 8 FROM FIGURE 3.37 .........................................................................5

FigURE 3.42 SEM MicROGRAPH OF SOLIDS FROM TANK 16H SAMPLE HTF-16-06-106ATOP-2

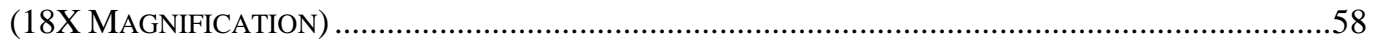

FIGURE 3.43 SPECTRUM OF SPOT 1 FROM FIGURE 3.42 ...............................................................................58

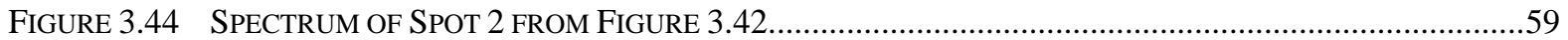

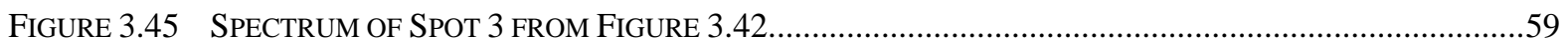

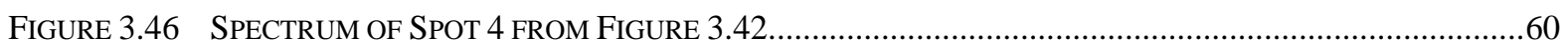

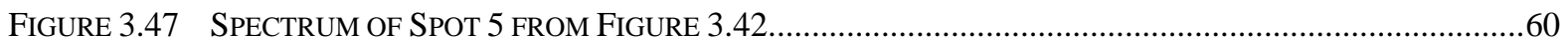

FIGURE 3.48 SPECTRUM OF SPOT 6 FROM FIGURE 3.42 ................................................................................61

FiguRE 3.49 SEM MicROGRAPH OF SOLIDS FROM TANK 16H SAMPLE HTF-16-06-106ATOP-2

(1000X MAGNIFICATION) ......................................................................................................62

FIGURE 3.50 SPECTRUM OF SPOT 9 FROM FIGURE 3.49...........................................................................62

FIGURE 3.51 SPECTRUM OF SPOT 10 FROM FIGURE 3.49........................................................................63

Figure 3.52 SEM MicROGRAPH OF SOLIDS FROM TANK 16H SAMPLE HTF-16-06-106ABOT-2

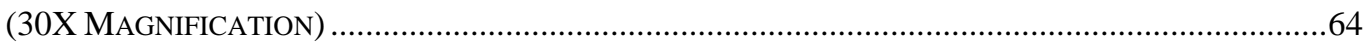

FIGURE 3.53 SPECTRUM OF RASTER SCAN FROM FIGURE 3.52 ….............................................................64

FIGURE 3.54 SPECTRUM OF SPOT 2 FROM FIGURE 3.52 .................................................................................65

FIGURE 3.55 SPECTRUM OF SPOT 3 FROM FIGURE 3.52 ............................................................................65

FiguRE 3.56 SEM MicROGRAPH OF SOLIDS FROM TANK 16H SAMPLE HTF-16-06-106ABOT-2

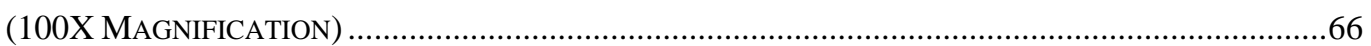

FIGURE 3.57 SPECTRUM OF SPOT 4 FROM FIGURE 3.56 ................................................................................66

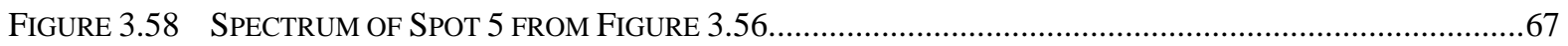

FIGURE 3.59 SPECTRUM OF SPOT 6 FROM FIGURE 3.56.............................................................................67

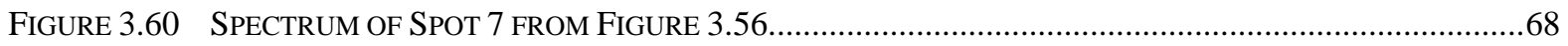

Figure 3.61 SEM MicROGRAPH OF SOLIDS FROM TANK 16H SAMPLE HTF-16-06-106ABOT-2

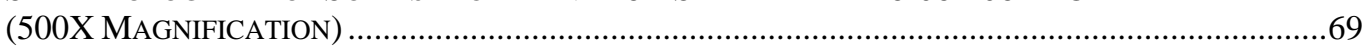

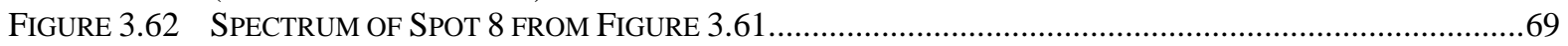

FIGURE 3.63 SPECTRUM OF SPOT 9 FROM FIGURE 3.61 ...............................................................................70

FIGURE 3.64 SPECTRUM OF SPOT 10 FROM FIGURE 3.61................................................................................70

FigurE A.1 SEM MicROGRAPH OF SOLIDS FROM TANK 16H SAMPLE HTF-16-06-104-1 (69X

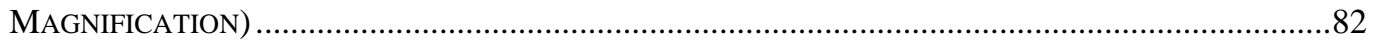

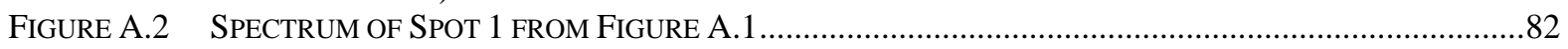

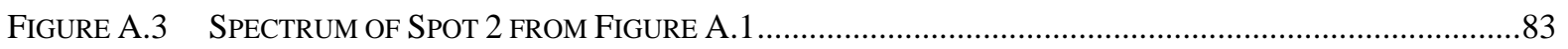

FIGURE A.4 SPECTRUM OF SPOT 3 FROM FIGURE A.1 ...................................................................................83

FigURE A.5 SEM MiCROGRAPH OF SOLIDS FROM TANK 16H SAMPLE HTF-16-06-104-1 (375X

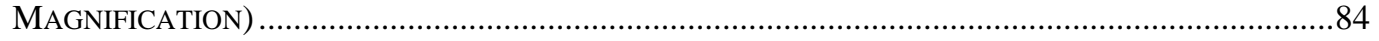

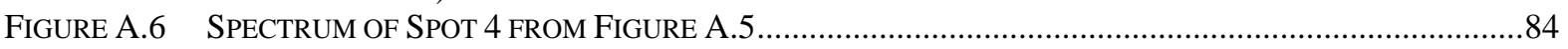

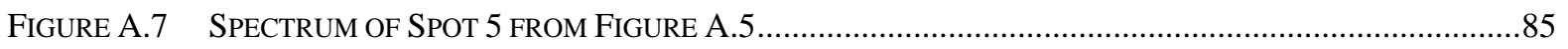

FIGURE A.8 SPECTRUM OF SPOT 6 FROM FIGURE A.5

FIGURE A.8 SPECTRUM OF SPOT 7 FROM FIGURE A.5 ................................................................................

FigurE A.9 SEM MicROGRAPH OF SOLIDS FROM TANK 16H SAMPLE HTF-16-06-105-2 (18X

MAGNIFICATION) ..................................................................................................................8

FIGURE A.10 SPECTRUM OF RASTER SCAN FROM FIGURE A.9 …................................................................87

FIGURE A.11 SEM MicROGRAPH OF SOLIDS FROM TANK 16H SAMPLE HTF-16-06-105-2 (150X

MAGNIFICATION) .....................................................................................................8

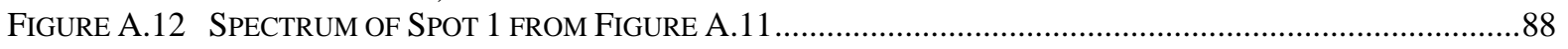

FIGURE A.13 SPECTRUM OF SPOT 2 FROM FIGURE A.11 .................................................................................89

FIGURE A.14 SPECTRUM OF SPOT 3 FROM FIGURE A.11 ..............................................................................89 
FIGURE A.15 SPECTRUM OF SPOT 4 FROM FIGURE A.11 .90

FIGURE A.16 SEM MiCROGRAPH OF SOLIDS FROM TANK 16H SAMPLE HTF-16-06-105-2 (800X MAGNIFICATION)

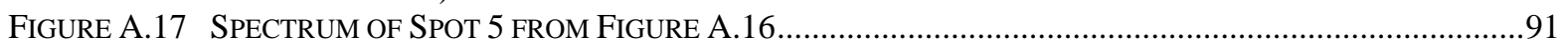

FIGURE A.18 SPECTRUM OF SPOT 6 FROM FIGURE A.16 ........................................................................92

FIGURE A.19 SPECTRUM OF SPOT 7 FROM FIGURE A.16 ....................................................................92

FIGURE A.20 SEM MiCROGRAPH OF SOLIDS FROM TANK 16H SAMPLE HTF-16-06-105C-2 (18X

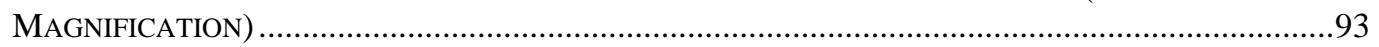

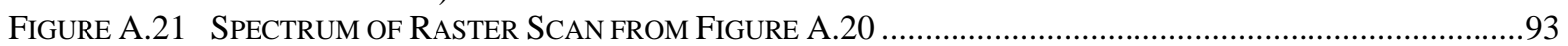

FIgURE A.22 SEM MiCROGRAPH OF SOLIDS FROM TANK 16H SAMPLE HTF-16-06-105C-2 (143X

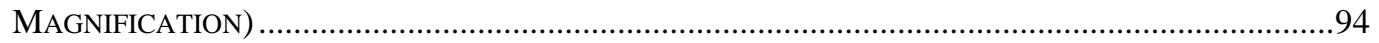

FIGURE A.23 SPECTRUM OF SPOT 1 FROM FIGURE A.22 ..................................................................94

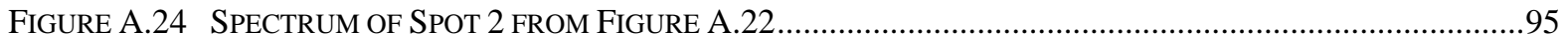

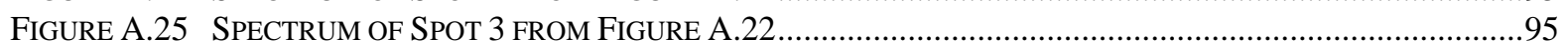

FIGURE A.26 SEM MICROGRAPH OF SOLIDS FROM TANK 16H SAMPLE HTF-16-06-105C-2

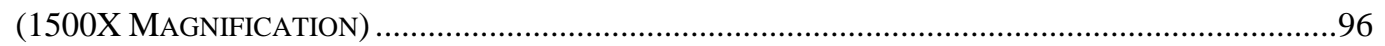

FIGURE A.27 SPECTRUM OF SPOT 4 FROM FIGURE A.26 .....................................................................96

FigURE A.28 SPECTRUM OF SPOT 5 FROM FIGURE A.26 .................................................................97

FIgURE A.29 SEM MiCROGRAPH OF SOLIDS FROM TANK 16H SAMPLE HTF-16-06-106ATOP-1

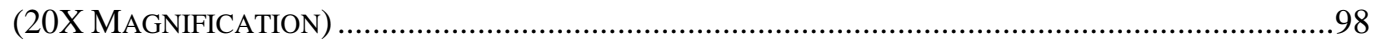

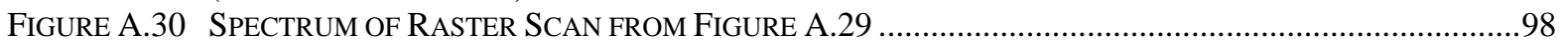

FIGURE A.31 SPECTRUM OF SPOT 2 FROM FIGURE A.29 ..........................................................................99

FIGURE A.32 SPECTRUM OF SPOT 3 FROM FIGURE A.29 ............................................................................99

FIGURE A.33 SPECTRUM OF SPOT 4 FROM FIGURE A.29 ....................................................................... 100

FIGURE A.34 SEM MiCROGRAPH OF SOLIDS FROM TANK 16H SAMPLE HTF-16-06-106ATOP-1

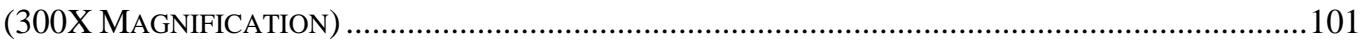

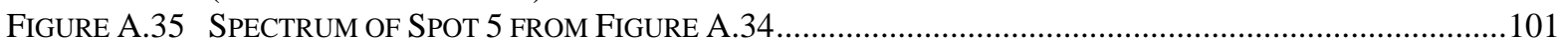

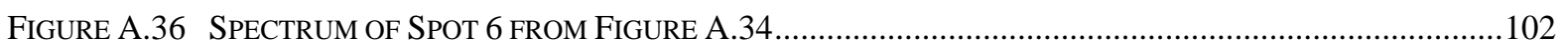

FIGURE A.37 SPECTRUM OF SPOT 7 FROM FIGURE A.34 ................................................................102

Figure A.38 SEM MicROGRAPH OF SOLIDS FROM TANK 16H SAMPLE HTF-16-06-106ABOT-1

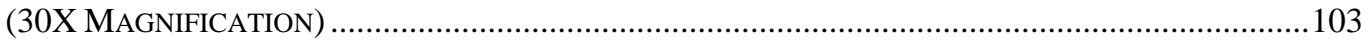

FIGURE A.39 SPECTRUM OF RASTER SCAN FROM FIGURE A.38 ….......................................................103

FigurE A.40 SEM MiCROGRAPH OF SOLIDS FROM TANK 16H SAMPLE HTF-16-06-106ABOT-1

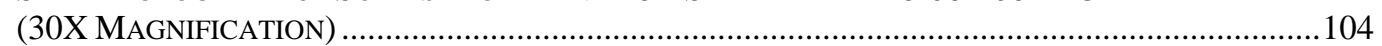

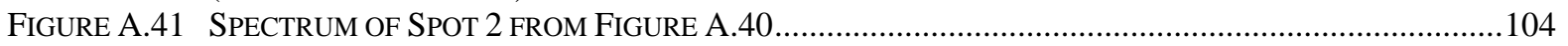

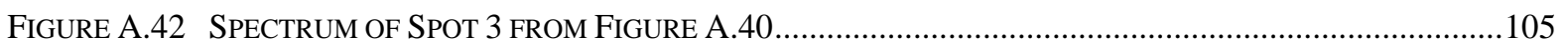

Figure A.43 SEM MicROGRAPH OF SOLIDS FROM TANK 16H SAMPLE HTF-16-06-106ABOT-1

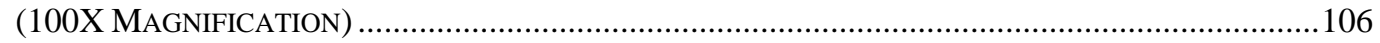

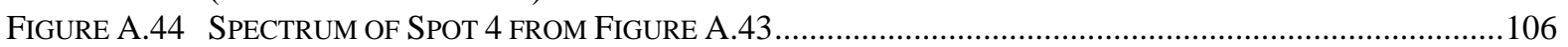

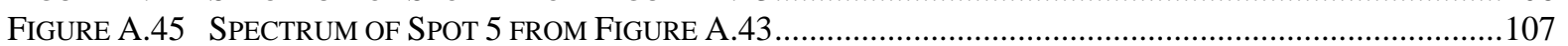

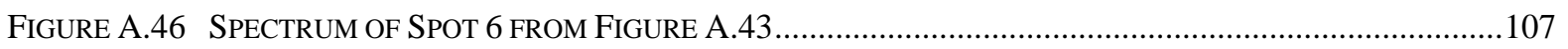

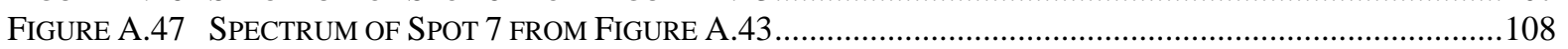

FigurE A.48 SEM MiCROGRAPH OF SOLIDS FROM TANK 16H SAMPLE HTF-16-06-106ABOT-1

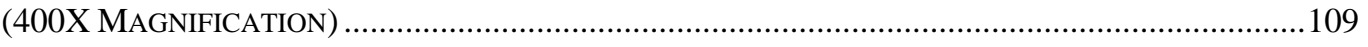

FIGURE A.49 SPECTRUM OF SPOT 8 FROM FIGURE A.48 ............................................................... 109 


\section{List of Acronyms}

$\begin{array}{ll}\text { SRNL } & \text { Savannah River National Laboratory } \\ \text { IP } & \text { Inspection Port } \\ \text { XRD } & \text { X-ray Diffraction } \\ \text { CSEM } & \text { Contained Scanning Electron Microscopy } \\ \text { AD } & \text { Analytical Development } \\ \text { ARG-1 } & \text { Analytical Reference Glass 1 } \\ \text { \%RSD } & \text { Percent Relative Standard Deviation } \\ \text { IE } & \text { Inductively Couple Plasma-Emission Spectroscopy } \\ \text { IM } & \text { Inductively Couple Plasma-Mass Spectrometry } \\ \text { IC } & \text { Ion Chromatography } \\ \text { TH } & \text { Titration for Free Hydroxide } \\ \text { TIC } & \text { Total Inorganic Carbon } \\ \text { SA } & \text { Separation/Alpha Spectroscopy } \\ \text { EDX } & \text { Energy Dispersive X-Ray Spectroscopy }\end{array}$




\section{SUMMARY}

In support of the closure of Tank $16 \mathrm{H}$, the remaining waste material in the tank annulus must be removed. Samples of the waste material from Tank $16 \mathrm{H}$ annulus were obtained and sent to Savannah River National Laboratory (SRNL) to determine the chemical and radiochemical composition prior to further waste removal.

The three samples obtained from the Tank $16 \mathrm{H}$ annulus show some similarity as to the types of mineral phases present in the materials but differ in the relative amounts of each phase present. The samples from outside the dehumidification duct at two locations in the annulus show very different compositions and estimated solubility in water. This indicates the waste material in Tank 16H annulus may have a wide range of compositions at different locations.

The table below provides a simplified description of the composition of each sample. The limited characterization techniques conducted and the complex mixture of materials in each sample makes assigning a definitive composition for each sample difficult. Given the variability in composition with just the three small samples characterized, a more detailed description of any single sample may be of limited value.

\section{Table S-1. Simplified Composition of the Tank 16H Annulus Samples}

\begin{tabular}{|l|c|c|c|}
\hline Mineral Phases & $\begin{array}{c}\text { Fraction found in } \\
\text { HTF-16-06-104 }\end{array}$ & $\begin{array}{c}\text { Fraction found in } \\
\text { HTF-16-06-105 }\end{array}$ & $\begin{array}{c}\text { Fraction found in } \\
\text { HTF-16-06-106 }\end{array}$ \\
\hline Sodium Aluminum Silicates/Sand & small fraction & large fraction & large fraction \\
\hline Aluminum Hydroxides & moderate fraction & small fraction & moderate fraction \\
\hline Sodium Carbonates & large fraction & large fraction & small fraction \\
\hline Sodium Nitrate/Nitrite & large fraction & moderate fraction & moderate fraction \\
\hline
\end{tabular}

Small fraction $<5 \%$, Moderate fraction $>5 \%$ to $<30 \%$, Large fraction $>30 \%$ 


\subsection{INTRODUCTION}

In support of the closure of Tank $16 \mathrm{H}$, the remaining waste material in the tank annulus must be removed. Tank $16 \mathrm{H}$, a type II tank, has a $5 \mathrm{ft}$ high steel annulus pan to collect any leakage from the primary tank. A dehumidification duct runs around the bottom of the annulus and ranges in diameter from 12" to 20". Approximately 4760 gal of waste remains in the tank annulus. ${ }^{1}$ From photographic inspections of the annulus, the waste resides between the exterior wall of the primary tank and the dehumidification duct, between the duct and the wall of the annulus pan, and within the interior of the duct. The depth of the waste deposits in the annulus varies from approximately 8" to 15 " thick. Figure 1.1 shows photographs of the inside of the Tank $16 \mathrm{H}$ annulus. Samples of the waste material from Tank $16 \mathrm{H}$ annulus were obtained and sent to SRNL to determine the chemical and radiochemical composition prior to further waste removal. A Technical Task Request ${ }^{2}$ detailing the required characterization, a Task Technical and Quality Assurance Plan ${ }^{3}$, and an Analytical Study Plan ${ }^{4}$ were generated for the task.

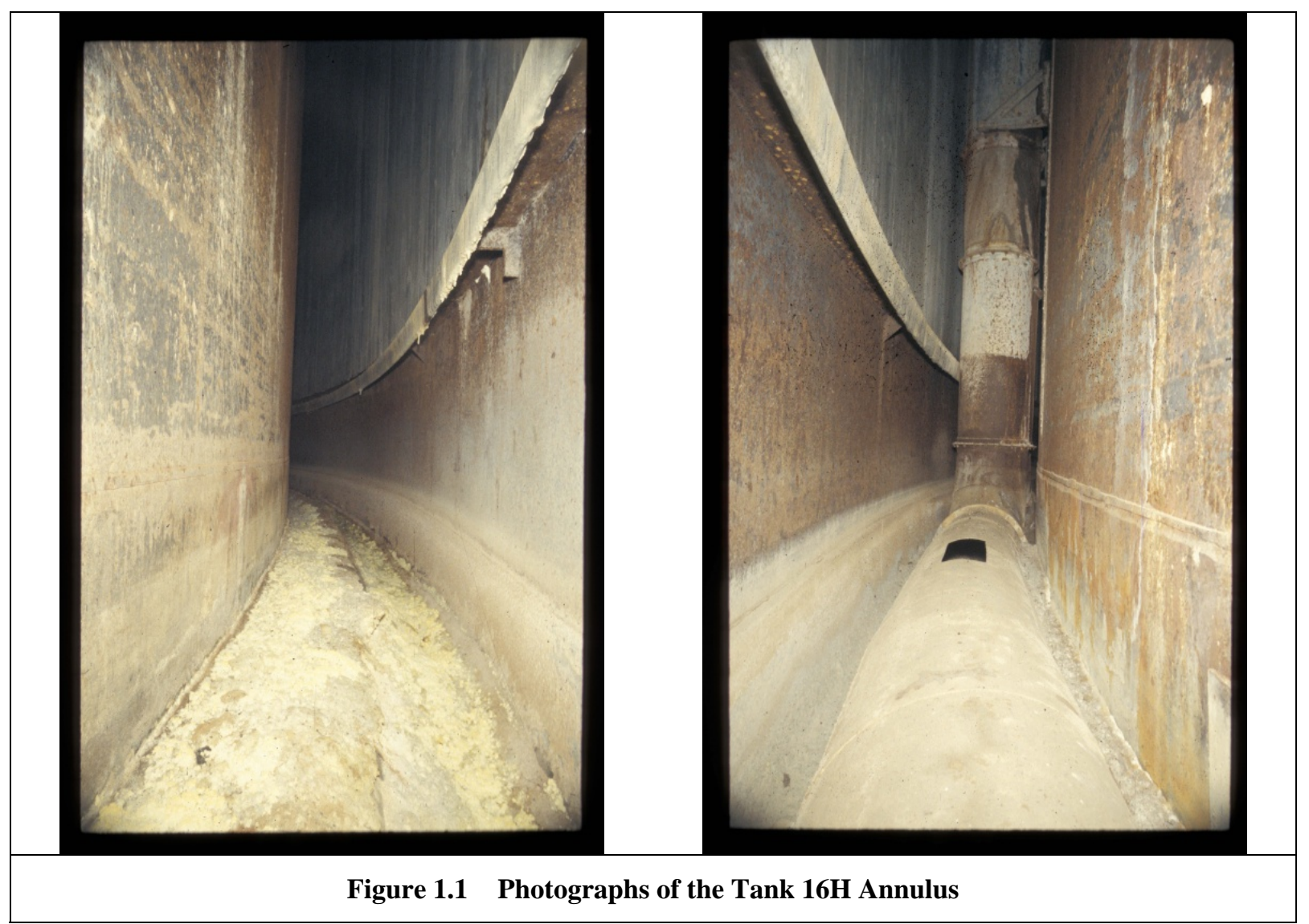




\subsection{SAMPLE DESCRIPTION AND PREPARATION}

\subsection{SAMPLING OF TANK 16H ANNULUS}

Three core samples from the annulus of Tank 16H were received at SRNL for characterization. The first core sample was obtained from Inspection Port (IP) 118 with a sample ID of HTF-16-06-106. The IP-118 core sample arrived at SRNL on December 11, 2006. Figure 2.1 provides photographs taken from inside IP-118. Two more core samples were obtained from IP-35, one from inside the dehumidification duct (HTF-16-06-104), and one from outside the duct (HTF-16-06-105). Both of these samples arrived at SRNL on February 6, 2007. Figure 2.2 shows the waste levels at IP-35. The sample obtained from inside the dehumidification duct was obtained by using a modified hole saw to cut a small circular opening in the duct through which the core sampler was inserted. A planned fourth core sample from IP-262 was determined to be unnecessary after review of initial data from the first three core samples. ${ }^{5}$

Figure 2.3 shows a photograph of the core sampler used to obtain the samples from the Tank $16 \mathrm{H}$ annulus. The $\sim 12$ " long core sampler has a diameter of approximately 1 " with internal threads on one end for attachment to the sampling mast and a sharpened bevel on the other end to cut through the waste material.

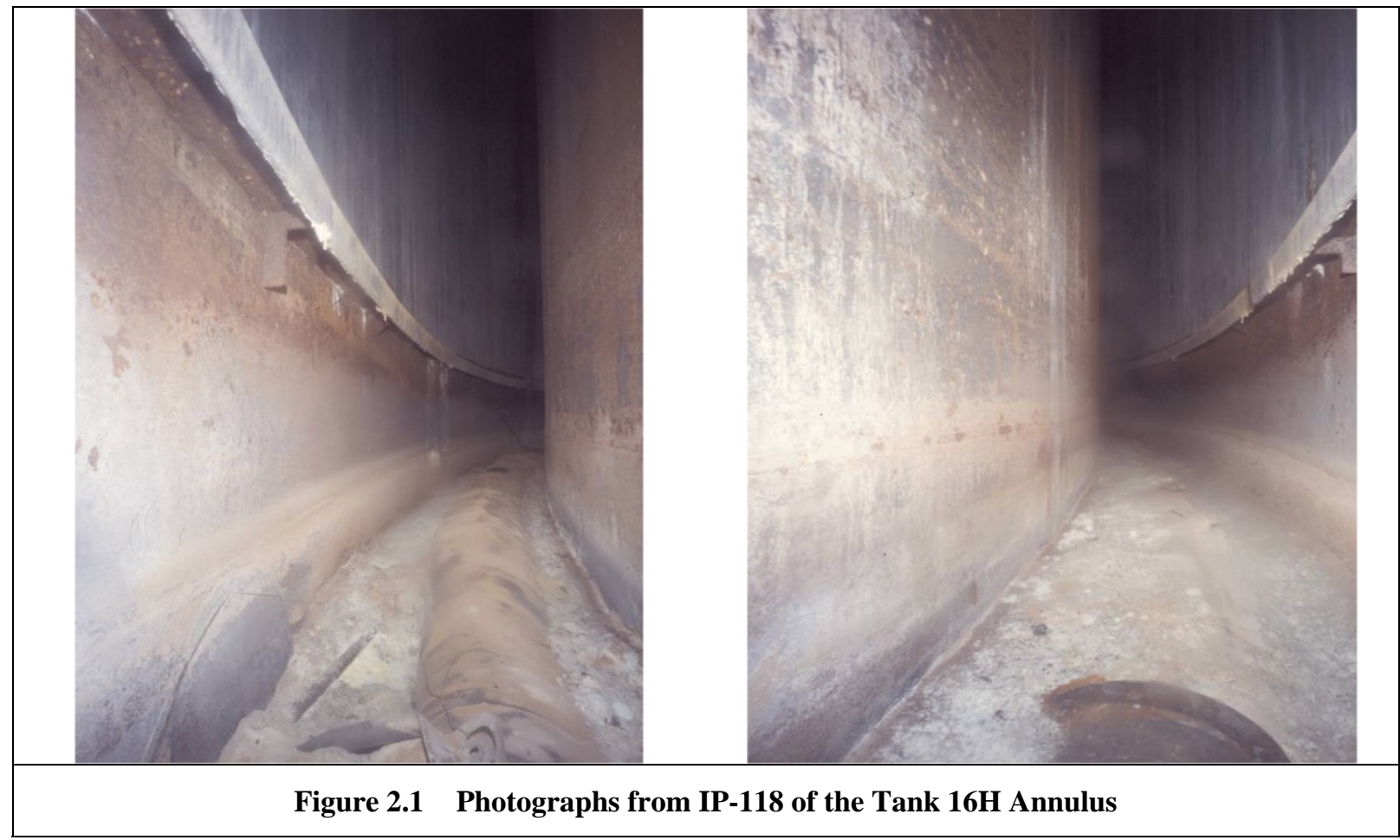




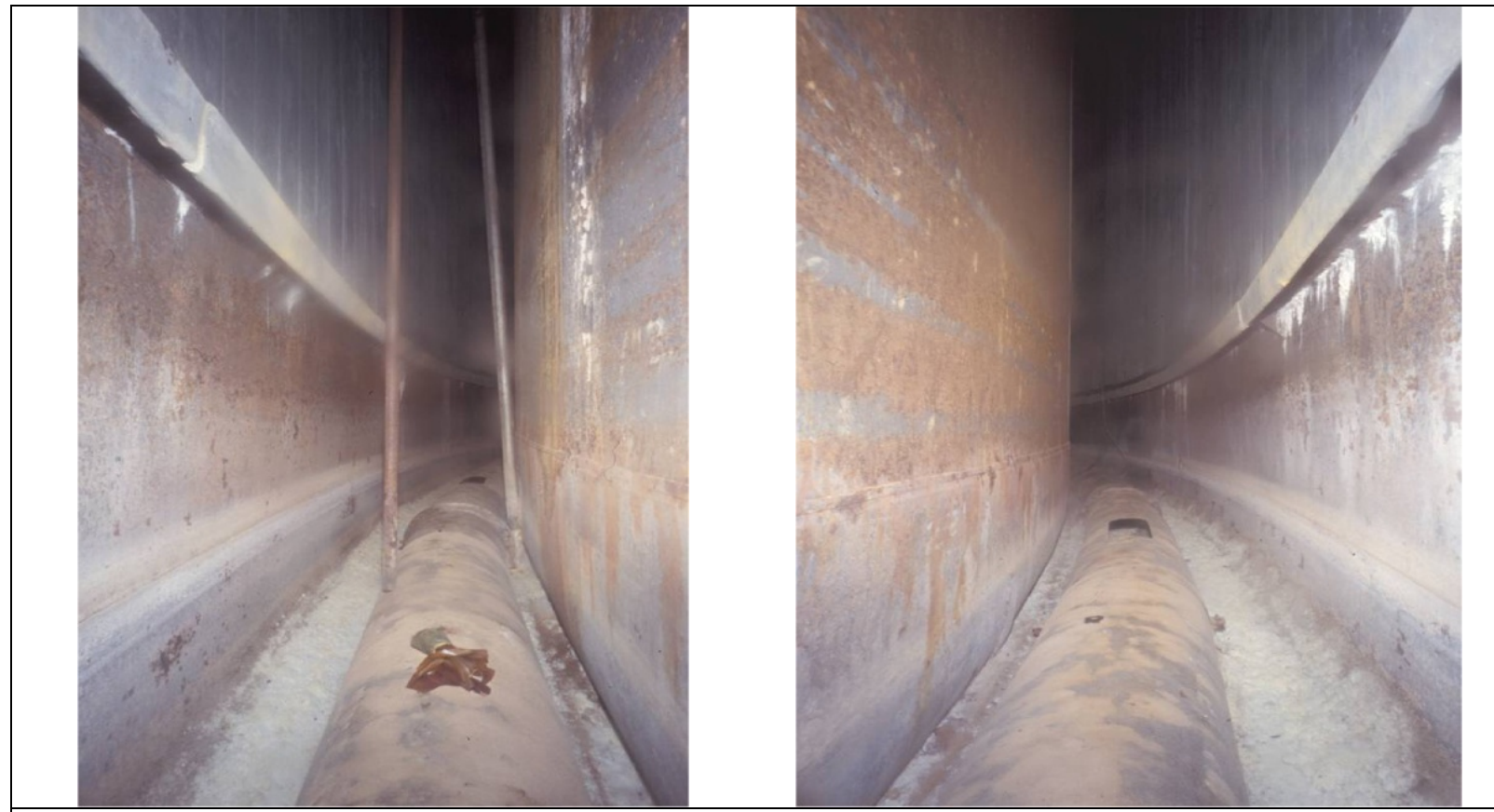

Figure 2.2 Photographs from IP-35 of the Tank 16H Annulus

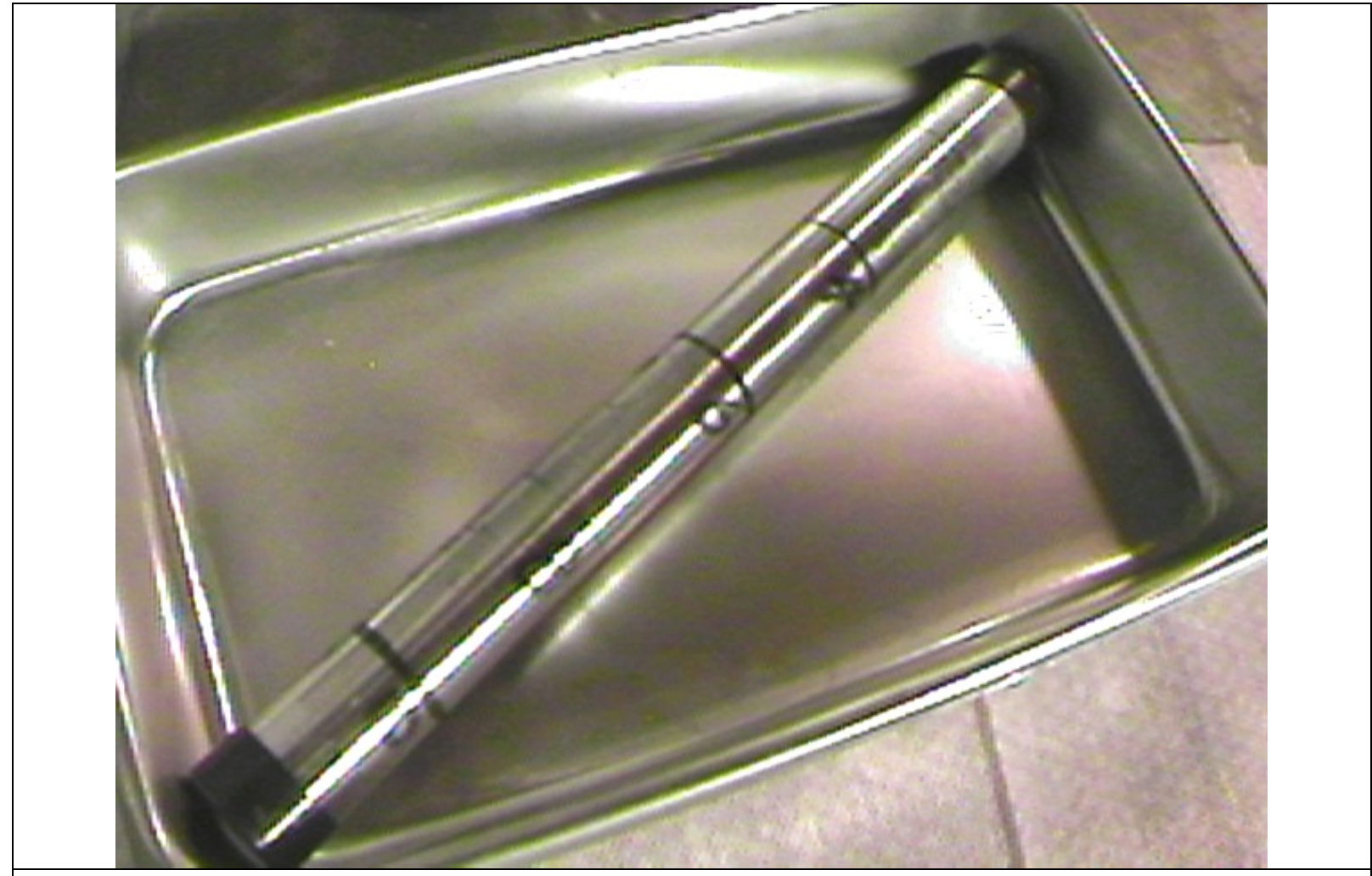

Figure 2.3 Photograph of the Core Sampler Used for Sampling the Tank 16H Annulus 


\subsection{SAMPLE DESCRIPTION}

At SRNL, the core samples were loaded into the Shielded Cells and the plastic end caps removed. Using a long spatula, the material in each core sample was scraped into glass jars with each 1"-2" section going into a separate jar. The material in all three core samples was firmly packed into the core sample tube but was easily removed using the spatula. No free liquid was present in any of the core samples.

The core sample from IP-118 (HTF-16-06-106) contained approximately 6” of material. The material appeared to be slightly moist and the top 1"-2" was slightly darker in color than the bottom sections removed from the sampler. Figure 2.4 provides photographs of the four sections removed from the core sample.

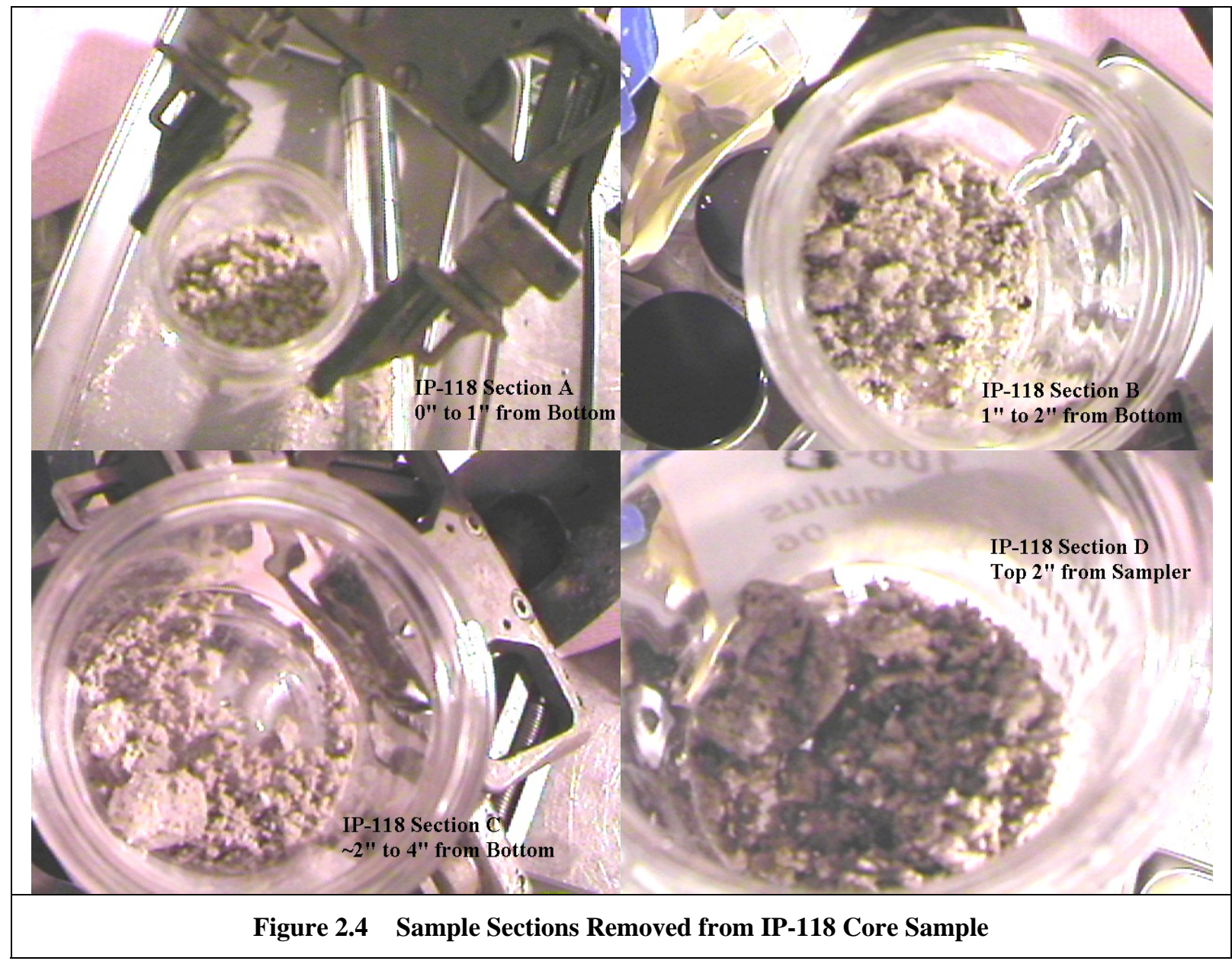


The core sample obtained from inside the dehumidification duct at IP-35 (HTF-16-06-104) contained approximately 3" of material. The material appeared drier and more brittle than the material obtained from IP-118. The color and texture of the material appeared consistent throughout the sample. Figure 2.5 provides photographs of the two sections removed from the core sample.

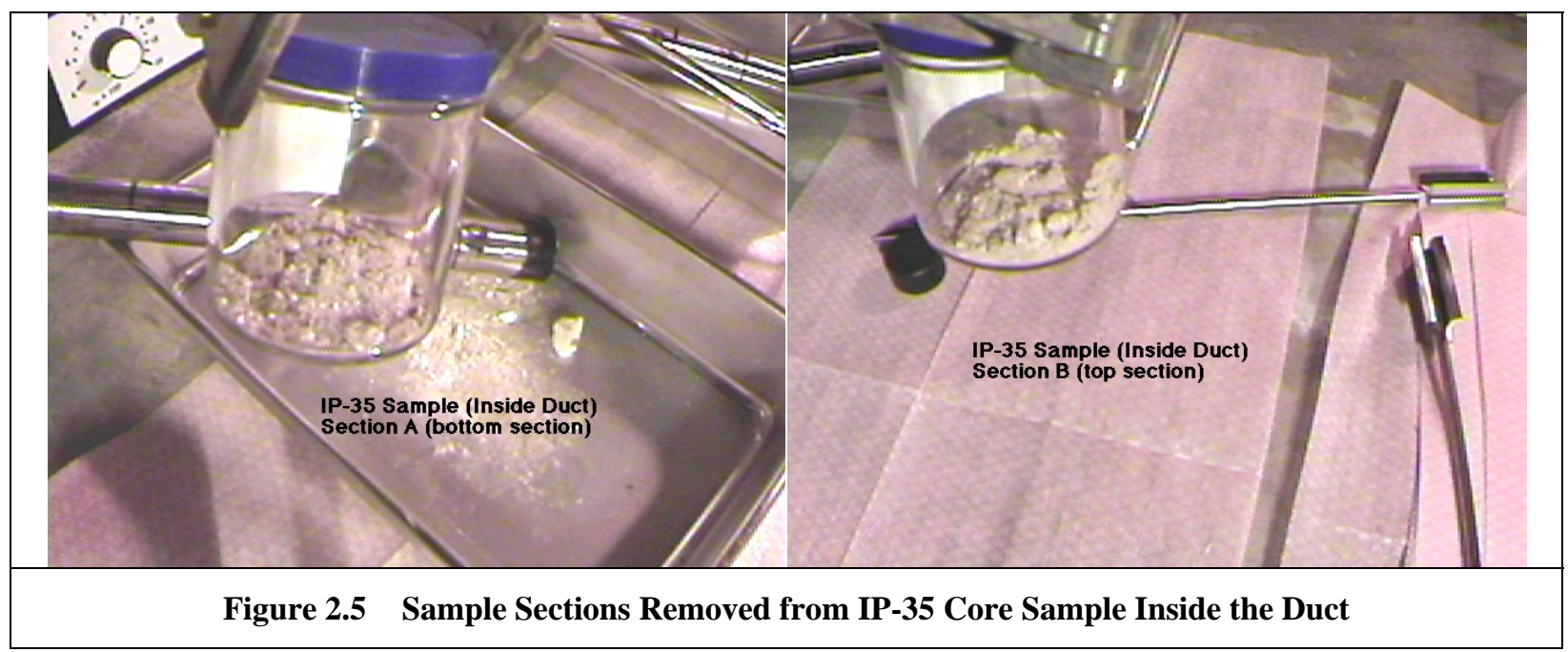

The core sample obtained from outside the dehumidification duct at IP-35 (HTF-16-06-105) contained approximately 5” of material. This material also appeared drier and more brittle than the material obtained from IP-118. The middle section of the sample (Section C) contained material that appeared much whiter in color than the other sections of the sample. Figure 2.6 provides photographs of the five sections removed from the core sample. 


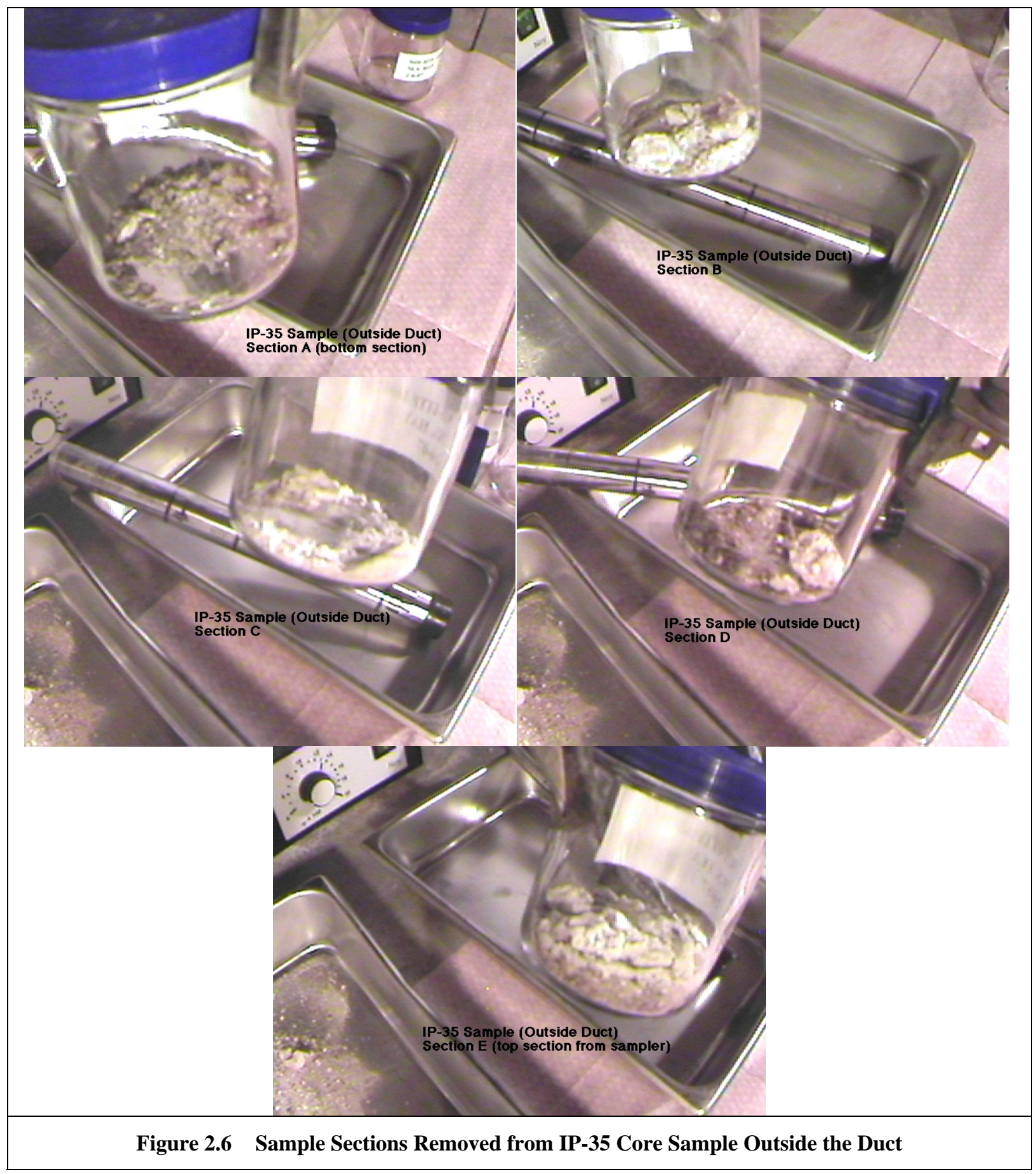


WSRC-STI-2008-00203, REV. 0

\subsection{SAMPLE PREPARATION FOR ANALYSIS}

Samples of the solids isolated from each of the core samples were prepared for X-Ray Diffraction (XRD), Contained Scanning Electron Microscopy (CSEM), and dissolved for elemental analysis. To reduce cost, a composite of each core sample was prepared by taking equal weights from each of the sections isolated from that sample. Additionally, XRD and CSEM analysis were conducted on a sample of the top and bottom sections isolated from the IP-118 sample (HTF-16-06-106) and Section C of the IP-35 sample from outside the dehumidification duct (HTF-16-06-105). For each composite sample the solids were broken up and thoroughly mixed prior to preparing samples for analysis.

The CSEM samples were prepared using a mounting stem fitted with a piece of double sided tape that was tapped into the powder and subsequently packaged for transfer to Analytical Development (AD). A small amount of the solids from each sample were placed in a poly bottle and removed for XRD analysis. All CSEM and XRD analyses were conducted in duplicate.

A portion of the solids from each sample composite were dried in an oven at $100{ }^{\circ} \mathrm{C}$ overnight. The wt \% solids for the three annulus samples ranged from $83 \%$ to $91 \%$ indicating very little water was present in the samples. The dried solids were prepared for analysis using two fusion methods. An aqua regia digestion was not conducted since the samples were known from previous analysis of Tank $16 \mathrm{H}$ annulus samples to contain sodium aluminum silicates that do not dissolve well in aqua regia. ${ }^{6,7}$ The standard fusion with sodium peroxide followed by uptake in hydrochloric acid was supplemented with a fusion with cesium hydroxide. The cesium hydroxide allows determination of sodium content not obtainable from the sodium peroxide fusion. The digested solids from each method were diluted to reduce activity and allow removal from the Shielded Cells. All sample preparations were conducted in duplicate. Duplicate digestions of a glass standard containing many of the elements found in tank samples were prepared concurrently with the sample digestions. Table 2-1 lists the composition of the Analytical Reference Glass-1 glass standard. ${ }^{8}$ A blank was prepared concurrently with the sample preparations consisting of the digestion reagents using the same manipulations and dilutions conducted on the sample.

A water contact of the solids from each sample composite (undried) was also conducted to allow analysis of water-soluble species. The water contacts were conducted by placing a $\sim 0.5$ g of solids (undried) into a $50 \mathrm{~mL}$ of de-ionized water for 24 hours at ambient temperature $\left(\sim 20^{\circ} \mathrm{C}\right)$. The mixture was filtered through a $0.45 \mu$ nylon filter and submitted for analysis. All of the water contact samples were prepared in duplicate and included a blank. Complete dissolution of the solids by the water was not observed with any of the samples. 
Table 2-1. Composition of the Analytical Reference Glass-1 Standard.

\begin{tabular}{|l|c|c|}
\hline Element & Wt $\%$ in Glass & mg/kg in Glass \\
\hline $\mathrm{Al}$ & $2.50 \%$ & $2.50 \mathrm{E}+04$ \\
\hline $\mathrm{B}$ & $2.69 \%$ & $2.69 \mathrm{E}+04$ \\
\hline $\mathrm{Ba}$ & $0.079 \%$ & $7.90 \mathrm{E}+02$ \\
\hline $\mathrm{Ca}$ & $1.02 \%$ & $1.02 \mathrm{E}+04$ \\
\hline $\mathrm{Cr}$ & $0.064 \%$ & $6.40 \mathrm{E}+02$ \\
\hline $\mathrm{Cu}$ & $0.003 \%$ & $3.0 \mathrm{E}+01$ \\
\hline $\mathrm{Fe}$ & $9.79 \%$ & $9.79 \mathrm{E}+04$ \\
\hline $\mathrm{K}$ & $2.26 \%$ & $2.26 \mathrm{E}+04$ \\
\hline $\mathrm{Li}$ & $1.49 \%$ & $1.49 \mathrm{E}+04$ \\
\hline $\mathrm{Mg}$ & $0.52 \%$ & $5.2 \mathrm{E}+03$ \\
\hline $\mathrm{Mn}$ & $1.46 \%$ & $1.46 \mathrm{E}+04$ \\
\hline $\mathrm{Na}$ & $8.52 \%$ & $8.52 \mathrm{E}+04$ \\
\hline $\mathrm{Ni}$ & $0.83 \%$ & $8.3 \mathrm{E}+03$ \\
\hline $\mathrm{P}$ & $0.11 \%$ & $1.1 \mathrm{E}+03$ \\
\hline $\mathrm{Si}$ & $22.4 \%$ & $2.24 \mathrm{E}+05$ \\
\hline $\mathrm{Sr}$ & $0.003 \%$ & $3.0 \mathrm{E}+01$ \\
\hline $\mathrm{Ti}$ & $0.69 \%$ & $6.9 \mathrm{E}+03$ \\
\hline $\mathrm{Zn}$ & $0.016 \%$ & $1.6 \mathrm{E}+02$ \\
\hline $\mathrm{Zr}$ & $0.096 \%$ & $9.6 \mathrm{E}+02$ \\
\hline
\end{tabular}


WSRC-STI-2008-00203, REV. 0

\subsection{RESULTS OF THE SAMPLE CHARACTERIZATION}

\subsection{GENERAL INFORMATION}

Tables 3-2 through 3-12 provide the chemical composition of the Tank $16 \mathrm{H}$ annulus samples received at SRNL. Figures 3.1 through 3.5 provide the results of the XRD analysis of the samples. Figures 3.6 through 3.64 show the results of the CSEM analysis. Analytical results for samples use units of $\mathrm{mg} / \mathrm{kg}$ of dried solids. (Note: To convert values in $\mathrm{mg} / \mathrm{kg}$ to a weight percent solids basis, divide by $1 \mathrm{E}+04$.)

The tables include the results of all replicates, blanks, and the average of the two glass standards. In tables containing data for digested solids samples, the data for the blank has been converted to a dried solids basis to allow direct comparison to the sample data as a quality indicator. The data for the blank were converted to a dried solids basis by dividing the concentrations measured in the blank by the target weight of solids used in the digestion ( $\sim 0.250 \mathrm{~g}$ in most cases). For waste tank sample characterization, an uncertainty of approximately $+/-15 \%$ has been found to be the normal range for the combined sampling and analytical uncertainty. ${ }^{9}$ For the Tank $16 \mathrm{H}$ samples, the percent relative standard deviation (\%RSD) presented in the tables only includes the uncertainty associated with subsampling in the Shielded Cells and the uncertainty of the analytical method. It should be noted that the samples represent a small amount of material from three small areas in the tank annulus.

The data tables also indicate the analytical method used to measure each analyte. Table 3-1 shows the abbreviations used for each analytical method:

Table 3-1. Abbreviations for Analytical Methods used in Data Tables

\begin{tabular}{|l|c|}
\hline Analytical Method & $\begin{array}{c}\text { Abbreviation } \\
\text { in Tables }\end{array}$ \\
\hline Inductively Coupled Plasma-Emission Spectroscopy & IE \\
\hline Inductively Coupled Plasma-Mass Spectrometry & IM \\
\hline Ion Chromatography & IC \\
\hline Titration for Free Hydroxide & TH \\
\hline Total Inorganic Carbon & TIC \\
\hline Separation/Alpha Spec. & SA \\
\hline
\end{tabular}


WSRC-STI-2008-00203, REV. 0

\subsection{RESULTS OF THE ANALYSIS OF SOLIDS FROM IP-35 SAMPLE FROM INSIDE THE DEHUMIDIFICATION DUCT (HTF-16-06-104)}

Tables 3-4, 3-5, and 3-10 show the results of the analysis of the solids in the IP-35 sample from inside the dehumidification duct (HTF-16-06-104). The results of the analysis of the digested solids from the sample (Tables 3-4 and 3-5) indicate that $\mathrm{Na}, \mathrm{Al}, \mathrm{Fe}, \mathrm{Si}$, and S represent the major elements present in the solids. The digested solids results show reasonable agreement between the two digestion methods for the major elements. Some of the \%RSD's for both digestion methods appear high. In most cases, the higher variability between the two duplicate samples results from concentrations close to the detection limits of the method. The heterogeneous nature of the material and associated difficulties in subsampling the solids may also contribute to the higher \%RSD's. For both digestion methods the results of the ARG-1 glass standards show close agreement with the expected concentrations for the standard. In Table 3-5 the detectable levels of Ag and Ca appear to result from contamination present in the blank. The total uranium measured by IE shows a $40 \%$ higher result than the IM measurement. The IE will sometimes show a high bias due to spectral interferences. The ${ }^{239 / 240} \mathrm{Pu}$ from the SA method and from the IM method show reasonable agreement with a difference of $19 \%$.

The results of the water contact with the solids from the sample (Table 3-10) indicate the solids contain significant amounts of the soluble anions $\mathrm{NO}_{2}^{-}, \mathrm{NO}_{3}{ }^{-}, \mathrm{CO}_{3}{ }^{2-}$, and $\mathrm{SO}_{4}{ }^{2-}$ with $\mathrm{Na}$ being the main soluble cation. The anion/cation charge balance for the solution analyzed from the water contact is quite good with a difference of only $1 \%$. The soluble sulfate concentration in the water contact measured by IC shows reasonable agreement with the sulfur concentration measured by IE (20\% difference). The soluble sodium concentration of the water contact shows a $12 \%$ higher concentration than the total sodium measured in the cesium hydroxide fusion (Table 3-4).

Figure 3.1 shows the results of the XRD analysis of the sample. AD identified the following phases present in the XRD of the sample along with the estimated percentage for each phase:

$50 \%$ Trona (Hydrated Sodium Bicarbonate) $-\mathrm{Na}_{3} \mathrm{H}\left(\mathrm{CO}_{3}\right)_{2} \cdot 2 \mathrm{H}_{2} \mathrm{O}$

$30 \%$ Sodium Nitrate $-\mathrm{NaNO}_{3}$

$10 \%$ Sodium Nitrite $-\mathrm{NaNO}_{2}$

$5 \% \quad$ Bayerite $-\mathrm{Al}(\mathrm{OH})_{3}$

$5 \% \quad$ Gibbsite $-\mathrm{Al}(\mathrm{OH})_{3}$

Figures 3.6 through 3.18 provide the CSEM micrographs and associated Energy Dispersive X-Ray (EDX) spectra for the sample. Figures 3.6 and 3.7 indicate a bulk composition consistent with the chemical analysis showing the presence of $\mathrm{Na}, \mathrm{Al}, \mathrm{Fe}, \mathrm{Si}$, and $\mathrm{S}$ along with Ni. Figure 3.8 through 3.11 at higher magnification show areas of high Si content (possibly sand) and areas of high $\mathrm{Na}$ and $\mathrm{O}$ content. The spot composed of $\mathrm{Na}$ and $\mathrm{O}$ may result from hydrated sodium bicarbonate (Trona) or the sodium nitrate or sodium nitrite identified in the XRD. The EDX generally does not detect carbon or nitrogen due to attenuation from the carbon coating applied to the sample and the boron nitride window on the instrument. Appendix A contains additional CSEM micrographs and EDX spectra for the duplicate of the sample. 
WSRC-STI-2008-00203, REV. 0

\subsection{RESULTS OF THE ANALYSIS OF SOLIDS FROM IP-35 SAMPLE FROM OUTSIDE THE DEHUMIDIFICATION DUCT (HTF-16-06-105)}

Tables 3-6, 3-7, and 3-11 show the results of the analysis of the solids in the IP-35 sample from outside the dehumidification duct (HTF-16-06-105). The results of the analysis of the digested solids from the sample (Tables 3-6 and 3-7) indicate that $\mathrm{Na}, \mathrm{Si}, \mathrm{Al}, \mathrm{Fe}$, and $\mathrm{S}$ represent the major elements present in the solids. The digested solids results show reasonable agreement between the two digestion methods for the major elements. Some of the \%RSD's for both digestion methods appear high for the same reasons described in the previous section. For both digestion methods the results of the ARG glass standards show close agreement with the expected concentrations for the standard. In Table 3-7 the detectable level of $\mathrm{K}$ appears to result from contamination present in the blank. The total uranium measured by IE shows a $29 \%$ higher result than the IM measurement. The IE will sometimes show a high bias due to spectral interferences. The ${ }^{239 / 240} \mathrm{Pu}$ from the SA method and from the IM method show reasonable agreement with a difference of $19 \%$.

The results of the water contact with the solids from the sample (Table 3-11) indicate the solids contain significant amounts of the soluble anions $\mathrm{NO}_{2}^{-}, \mathrm{NO}_{3}{ }^{-}, \mathrm{CO}_{3}{ }^{2-}$, and $\mathrm{SO}_{4}{ }^{2-}$ with $\mathrm{Na}$ being the main soluble cation. The anion/cation charge balance for the solution analyzed from the water contact appears low on anionic charges with a difference of 55\%. The soluble sulfate concentration in the water contact measured by IC shows reasonable agreement with the sulfur concentration measured by IE (16\% difference). The soluble sodium concentration of the water contact shows a $20 \%$ higher concentration than the total sodium measured in the cesium hydroxide fusion (Table 3-6).

Figures 3.2 and 3.3 shows the results of the XRD analysis of the composite sample and Section $C$ of the sample. Section $C$ of the sample contained solids that appeared whiter in color than the rest of the sample sections collected. AD identified the following phases present in the XRD of the composite sample along with the estimated percentage for each phase:

$70 \%$ Trona (Hydrated Sodium Bicarbonate) $-\mathrm{Na}_{3} \mathrm{H}\left(\mathrm{CO}_{3}\right)_{2} .2 \mathrm{H}_{2} \mathrm{O}$

$10 \%$ Sodium Aluminum Nitrate Silicate Hydrate- $\mathrm{Na}_{3}\left(\mathrm{Al}_{6} \mathrm{Si}_{6} \mathrm{O}_{24}\right)\left(\mathrm{NO}_{3}\right)_{2} \cdot 4 \mathrm{H}_{2} \mathrm{O}$

$10 \%$ Quartz-SiO 2

$10 \%$ Sodium Aluminum Silicate $-\mathrm{NaO} \cdot \mathrm{Al}_{2} \mathrm{O}_{3} \cdot \mathrm{SiO}_{2}$

AD identified the following phases present in the XRD of the Section C sample along with the estimated percentage for each phase:

$50 \% \quad$ Nitratine (Sodium Nitrate) $-\mathrm{NaNO}_{3}$

$30 \%$ Sodium Nitrite $-\mathrm{NaNO}_{2}$

$20 \%$ Trona (Hydrated Sodium Bicarbonate) $-\mathrm{Na}_{3} \mathrm{H}\left(\mathrm{CO}_{3}\right)_{2} \cdot 2 \mathrm{H}_{2} \mathrm{O}$ 
Figures 3.19 through 3.29 provide the CSEM micrographs and associated EDX spectra for the sample. Figures 3.19 and 3.20 indicate a bulk composition consistent with the chemical analysis showing the presence of Na, Si, Al, Fe, and S along with Ni. Figure 3.23 show areas of high $\mathrm{Na}, \mathrm{Al}$, and Si content.

Figures 3.30 through 3.41 provide the CSEM micrographs and associated EDX spectra for Section $\mathrm{C}$ of the sample. Figures 3.30 and 3.31 indicate a bulk composition consistent with the chemical analysis showing the presence of $\mathrm{Na}, \mathrm{Si}, \mathrm{Al}, \mathrm{Fe}$, and $\mathrm{S}$. Appendix A contains additional CSEM micrographs and EDX spectra for the duplicate of the samples.

\subsection{RESULTS OF THE ANALYSIS OF SOLIDS FROM IP-118 SAMPLE (HTF-16- 06-106)}

Tables 3-8, 3-9, and 3-12 show the results of the analysis of the solids in the IP-118 sample (HTF-16-06-106). The results of the analysis of the digested solids from the sample (Tables 3-8 and 3-9) indicate that $\mathrm{Na}, \mathrm{Si}, \mathrm{Al}, \mathrm{Fe}$, and $\mathrm{S}$ represent the major elements present in the solids. The digested solids results show reasonable agreement between the two digestion methods for the major elements. Some of the \%RSD’s for both digestion methods appear high for the same reasons described in the previous section. For both digestion methods the results of the ARG-1 glass standards show close agreement with the expected concentrations for the standard. However the blank for the peroxide fusion data in Table 3-9 shows elevated

concentrations of Ag, Al, Ca, Fe, and Mo. The ${ }^{239 / 240} \mathrm{Pu}$ from the SA method and from the IM method show reasonable agreement with a difference of $19 \%$.

The results of the water contact with the solids from the sample (Table 3-12) indicate the solids contain significant amounts of the soluble anions $\mathrm{NO}_{2}{ }^{-}, \mathrm{NO}_{3}{ }^{-}, \mathrm{CO}_{3}{ }^{2-}$, and $\mathrm{SO}_{4}{ }^{2-}$ but less than other two annulus samples. The anion/cation charge balance for the solution analyzed from the water contact appears low on anionic charges with a difference of $27 \%$. The soluble sulfate concentration in the water contact measured by IC shows reasonable agreement with the sulfur concentration measured by IE (20\% difference). The soluble sodium concentration of the water contact shows a $31 \%$ lower concentration than the total sodium measured in the cesium hydroxide fusion (Table 3-8).

Figures 3.4 and 3.5 shows the results of the XRD analysis of the sample. Material from the top (Section D) and the bottom (Section A) of the sample were analyzed. AD identified the following phases present in the XRD of the material from the top of the sampler (Section $\mathrm{D}$ ) along with the estimated percentage for each phase:

95\% Sodium Aluminum Nitrate Silicate Hydrate- $\mathrm{Na}_{3}\left(\mathrm{Al}_{6} \mathrm{Si}_{6} \mathrm{O}_{24}\right)\left(\mathrm{NO}_{3}\right)_{2} \cdot 4 \mathrm{H}_{2} \mathrm{O}$

$5 \% \quad$ Muscovite-3T - $(\mathrm{K}, \mathrm{Na})(\mathrm{Al}, \mathrm{Mg}, \mathrm{Fe})\left(\mathrm{Si}_{1.3} \mathrm{O}_{0.9}\right) \mathrm{O}_{10}(\mathrm{OH})_{2}$ 
AD identified the following phases present in the XRD of the bottom (Section A) of the sample along with the estimated percentage for each phase:

$75 \%$ Sodium Aluminum Nitrate Silicate Hydrate- $\mathrm{Na}_{3}\left(\mathrm{Al}_{6} \mathrm{Si}_{6} \mathrm{O}_{24}\right)\left(\mathrm{NO}_{3}\right)_{2} .4 \mathrm{H}_{2} \mathrm{O}$

$10 \%$ Sodium Nitrite $-\mathrm{NaNO}_{2}$

$5 \% \quad$ Muscovite-3T (K, Na)(Al, Mg, $\mathrm{Fe})\left(\mathrm{Si}_{1.3} \mathrm{O}_{0.9}\right) \mathrm{O}_{10}(\mathrm{OH})_{2}$

$5 \%$ Quartz-SiO 2

$5 \%$ Nitratine (Sodium Nitrate) $-\mathrm{NaNO}_{3}$

Figures 3.42 through 3.64 provide the CSEM micrographs and associated EDX spectra for the material from the top (Section D) and the bottom (Section A) of the sample. For both sections of the sample the spectra appear consistent with the chemical and XRD analysis showing $\mathrm{Na}, \mathrm{Al}, \mathrm{Si}$, and $\mathrm{O}$ as the main constituents. Appendix A contains additional CSEM micrographs and EDX spectra for the duplicate of the samples. 
Table 3-4. Composition of the Cesium Hydroxide Fusion Dissolution of Solids from Sample HTF-16-06-104

\begin{tabular}{|c|c|c|c|c|c|c|c|}
\hline Analyte (Method) & $\begin{array}{c}\text { 1st } \\
\text { Replicate } \\
(\mathrm{mg} / \mathrm{kg})\end{array}$ & $\begin{array}{c}\text { 2nd } \\
\text { Replicate } \\
(\mathrm{mg} / \mathrm{kg})\end{array}$ & $\begin{array}{c}\text { Average } \\
\text { (mg/kg) }\end{array}$ & \%RSD & $\begin{array}{c}\text { Blank } \\
\text { (mg/kg) }\end{array}$ & $\begin{array}{c}\text { Avg Analyzed } \\
\text { Glass Std } \\
\text { (mg/kg) } \\
\end{array}$ & $\begin{array}{c}\begin{array}{c}\text { Glass Std } \\
\text { Composition } \\
(\mathrm{mg} / \mathrm{kg})\end{array} \\
\end{array}$ \\
\hline Ag (IE) & $<1.8 \mathrm{E}+02$ & $<1.7 \mathrm{E}+02$ & - & - & $<2.7 \mathrm{E}+02$ & $9.03 E+02$ & - \\
\hline $\mathrm{Al}$ (IE) & $8.39 E+04$ & $9.41 \mathrm{E}+04$ & $8.90 \mathrm{E}+04$ & $8.1 \%$ & $6.12 \mathrm{E}+02$ & $2.37 \mathrm{E}+04$ & $2.50 \mathrm{E}+04$ \\
\hline B (IE) & $<4.1 \mathrm{E}+02$ & $<3.9 \mathrm{E}+02$ & - & - & $<3.8 \mathrm{E}+02$ & $2.39 \mathrm{E}+04$ & $2.69 \mathrm{E}+04$ \\
\hline $\mathrm{Ba}$ (IE) & $3.39 \mathrm{E}+02$ & $6.18 \mathrm{E}+02$ & $4.79 \mathrm{E}+02$ & $41 \%$ & $<2.1 \mathrm{E}+02$ & $8.15 E+02$ & $7.90 \mathrm{E}+02$ \\
\hline Ca (IE) & $6.39 \mathrm{E}+02$ & $1.25 \mathrm{E}+03$ & $9.45 \mathrm{E}+02$ & $46 \%$ & $<2.3 \mathrm{E}+02$ & $9.04 \mathrm{E}+03$ & $1.02 \mathrm{E}+04$ \\
\hline Cd (IE) & $<8.3 \mathrm{E}+01$ & $<7.8 \mathrm{E}+01$ & - & - & $<7.6 \mathrm{E}+01$ & $<8.7 \mathrm{E}+01$ & - \\
\hline Ce (IE) & $<5.5 \mathrm{E}+03$ & $<5.2 \mathrm{E}+03$ & - & - & $<5.1 \mathrm{E}+03$ & $<5.8 \mathrm{E}+03$ & - \\
\hline $\mathrm{Cr}$ (IE) & $<4.3 \mathrm{E}+02$ & $<4.0 \mathrm{E}+02$ & - & - & $<3.9 \mathrm{E}+02$ & $7.91 \mathrm{E}+02$ & $6.40 \mathrm{E}+02$ \\
\hline $\mathrm{Cu}$ (IE) & $1.15 \mathrm{E}+02$ & $2.53 \mathrm{E}+02$ & $1.84 \mathrm{E}+02$ & $53 \%$ & $<2.7 \mathrm{E}+01$ & $<3.1 \mathrm{E}+01$ & $3.00 \mathrm{E}+01$ \\
\hline Fe (IE) & $2.06 \mathrm{E}+04$ & $3.37 \mathrm{E}+04$ & $2.72 \mathrm{E}+04$ & $34 \%$ & $6.64 \mathrm{E}+02$ & $9.64 \mathrm{E}+04$ & $9.79 \mathrm{E}+04$ \\
\hline Gd (IE) & $<2.4 \mathrm{E}+02$ & $<2.3 \mathrm{E}+02$ & - & - & $<2.2 \mathrm{E}+02$ & $<2.5 \mathrm{E}+02$ & - \\
\hline K (IE) & $<6.8 \mathrm{E}+03$ & $<6.3 \mathrm{E}+03$ & - & - & $<6.3 \mathrm{E}+03$ & $2.15 \mathrm{E}+04$ & $2.26 \mathrm{E}+04$ \\
\hline La (IE) & $<1.2 \mathrm{E}+03$ & $<1.1 \mathrm{E}+03$ & - & - & $<1.1 \mathrm{E}+03$ & $<1.2 \mathrm{E}+03$ & - \\
\hline Li (IE) & $<7.4 \mathrm{E}+02$ & $<6.9 \mathrm{E}+02$ & - & - & $<6.8 \mathrm{E}+02$ & $1.55 \mathrm{E}+04$ & $1.49 \mathrm{E}+04$ \\
\hline Mg (IE) & $3.15 E+02$ & $7.59 \mathrm{E}+02$ & $5.37 \mathrm{E}+02$ & $58 \%$ & $<1.3 \mathrm{E}+02$ & $4.85 \mathrm{E}+03$ & $5.20 \mathrm{E}+03$ \\
\hline Mn (IE) & $3.02 E+02$ & $6.95 E+02$ & $4.99 \mathrm{E}+02$ & $56 \%$ & $<1.7 \mathrm{E}+01$ & $1.39 E+04$ & $1.46 \mathrm{E}+04$ \\
\hline Mo (IE) & $<2.2 \mathrm{E}+03$ & $<2.0 \mathrm{E}+03$ & - & - & $<2.0 \mathrm{E}+03$ & $<2.3 \mathrm{E}+03$ & - \\
\hline $\mathrm{Na}$ (IE) & $1.86 \mathrm{E}+05$ & $1.91 \mathrm{E}+05$ & $1.89 \mathrm{E}+05$ & $1.9 \%$ & $8.00 \mathrm{E}+02$ & $7.97 \mathrm{E}+04$ & $8.52 E+04$ \\
\hline
\end{tabular}

* Single Value Divide $\mathrm{mg} / \mathrm{kg}$ values by $1 \mathrm{E}+04$ to convert to wt \% basis 
WSRC-STI-2008-00203, REV. 0

Table 3-4. Composition of the Cesium Hydroxide Fusion Dissolution of Solids from Sample HTF-16-06-104 (continued)

\begin{tabular}{|c|c|c|c|c|c|c|c|}
\hline Analyte (Method) & $\begin{array}{c}\text { 1st } \\
\text { Replicate } \\
\text { (mg/kg) }\end{array}$ & $\begin{array}{c}\text { 2nd } \\
\text { Replicate } \\
\text { (mg/kg) }\end{array}$ & $\begin{array}{c}\text { Average } \\
\text { (mg/kg) }\end{array}$ & \%RSD & $\begin{array}{c}\text { Blank } \\
\text { (mg/kg) }\end{array}$ & $\begin{array}{c}\text { Avg Analyzed } \\
\text { Glass Std } \\
\text { (mg/kg) }\end{array}$ & \begin{tabular}{|c|} 
Glass Std \\
Composition \\
(mg/kg)
\end{tabular} \\
\hline $\mathrm{Ni}$ (IE) & $<6.2 \mathrm{E}+02$ & $<5.8 \mathrm{E}+02$ & - & - & $<5.7 \mathrm{E}+02$ & $7.51 \mathrm{E}+03$ & $8.27 \mathrm{E}+03$ \\
\hline $\mathrm{P}$ (IE) & $<4.0 \mathrm{E}+03$ & $<3.8 \mathrm{E}+03$ & - & - & $<3.7 \mathrm{E}+03$ & $<4.3 \mathrm{E}+03$ & $1.10 \mathrm{E}+03$ \\
\hline $\mathrm{Pb}$ (IE) & $<5.3 \mathrm{E}+03$ & $<4.9 \mathrm{E}+03$ & - & - & $<4.9 \mathrm{E}+03$ & $<5.5 \mathrm{E}+03$ & - \\
\hline S (IE) & $3.31 \mathrm{E}+03$ & $3.85 E+03$ & $3.58 \mathrm{E}+03$ & $11 \%$ & $<1.3 \mathrm{E}+03$ & $<1.5 \mathrm{E}+03$ & - \\
\hline Sb (IE) & $<1.3 \mathrm{E}+03$ & $<1.2 \mathrm{E}+03$ & - & - & $<1.2 \mathrm{E}+03$ & $<1.4 \mathrm{E}+03$ & - \\
\hline Si (IE) & $1.85 \mathrm{E}+04$ & $2.49 \mathrm{E}+04$ & $2.17 \mathrm{E}+04$ & $21 \%$ & $<2.3 \mathrm{E}+02$ & $2.13 \mathrm{E}+05$ & $2.24 \mathrm{E}+05$ \\
\hline Sn (IE) & $<1.2 \mathrm{E}+04$ & $<1.1 \mathrm{E}+04$ & - & - & $<1.1 \mathrm{E}+04$ & $<1.3 \mathrm{E}+04$ & - \\
\hline Sr (IE) & $<7.6 \mathrm{E}+02$ & $<7.1 \mathrm{E}+02$ & - & - & $<7.0 \mathrm{E}+02$ & $1.60 \mathrm{E}+03$ & $3.00 \mathrm{E}+01$ \\
\hline Ti (IE) & $<4.1 \mathrm{E}+01$ & $7.49 \mathrm{E}+01$ & $7.49 \mathrm{E}+01^{*}$ & - & $<3.8 \mathrm{E}+01$ & $6.51 \mathrm{E}+03$ & $6.90 \mathrm{E}+03$ \\
\hline U (IE) & $7.85 \mathrm{E}+02$ & $1.08 \mathrm{E}+03$ & $9.33 \mathrm{E}+02$ & $22 \%$ & $<4.5 \mathrm{E}+02$ & $<5.3 \mathrm{E}+02$ & - \\
\hline V (IE) & $<1.5 \mathrm{E}+02$ & $<1.4 \mathrm{E}+02$ & - & - & $<1.4 \mathrm{E}+02$ & $<1.6 \mathrm{E}+02$ & - \\
\hline Zn (IE) & $6.23 E+02$ & $6.94 \mathrm{E}+02$ & $6.59 \mathrm{E}+02$ & $7.6 \%$ & $<3.0 \mathrm{E}+02$ & $<3.4 \mathrm{E}+02$ & $1.60 \mathrm{E}+02$ \\
\hline
\end{tabular}

* Single Value

Divide $\mathrm{mg} / \mathrm{kg}$ values by $1 \mathrm{E}+04$ to convert to wt $\%$ basis 
WSRC-STI-2008-00203, REV. 0

Table 3-5. Composition of the Sodium Peroxide Fusion Dissolution of Solids from Sample HTF-16-06-104

\begin{tabular}{|c|c|c|c|c|c|c|c|}
\hline Analyte (Method) & $\begin{array}{c}\text { 1st } \\
\text { Replicate } \\
(\mathrm{mg} / \mathrm{kg})\end{array}$ & $\begin{array}{c}\text { 2nd } \\
\text { Replicate } \\
(\mathrm{mg} / \mathrm{kg})\end{array}$ & $\begin{array}{c}\text { Average } \\
\text { (mg/kg) }\end{array}$ & \%RSD & $\begin{array}{c}\text { Blank } \\
\text { (mg/kg) }\end{array}$ & \begin{tabular}{|c} 
Avg Analyzed \\
Glass Std \\
(mg/kg)
\end{tabular} & \begin{tabular}{|c|} 
Glass Std \\
Composition \\
(mg/kg)
\end{tabular} \\
\hline Ag (IE) & $2.74 \mathrm{E}+02$ & $4.12 \mathrm{E}+02$ & $3.43 E+02$ & $28 \%$ & $7.63 \mathrm{E}+02$ & $2.72 \mathrm{E}+02$ & - \\
\hline Al (IE) & $7.81 \mathrm{E}+04$ & $1.01 \mathrm{E}+05$ & $8.96 \mathrm{E}+04$ & $18 \%$ & $1.04 \mathrm{E}+03$ & $2.52 E+04$ & $2.50 \mathrm{E}+04$ \\
\hline B (IE) & $<3.4 \mathrm{E}+02$ & $<4.1 \mathrm{E}+02$ & - & - & $<3.8 \mathrm{E}+02$ & $2.47 \mathrm{E}+04$ & $2.69 \mathrm{E}+04$ \\
\hline $\mathrm{Ba}$ (IE) & $<2.9 \mathrm{E}+02$ & $4.50 \mathrm{E}+02$ & $4.50 \mathrm{E}+02 *$ & - & $<2.1 \mathrm{E}+02$ & $8.26 \mathrm{E}+02$ & $7.90 \mathrm{E}+02$ \\
\hline Ca (IE) & $1.91 \mathrm{E}+03$ & $2.39 \mathrm{E}+03$ & $2.15 \mathrm{E}+03$ & $16 \%$ & $1.48 \mathrm{E}+03$ & $1.14 \mathrm{E}+04$ & $1.02 \mathrm{E}+04$ \\
\hline Cd (IE) & $<6.9 \mathrm{E}+01$ & $<8.3 \mathrm{E}+01$ & - & - & $<7.7 \mathrm{E}+01$ & $<8.0 \mathrm{E}+01$ & - \\
\hline Ce (IE) & $<4.6 \mathrm{E}+03$ & $<5.5 \mathrm{E}+03$ & - & - & $<5.1 \mathrm{E}+03$ & $5.30 \mathrm{E}+03$ & - \\
\hline Cr (IE) & $<3.5 \mathrm{E}+02$ & $<4.2 \mathrm{E}+02$ & - & - & $<3.9 \mathrm{E}+02$ & $4.42 \mathrm{E}+02$ & $6.40 \mathrm{E}+02$ \\
\hline $\mathrm{Cu}$ (IE) & $1.65 E+02$ & $2.35 \mathrm{E}+02$ & $2.00 \mathrm{E}+02$ & $25 \%$ & $<2.7 \mathrm{E}+01$ & $<2.8 \mathrm{E}+01$ & $3.00 \mathrm{E}+01$ \\
\hline Fe (IE) & $1.73 E+04$ & $3.20 \mathrm{E}+04$ & $2.46 \mathrm{E}+04$ & $42 \%$ & $<5.8 \mathrm{E}+01$ & $9.85 E+04$ & $9.79 E+04$ \\
\hline Gd (IE) & $<2.0 \mathrm{E}+02$ & $<2.4 \mathrm{E}+02$ & - & - & $<2.2 \mathrm{E}+02$ & $<2.3 \mathrm{E}+02$ & - \\
\hline $\mathrm{K}$ (IE) & $<5.6 \mathrm{E}+03$ & $<6.8 \mathrm{E}+03$ & - & - & $<6.3 \mathrm{E}+03$ & $2.41 \mathrm{E}+04$ & $2.26 \mathrm{E}+04$ \\
\hline La (IE) & $<9.6 \mathrm{E}+02$ & $<1.2 \mathrm{E}+03$ & - & - & $<1.1 \mathrm{E}+03$ & $<1.1 \mathrm{E}+03$ & - \\
\hline $\mathrm{Li}$ (IE) & $<6.2 \mathrm{E}+02$ & $<7.4 \mathrm{E}+02$ & - & - & $<6.9 \mathrm{E}+02$ & $1.79 E+04$ & $1.49 \mathrm{E}+04$ \\
\hline $\mathrm{Mg}$ (IE) & $3.61 \mathrm{E}+02$ & $5.40 \mathrm{E}+02$ & $4.50 \mathrm{E}+02$ & $28 \%$ & $<1.3 \mathrm{E}+02$ & $4.92 \mathrm{E}+03$ & $5.20 \mathrm{E}+03$ \\
\hline Mn (IE) & $2.01 \mathrm{E}+02$ & $3.41 \mathrm{E}+02$ & $2.71 \mathrm{E}+02$ & $36 \%$ & $<1.7 \mathrm{E}+01$ & $1.45 \mathrm{E}+04$ & $1.46 \mathrm{E}+04$ \\
\hline Mo (IE) & $<1.8 \mathrm{E}+03$ & $<2.2 \mathrm{E}+03$ & - & - & $<2.0 \mathrm{E}+03$ & $2.32 \mathrm{E}+03$ & - \\
\hline
\end{tabular}

* Single Value

Divide $\mathrm{mg} / \mathrm{kg}$ values by $1 \mathrm{E}+04$ to convert to wt \% basis 
WSRC-STI-2008-00203, REV. 0

Table 3-5. Composition of the Sodium Peroxide Fusion Dissolution of Solids from Sample HTF-16-06-104 (continued)

\begin{tabular}{|c|c|c|c|c|c|c|c|}
\hline Analyte (Method) & $\begin{array}{c}\text { 1st } \\
\text { Replicate } \\
(\mathrm{mg} / \mathrm{kg})\end{array}$ & $\begin{array}{c}\text { 2nd } \\
\text { Replicate } \\
\text { (mg/kg) } \\
\end{array}$ & $\begin{array}{c}\text { Average } \\
\text { (mg/kg) }\end{array}$ & \%RSD & $\begin{array}{c}\text { Blank } \\
\text { (mg/kg) }\end{array}$ & \begin{tabular}{|c} 
Avg Analyzed \\
Glass Std \\
(mg/kg)
\end{tabular} & \begin{tabular}{|c|} 
Glass Std \\
Composition \\
(mg/kg)
\end{tabular} \\
\hline $\mathrm{Ni}$ (IE) & $<5.1 \mathrm{E}+02$ & $<6.1 \mathrm{E}+02$ & - & - & $<5.7 \mathrm{E}+02$ & $7.79 E+03$ & $8.27 \mathrm{E}+03$ \\
\hline $\mathrm{P}$ (IE) & $<3.4 \mathrm{E}+03$ & $<4.0 \mathrm{E}+03$ & - & - & $<3.7 \mathrm{E}+03$ & $<3.9 \mathrm{E}+03$ & $1.10 \mathrm{E}+03$ \\
\hline $\mathrm{Pb}$ (IE) & $<4.4 \mathrm{E}+03$ & $<5.2 \mathrm{E}+03$ & - & - & $<4.9 \mathrm{E}+03$ & $<5.1 \mathrm{E}+03$ & - \\
\hline S (IE) & $4.20 \mathrm{E}+03$ & $3.51 \mathrm{E}+03$ & $3.86 \mathrm{E}+03$ & $13 \%$ & $<1.3 \mathrm{E}+03$ & $<1.3 \mathrm{E}+03$ & - \\
\hline Sb (IE) & $<1.1 \mathrm{E}+03$ & $1.56 \mathrm{E}+03$ & $1.56 \mathrm{E}+03^{*}$ & - & $<1.2 \mathrm{E}+03$ & $1.51 \mathrm{E}+03$ & - \\
\hline Si (IE) & $2.06 \mathrm{E}+04$ & $2.49 \mathrm{E}+04$ & $2.27 \mathrm{E}+04$ & $13 \%$ & $<2.3 \mathrm{E}+02$ & $2.29 \mathrm{E}+05$ & $2.24 \mathrm{E}+05$ \\
\hline Sn (IE) & $<9.9 \mathrm{E}+03$ & $<1.2 \mathrm{E}+04$ & - & - & $<1.1 \mathrm{E}+04$ & $1.16 \mathrm{E}+04$ & - \\
\hline Sr (IE) & $<6.3 \mathrm{E}+02$ & $<7.6 \mathrm{E}+02$ & - & - & $<7.0 \mathrm{E}+02$ & $2.14 \mathrm{E}+03$ & $3.00 \mathrm{E}+01$ \\
\hline Ti (IE) & $3.96 \mathrm{E}+01$ & $4.96 \mathrm{E}+01$ & $4.46 \mathrm{E}+01$ & $16 \%$ & $<3.8 \mathrm{E}+01$ & $6.80 \mathrm{E}+03$ & $6.90 \mathrm{E}+03$ \\
\hline U (IE) & $8.24 \mathrm{E}+02$ & $1.05 \mathrm{E}+03$ & $9.36 \mathrm{E}+02$ & $17 \%$ & $<4.5 \mathrm{E}+02$ & $5.19 \mathrm{E}+02$ & - \\
\hline V (IE) & $<1.3 \mathrm{E}+02$ & $<1.5 \mathrm{E}+02$ & - & - & $<1.4 \mathrm{E}+02$ & $<1.5 \mathrm{E}+02$ & - \\
\hline Zn (IE) & $<2.7 \mathrm{E}+02$ & $6.23 E+02$ & $6.23 \mathrm{E}+02 *$ & - & $<3.0 \mathrm{E}+02$ & $<3.1 \mathrm{E}+02$ & $1.60 \mathrm{E}+02$ \\
\hline${ }^{233} \mathrm{U}$ (IM) & $<1.3 \mathrm{E}+00$ & $<1.6 \mathrm{E}+00$ & - & - & $<1.5 \mathrm{E}+00$ & $<1.6 \mathrm{E}+00$ & - \\
\hline${ }^{234} \mathrm{U}$ (IM) & $<1.8 \mathrm{E}+00$ & $<2.2 \mathrm{E}+00$ & - & - & $<2.0 \mathrm{E}+00$ & $<2.1 \mathrm{E}+00$ & - \\
\hline${ }^{235} \mathrm{U}$ (IM) & $2.09 \mathrm{E}+01$ & $2.58 \mathrm{E}+01$ & $2.33 \mathrm{E}+01$ & $15 \%$ & $<1.0 \mathrm{E}+00$ & $<1.0 \mathrm{E}+00$ & - \\
\hline${ }^{236} \mathrm{U}$ (IM) & $2.35 \mathrm{E}+00$ & $2.69 \mathrm{E}+00$ & $2.52 \mathrm{E}+00$ & $9.7 \%$ & $<2.5 \mathrm{E}+00$ & $<2.6 \mathrm{E}+00$ & - \\
\hline${ }^{238} \mathrm{U}$ (IM) & $5.62 \mathrm{E}+02$ & $7.08 \mathrm{E}+02$ & $6.35 \mathrm{E}+02$ & $16 \%$ & $7.93 \mathrm{E}+00$ & $9.34 \mathrm{E}+00$ & - \\
\hline U total (IM) & $5.88 \mathrm{E}+02$ & $7.40 \mathrm{E}+02$ & $6.64 \mathrm{E}+02$ & $16 \%$ & $1.49 \mathrm{E}+01$ & $1.66 \mathrm{E}+01$ & - \\
\hline
\end{tabular}

* Single Value

Divide $\mathrm{mg} / \mathrm{kg}$ values by $1 \mathrm{E}+04$ to convert to wt \% basis 
WSRC-STI-2008-00203, REV. 0

Table 3-5. Composition of the Sodium Peroxide Fusion Dissolution of Solids from Sample HTF-16-06-104 (continued)

\begin{tabular}{|l|c|c|c|c|c|c|c|}
\hline Analyte (Method) & $\begin{array}{c}\text { 1st } \\
\text { Replicate } \\
\text { (mCi/Kg) }\end{array}$ & $\begin{array}{c}\text { 2nd } \\
\text { Replicate } \\
\text { (mCi/Kg) }\end{array}$ & $\begin{array}{c}\text { Average } \\
\text { (mCi/Kg) }\end{array}$ & \%RSD & $\begin{array}{c}\text { Blank } \\
\text { (mCi/Kg) }\end{array}$ & $\begin{array}{c}\text { Avg Analyzed } \\
\text { Glass Std } \\
\text { (mCi/Kg) }\end{array}$ & $\begin{array}{c}\text { Glass Std } \\
\text { Composition } \\
\text { (mCi/Kg) }\end{array}$ \\
\hline${ }^{238} \mathrm{Pu}(\mathrm{SA})$ & $6.81 \mathrm{E}+00$ & $9.76 \mathrm{E}+00$ & $8.28 \mathrm{E}+00$ & $25 \%$ & $<3.2 \mathrm{E}-03$ & $<2.1 \mathrm{E}-01$ & - \\
\hline${ }^{239 / 240} \mathrm{Pu}(\mathrm{SA})$ & $1.28 \mathrm{E}+00$ & $1.83 \mathrm{E}+00$ & $1.56 \mathrm{E}+00$ & $25 \%$ & $<6.2 \mathrm{E}-03$ & $<2.2 \mathrm{E}-02$ & - \\
\hline${ }^{241} \mathrm{Pu}(\mathrm{SA})$ & $3.61 \mathrm{E}+00$ & $5.00 \mathrm{E}+00$ & $4.30 \mathrm{E}+00$ & $23 \%$ & $<1.7 \mathrm{E}-01$ & $<1.9 \mathrm{E}-01$ & - \\
\hline${ }^{99} \mathrm{Tc}(\mathrm{IM})$ & $3.99 \mathrm{E}-01$ & $6.89 \mathrm{E}-01$ & $5.44 \mathrm{E}-01$ & $38 \%$ & $2.55 \mathrm{E}-02$ & $2.65 \mathrm{E}-02$ & - \\
\hline${ }^{237} \mathrm{~Np}(\mathrm{IM})$ & $5.86 \mathrm{E}-03$ & $6.66 \mathrm{E}-03$ & $6.26 \mathrm{E}-03$ & $9.0 \%$ & $<7.0 \mathrm{E}-04$ & $<7.3 \mathrm{E}-04$ & - \\
\hline${ }^{239} \mathrm{Pu}(\mathrm{IM})$ & $1.01 \mathrm{E}+00$ & $1.34 \mathrm{E}+00$ & $1.17 \mathrm{E}+00$ & $20 \%$ & $<6.1 \mathrm{E}-02$ & $<6.4 \mathrm{E}-02$ & - \\
\hline${ }^{240} \mathrm{Pu}(\mathrm{IM})$ & $5.67 \mathrm{E}-01$ & $7.88 \mathrm{E}-01$ & $6.77 \mathrm{E}-01$ & $23 \%$ & $<2.3 \mathrm{E}-01$ & $<2.3 \mathrm{E}-01$ & - \\
\hline${ }^{242} \mathrm{Pu}(\mathrm{IM})$ & $<1.2 \mathrm{E}-02$ & $<1.5 \mathrm{E}-02$ & - & - & $<1.4 \mathrm{E}-02$ & $<1.4 \mathrm{E}-02$ & - \\
\hline
\end{tabular}

* Single Value 
Table 3-6. Composition of the Cesium Hydroxide Fusion Dissolution of Solids from Sample HTF-16-06-105

\begin{tabular}{|c|c|c|c|c|c|c|c|}
\hline Analyte (Method) & $\begin{array}{c}\text { 1st } \\
\text { Replicate } \\
(\mathrm{mg} / \mathrm{kg})\end{array}$ & $\begin{array}{c}\text { 2nd } \\
\text { Replicate } \\
(\mathrm{mg} / \mathrm{kg})\end{array}$ & $\begin{array}{c}\text { Average } \\
\text { (mg/kg) }\end{array}$ & \%RSD & $\begin{array}{c}\text { Blank } \\
\text { (mg/kg) }\end{array}$ & $\begin{array}{c}\text { Avg Analyzed } \\
\text { Glass Std } \\
\text { (mg/kg) }\end{array}$ & \begin{tabular}{|c|} 
Glass Std \\
Composition \\
$(\mathrm{mg} / \mathrm{kg})$
\end{tabular} \\
\hline Ag (IE) & $<1.8 \mathrm{E}+02$ & $<1.9 \mathrm{E}+02$ & - & - & $4.96 \mathrm{E}+02$ & $8.27 \mathrm{E}+02$ & - \\
\hline $\mathrm{Al}$ (IE) & $6.10 \mathrm{E}+04$ & $4.78 \mathrm{E}+04$ & $5.44 \mathrm{E}+04$ & $17 \%$ & $6.28 \mathrm{E}+02$ & $2.21 \mathrm{E}+04$ & $2.50 \mathrm{E}+04$ \\
\hline B (IE) & $<4.1 \mathrm{E}+02$ & $<4.3 \mathrm{E}+02$ & - & - & $<3.8 \mathrm{E}+02$ & $2.28 \mathrm{E}+04$ & $2.69 \mathrm{E}+04$ \\
\hline $\mathrm{Ba}$ (IE) & $4.34 \mathrm{E}+02$ & $3.19 \mathrm{E}+02$ & $3.77 \mathrm{E}+02$ & $22 \%$ & $<2.1 \mathrm{E}+02$ & $7.94 \mathrm{E}+02$ & $7.90 \mathrm{E}+02$ \\
\hline Ca (IE) & $1.04 \mathrm{E}+03$ & $1.27 \mathrm{E}+03$ & $1.16 \mathrm{E}+03$ & $14 \%$ & $<2.3 \mathrm{E}+02$ & $8.58 \mathrm{E}+03$ & $1.02 \mathrm{E}+04$ \\
\hline Cd (IE) & $<8.1 \mathrm{E}+01$ & $<8.5 \mathrm{E}+01$ & - & - & $<7.6 \mathrm{E}+01$ & $<7.9 \mathrm{E}+01$ & - \\
\hline Ce (IE) & $<5.4 \mathrm{E}+03$ & $<5.7 \mathrm{E}+03$ & - & - & $<5.1 \mathrm{E}+03$ & $<5.2 \mathrm{E}+03$ & - \\
\hline $\mathrm{Cr}$ (IE) & $<4.2 \mathrm{E}+02$ & $<4.4 \mathrm{E}+02$ & - & - & $<3.9 \mathrm{E}+02$ & $6.61 \mathrm{E}+02$ & $6.40 \mathrm{E}+02$ \\
\hline $\mathrm{Cu}$ (IE) & $1.52 \mathrm{E}+02$ & $1.01 \mathrm{E}+02$ & $1.27 \mathrm{E}+02$ & $29 \%$ & $<2.7 \mathrm{E}+01$ & $<2.8 \mathrm{E}+01$ & $3.00 \mathrm{E}+01$ \\
\hline Fe (IE) & $2.54 \mathrm{E}+04$ & $2.33 \mathrm{E}+04$ & $2.44 \mathrm{E}+04$ & $6.1 \%$ & $<5.8 \mathrm{E}+01$ & $9.17 \mathrm{E}+04$ & $9.79 \mathrm{E}+04$ \\
\hline Gd (IE) & $<2.4 \mathrm{E}+02$ & $<2.5 \mathrm{E}+02$ & - & - & $<2.2 \mathrm{E}+02$ & $<2.3 \mathrm{E}+02$ & - \\
\hline K (IE) & $<6.7 \mathrm{E}+03$ & $<7.0 \mathrm{E}+03$ & - & - & $<6.3 \mathrm{E}+03$ & $2.08 \mathrm{E}+04$ & $2.26 \mathrm{E}+04$ \\
\hline La (IE) & $<1.1 \mathrm{E}+03$ & $<1.2 \mathrm{E}+03$ & - & - & $<1.1 \mathrm{E}+03$ & $<1.1 \mathrm{E}+03$ & - \\
\hline Li (IE) & $<7.3 \mathrm{E}+02$ & $<7.7 \mathrm{E}+02$ & - & - & $<6.8 \mathrm{E}+02$ & $1.49 \mathrm{E}+04$ & $1.49 \mathrm{E}+04$ \\
\hline Mg (IE) & $4.37 \mathrm{E}+02$ & $2.78 \mathrm{E}+02$ & $3.58 \mathrm{E}+02$ & $31 \%$ & $<1.3 \mathrm{E}+02$ & $4.63 \mathrm{E}+03$ & $5.20 \mathrm{E}+03$ \\
\hline Mn (IE) & $4.11 \mathrm{E}+02$ & $2.46 \mathrm{E}+02$ & $3.29 E+02$ & $36 \%$ & $<1.7 \mathrm{E}+01$ & $1.27 \mathrm{E}+04$ & $1.46 \mathrm{E}+04$ \\
\hline Mo (IE) & $<2.2 \mathrm{E}+03$ & $<2.3 \mathrm{E}+03$ & - & - & $<2.0 \mathrm{E}+03$ & $<2.1 \mathrm{E}+03$ & - \\
\hline $\mathrm{Na}$ (IE) & $1.69 \mathrm{E}+05$ & $2.40 \mathrm{E}+05$ & $2.05 E+05$ & $25 \%$ & $7.40 \mathrm{E}+02$ & $7.28 \mathrm{E}+04$ & $8.52 E+04$ \\
\hline
\end{tabular}

* Single Value $\quad$ Divide $\mathrm{mg} / \mathrm{kg}$ values by $1 \mathrm{E}+04$ to convert to wt \% basis 
WSRC-STI-2008-00203, REV. 0

Table 3-6. Composition of the Cesium Hydroxide Fusion Dissolution of Solids from Sample HTF-16-06-105 (continued)

\begin{tabular}{|c|c|c|c|c|c|c|c|}
\hline Analyte (Method) & $\begin{array}{c}\text { 1st } \\
\text { Replicate } \\
\text { (mg/kg) }\end{array}$ & $\begin{array}{c}\text { 2nd } \\
\text { Replicate } \\
\text { (mg/kg) }\end{array}$ & $\begin{array}{c}\text { Average } \\
\text { (mg/kg) }\end{array}$ & \%RSD & $\begin{array}{c}\text { Blank } \\
\text { (mg/kg) }\end{array}$ & $\begin{array}{c}\text { Avg Analyzed } \\
\text { Glass Std } \\
\text { (mg/kg) }\end{array}$ & \begin{tabular}{|c|} 
Glass Std \\
Composition \\
(mg/kg)
\end{tabular} \\
\hline $\mathrm{Ni}$ (IE) & $<6.1 \mathrm{E}+02$ & $<6.4 \mathrm{E}+02$ & - & - & $<5.7 \mathrm{E}+02$ & $7.16 \mathrm{E}+03$ & $8.27 \mathrm{E}+03$ \\
\hline $\mathrm{P}$ (IE) & $<4.0 \mathrm{E}+03$ & $<4.2 \mathrm{E}+03$ & - & - & $<3.7 \mathrm{E}+03$ & $<3.8 \mathrm{E}+03$ & $1.10 \mathrm{E}+03$ \\
\hline $\mathrm{Pb}$ (IE) & $<5.2 \mathrm{E}+03$ & $<5.4 \mathrm{E}+03$ & - & - & $<4.9 \mathrm{E}+03$ & $<5.0 \mathrm{E}+03$ & - \\
\hline S (IE) & $4.16 \mathrm{E}+03$ & $3.43 E+03$ & $3.80 \mathrm{E}+03$ & $14 \%$ & $<1.3 \mathrm{E}+03$ & $<1.3 \mathrm{E}+03$ & - \\
\hline Sb (IE) & $<1.3 \mathrm{E}+03$ & $<1.3 \mathrm{E}+03$ & - & - & $<1.2 \mathrm{E}+03$ & $<1.2 \mathrm{E}+03$ & - \\
\hline Si (IE) & $1.27 \mathrm{E}+05$ & $1.19 \mathrm{E}+05$ & $1.23 \mathrm{E}+05$ & $4.6 \%$ & $<2.3 \mathrm{E}+02$ & $2.02 \mathrm{E}+05$ & $2.24 \mathrm{E}+05$ \\
\hline Sn (IE) & $<1.2 \mathrm{E}+04$ & $<1.2 \mathrm{E}+04$ & - & - & $<1.1 \mathrm{E}+04$ & $<1.1 \mathrm{E}+04$ & - \\
\hline Sr (IE) & $<7.5 \mathrm{E}+02$ & $<7.8 \mathrm{E}+02$ & - & - & $<7.0 \mathrm{E}+02$ & $1.54 \mathrm{E}+03$ & $3.00 \mathrm{E}+01$ \\
\hline Ti (IE) & $7.38 \mathrm{E}+01$ & $8.17 \mathrm{E}+01$ & $7.78 \mathrm{E}+01$ & $7.2 \%$ & $<3.8 \mathrm{E}+01$ & $6.20 \mathrm{E}+03$ & $6.90 \mathrm{E}+03$ \\
\hline U (IE) & $1.06 \mathrm{E}+03$ & $8.62 \mathrm{E}+02$ & $9.61 \mathrm{E}+02$ & $15 \%$ & $<4.5 \mathrm{E}+02$ & $<4.6 \mathrm{E}+02$ & - \\
\hline V (IE) & $<1.5 \mathrm{E}+02$ & $<1.6 \mathrm{E}+02$ & - & - & $<1.4 \mathrm{E}+02$ & $<1.5 \mathrm{E}+02$ & - \\
\hline Zn (IE) & $6.30 \mathrm{E}+02$ & $7.52 \mathrm{E}+02$ & $6.91 \mathrm{E}+02$ & $12 \%$ & $<3.0 \mathrm{E}+02$ & $<3.1 \mathrm{E}+02$ & $1.60 \mathrm{E}+02$ \\
\hline
\end{tabular}

* Single Value

Divide $\mathrm{mg} / \mathrm{kg}$ values by $1 \mathrm{E}+04$ to convert to wt $\%$ basis 
WSRC-STI-2008-00203, REV. 0

Table 3-7. Composition of the Sodium Peroxide Fusion Dissolution of Solids from Sample HTF-16-06-105

\begin{tabular}{|c|c|c|c|c|c|c|c|}
\hline Analyte (Method) & $\begin{array}{c}\text { 1st } \\
\text { Replicate } \\
(\mathrm{mg} / \mathrm{kg})\end{array}$ & $\begin{array}{c}\text { 2nd } \\
\text { Replicate } \\
(\mathrm{mg} / \mathrm{kg})\end{array}$ & $\begin{array}{c}\text { Average } \\
\text { (mg/kg) }\end{array}$ & \%RSD & $\begin{array}{c}\text { Blank } \\
\text { (mg/kg) }\end{array}$ & \begin{tabular}{|c} 
Avg Analyzed \\
Glass Std \\
(mg/kg)
\end{tabular} & \begin{tabular}{|c|} 
Glass Std \\
Composition \\
(mg/kg)
\end{tabular} \\
\hline Ag (IE) & $<1.6 \mathrm{E}+02$ & $4.06 \mathrm{E}+02$ & $4.06 \mathrm{E}+02 *$ & - & $6.99 \mathrm{E}+02$ & $3.21 \mathrm{E}+02$ & - \\
\hline Al (IE) & $4.80 \mathrm{E}+04$ & $5.59 \mathrm{E}+04$ & $5.20 \mathrm{E}+04$ & $11 \%$ & $1.12 \mathrm{E}+03$ & $2.68 E+04$ & $2.50 \mathrm{E}+04$ \\
\hline B (IE) & $<3.7 \mathrm{E}+02$ & $<3.7 \mathrm{E}+02$ & - & - & $<3.8 \mathrm{E}+02$ & $2.66 \mathrm{E}+04$ & $2.69 \mathrm{E}+04$ \\
\hline $\mathrm{Ba}$ (IE) & $2.43 E+02$ & $4.19 \mathrm{E}+02$ & $3.31 \mathrm{E}+02$ & $38 \%$ & $<2.1 \mathrm{E}+02$ & $9.05 E+02$ & $7.90 \mathrm{E}+02$ \\
\hline Ca (IE) & $1.34 \mathrm{E}+03$ & $2.37 \mathrm{E}+03$ & $1.86 \mathrm{E}+03$ & $39 \%$ & $1.43 \mathrm{E}+03$ & $1.18 \mathrm{E}+04$ & $1.02 \mathrm{E}+04$ \\
\hline Cd (IE) & $<7.4 \mathrm{E}+01$ & $<7.5 \mathrm{E}+01$ & - & - & $<7.7 \mathrm{E}+01$ & $<8.3 \mathrm{E}+01$ & - \\
\hline Ce (IE) & $<4.9 \mathrm{E}+03$ & $<5.0 \mathrm{E}+03$ & - & - & $<5.1 \mathrm{E}+03$ & $<5.5 \mathrm{E}+03$ & - \\
\hline Cr (IE) & $<3.8 \mathrm{E}+02$ & $<3.8 \mathrm{E}+02$ & - & - & $<3.9 \mathrm{E}+02$ & $<4.2 \mathrm{E}+02$ & $6.40 \mathrm{E}+02$ \\
\hline $\mathrm{Cu}$ (IE) & $1.44 \mathrm{E}+02$ & $2.18 \mathrm{E}+02$ & $1.81 \mathrm{E}+02$ & $29 \%$ & $4.10 \mathrm{E}+01$ & $5.88 \mathrm{E}+01$ & $3.00 \mathrm{E}+01$ \\
\hline Fe (IE) & $1.71 \mathrm{E}+04$ & $2.27 E+04$ & $1.99 \mathrm{E}+04$ & $20 \%$ & $1.70 \mathrm{E}+02$ & $9.88 \mathrm{E}+04$ & $9.79 E+04$ \\
\hline Gd (IE) & $<2.2 \mathrm{E}+02$ & $<2.2 \mathrm{E}+02$ & - & - & $<2.2 \mathrm{E}+02$ & $<2.4 \mathrm{E}+02$ & - \\
\hline $\mathrm{K}$ (IE) & $9.02 \mathrm{E}+03$ & $1.61 \mathrm{E}+04$ & $1.26 \mathrm{E}+04$ & $40 \%$ & $1.46 \mathrm{E}+04$ & $4.62 \mathrm{E}+04$ & $2.26 \mathrm{E}+04$ \\
\hline La (IE) & $<1.0 \mathrm{E}+03$ & $<1.0 \mathrm{E}+03$ & - & - & $<1.1 \mathrm{E}+03$ & $<1.2 \mathrm{E}+03$ & - \\
\hline $\mathrm{Li}$ (IE) & $<6.6 \mathrm{E}+02$ & $<6.7 \mathrm{E}+02$ & - & - & $<6.9 \mathrm{E}+02$ & $2.21 \mathrm{E}+04$ & $1.49 \mathrm{E}+04$ \\
\hline $\mathrm{Mg}$ (IE) & $1.42 \mathrm{E}+02$ & $3.20 \mathrm{E}+02$ & $2.31 \mathrm{E}+02$ & $55 \%$ & $<1.3 \mathrm{E}+02$ & $4.74 \mathrm{E}+03$ & $5.20 \mathrm{E}+03$ \\
\hline Mn (IE) & $1.52 \mathrm{E}+02$ & $3.03 E+02$ & $2.27 \mathrm{E}+02$ & $47 \%$ & $<1.7 \mathrm{E}+01$ & $1.45 \mathrm{E}+04$ & $1.46 \mathrm{E}+04$ \\
\hline Mo (IE) & $<1.9 \mathrm{E}+03$ & $<2.6 \mathrm{E}+03$ & - & - & $2.60 \mathrm{E}+03$ & $3.42 \mathrm{E}+03$ & - \\
\hline
\end{tabular}

* Single Value

Divide $\mathrm{mg} / \mathrm{kg}$ values by $1 \mathrm{E}+04$ to convert to wt $\%$ basis 
WSRC-STI-2008-00203, REV. 0

Table 3-7. Composition of the Sodium Peroxide Fusion Dissolution of Solids from Sample HTF-16-06-105 (continued)

\begin{tabular}{|c|c|c|c|c|c|c|c|}
\hline Analyte (Method) & $\begin{array}{c}\text { 1st } \\
\text { Replicate } \\
(\mathrm{mg} / \mathrm{kg})\end{array}$ & $\begin{array}{c}\text { 2nd } \\
\text { Replicate } \\
(\mathrm{mg} / \mathrm{kg})\end{array}$ & $\begin{array}{c}\text { Average } \\
\text { (mg/kg) }\end{array}$ & \%RSD & $\begin{array}{c}\text { Blank } \\
\text { (mg/kg) }\end{array}$ & \begin{tabular}{|c} 
Avg Analyzed \\
Glass Std \\
(mg/kg)
\end{tabular} & \begin{tabular}{|c|} 
Glass Std \\
Composition \\
(mg/kg)
\end{tabular} \\
\hline $\mathrm{Ni}$ (IE) & $<5.5 \mathrm{E}+02$ & $<5.5 \mathrm{E}+02$ & - & - & $<5.7 \mathrm{E}+02$ & $7.87 \mathrm{E}+03$ & $8.27 \mathrm{E}+03$ \\
\hline $\mathrm{P}$ (IE) & $<3.6 \mathrm{E}+03$ & $<3.6 \mathrm{E}+03$ & - & - & $<3.7 \mathrm{E}+03$ & $<4.0 \mathrm{E}+03$ & $1.10 \mathrm{E}+03$ \\
\hline $\mathrm{Pb}$ (IE) & $<4.7 \mathrm{E}+03$ & $<4.7 \mathrm{E}+03$ & - & - & $<4.9 \mathrm{E}+03$ & $<5.2 \mathrm{E}+03$ & - \\
\hline S (IE) & $1.64 \mathrm{E}+03$ & $1.29 \mathrm{E}+03$ & $1.47 \mathrm{E}+03$ & $17 \%$ & $<1.3 \mathrm{E}+03$ & $<1.4 \mathrm{E}+03$ & - \\
\hline Sb (IE) & $<1.2 \mathrm{E}+03$ & $<1.2 \mathrm{E}+03$ & - & - & $<1.2 \mathrm{E}+03$ & $1.58 \mathrm{E}+03$ & - \\
\hline Si (IE) & $9.75 E+04$ & $1.06 \mathrm{E}+05$ & $1.02 \mathrm{E}+05$ & $5.9 \%$ & $5.55 \mathrm{E}+03$ & $2.46 \mathrm{E}+05$ & $2.24 \mathrm{E}+05$ \\
\hline Sn (IE) & $<1.1 \mathrm{E}+04$ & $<1.1 \mathrm{E}+04$ & - & - & $<1.1 \mathrm{E}+04$ & $<1.2 \mathrm{E}+04$ & - \\
\hline Sr (IE) & $<6.8 \mathrm{E}+02$ & $7.65 E+02$ & $7.65 \mathrm{E}+02 *$ & - & $<7.0 \mathrm{E}+02$ & $2.47 \mathrm{E}+03$ & $3.00 \mathrm{E}+01$ \\
\hline Ti (IE) & $7.53 \mathrm{E}+01$ & $2.17 E+02$ & $1.46 \mathrm{E}+02$ & $69 \%$ & $<3.8 \mathrm{E}+01$ & $6.93 \mathrm{E}+03$ & $6.90 \mathrm{E}+03$ \\
\hline U (IE) & $7.17 \mathrm{E}+02$ & $1.04 \mathrm{E}+03$ & $8.79 E+02$ & $26 \%$ & $<4.5 \mathrm{E}+02$ & $7.04 \mathrm{E}+02$ & - \\
\hline V (IE) & $<1.4 \mathrm{E}+02$ & $<1.4 \mathrm{E}+02$ & - & - & $<1.4 \mathrm{E}+02$ & $<1.5 \mathrm{E}+02$ & - \\
\hline Zn (IE) & $5.32 \mathrm{E}+02$ & $6.76 \mathrm{E}+02$ & $6.04 \mathrm{E}+02$ & $17 \%$ & $<3.0 \mathrm{E}+02$ & $<3.2 \mathrm{E}+02$ & $1.60 \mathrm{E}+02$ \\
\hline${ }^{233} \mathrm{U}$ (IM) & $<9.7 \mathrm{E}-01$ & $<9.7 \mathrm{E}-01$ & - & - & $<1.0 \mathrm{E}+00$ & $<1.1 \mathrm{E}+00$ & - \\
\hline${ }^{234} \mathrm{U}$ (IM) & $<1.9 \mathrm{E}+00$ & $<1.9 \mathrm{E}+00$ & - & - & $<2.0 \mathrm{E}+00$ & $<2.2 \mathrm{E}+00$ & - \\
\hline${ }^{235} \mathrm{U}$ (IM) & $1.33 \mathrm{E}+01$ & $2.43 \mathrm{E}+01$ & $1.88 \mathrm{E}+01$ & $42 \%$ & $<1.0 \mathrm{E}+00$ & $<1.1 \mathrm{E}+00$ & - \\
\hline${ }^{236} \mathrm{U}$ (IM) & $1.21 \mathrm{E}+00$ & $3.05 E+00$ & $2.13 E+00$ & $61 \%$ & $<1.0 \mathrm{E}+00$ & $<1.1 \mathrm{E}+00$ & - \\
\hline${ }^{238} \mathrm{U}$ (IM) & $3.61 \mathrm{E}+02$ & $6.96 \mathrm{E}+02$ & $5.28 \mathrm{E}+02$ & $45 \%$ & $<5.5 \mathrm{E}+00$ & $9.24 \mathrm{E}+00$ & - \\
\hline U total (IM) & $3.76 \mathrm{E}+02$ & $7.23 E+02$ & $5.49 \mathrm{E}+02$ & $45 \%$ & $<1.1 \mathrm{E}+01$ & $9.24 \mathrm{E}+00$ & - \\
\hline
\end{tabular}

* Single Value

Divide $\mathrm{mg} / \mathrm{kg}$ values by $1 \mathrm{E}+04$ to convert to wt $\%$ basis 
WSRC-STI-2008-00203, REV. 0

Table 3-7. Composition of the Sodium Peroxide Fusion Dissolution of Solids from Sample HTF-16-06-105 (continued)

\begin{tabular}{|l|c|c|c|c|c|c|c|}
\hline & $\begin{array}{c}\text { 1st } \\
\text { Replicate } \\
\text { AnCi/Kg) }\end{array}$ & $\begin{array}{c}\text { 2nd } \\
\text { Replicate } \\
\text { (mCi/Kg) }\end{array}$ & $\begin{array}{c}\text { Average } \\
\text { (mCi/Kg) }\end{array}$ & \%RSD & $\begin{array}{c}\text { Blank } \\
\text { (mCi/Kg) }\end{array}$ & $\begin{array}{c}\text { Avg Analyzed } \\
\text { Glass Std } \\
\text { (mCi/Kg) }\end{array}$ & $\begin{array}{c}\text { Glass Std } \\
\text { Composition } \\
\text { (mCi/Kg) }\end{array}$ \\
\hline${ }^{238} \mathrm{Pu}$ (SA) & $3.66 \mathrm{E}+00$ & $6.67 \mathrm{E}+00$ & $5.16 \mathrm{E}+00$ & $41 \%$ & $1.14 \mathrm{E}-02$ & $5.13 \mathrm{E}-03$ & - \\
\hline${ }^{239 / 240} \mathrm{Pu}(\mathrm{SA})$ & $6.31 \mathrm{E}-01$ & $1.24 \mathrm{E}+00$ & $9.35 \mathrm{E}-01$ & $46 \%$ & $8.83 \mathrm{E}-03$ & $<5.1 \mathrm{E}-03$ & - \\
\hline${ }^{241} \mathrm{Pu}(\mathrm{SA})$ & $<1.8 \mathrm{E}+00$ & $<3.1 \mathrm{E}+00$ & - & $38 \%$ & $<6.3 \mathrm{E}-02$ & $<1.3 \mathrm{E}-01$ & - \\
\hline${ }^{99} \mathrm{Tc}(\mathrm{IM})$ & $1.20 \mathrm{E}+00$ & $1.18 \mathrm{E}+00$ & $1.19 \mathrm{E}+00$ & $1.7 \%$ & $<5.9 \mathrm{E}-02$ & $<6.4 \mathrm{E}-02$ & - \\
\hline${ }^{237} \mathrm{~Np}(\mathrm{IM})$ & $3.20 \mathrm{E}-03$ & $6.97 \mathrm{E}-03$ & $5.08 \mathrm{E}-03$ & $53 \%$ & $<1.4 \mathrm{E}-03$ & $<1.5 \mathrm{E}-03$ & - \\
\hline${ }^{239} \mathrm{Pu}(\mathrm{IM})$ & $4.59 \mathrm{E}-01$ & $1.02 \mathrm{E}+00$ & $7.39 \mathrm{E}-01$ & $53 \%$ & $<1.2 \mathrm{E}-01$ & $<1.3 \mathrm{E}-01$ & - \\
\hline${ }^{240} \mathrm{Pu}(\mathrm{IM})$ & $4.77 \mathrm{E}-01$ & $5.52 \mathrm{E}-01$ & $5.15 \mathrm{E}-01$ & $10 \%$ & $<4.5 \mathrm{E}-01$ & $<4.9 \mathrm{E}-01$ & - \\
\hline${ }^{242} \mathrm{Pu}(\mathrm{IM})$ & $<3.8 \mathrm{E}-03$ & $<3.8 \mathrm{E}-03$ & - & - & $<3.9 \mathrm{E}-03$ & $<4.2 \mathrm{E}-03$ & - \\
\hline
\end{tabular}

* Single Value 
WSRC-STI-2008-00203, REV. 0

Table 3-8. Composition of the Cesium Hydroxide Fusion Dissolution of Solids from Sample HTF-16-06-106

\begin{tabular}{|c|c|c|c|c|c|c|c|}
\hline Analyte (Method) & $\begin{array}{c}\text { 1st } \\
\text { Replicate } \\
(\mathrm{mg} / \mathrm{kg})\end{array}$ & $\begin{array}{c}\text { 2nd } \\
\text { Replicate } \\
(\mathrm{mg} / \mathrm{kg})\end{array}$ & $\begin{array}{c}\text { Average } \\
\text { (mg/kg) }\end{array}$ & \%RSD & $\begin{array}{c}\text { Blank } \\
\text { (mg/kg) }\end{array}$ & $\begin{array}{c}\text { Avg Analyzed } \\
\text { Glass Std } \\
\text { (mg/kg) } \\
\end{array}$ & $\begin{array}{c}\begin{array}{c}\text { Glass Std } \\
\text { Composition } \\
(\mathrm{mg} / \mathrm{kg})\end{array} \\
\end{array}$ \\
\hline Ag (IE) & $<1.7 \mathrm{E}+02$ & $<1.8 \mathrm{E}+02$ & - & - & $3.99 \mathrm{E}+02$ & $8.92 \mathrm{E}+02$ & - \\
\hline $\mathrm{Al}$ (IE) & $9.04 \mathrm{E}+04$ & $1.10 \mathrm{E}+05$ & $1.00 \mathrm{E}+05$ & $14 \%$ & $5.32 \mathrm{E}+02$ & $2.42 E+04$ & $2.50 \mathrm{E}+04$ \\
\hline B (IE) & $<3.8 \mathrm{E}+02$ & $<4.2 \mathrm{E}+02$ & - & - & $<3.8 \mathrm{E}+02$ & $2.42 E+04$ & $2.69 \mathrm{E}+04$ \\
\hline $\mathrm{Ba}$ (IE) & $<2.1 \mathrm{E}+02$ & $<2.3 \mathrm{E}+02$ & - & - & $<2.1 \mathrm{E}+02$ & $8.60 \mathrm{E}+02$ & $7.90 \mathrm{E}+02$ \\
\hline Ca (IE) & $<2.3 \mathrm{E}+02$ & $<2.5 \mathrm{E}+02$ & - & - & $<2.3 \mathrm{E}+02$ & $9.22 \mathrm{E}+03$ & $1.02 \mathrm{E}+04$ \\
\hline Cd (IE) & $<7.7 \mathrm{E}+01$ & $<8.4 \mathrm{E}+01$ & - & - & $<7.6 \mathrm{E}+01$ & $<8.2 \mathrm{E}+01$ & - \\
\hline Ce (IE) & $<5.1 \mathrm{E}+03$ & $<5.6 \mathrm{E}+03$ & - & - & $<5.1 \mathrm{E}+03$ & $<5.4 \mathrm{E}+03$ & - \\
\hline $\mathrm{Cr}$ (IE) & $<4.0 \mathrm{E}+02$ & $<4.3 \mathrm{E}+02$ & - & - & $<3.9 \mathrm{E}+02$ & $<5.5 \mathrm{E}+02$ & $6.40 \mathrm{E}+02$ \\
\hline $\mathrm{Cu}$ (IE) & $<2.7 \mathrm{E}+01$ & $<3.0 \mathrm{E}+01$ & - & - & $<2.7 \mathrm{E}+01$ & $<2.9 \mathrm{E}+01$ & $3.00 \mathrm{E}+01$ \\
\hline Fe (IE) & $1.74 \mathrm{E}+03$ & $2.16 \mathrm{E}+03$ & $1.95 \mathrm{E}+03$ & $15 \%$ & $<5.8 \mathrm{E}+01$ & $9.84 \mathrm{E}+04$ & $9.79 \mathrm{E}+04$ \\
\hline Gd (IE) & $<2.2 \mathrm{E}+02$ & $<2.4 \mathrm{E}+02$ & - & - & $<2.2 \mathrm{E}+02$ & $<2.4 \mathrm{E}+02$ & - \\
\hline K (IE) & $<6.3 \mathrm{E}+03$ & $<6.8 \mathrm{E}+03$ & - & - & $<6.3 \mathrm{E}+03$ & $2.29 E+04$ & $2.26 \mathrm{E}+04$ \\
\hline La (IE) & $<1.1 \mathrm{E}+03$ & $<1.2 \mathrm{E}+03$ & - & - & $<1.1 \mathrm{E}+03$ & $<1.1 \mathrm{E}+03$ & - \\
\hline Li (IE) & $<6.9 \mathrm{E}+02$ & $<7.5 \mathrm{E}+02$ & - & - & $<6.8 \mathrm{E}+02$ & $1.60 \mathrm{E}+04$ & $1.49 \mathrm{E}+04$ \\
\hline Mg (IE) & $<1.3 \mathrm{E}+02$ & $<1.4 \mathrm{E}+02$ & - & - & $<1.3 \mathrm{E}+02$ & $5.00 \mathrm{E}+03$ & $5.20 \mathrm{E}+03$ \\
\hline Mn (IE) & $<1.7 \mathrm{E}+01$ & $<1.9 \mathrm{E}+01$ & - & - & $<1.7 \mathrm{E}+01$ & $1.33 \mathrm{E}+04$ & $1.46 \mathrm{E}+04$ \\
\hline Mo (IE) & $<2.0 \mathrm{E}+03$ & $<2.2 \mathrm{E}+03$ & - & - & $<2.0 \mathrm{E}+03$ & $<2.2 \mathrm{E}+03$ & - \\
\hline $\mathrm{Na}$ (IE) & $2.03 E+05$ & $2.20 \mathrm{E}+05$ & $2.12 \mathrm{E}+05$ & $5.7 \%$ & $8.48 \mathrm{E}+02$ & $7.94 \mathrm{E}+04$ & $8.52 E+04$ \\
\hline
\end{tabular}

* Single Value $\quad$ Divide $\mathrm{mg} / \mathrm{kg}$ values by $1 \mathrm{E}+04$ to convert to wt \% basis 
WSRC-STI-2008-00203, REV. 0

Table 3-8. Composition of the Cesium Hydroxide Fusion Dissolution of Solids from Sample HTF-16-06-106 (continued)

\begin{tabular}{|c|c|c|c|c|c|c|c|}
\hline Analyte (Method) & $\begin{array}{c}\text { 1st } \\
\text { Replicate } \\
\text { (mg/kg) }\end{array}$ & $\begin{array}{c}\text { 2nd } \\
\text { Replicate } \\
\text { (mg/kg) }\end{array}$ & $\begin{array}{c}\text { Average } \\
\text { (mg/kg) }\end{array}$ & \%RSD & $\begin{array}{c}\text { Blank } \\
\text { (mg/kg) }\end{array}$ & $\begin{array}{c}\text { Avg Analyzed } \\
\text { Glass Std } \\
\text { (mg/kg) }\end{array}$ & \begin{tabular}{|c|} 
Glass Std \\
Composition \\
(mg/kg)
\end{tabular} \\
\hline $\mathrm{Ni}$ (IE) & $<5.7 \mathrm{E}+02$ & $<6.2 \mathrm{E}+02$ & - & - & $<5.7 \mathrm{E}+02$ & $7.80 \mathrm{E}+03$ & $8.27 \mathrm{E}+03$ \\
\hline $\mathrm{P}$ (IE) & $<3.8 \mathrm{E}+03$ & $<4.1 \mathrm{E}+03$ & - & - & $<3.7 \mathrm{E}+03$ & $<4.0 \mathrm{E}+03$ & $1.10 \mathrm{E}+03$ \\
\hline $\mathrm{Pb}$ (IE) & $<4.9 \mathrm{E}+03$ & $<5.3 \mathrm{E}+03$ & - & - & $<4.9 \mathrm{E}+03$ & $<5.2 \mathrm{E}+03$ & - \\
\hline S (IE) & $<1.3 \mathrm{E}+03$ & $<1.4 \mathrm{E}+03$ & - & - & $<1.3 \mathrm{E}+03$ & $<1.4 \mathrm{E}+03$ & - \\
\hline Sb (IE) & $<1.2 \mathrm{E}+03$ & $<1.3 \mathrm{E}+03$ & - & - & $<1.2 \mathrm{E}+03$ & $<1.3 \mathrm{E}+03$ & - \\
\hline Si (IE) & $1.02 \mathrm{E}+05$ & $1.22 \mathrm{E}+05$ & $1.12 \mathrm{E}+05$ & $13 \%$ & $<2.3 \mathrm{E}+02$ & $2.19 \mathrm{E}+05$ & $2.24 \mathrm{E}+05$ \\
\hline Sn (IE) & $<1.1 \mathrm{E}+04$ & $<1.2 \mathrm{E}+04$ & - & - & $<1.1 \mathrm{E}+04$ & $<1.2 \mathrm{E}+04$ & - \\
\hline Sr (IE) & $<7.0 \mathrm{E}+02$ & $<7.7 \mathrm{E}+02$ & - & - & $<7.0 \mathrm{E}+02$ & $1.68 \mathrm{E}+03$ & $3.00 \mathrm{E}+01$ \\
\hline Ti (IE) & $<3.8 \mathrm{E}+01$ & $<4.2 \mathrm{E}+01$ & - & - & $<3.8 \mathrm{E}+01$ & $6.64 \mathrm{E}+03$ & $6.90 \mathrm{E}+03$ \\
\hline U (IE) & $<4.5 \mathrm{E}+02$ & $<4.9 \mathrm{E}+02$ & - & - & $<4.5 \mathrm{E}+02$ & $5.21 \mathrm{E}+02$ & - \\
\hline V (IE) & $<1.4 \mathrm{E}+02$ & $<1.6 \mathrm{E}+02$ & - & - & $<1.4 \mathrm{E}+02$ & $<1.5 \mathrm{E}+02$ & - \\
\hline Zn (IE) & $<3.0 \mathrm{E}+02$ & $<3.2 \mathrm{E}+02$ & - & - & $<3.0 \mathrm{E}+02$ & $<3.2 \mathrm{E}+02$ & $1.60 \mathrm{E}+02$ \\
\hline
\end{tabular}

* Single Value

Divide $\mathrm{mg} / \mathrm{kg}$ values by $1 \mathrm{E}+04$ to convert to wt $\%$ basis 
WSRC-STI-2008-00203, REV. 0

Table 3-9. Composition of the Sodium Peroxide Fusion Dissolution of Solids from Sample HTF-16-06-106

\begin{tabular}{|c|c|c|c|c|c|c|c|}
\hline Analyte (Method) & $\begin{array}{c}\text { 1st } \\
\text { Replicate } \\
(\mathrm{mg} / \mathrm{kg})\end{array}$ & $\begin{array}{c}\text { 2nd } \\
\text { Replicate } \\
(\mathrm{mg} / \mathrm{kg})\end{array}$ & $\begin{array}{c}\text { Average } \\
\text { (mg/kg) }\end{array}$ & \%RSD & $\begin{array}{c}\text { Blank } \\
\text { (mg/kg) }\end{array}$ & \begin{tabular}{|c} 
Avg Analyzed \\
Glass Std \\
(mg/kg)
\end{tabular} & \begin{tabular}{|c|} 
Glass Std \\
Composition \\
(mg/kg)
\end{tabular} \\
\hline Ag (IE) & $1.48 \mathrm{E}+03$ & $1.44 \mathrm{E}+03$ & $1.46 \mathrm{E}+03$ & $1.7 \%$ & $5.06 \mathrm{E}+03$ & $3.34 \mathrm{E}+03$ & - \\
\hline Al (IE) & $1.13 E+05$ & $1.00 \mathrm{E}+05$ & $1.07 \mathrm{E}+05$ & $8.6 \%$ & $5.93 \mathrm{E}+03$ & $2.99 E+04$ & $2.50 \mathrm{E}+04$ \\
\hline B (IE) & $<3.6 \mathrm{E}+02$ & $<3.4 \mathrm{E}+02$ & - & - & $<3.8 \mathrm{E}+02$ & $2.19 \mathrm{E}+04$ & $2.69 \mathrm{E}+04$ \\
\hline Ba (IE) & $<1.9 \mathrm{E}+02$ & $<1.8 \mathrm{E}+02$ & - & - & $<2.1 \mathrm{E}+02$ & $8.94 \mathrm{E}+02$ & $7.90 \mathrm{E}+02$ \\
\hline Ca (IE) & $1.97 \mathrm{E}+03$ & $2.42 \mathrm{E}+03$ & $2.19 \mathrm{E}+03$ & $14 \%$ & $1.56 \mathrm{E}+03$ & $1.24 \mathrm{E}+04$ & $1.02 \mathrm{E}+04$ \\
\hline Cd (IE) & $<7.2 \mathrm{E}+01$ & $<6.9 \mathrm{E}+01$ & - & - & $<7.7 \mathrm{E}+01$ & $<7.7 \mathrm{E}+01$ & - \\
\hline Ce (IE) & $<4.7 \mathrm{E}+03$ & $<4.6 \mathrm{E}+03$ & - & - & $7.00 \mathrm{E}+03$ & $5.76 \mathrm{E}+03$ & - \\
\hline Cr (IE) & $<3.7 \mathrm{E}+02$ & $<3.5 \mathrm{E}+02$ & - & - & $<3.9 \mathrm{E}+02$ & $6.28 \mathrm{E}+02$ & $6.40 \mathrm{E}+02$ \\
\hline $\mathrm{Cu}$ (IE) & $<2.5 \mathrm{E}+01$ & $<2.4 \mathrm{E}+01$ & - & - & $<2.7 \mathrm{E}+01$ & $<3.6 \mathrm{E}+01$ & $3.00 \mathrm{E}+01$ \\
\hline Fe (IE) & $2.67 \mathrm{E}+03$ & $1.83 E+03$ & $2.25 \mathrm{E}+03$ & $26 \%$ & $5.72 \mathrm{E}+02$ & $1.01 \mathrm{E}+05$ & $9.79 E+04$ \\
\hline Gd (IE) & $<2.1 \mathrm{E}+02$ & $<2.0 \mathrm{E}+02$ & - & - & $<2.2 \mathrm{E}+02$ & $2.30 \mathrm{E}+02$ & - \\
\hline K (IE) & $<5.8 \mathrm{E}+03$ & $<5.6 \mathrm{E}+03$ & - & - & $<6.3 \mathrm{E}+03$ & $2.81 \mathrm{E}+04$ & $2.26 \mathrm{E}+04$ \\
\hline La (IE) & $<9.9 \mathrm{E}+02$ & $<9.6 \mathrm{E}+02$ & - & - & $<1.1 \mathrm{E}+03$ & $9.89 \mathrm{E}+02$ & - \\
\hline Li (IE) & $<6.4 \mathrm{E}+02$ & $<6.1 \mathrm{E}+02$ & - & - & $<6.9 \mathrm{E}+02$ & $1.85 \mathrm{E}+04$ & $1.49 \mathrm{E}+04$ \\
\hline $\mathrm{Mg}$ (IE) & $<1.2 \mathrm{E}+02$ & $<1.1 \mathrm{E}+02$ & - & - & $<1.3 \mathrm{E}+02$ & $4.40 \mathrm{E}+03$ & $5.20 \mathrm{E}+03$ \\
\hline Mn (IE) & $<1.6 \mathrm{E}+01$ & $<1.5 \mathrm{E}+01$ & - & - & $<1.7 \mathrm{E}+01$ & $1.48 \mathrm{E}+04$ & $1.46 \mathrm{E}+04$ \\
\hline Mo (IE) & $2.75 E+03$ & $1.87 \mathrm{E}+03$ & $2.31 \mathrm{E}+03$ & $27 \%$ & $4.17 \mathrm{E}+03$ & $3.91 E+03$ & - \\
\hline
\end{tabular}

* Single Value

Divide $\mathrm{mg} / \mathrm{kg}$ values by $1 \mathrm{E}+04$ to convert to wt $\%$ basis 
WSRC-STI-2008-00203, REV. 0

Table 3-9. Composition of the Sodium Peroxide Fusion Dissolution of Solids from Sample HTF-16-06-106 (continued)

\begin{tabular}{|c|c|c|c|c|c|c|c|}
\hline Analyte (Method) & $\begin{array}{c}\text { 1st } \\
\text { Replicate } \\
(\mathrm{mg} / \mathrm{kg})\end{array}$ & $\begin{array}{c}\text { 2nd } \\
\text { Replicate } \\
(\mathrm{mg} / \mathrm{kg})\end{array}$ & $\begin{array}{c}\text { Average } \\
\text { (mg/kg) }\end{array}$ & \%RSD & $\begin{array}{c}\text { Blank } \\
\text { (mg/kg) }\end{array}$ & \begin{tabular}{|c} 
Avg Analyzed \\
Glass Std \\
(mg/kg)
\end{tabular} & \begin{tabular}{|c|} 
Glass Std \\
Composition \\
(mg/kg)
\end{tabular} \\
\hline $\mathrm{Ni}$ (IE) & $<5.3 \mathrm{E}+02$ & $<5.1 \mathrm{E}+02$ & - & - & $<5.7 \mathrm{E}+02$ & $8.17 \mathrm{E}+03$ & $8.27 \mathrm{E}+03$ \\
\hline $\mathrm{P}$ (IE) & $<3.5 \mathrm{E}+03$ & $<3.3 \mathrm{E}+03$ & - & - & $<3.7 \mathrm{E}+03$ & $<3.2 \mathrm{E}+03$ & $1.10 \mathrm{E}+03$ \\
\hline $\mathrm{Pb}$ (IE) & $<4.5 \mathrm{E}+03$ & $<4.4 \mathrm{E}+03$ & - & - & $<4.9 \mathrm{E}+03$ & $<5.4 \mathrm{E}+03$ & - \\
\hline S (IE) & $1.19 \mathrm{E}+03$ & $1.14 \mathrm{E}+03$ & $1.16 \mathrm{E}+03$ & $3.1 \%$ & $<1.3 \mathrm{E}+03$ & $<1.5 \mathrm{E}+03$ & - \\
\hline Sb (IE) & $<1.1 \mathrm{E}+03$ & $<1.1 \mathrm{E}+03$ & - & - & $2.09 \mathrm{E}+03$ & $1.92 \mathrm{E}+03$ & - \\
\hline Si (IE) & $1.29 \mathrm{E}+05$ & $1.09 \mathrm{E}+05$ & $1.19 \mathrm{E}+05$ & $12 \%$ & $<2.3 \mathrm{E}+02$ & $2.35 \mathrm{E}+05$ & $2.24 \mathrm{E}+05$ \\
\hline Sn (IE) & $<1.0 \mathrm{E}+04$ & $<9.9 \mathrm{E}+03$ & - & - & $<1.1 \mathrm{E}+04$ & $1.26 \mathrm{E}+04$ & - \\
\hline Sr (IE) & $<6.5 \mathrm{E}+02$ & $<6.3 \mathrm{E}+02$ & - & - & $<7.0 \mathrm{E}+02$ & $2.65 \mathrm{E}+03$ & $3.00 \mathrm{E}+01$ \\
\hline Ti (IE) & $<4.2 \mathrm{E}+01$ & $<3.4 \mathrm{E}+01$ & - & - & $8.20 \mathrm{E}+01$ & $7.03 E+03$ & $6.90 \mathrm{E}+03$ \\
\hline U (IE) & $<4.2 \mathrm{E}+02$ & $<4.1 \mathrm{E}+02$ & - & - & $5.21 \mathrm{E}+02$ & $6.38 \mathrm{E}+02$ & - \\
\hline V (IE) & $<1.3 \mathrm{E}+02$ & $<1.3 \mathrm{E}+02$ & - & - & $<1.4 \mathrm{E}+02$ & $1.77 \mathrm{E}+02$ & - \\
\hline Zn (IE) & $<2.8 \mathrm{E}+02$ & $<2.7 \mathrm{E}+02$ & - & - & $<3.0 \mathrm{E}+02$ & $<2.2 \mathrm{E}+02$ & $1.60 \mathrm{E}+02$ \\
\hline${ }^{233} \mathrm{U}$ (IM) & $<5.8 \mathrm{E}-01$ & $<5.6 \mathrm{E}-01$ & - & - & $<6.3 \mathrm{E}-01$ & $<7.0 \mathrm{E}-01$ & - \\
\hline${ }^{234} \mathrm{U}$ (IM) & $<4.6 \mathrm{E}-01$ & $<4.5 \mathrm{E}-01$ & - & - & $<5.0 \mathrm{E}-01$ & $<5.6 \mathrm{E}-01$ & - \\
\hline${ }^{235} \mathrm{U}$ (IM) & $2.53 E+00$ & $2.28 \mathrm{E}+00$ & $2.40 \mathrm{E}+00$ & $7.4 \%$ & $<2.5 \mathrm{E}-01$ & $<2.8 \mathrm{E}-01$ & - \\
\hline${ }^{236} \mathrm{U}$ (IM) & $3.50 \mathrm{E}-01$ & $4.29 \mathrm{E}-01$ & $3.90 \mathrm{E}-01$ & $14 \%$ & $<2.5 \mathrm{E}-01$ & $<2.8 \mathrm{E}-01$ & - \\
\hline${ }^{238} \mathrm{U}$ (IM) & $7.22 \mathrm{E}+01$ & $6.07 \mathrm{E}+01$ & $6.64 \mathrm{E}+01$ & $12 \%$ & $4.60 \mathrm{E}+00$ & $8.18 \mathrm{E}+00$ & - \\
\hline U total (IM) & $7.61 \mathrm{E}+01$ & $6.44 \mathrm{E}+01$ & $7.03 \mathrm{E}+01$ & $12 \%$ & $6.23 E+00$ & $1.00 \mathrm{E}+01$ & - \\
\hline
\end{tabular}

* Single Value

Divide $\mathrm{mg} / \mathrm{kg}$ values by $1 \mathrm{E}+04$ to convert to wt $\%$ basis 
WSRC-STI-2008-00203, REV. 0

Table 3-9. Composition of the Sodium Peroxide Fusion Dissolution of Solids from Sample HTF-16-06-106 (continued)

\begin{tabular}{|l|c|c|c|c|c|c|c|}
\hline Analyte (Method) & $\begin{array}{c}\text { 1st } \\
\text { Replicate } \\
\text { (mCi/Kg) }\end{array}$ & $\begin{array}{c}\text { 2nd } \\
\text { Replicate } \\
\text { (mCi/Kg) }\end{array}$ & $\begin{array}{c}\text { Average } \\
\text { (mCi/Kg) }\end{array}$ & \%RSD & $\begin{array}{c}\text { Blank } \\
\text { (mCi/Kg) }\end{array}$ & $\begin{array}{c}\text { Avg Analyzed } \\
\text { Glass Std } \\
\text { (mCi/Kg) }\end{array}$ & $\begin{array}{c}\text { Glass Std } \\
\text { Composition } \\
\text { (mCi/Kg) }\end{array}$ \\
\hline${ }^{238} \mathrm{Pu}(\mathrm{SA})$ & $6.04 \mathrm{E}-01$ & $5.16 \mathrm{E}-01$ & $5.60 \mathrm{E}-01$ & $11 \%$ & $<7.5 \mathrm{E}-03$ & $<6.0 \mathrm{E}-03$ & - \\
\hline${ }^{239 / 240} \mathrm{Pu}(\mathrm{SA})$ & $1.07 \mathrm{E}-01$ & $9.68 \mathrm{E}-02$ & $1.02 \mathrm{E}-01$ & $7.2 \%$ & $<1.2 \mathrm{E}-02$ & $<1.2 \mathrm{E}-02$ & - \\
\hline${ }^{241} \mathrm{Pu}(\mathrm{SA})$ & $4.13 \mathrm{E}-01$ & $2.67 \mathrm{E}-01$ & $3.40 \mathrm{E}-01$ & $30 \%$ & $<1.2 \mathrm{E}-01$ & $<1.4 \mathrm{E}-01$ & - \\
\hline${ }^{99} \mathrm{Tc}(\mathrm{IM})$ & $4.12 \mathrm{E}-01$ & $4.44 \mathrm{E}-01$ & $4.28 \mathrm{E}-01$ & $5.4 \%$ & $<8.5 \mathrm{E}-03$ & $<9.5 \mathrm{E}-03$ & - \\
\hline${ }^{237} \mathrm{~Np}(\mathrm{IM})$ & $7.14 \mathrm{E}-04$ & $7.70 \mathrm{E}-04$ & $7.42 \mathrm{E}-04$ & $5.4 \%$ & $<3.5 \mathrm{E}-04$ & $<4.0 \mathrm{E}-04$ & - \\
\hline${ }^{239} \mathrm{Pu}(\mathrm{IM})$ & $8.83 \mathrm{E}-02$ & $7.69 \mathrm{E}-02$ & $8.26 \mathrm{E}-02$ & $9.8 \%$ & $<2.3 \mathrm{E}-02$ & $<2.6 \mathrm{E}-02$ & - \\
\hline${ }^{240} \mathrm{Pu}(\mathrm{IM})$ & $<7.9 \mathrm{E}-02$ & $<7.6 \mathrm{E}-02$ & - & - & $<8.5 \mathrm{E}-02$ & $<9.5 \mathrm{E}-02$ & - \\
\hline${ }^{242} \mathrm{Pu}(\mathrm{IM})$ & $<3.2 \mathrm{E}-03$ & $<3.1 \mathrm{E}-03$ & - & - & $<3.4 \mathrm{E}-03$ & $<3.9 \mathrm{E}-03$ & - \\
\hline
\end{tabular}

* Single Value 
Table 3-10. Composition of the Water Soluble Portion of Solids from Sample HTF-16-06-104

\begin{tabular}{|c|c|c|c|c|c|}
\hline Analyte & $\begin{array}{c}\text { 1st } \\
\text { Replicate } \\
\text { (mg/kg) }\end{array}$ & $\begin{array}{c}\text { 2nd } \\
\text { Replicate } \\
\text { (mg/kg) }\end{array}$ & $\begin{array}{c}\text { Average } \\
\text { (mg/kg) }\end{array}$ & \%RSD & $\begin{array}{c}\text { Blank } \\
(\mathrm{mg} / \mathrm{kg})\end{array}$ \\
\hline $\mathrm{NO}_{3}^{-}$(IC) & $2.20 \mathrm{E}+05$ & $1.58 \mathrm{E}+05$ & $1.89 \mathrm{E}+05$ & $24 \%$ & $<8.6 \mathrm{E}+01$ \\
\hline $\mathrm{NO}_{2}^{-}$(IC) & $2.54 \mathrm{E}+05$ & $2.00 \mathrm{E}+05$ & $2.27 \mathrm{E}+05$ & $17 \%$ & $<8.6 \mathrm{E}+01$ \\
\hline $\mathrm{PO}_{4}{ }^{3-}(\mathrm{IC})$ & $<8.6 \mathrm{E}+01$ & $4.30 \mathrm{E}+02$ & $4.30 \mathrm{E}+02 *$ & - & $<8.6 \mathrm{E}+01$ \\
\hline $\mathrm{SO}_{4}{ }^{2-}(\mathrm{IC})$ & $1.45 \mathrm{E}+04$ & $1.57 \mathrm{E}+04$ & $1.51 \mathrm{E}+04$ & $5.7 \%$ & $<4.3 \mathrm{E}+01$ \\
\hline $\mathrm{C}_{2} \mathrm{O}_{4}{ }^{2-}(\mathrm{IC})$ & $4.30 \mathrm{E}+02$ & $4.30 \mathrm{E}+02$ & $4.30 \mathrm{E}+02$ & $0.0 \%$ & $<8.6 \mathrm{E}+01$ \\
\hline $\mathrm{Cl}^{-}$(IC) & $8.61 E+01$ & $3.44 \mathrm{E}+02$ & $2.15 \mathrm{E}+02$ & $85 \%$ & $<1.7 \mathrm{E}+01$ \\
\hline $\mathrm{F}^{-}$(IC) & $<1.7 \mathrm{E}+01$ & $<1.7 \mathrm{E}+01$ & - & - & $<1.7 \mathrm{E}+01$ \\
\hline $\mathrm{CO}_{3}{ }^{2-}$ (TIC) & $1.46 \mathrm{E}+04$ & $2.07 \mathrm{E}+04$ & $1.76 \mathrm{E}+04$ & $24 \%$ & $<4.3 \mathrm{E}+03$ \\
\hline $\mathrm{OH}_{\text {free }}^{-}(\mathrm{TH})$ & $4.65 E+03$ & $8.20 \mathrm{E}+03$ & $6.43 E+03$ & $39 \%$ & $<2.9 \mathrm{E}+03$ \\
\hline Ag (IE) & $<1.4 \mathrm{E}+01$ & $<1.4 \mathrm{E}+01$ & - & - & $<1.4 \mathrm{E}+01$ \\
\hline Al (IE) & $<2.1 \mathrm{E}+01$ & $<2.1 \mathrm{E}+01$ & - & - & $<2.1 \mathrm{E}+01$ \\
\hline B (IE) & $<3.3 \mathrm{E}+01$ & $<3.3 \mathrm{E}+01$ & - & - & $<3.3 \mathrm{E}+01$ \\
\hline Ba (IE) & $<1.8 \mathrm{E}+01$ & $<1.8 \mathrm{E}+01$ & - & - & $<1.8 \mathrm{E}+01$ \\
\hline Ca (IE) & $3.23 E+02$ & $3.77 \mathrm{E}+02$ & $3.50 \mathrm{E}+02$ & $11 \%$ & $<1.9 \mathrm{E}+01$ \\
\hline Cd (IE) & $<6.6 \mathrm{E}+00$ & $<6.6 \mathrm{E}+00$ & - & - & $<6.6 \mathrm{E}+00$ \\
\hline Ce (IE) & $<4.4 \mathrm{E}+02$ & $<4.4 \mathrm{E}+02$ & - & - & $<4.4 \mathrm{E}+02$ \\
\hline $\mathrm{Cr}$ (IE) & $<3.4 \mathrm{E}+01$ & $<3.4 \mathrm{E}+01$ & - & - & $<3.4 \mathrm{E}+01$ \\
\hline $\mathrm{Cu}$ (IE) & $<2.3 \mathrm{E}+00$ & $<2.3 \mathrm{E}+00$ & - & - & $<2.3 \mathrm{E}+00$ \\
\hline Fe (IE) & $<5.0 \mathrm{E}+00$ & $<5.0 \mathrm{E}+00$ & - & - & $<5.0 \mathrm{E}+00$ \\
\hline Gd (IE) & $<1.9 \mathrm{E}+01$ & $<1.9 \mathrm{E}+01$ & - & - & $<1.9 \mathrm{E}+01$ \\
\hline $\mathrm{K}$ (IE) & $1.22 \mathrm{E}+03$ & $1.45 \mathrm{E}+03$ & $1.33 \mathrm{E}+03$ & $12 \%$ & $<5.4 \mathrm{E}+02$ \\
\hline La (IE) & $<9.2 \mathrm{E}+01$ & $<9.2 \mathrm{E}+01$ & - & - & $<9.2 \mathrm{E}+01$ \\
\hline Li (IE) & $<5.9 \mathrm{E}+01$ & $<5.9 \mathrm{E}+01$ & - & - & $<5.9 \mathrm{E}+01$ \\
\hline $\mathrm{Mg}$ (IE) & $3.72 E+01$ & $5.75 \mathrm{E}+01$ & $4.74 \mathrm{E}+01$ & $30 \%$ & $<1.1 \mathrm{E}+01$ \\
\hline Mn (IE) & $<1.5 \mathrm{E}+00$ & $<1.5 \mathrm{E}+00$ & - & - & $<1.5 \mathrm{E}+00$ \\
\hline Mo (IE) & $<1.7 \mathrm{E}+02$ & $<1.7 \mathrm{E}+02$ & - & - & $<1.7 \mathrm{E}+02$ \\
\hline $\mathrm{Na}$ (IE) & $2.23 \mathrm{E}+05$ & $2.01 E+05$ & $2.12 \mathrm{E}+05$ & $7.5 \%$ & $<1.8 \mathrm{E}+01$ \\
\hline
\end{tabular}

Results represent the estimated composition as $\mathrm{mg} / \mathrm{kg}$ of dried solids based on analysis of solutions from water contact with a portion of damp solids from the sample. The wt \% solids for all three Tank $16 \mathrm{H}$ annulus samples ranged from $81 \%$ to $93 \%$ indicating very little water was present in the samples.

* Single Value Divide $\mathrm{mg} / \mathrm{kg}$ values by $1 \mathrm{E}+04$ to convert to wt \% basis 
Table 3-10. Composition of the Water Soluble Portion of Solids from Sample HTF-16-06-104 (continued)

\begin{tabular}{|c|c|c|c|c|c|}
\hline Analyte & $\begin{array}{c}\text { 1st } \\
\text { Replicate } \\
\text { (mg/kg) }\end{array}$ & $\begin{array}{c}\text { 2nd } \\
\text { Replicate } \\
\text { (mg/kg) }\end{array}$ & $\begin{array}{c}\text { Average } \\
\text { (mg/kg) }\end{array}$ & \%RSD & $\begin{array}{c}\text { Blank } \\
\text { (mg/kg) }\end{array}$ \\
\hline $\mathrm{Ni}$ (IE) & $<4.9 \mathrm{E}+01$ & $<4.9 \mathrm{E}+01$ & - & - & $<4.9 \mathrm{E}+01$ \\
\hline $\mathrm{P}$ (IE) & $<3.2 \mathrm{E}+02$ & $<3.2 \mathrm{E}+02$ & - & - & $<3.2 \mathrm{E}+02$ \\
\hline $\mathrm{Pb}$ (IE) & $<4.2 \mathrm{E}+02$ & $<4.2 \mathrm{E}+02$ & - & - & $<4.2 \mathrm{E}+02$ \\
\hline$S$ (IE) & $5.38 \mathrm{E}+03$ & $6.93 E+03$ & $6.16 \mathrm{E}+03$ & $18 \%$ & $<1.1 \mathrm{E}+02$ \\
\hline Sb (IE) & $<1.0 \mathrm{E}+02$ & $<1.0 \mathrm{E}+02$ & - & - & $<1.0 \mathrm{E}+02$ \\
\hline Si (IE) & $2.44 \mathrm{E}+03$ & $4.66 \mathrm{E}+03$ & $3.55 E+03$ & $44 \%$ & $6.35 E+01$ \\
\hline Sn (IE) & $<9.5 \mathrm{E}+02$ & $<9.5 \mathrm{E}+02$ & - & - & $<9.5 \mathrm{E}+02$ \\
\hline Sr (IE) & $<6.0 \mathrm{E}+01$ & $<6.0 \mathrm{E}+01$ & - & - & $<6.0 \mathrm{E}+01$ \\
\hline $\mathrm{Ti}$ (IE) & $<3.3 \mathrm{E}+00$ & $<3.3 \mathrm{E}+00$ & - & - & $<3.3 \mathrm{E}+00$ \\
\hline $\mathrm{U}$ (IE) & $9.56 \mathrm{E}+01$ & $2.42 \mathrm{E}+02$ & $1.69 E+02$ & $61 \%$ & $<3.9 \mathrm{E}+01$ \\
\hline V (IE) & $<1.2 \mathrm{E}+01$ & $<1.2 \mathrm{E}+01$ & - & - & $<1.2 \mathrm{E}+01$ \\
\hline $\mathrm{Zn}$ (IE) & $<2.6 \mathrm{E}+01$ & $<2.6 \mathrm{E}+01$ & - & - & $<2.6 \mathrm{E}+01$ \\
\hline $\mathrm{Zr}$ (IE) & $<6.8 \mathrm{E}+00$ & $<6.8 \mathrm{E}+00$ & - & - & $<6.8 \mathrm{E}+00$ \\
\hline
\end{tabular}

Results represent the estimated composition as $\mathrm{mg} / \mathrm{kg}$ of dried solids based on analysis of solutions from water contact with a portion of damp solids from the sample. The wt \% solids for all three Tank $16 \mathrm{H}$ annulus samples ranged from $81 \%$ to $93 \%$ indicating very little water was present in the samples.

* Single Value Divide $\mathrm{mg} / \mathrm{kg}$ values by $1 \mathrm{E}+04$ to convert to wt \% basis 
Table 3-11. Composition of the Water Soluble Portion of Solids from Sample HTF-16-06-105

\begin{tabular}{|c|c|c|c|c|c|}
\hline Analyte & $\begin{array}{c}\text { 1st } \\
\text { Replicate } \\
\text { (mg/kg) }\end{array}$ & $\begin{array}{c}\text { 2nd } \\
\text { Replicate } \\
\text { (mg/kg) }\end{array}$ & $\begin{array}{c}\text { Average } \\
\text { (mg/kg) }\end{array}$ & \%RSD & $\begin{array}{c}\text { Blank } \\
(\mathrm{mg} / \mathrm{kg})\end{array}$ \\
\hline $\mathrm{NO}_{3}^{-}(\mathrm{IC})$ & $1.36 \mathrm{E}+05$ & $1.04 \mathrm{E}+05$ & $1.20 \mathrm{E}+05$ & $19 \%$ & $<9.8 \mathrm{E}+01$ \\
\hline $\mathrm{NO}_{2}^{-}(\mathrm{IC})$ & $1.63 \mathrm{E}+05$ & $1.36 \mathrm{E}+05$ & $1.49 \mathrm{E}+05$ & $13 \%$ & $<9.8 \mathrm{E}+01$ \\
\hline $\mathrm{PO}_{4}{ }^{3-}(\mathrm{IC})$ & $4.88 \mathrm{E}+02$ & $3.91 E+02$ & $4.40 \mathrm{E}+02$ & $16 \%$ & $<9.8 \mathrm{E}+01$ \\
\hline $\mathrm{SO}_{4}{ }^{2-}(\mathrm{IC})$ & $1.24 \mathrm{E}+04$ & $1.04 \mathrm{E}+04$ & $1.14 \mathrm{E}+04$ & $13 \%$ & $<4.9 \mathrm{E}+01$ \\
\hline $\mathrm{C}_{2} \mathrm{O}_{4}{ }^{2-}(\mathrm{IC})$ & $2.05 E+03$ & $2.05 E+03$ & $2.05 E+03$ & $0.0 \%$ & $<9.8 \mathrm{E}+01$ \\
\hline $\mathrm{Cl}^{-}$(IC) & $1.95 E+02$ & $1.95 E+02$ & $1.95 \mathrm{E}+02$ & $0.0 \%$ & $<2.0 \mathrm{E}+01$ \\
\hline $\mathrm{F}^{-}$(IC) & $<2.0 \mathrm{E}+01$ & $<2.0 \mathrm{E}+01$ & - & - & $<2.0 \mathrm{E}+01$ \\
\hline $\mathrm{CO}_{3}{ }^{2-}$ (TIC) & $3.03 E+04$ & $2.88 E+04$ & $2.96 \mathrm{E}+04$ & $3.5 \%$ & $<4.9 \mathrm{E}+03$ \\
\hline $\mathrm{OH}_{\text {free }}^{-}(\mathrm{TH})$ & $6.68 \mathrm{E}+03$ & $6.26 \mathrm{E}+03$ & $6.47 \mathrm{E}+03$ & $4.5 \%$ & $<3.3 \mathrm{E}+03$ \\
\hline Ag (IE) & $<1.6 \mathrm{E}+01$ & $<1.6 \mathrm{E}+01$ & - & - & $<1.6 \mathrm{E}+01$ \\
\hline Al (IE) & $<2.3 \mathrm{E}+01$ & $<2.3 \mathrm{E}+01$ & - & - & $<2.3 \mathrm{E}+01$ \\
\hline B (IE) & $<3.7 \mathrm{E}+01$ & $<3.7 \mathrm{E}+01$ & - & - & $<3.7 \mathrm{E}+01$ \\
\hline $\mathrm{Ba}$ (IE) & $<2.0 \mathrm{E}+01$ & $<2.0 \mathrm{E}+01$ & - & - & $<2.0 \mathrm{E}+01$ \\
\hline Ca (IE) & $3.27 \mathrm{E}+02$ & $3.17 \mathrm{E}+02$ & $3.22 \mathrm{E}+02$ & $2.2 \%$ & $<2.2 \mathrm{E}+01$ \\
\hline Cd (IE) & $<7.5 \mathrm{E}+00$ & $<7.5 \mathrm{E}+00$ & - & - & $<7.5 \mathrm{E}+00$ \\
\hline Ce (IE) & $<5.0 \mathrm{E}+02$ & $<5.0 \mathrm{E}+02$ & - & - & $<5.0 \mathrm{E}+02$ \\
\hline $\mathrm{Cr}$ (IE) & $<3.8 \mathrm{E}+01$ & $<3.8 \mathrm{E}+01$ & - & - & $<3.8 \mathrm{E}+01$ \\
\hline $\mathrm{Cu}$ (IE) & $<2.6 \mathrm{E}+00$ & $<2.6 \mathrm{E}+00$ & - & - & $<2.6 \mathrm{E}+00$ \\
\hline $\mathrm{Fe}$ (IE) & $<5.7 \mathrm{E}+00$ & $<5.7 \mathrm{E}+00$ & - & - & $<5.7 \mathrm{E}+00$ \\
\hline Gd (IE) & $<2.2 \mathrm{E}+01$ & $<2.2 \mathrm{E}+01$ & - & - & $<2.2 \mathrm{E}+01$ \\
\hline K (IE) & $7.58 \mathrm{E}+02$ & $7.81 \mathrm{E}+02$ & $7.70 \mathrm{E}+02$ & $2.1 \%$ & $<6.1 \mathrm{E}+02$ \\
\hline La (IE) & $<1.0 \mathrm{E}+02$ & $<1.0 \mathrm{E}+02$ & - & - & $<1.0 \mathrm{E}+02$ \\
\hline Li (IE) & $<6.7 \mathrm{E}+01$ & $<6.7 \mathrm{E}+01$ & - & - & $<6.7 \mathrm{E}+01$ \\
\hline Mg (IE) & $<3.8 \mathrm{E}+01$ & $<3.5 \mathrm{E}+01$ & - & - & $<1.2 \mathrm{E}+01$ \\
\hline Mn (IE) & $<1.7 \mathrm{E}+00$ & $<1.7 \mathrm{E}+00$ & - & - & $<1.7 \mathrm{E}+00$ \\
\hline Mo (IE) & $<2.0 \mathrm{E}+02$ & $<2.0 \mathrm{E}+02$ & - & - & $<2.0 \mathrm{E}+02$ \\
\hline $\mathrm{Na}$ (IE) & $2.54 \mathrm{E}+05$ & $2.33 E+05$ & $2.44 \mathrm{E}+05$ & $6.0 \%$ & $<2.0 \mathrm{E}+01$ \\
\hline
\end{tabular}

Results represent the estimated composition as $\mathrm{mg} / \mathrm{kg}$ of dried solids based on analysis of solutions from water contact with a portion of damp solids from the sample. The wt \% solids for all three Tank $16 \mathrm{H}$ annulus samples ranged from $81 \%$ to $93 \%$ indicating very little water was present in the samples.

* Single Value Divide $\mathrm{mg} / \mathrm{kg}$ values by $1 \mathrm{E}+04$ to convert to wt \% basis 
Table 3-11. Composition of the Water Soluble Portion of Solids from Sample HTF-16-06-105 (continued)

\begin{tabular}{|c|c|c|c|c|c|}
\hline Analyte & $\begin{array}{c}\text { 1st } \\
\text { Replicate } \\
\text { (mg/kg) }\end{array}$ & $\begin{array}{c}\text { 2nd } \\
\text { Replicate } \\
\text { (mg/kg) }\end{array}$ & $\begin{array}{c}\text { Average } \\
\text { (mg/kg) }\end{array}$ & \%RSD & $\begin{array}{c}\text { Blank } \\
\text { (mg/kg) }\end{array}$ \\
\hline $\mathrm{Ni}$ (IE) & $<5.6 \mathrm{E}+01$ & $<5.6 \mathrm{E}+01$ & - & - & $<5.6 \mathrm{E}+01$ \\
\hline $\mathrm{P}$ (IE) & $<3.6 \mathrm{E}+02$ & $<3.6 \mathrm{E}+02$ & - & - & $<3.6 \mathrm{E}+02$ \\
\hline $\mathrm{Pb}$ (IE) & $<4.8 \mathrm{E}+02$ & $<4.8 \mathrm{E}+02$ & - & - & $<4.8 \mathrm{E}+02$ \\
\hline S (IE) & $5.26 \mathrm{E}+03$ & $3.58 E+03$ & $4.42 E+03$ & $27 \%$ & $<1.2 \mathrm{E}+02$ \\
\hline Sb (IE) & $<1.2 \mathrm{E}+02$ & $<1.2 \mathrm{E}+02$ & - & - & $<1.2 \mathrm{E}+02$ \\
\hline Si (IE) & $2.12 \mathrm{E}+04$ & $2.17 \mathrm{E}+04$ & $2.14 \mathrm{E}+04$ & $1.6 \%$ & $5.81 E+01$ \\
\hline Sn (IE) & $<1.1 \mathrm{E}+03$ & $<1.1 \mathrm{E}+03$ & - & - & $<1.1 \mathrm{E}+03$ \\
\hline Sr (IE) & $<6.8 \mathrm{E}+01$ & $<6.8 \mathrm{E}+01$ & - & - & $<6.9 \mathrm{E}+01$ \\
\hline $\mathrm{Ti}$ (IE) & $<3.7 \mathrm{E}+00$ & $<3.7 \mathrm{E}+00$ & - & - & $<3.7 \mathrm{E}+00$ \\
\hline U (IE) & $6.15 \mathrm{E}+01$ & $5.19 \mathrm{E}+01$ & $5.67 \mathrm{E}+01$ & $12 \%$ & $<4.4 \mathrm{E}+01$ \\
\hline V (IE) & $<1.4 \mathrm{E}+01$ & $<1.4 \mathrm{E}+01$ & - & - & $<1.4 \mathrm{E}+01$ \\
\hline $\mathrm{Zn}$ (IE) & $<2.9 \mathrm{E}+01$ & $<2.9 \mathrm{E}+01$ & - & - & $<2.9 \mathrm{E}+01$ \\
\hline Zr (IE) & $<7.7 \mathrm{E}+00$ & $<7.7 \mathrm{E}+00$ & - & - & $<7.7 \mathrm{E}+00$ \\
\hline
\end{tabular}

Results represent the estimated composition as $\mathrm{mg} / \mathrm{kg}$ of dried solids based on analysis of solutions from water contact with a portion of damp solids from the sample. The wt \% solids for all three Tank $16 \mathrm{H}$ annulus samples ranged from $81 \%$ to $93 \%$ indicating very little water was present in the samples.

* Single Value Divide $\mathrm{mg} / \mathrm{kg}$ values by $1 \mathrm{E}+04$ to convert to wt \% basis 
Table 3-12. Composition of the Water Soluble Portion of Solids from Sample HTF-16-06-106

\begin{tabular}{|c|c|c|c|c|c|}
\hline Analyte & $\begin{array}{c}\text { 1st } \\
\text { Replicate } \\
\text { (mg/kg) }\end{array}$ & $\begin{array}{c}\text { 2nd } \\
\text { Replicate } \\
\text { (mg/kg) }\end{array}$ & $\begin{array}{c}\text { Average } \\
\text { (mg/kg) }\end{array}$ & \%RSD & $\begin{array}{c}\text { Blank } \\
(\mathrm{mg} / \mathrm{kg})\end{array}$ \\
\hline $\mathrm{NO}_{3}^{-}(\mathrm{IC})$ & $5.10 \mathrm{E}+04$ & $5.03 E+04$ & $5.07 \mathrm{E}+04$ & $1.0 \%$ & $<9.5 \mathrm{E}+01$ \\
\hline $\mathrm{NO}_{2}^{-}$(IC) & $8.07 \mathrm{E}+04$ & $8.03 E+04$ & $8.05 E+04$ & $0.4 \%$ & $<9.5 \mathrm{E}+01$ \\
\hline $\mathrm{PO}_{4}^{3-}$ (IC) & $<9.5 \mathrm{E}+01$ & $<9.5 E+01$ & - & - & $<9.5 \mathrm{E}+01$ \\
\hline $\mathrm{SO}_{4}{ }^{2-}(\mathrm{IC})$ & $3.71 E+03$ & $3.90 \mathrm{E}+03$ & $3.80 \mathrm{E}+03$ & $3.6 \%$ & $<4.8 \mathrm{E}+01$ \\
\hline $\mathrm{C}_{2} \mathrm{O}_{4}{ }^{2-}$ (IC) & $1.90 \mathrm{E}+02$ & $3.80 \mathrm{E}+02$ & $2.85 E+02$ & $47 \%$ & $<9.5 \mathrm{E}+01$ \\
\hline $\mathrm{Cl}^{-}$(IC) & $1.90 \mathrm{E}+02$ & $3.80 \mathrm{E}+02$ & $2.85 \mathrm{E}+02$ & $47 \%$ & $<1.9 \mathrm{E}+01$ \\
\hline $\mathrm{F}^{-}$(IC) & $<1.9 \mathrm{E}+01$ & $<1.9 \mathrm{E}+01$ & - & - & $<1.9 \mathrm{E}+01$ \\
\hline $\mathrm{CO}_{3}{ }^{2-}$ (TIC) & $2.09 E+04$ & $2.24 \mathrm{E}+04$ & $2.16 \mathrm{E}+04$ & $4.7 \%$ & $0.00 \mathrm{E}+00$ \\
\hline $\mathrm{OH}_{\text {free }}^{-}(\mathrm{TH})$ & $1.73 E+04$ & $1.84 \mathrm{E}+04$ & $1.79 E+04$ & $4.5 \%$ & $<3.2 \mathrm{E}+03$ \\
\hline Ag (IE) & $<1.6 \mathrm{E}+01$ & $<1.6 \mathrm{E}+01$ & - & - & $<1.6 \mathrm{E}+01$ \\
\hline Al (IE) & $<3.1 \mathrm{E}+01$ & $<3.8 \mathrm{E}+01$ & - & - & $<2.3 \mathrm{E}+01$ \\
\hline B (IE) & $<3.6 \mathrm{E}+01$ & $<3.6 \mathrm{E}+01$ & - & - & $<3.6 \mathrm{E}+01$ \\
\hline Ba (IE) & $<2.0 \mathrm{E}+01$ & $<2.0 \mathrm{E}+01$ & - & - & $<2.0 \mathrm{E}+01$ \\
\hline Ca (IE) & $2.63 E+02$ & $3.10 \mathrm{E}+02$ & $2.87 \mathrm{E}+02$ & $12 \%$ & $<2.1 \mathrm{E}+01$ \\
\hline Cd (IE) & $<7.3 \mathrm{E}+00$ & $<7.3 \mathrm{E}+00$ & - & - & $<7.3 \mathrm{E}+00$ \\
\hline Ce (IE) & $<4.8 \mathrm{E}+02$ & $<4.8 \mathrm{E}+02$ & - & - & $<4.8 \mathrm{E}+02$ \\
\hline $\mathrm{Cr}$ (IE) & $<3.7 \mathrm{E}+01$ & $<3.7 \mathrm{E}+01$ & - & - & $<3.7 \mathrm{E}+01$ \\
\hline $\mathrm{Cu}$ (IE) & $<2.6 \mathrm{E}+00$ & $<2.6 \mathrm{E}+00$ & - & - & $<2.6 \mathrm{E}+00$ \\
\hline $\mathrm{Fe}$ (IE) & $<5.5 \mathrm{E}+00$ & $<5.5 \mathrm{E}+00$ & - & - & $<5.5 \mathrm{E}+00$ \\
\hline Gd (IE) & $<2.1 \mathrm{E}+01$ & $<2.1 \mathrm{E}+01$ & - & - & $<2.1 \mathrm{E}+01$ \\
\hline K (IE) & $7.79 E+02$ & $7.99 \mathrm{E}+02$ & $7.89 \mathrm{E}+02$ & $1.7 \%$ & $<6.0 \mathrm{E}+02$ \\
\hline La (IE) & $<1.0 \mathrm{E}+02$ & $<1.0 \mathrm{E}+02$ & - & - & $<1.0 \mathrm{E}+02$ \\
\hline Li (IE) & $<6.5 \mathrm{E}+01$ & $<6.5 \mathrm{E}+01$ & - & - & $<6.5 \mathrm{E}+01$ \\
\hline Mg (IE) & $4.02 \mathrm{E}+01$ & $4.73 E+01$ & $4.37 \mathrm{E}+01$ & $11 \%$ & $<1.2 \mathrm{E}+01$ \\
\hline Mn (IE) & $<1.6 \mathrm{E}+00$ & $<1.6 \mathrm{E}+00$ & - & - & $<1.6 \mathrm{E}+00$ \\
\hline Mo (IE) & $<1.9 \mathrm{E}+02$ & $<1.9 \mathrm{E}+02$ & - & - & $<1.9 \mathrm{E}+02$ \\
\hline $\mathrm{Na}$ (IE) & $1.24 \mathrm{E}+05$ & $1.35 E+05$ & $1.29 E+05$ & $6.3 \%$ & $<2.0 \mathrm{E}+01$ \\
\hline
\end{tabular}

Results represent the estimated composition as $\mathrm{mg} / \mathrm{kg}$ of dried solids based on analysis of solutions from water contact with a portion of damp solids from the sample. The wt \% solids for all three Tank $16 \mathrm{H}$ annulus samples ranged from $81 \%$ to $93 \%$ indicating very little water was present in the samples.

* Single Value Divide $\mathrm{mg} / \mathrm{kg}$ values by $1 \mathrm{E}+04$ to convert to wt \% basis 
Table 3-12. Composition of the Water Soluble Portion of Solids from Sample HTF-16-06-106 (continued)

\begin{tabular}{|c|c|c|c|c|c|}
\hline Analyte & $\begin{array}{c}\text { 1st } \\
\text { Replicate } \\
(\mathrm{mg} / \mathrm{kg})\end{array}$ & $\begin{array}{c}\text { 2nd } \\
\text { Replicate } \\
\text { (mg/kg) }\end{array}$ & $\begin{array}{c}\text { Average } \\
\text { (mg/kg) }\end{array}$ & \%RSD & $\begin{array}{c}\text { Blank } \\
\text { (mg/kg) }\end{array}$ \\
\hline $\mathrm{Ni}$ (IE) & $<5.4 \mathrm{E}+01$ & $<5.4 \mathrm{E}+01$ & - & - & $<5.4 \mathrm{E}+01$ \\
\hline $\mathrm{P}$ (IE) & $<3.5 \mathrm{E}+02$ & $<3.5 \mathrm{E}+02$ & - & - & $<3.5 \mathrm{E}+02$ \\
\hline $\mathrm{Pb}$ (IE) & $<4.6 \mathrm{E}+02$ & $<4.6 \mathrm{E}+02$ & - & - & $<4.6 \mathrm{E}+02$ \\
\hline S (IE) & $1.46 \mathrm{E}+03$ & $1.59 \mathrm{E}+03$ & $1.53 \mathrm{E}+03$ & $5.8 \%$ & $<1.2 \mathrm{E}+02$ \\
\hline Sb (IE) & $<1.1 \mathrm{E}+02$ & $<1.1 \mathrm{E}+02$ & - & - & $<1.1 \mathrm{E}+02$ \\
\hline Si (IE) & $3.99 E+03$ & $5.19 \mathrm{E}+03$ & $4.59 E+03$ & $18 \%$ & $<2.2 \mathrm{E}+01$ \\
\hline Sn (IE) & $<1.0 \mathrm{E}+03$ & $<1.0 \mathrm{E}+03$ & - & - & $<1.0 \mathrm{E}+03$ \\
\hline Sr (IE) & $<6.7 \mathrm{E}+01$ & $<6.7 \mathrm{E}+01$ & - & - & $<6.7 \mathrm{E}+01$ \\
\hline $\mathrm{Ti}$ (IE) & $<3.6 \mathrm{E}+00$ & $<3.6 \mathrm{E}+00$ & - & - & $<3.6 \mathrm{E}+00$ \\
\hline U (IE) & $5.09 \mathrm{E}+01$ & $4.95 \mathrm{E}+01$ & $5.02 \mathrm{E}+01$ & $2.1 \%$ & $<4.3 \mathrm{E}+01$ \\
\hline $\mathrm{V}$ (IE) & $<1.3 \mathrm{E}+01$ & $<1.4 \mathrm{E}+01$ & - & - & $<1.4 \mathrm{E}+01$ \\
\hline $\mathrm{Zn}$ (IE) & $<2.8 \mathrm{E}+01$ & $<2.8 \mathrm{E}+01$ & - & - & $<2.8 \mathrm{E}+01$ \\
\hline $\mathrm{Zr}$ (IE) & $<7.5 \mathrm{E}+00$ & $<7.5 \mathrm{E}+00$ & - & - & $<7.5 \mathrm{E}+00$ \\
\hline
\end{tabular}

Results represent the estimated composition as $\mathrm{mg} / \mathrm{kg}$ of dried solids based on analysis of solutions from water contact with a portion of damp solids from the sample. The wt \% solids for all three Tank $16 \mathrm{H}$ annulus samples ranged from $81 \%$ to $93 \%$ indicating very little water was present in the samples.

* Single Value Divide $\mathrm{mg} / \mathrm{kg}$ values by $1 \mathrm{E}+04$ to convert to wt \% basis 
WSRC-STI-2008-00203, REV. 0

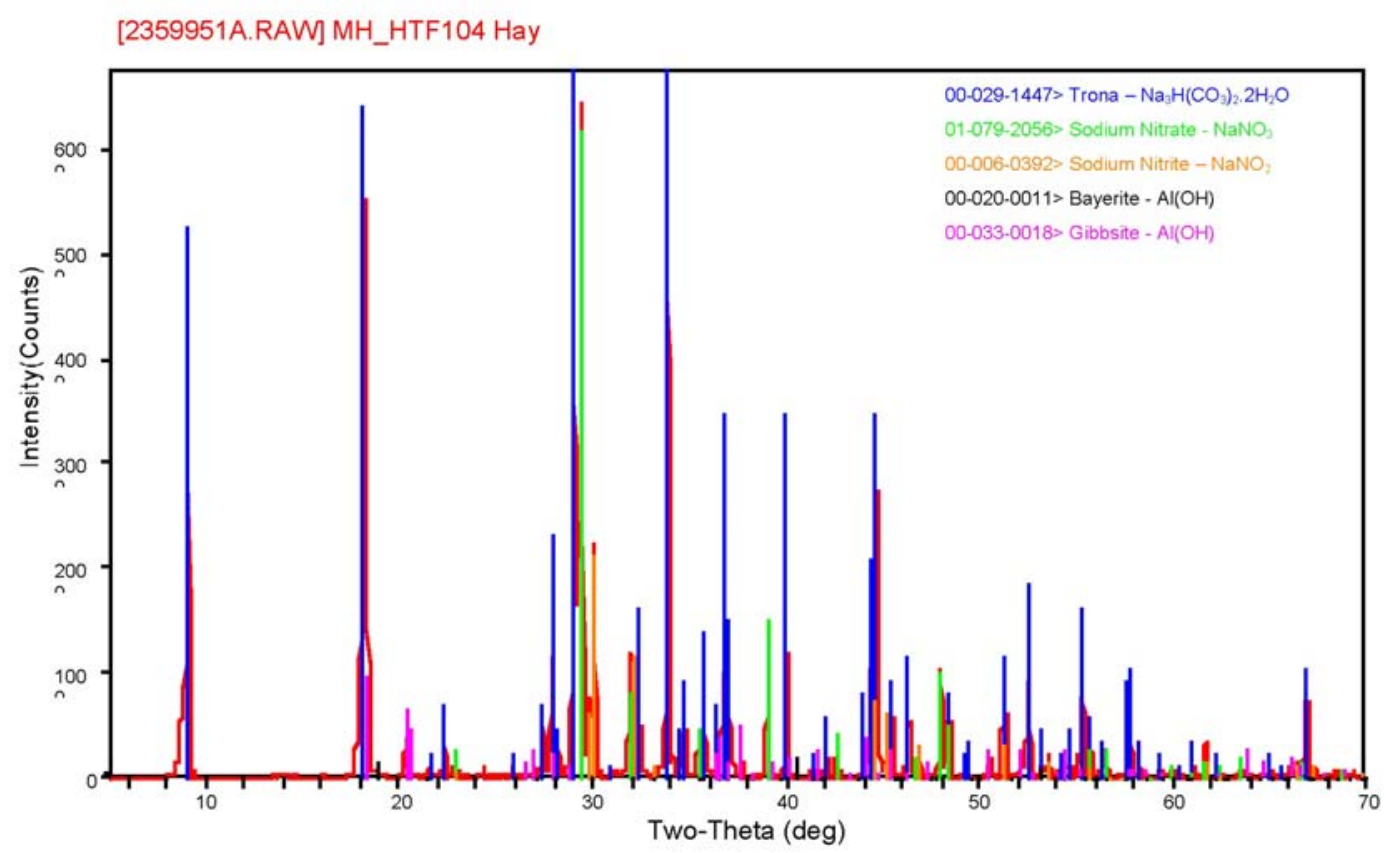

Figure 3.1 X-Ray Diffraction for Solids from Tank 16H Sample HTF-16-06-104 


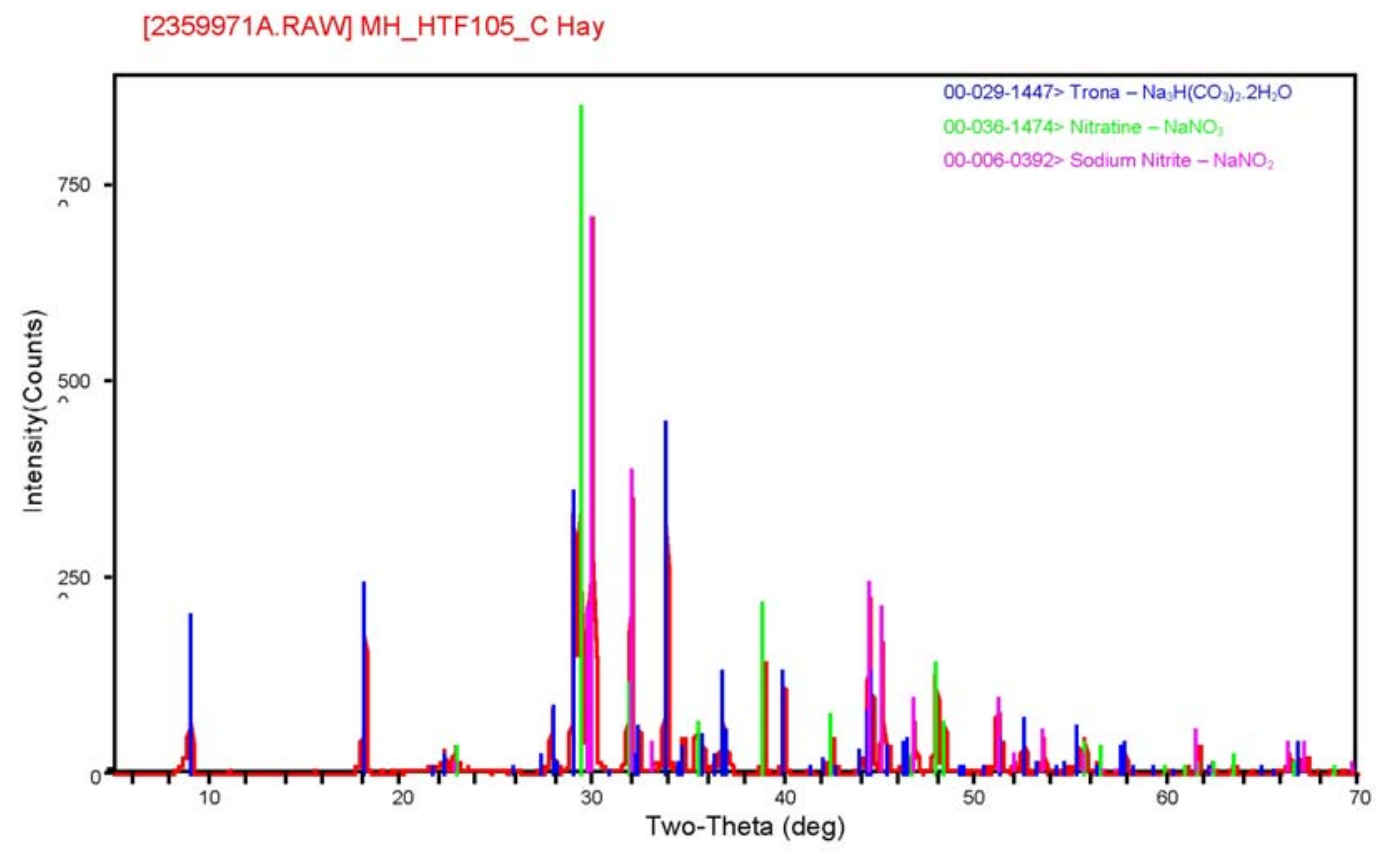

Figure 3.2 X-Ray Diffraction for Solids from Tank 16H Sample HTF-16-06-105C

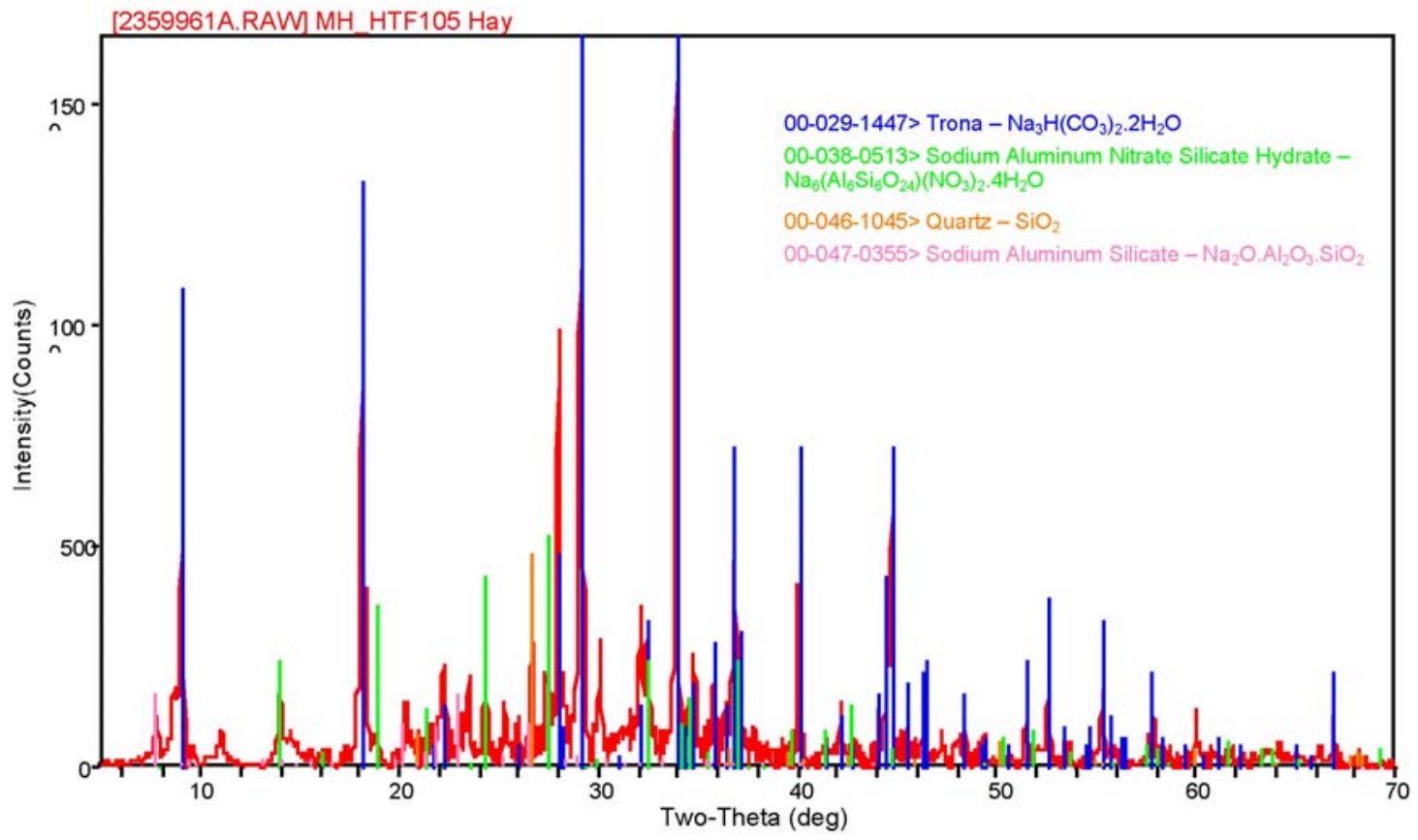

Figure 3.3 X-Ray Diffraction for Solids from Tank 16H Sample HTF-16-06-105 


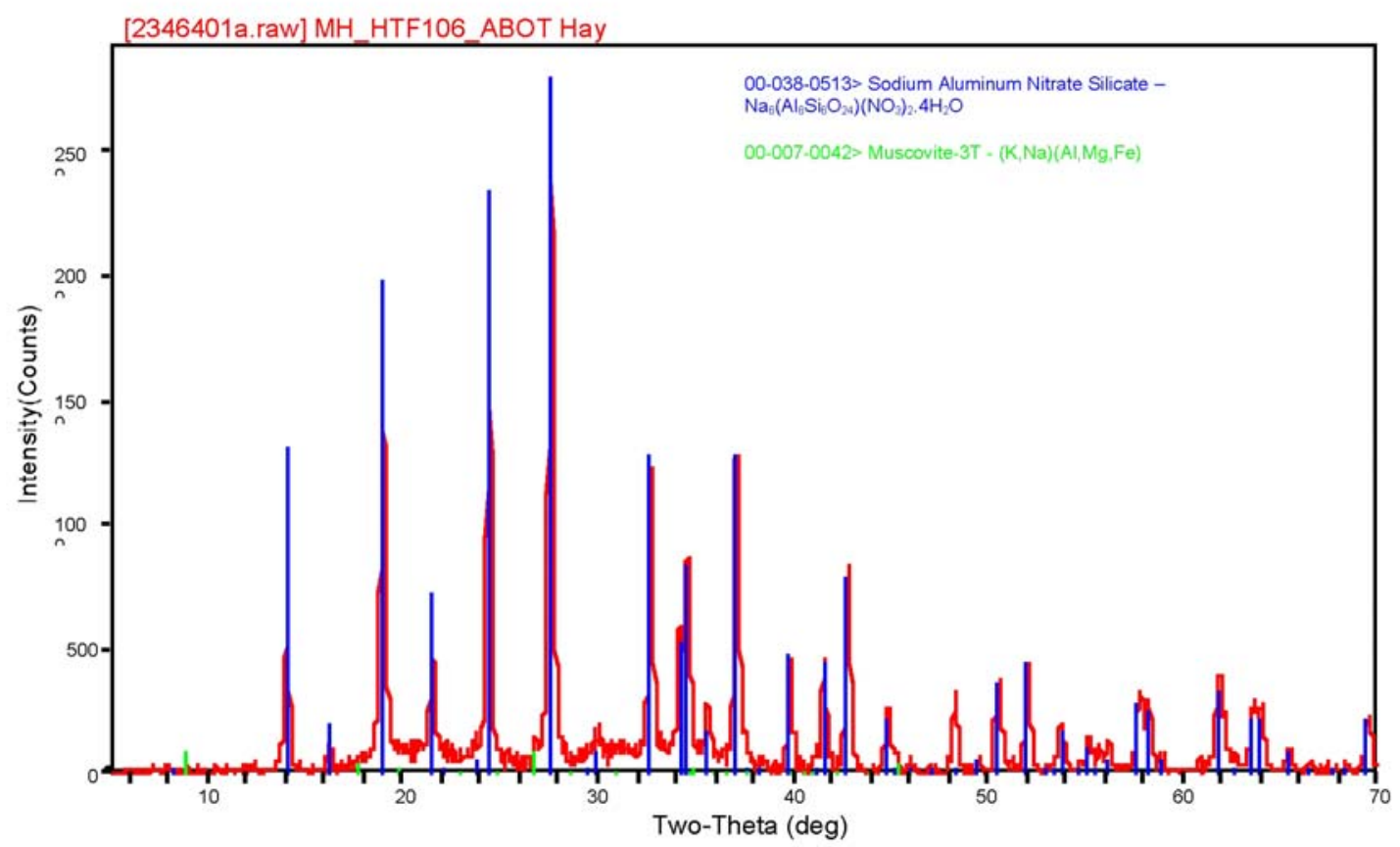

Figure 3.4 X-Ray Diffraction for Solids from Tank 16H Sample HTF-16-06-106-ABOT

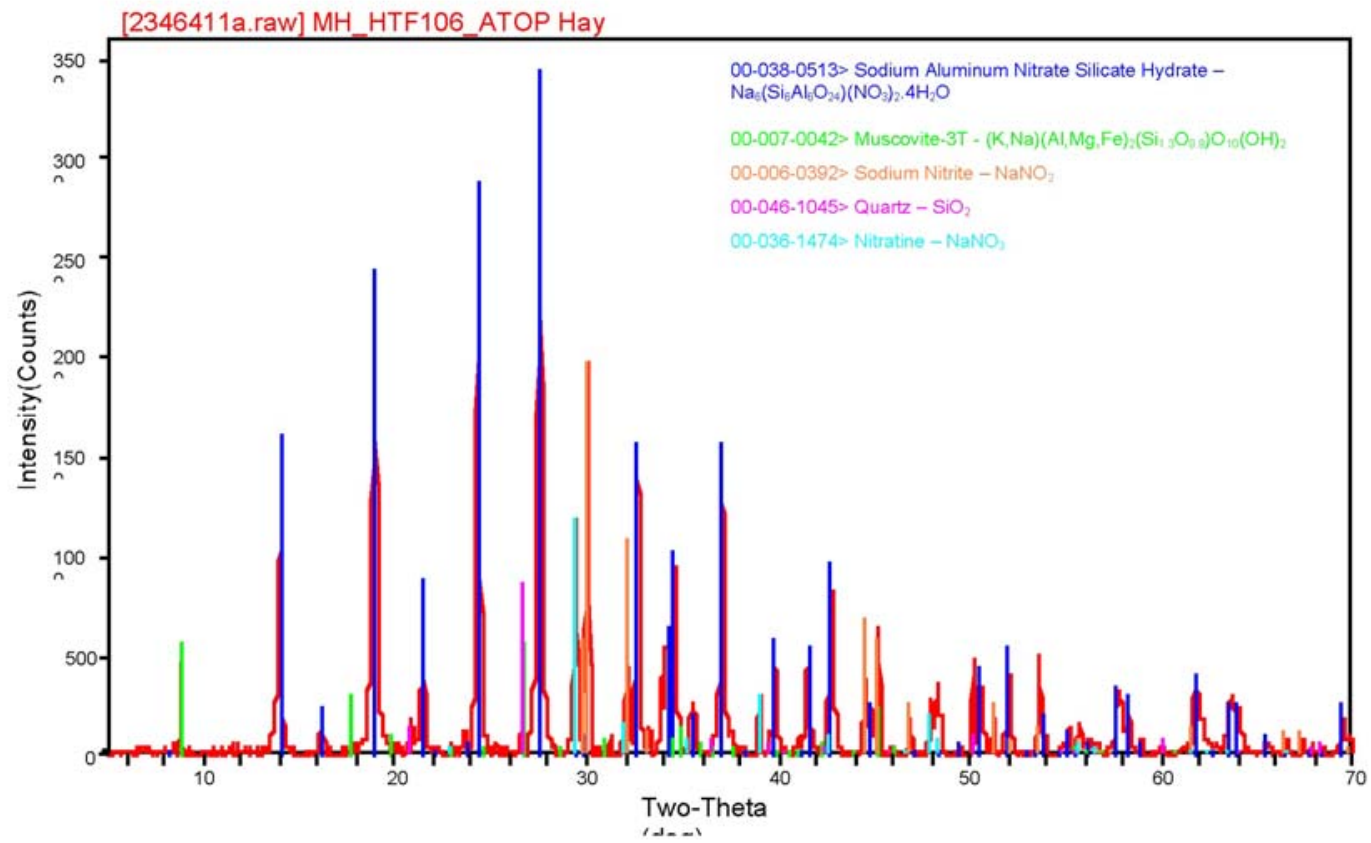

Figure 3.5 X-Ray Diffraction for Solids from Tank 16H Sample HTF-16-06-106-ATOP 


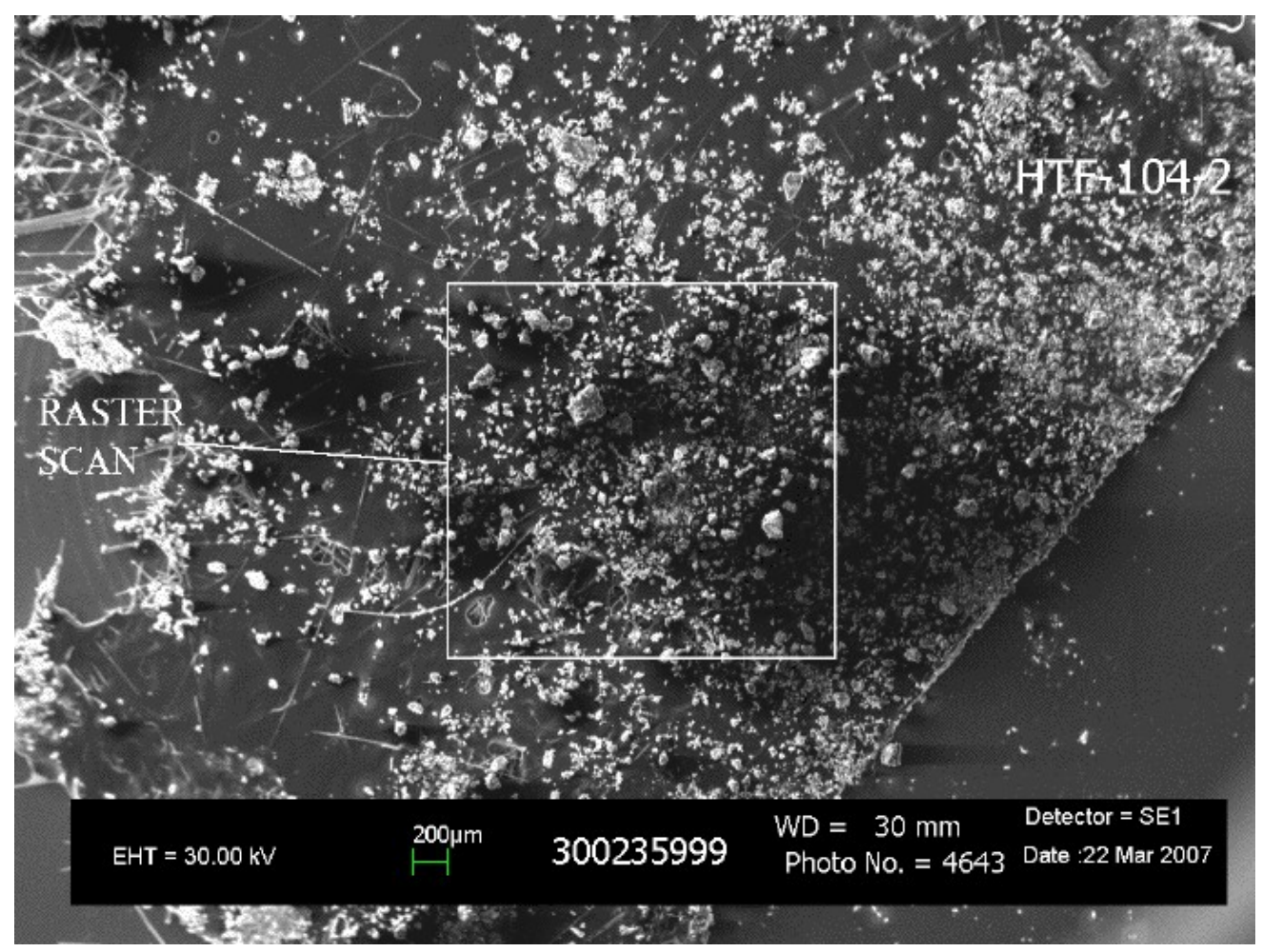

Figure 3.6 SEM Micrograph of Solids from Tank 16H Sample HTF-16-06-104-2 (15X Magnification)

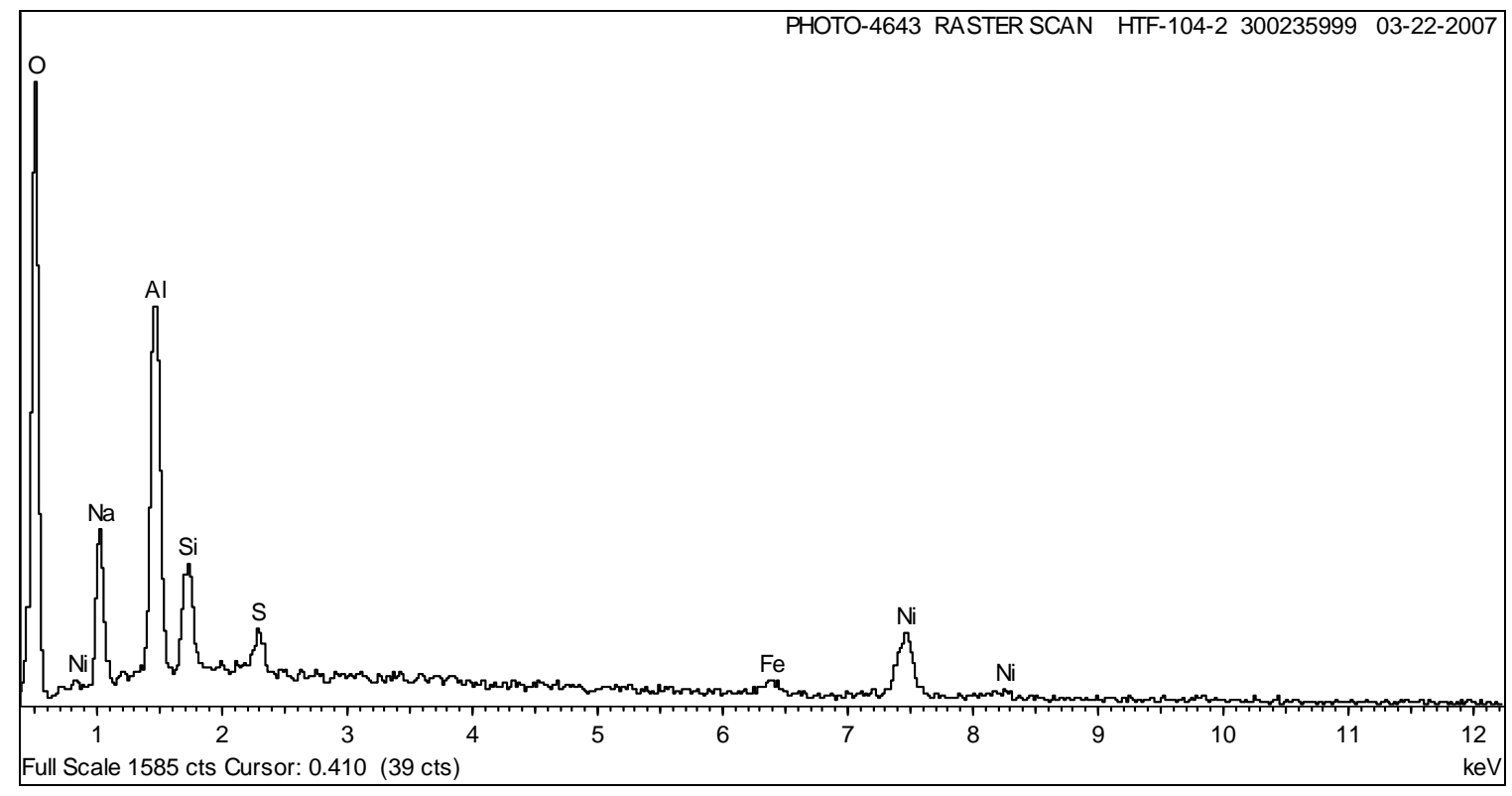

Figure 3.7 Spectrum of Raster Scan from Figure 3.6 


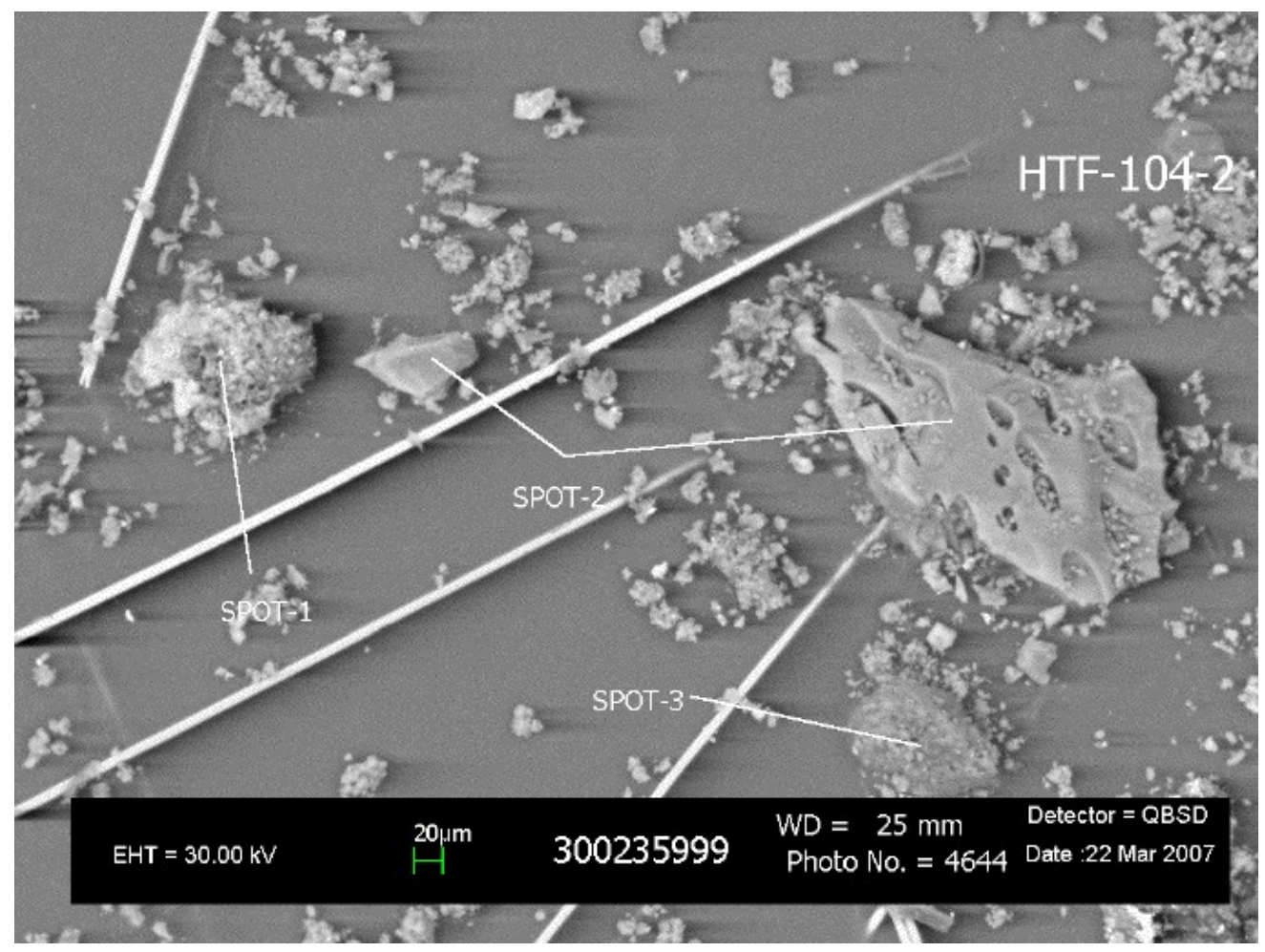

Figure 3.8 SEM Micrograph of Solids from Tank 16H Sample HTF-16-06-104-2 (130X Magnification)

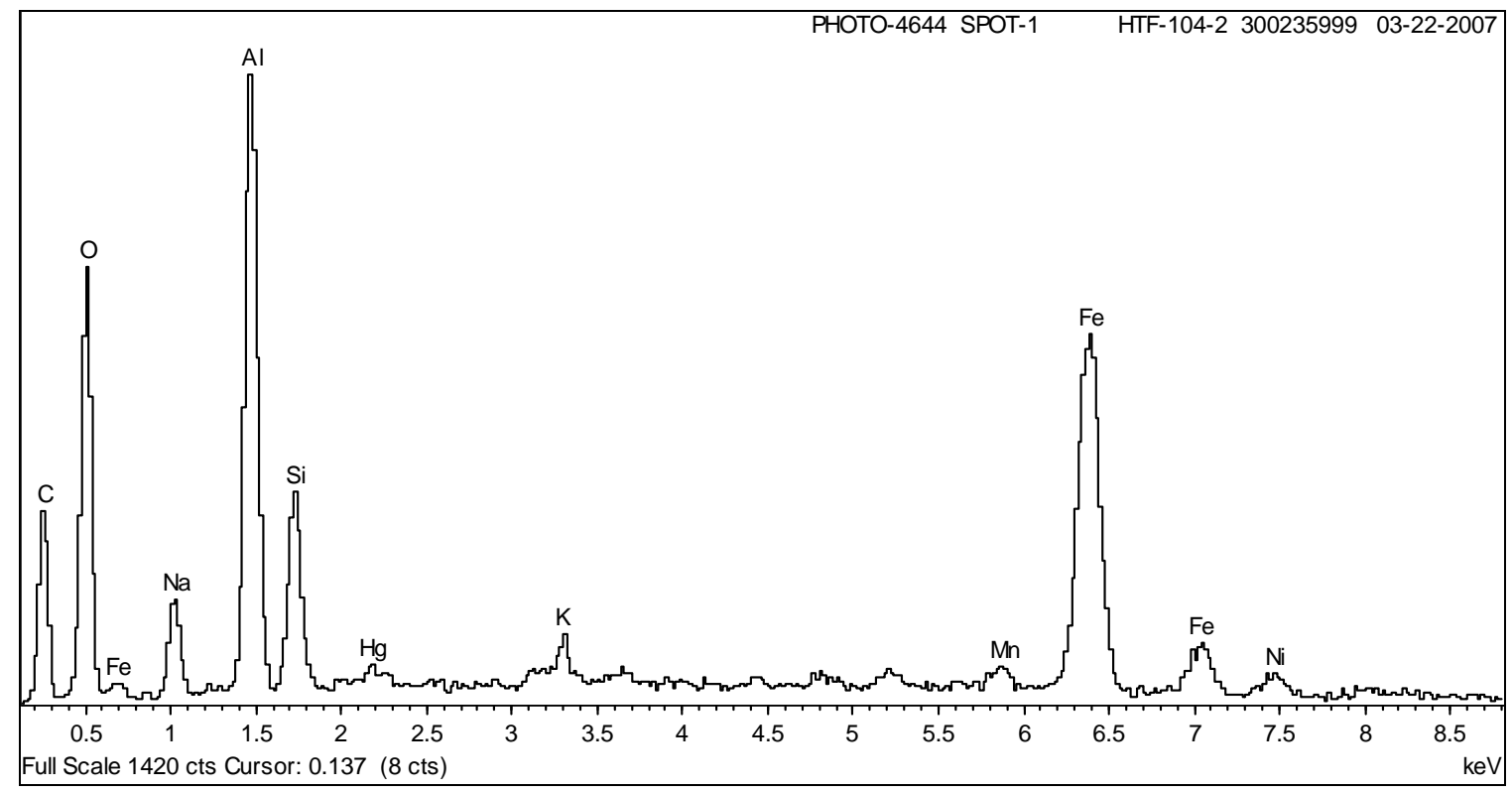

Figure 3.9 Spectrum of Spot 1 from Figure 3.8 
WSRC-STI-2008-00203, REV. 0

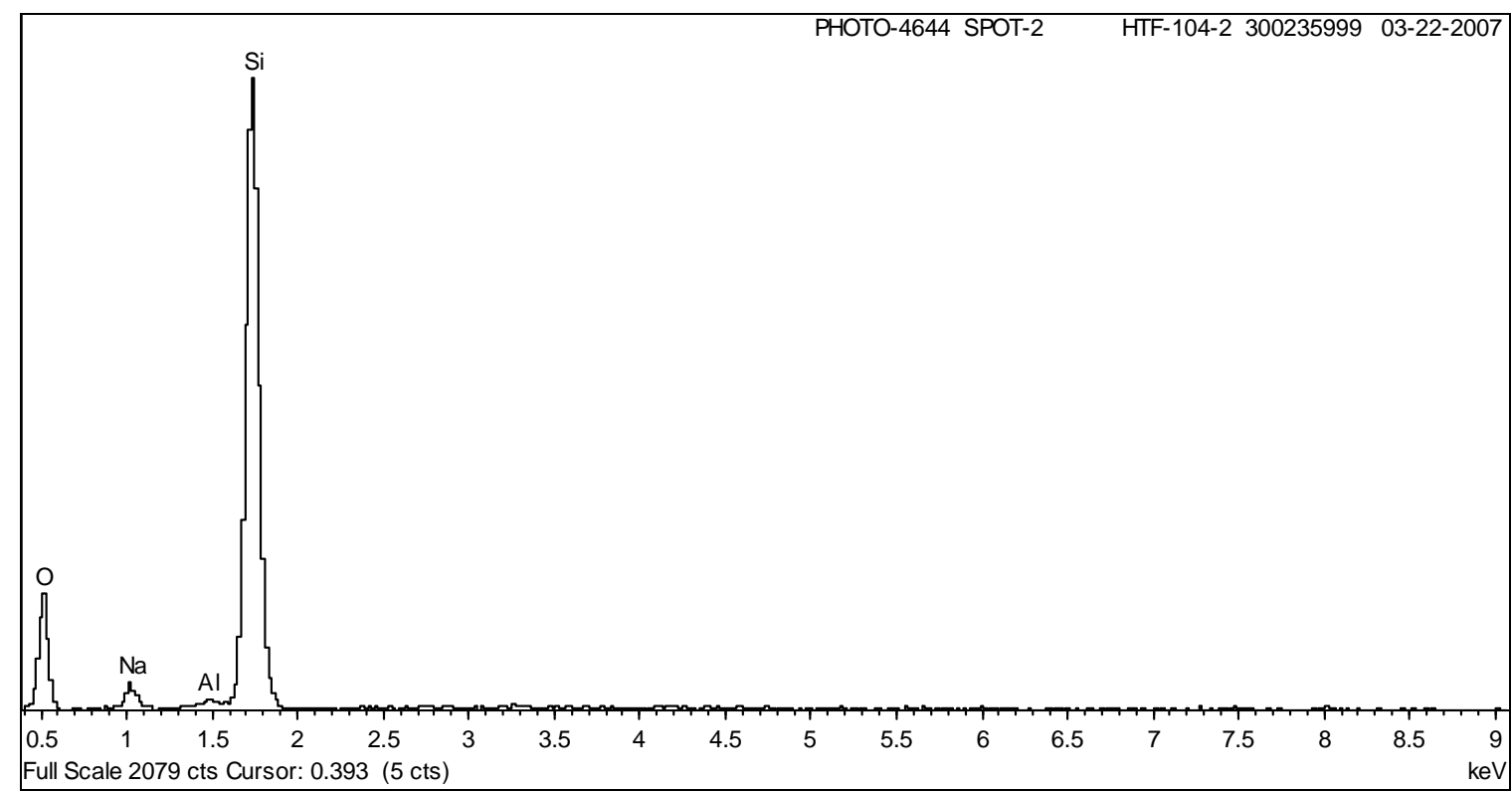

Figure 3.10 Spectrum of Spot 2 from Figure 3.8

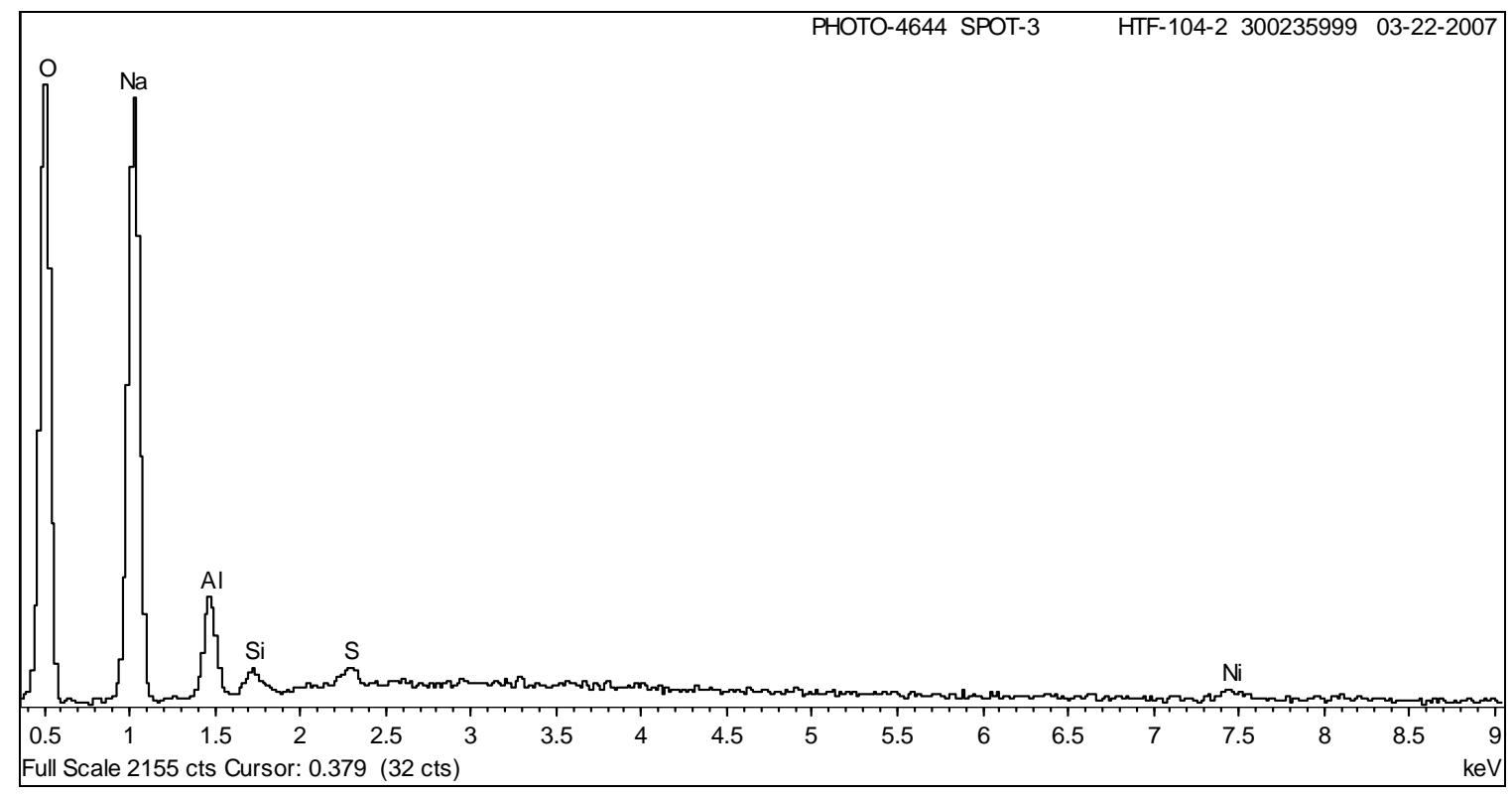

Figure 3.11 Spectrum of Spot 3 from Figure 3.8 


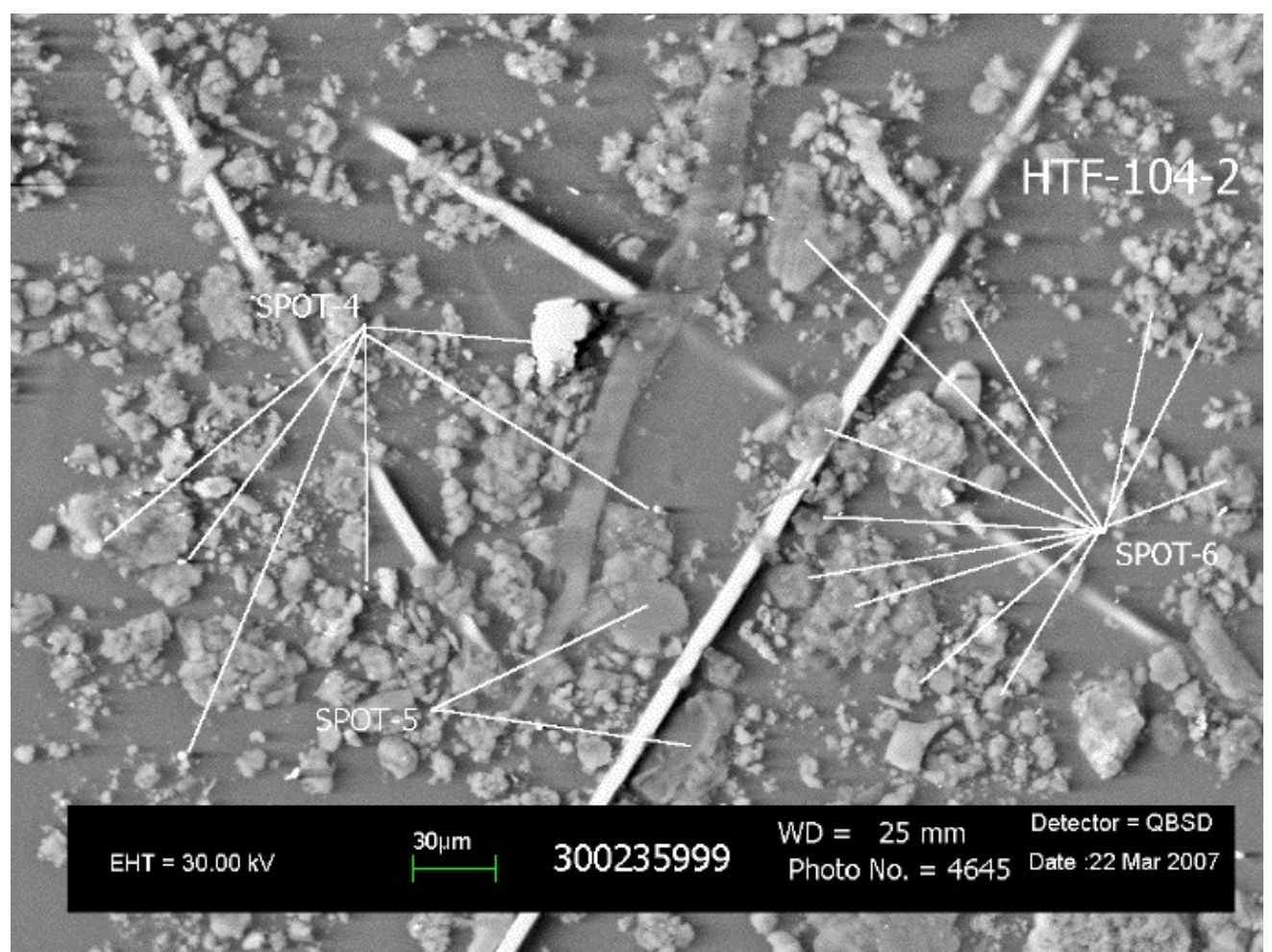

Figure 3.12 SEM Micrograph of Solids from Tank 16H Sample HTF-16-06-104-2 (250X Magnification)

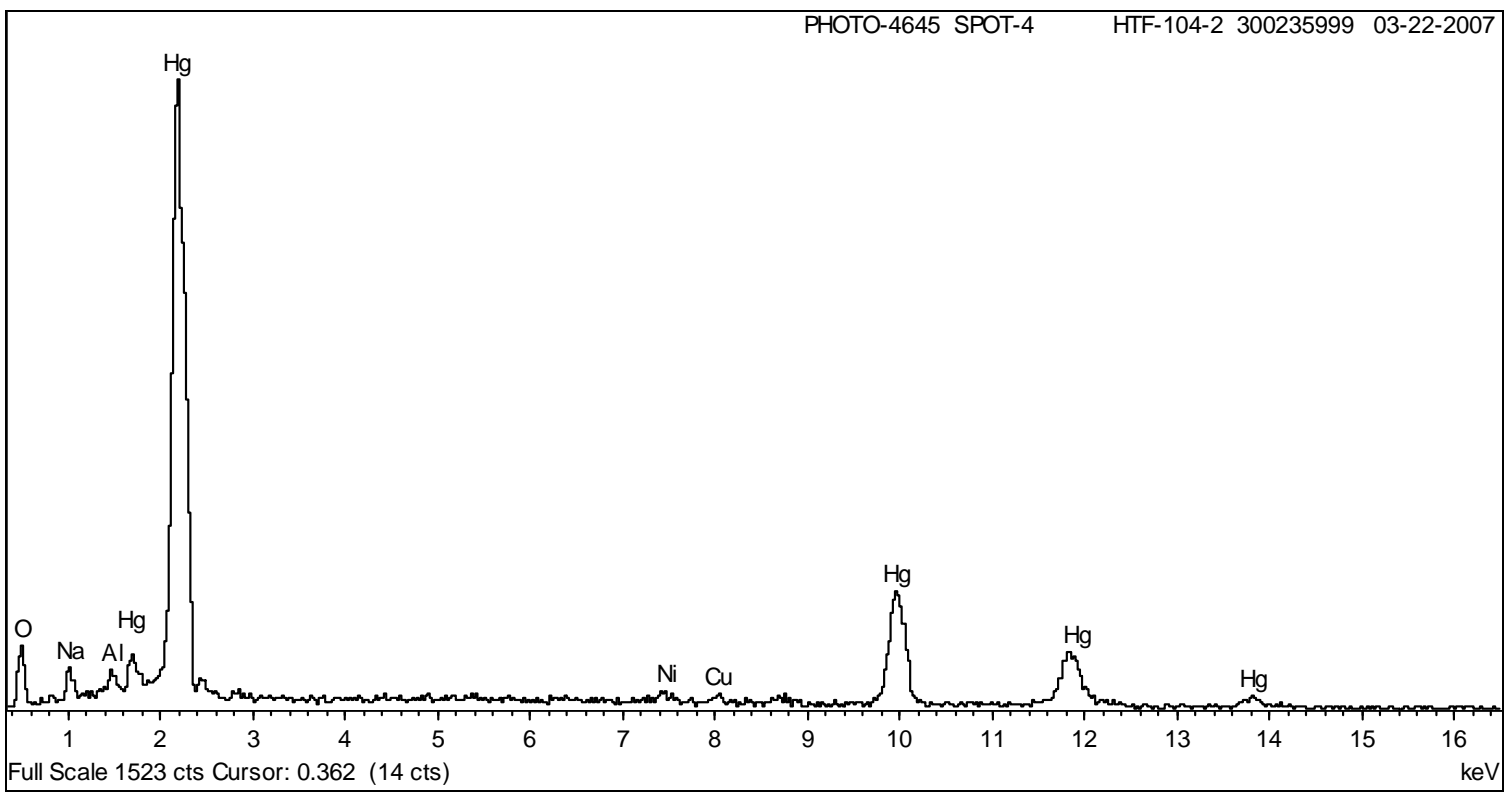

Figure 3.13 Spectrum of Spot 4 from Figure 3.12 
WSRC-STI-2008-00203, REV. 0

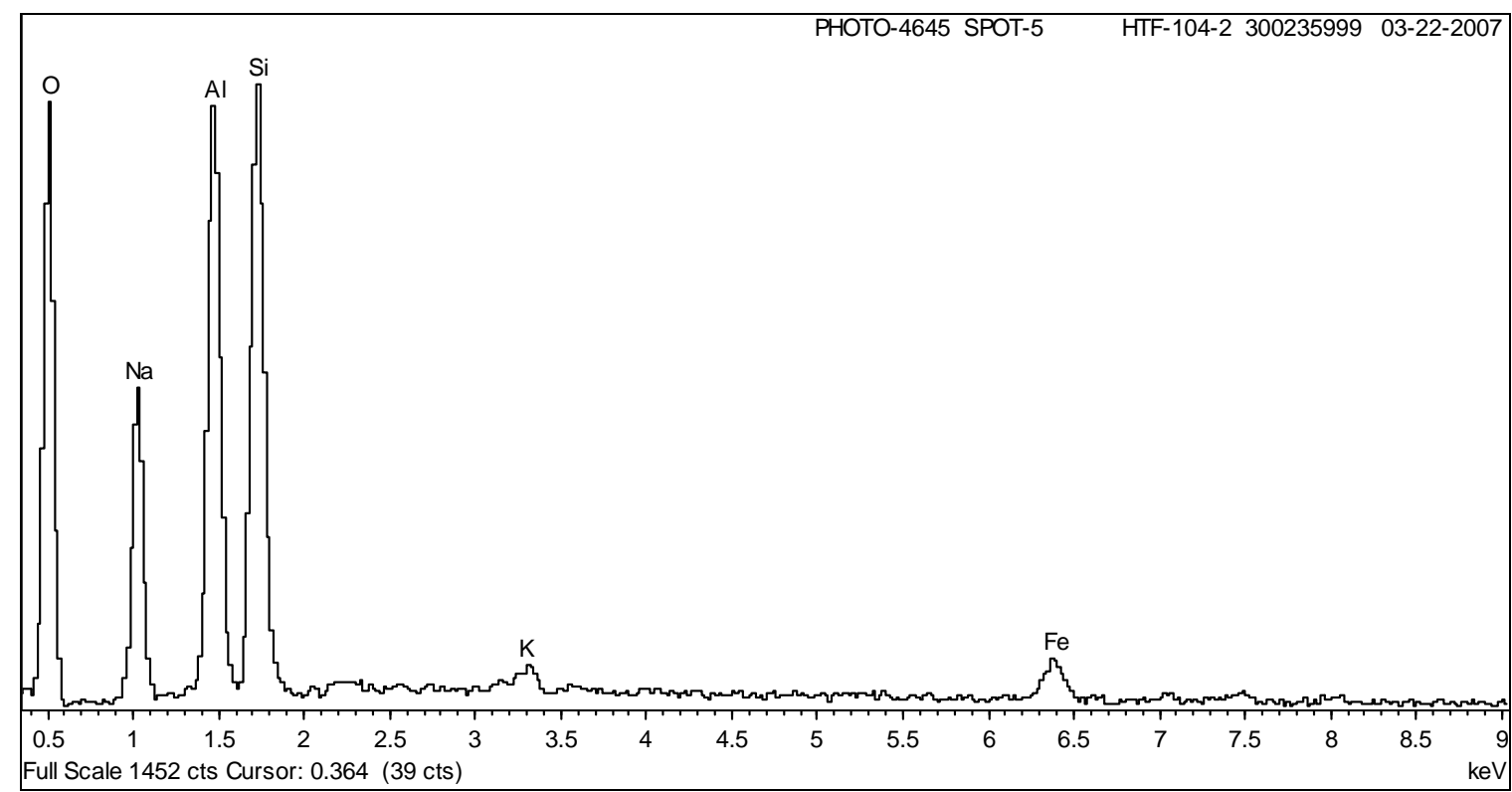

Figure 3.14 Spectrum of Spot 5 from Figure 3.12

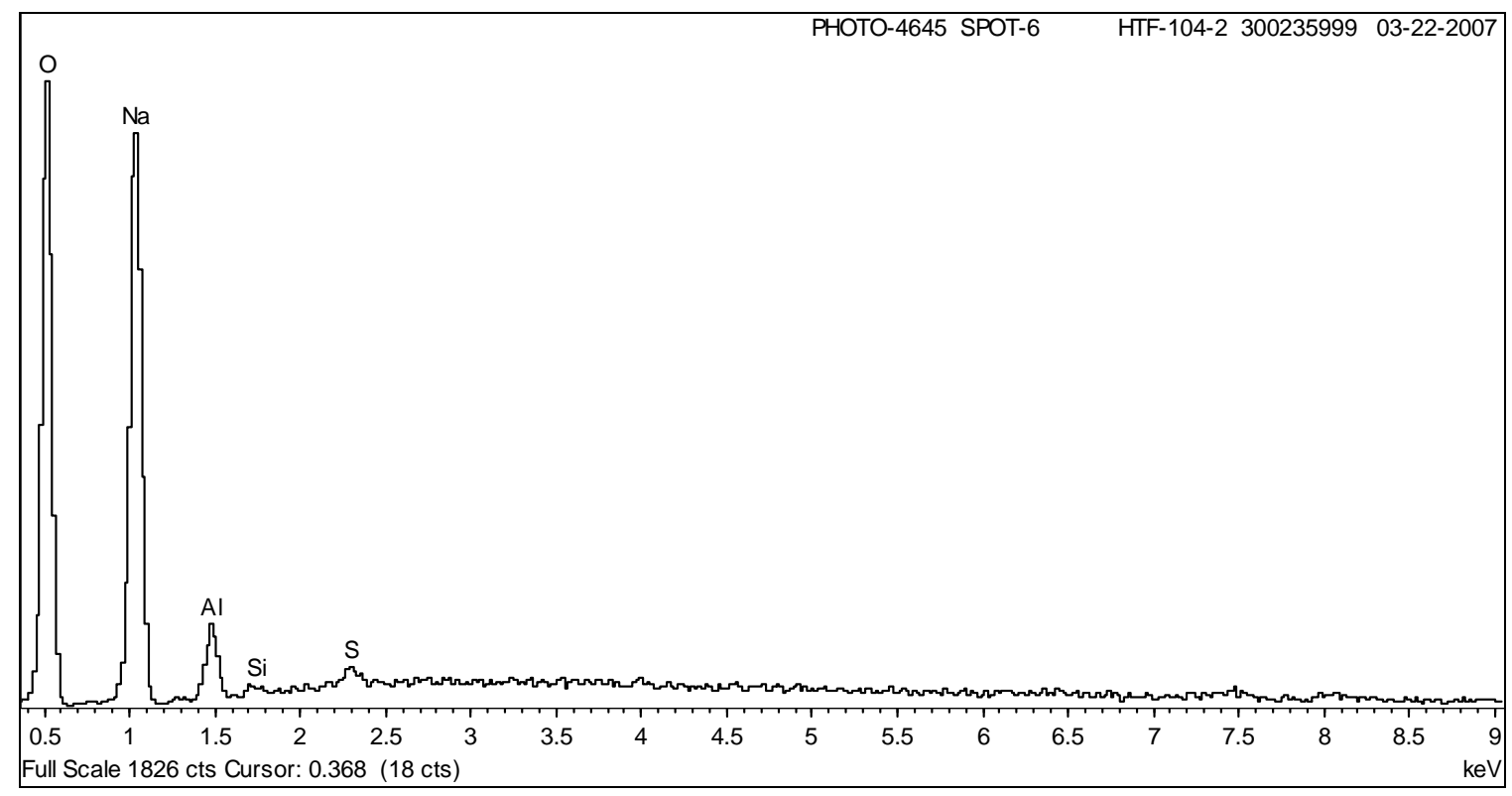

Figure 3.15 Spectrum of Spot 6 from Figure 3.12 


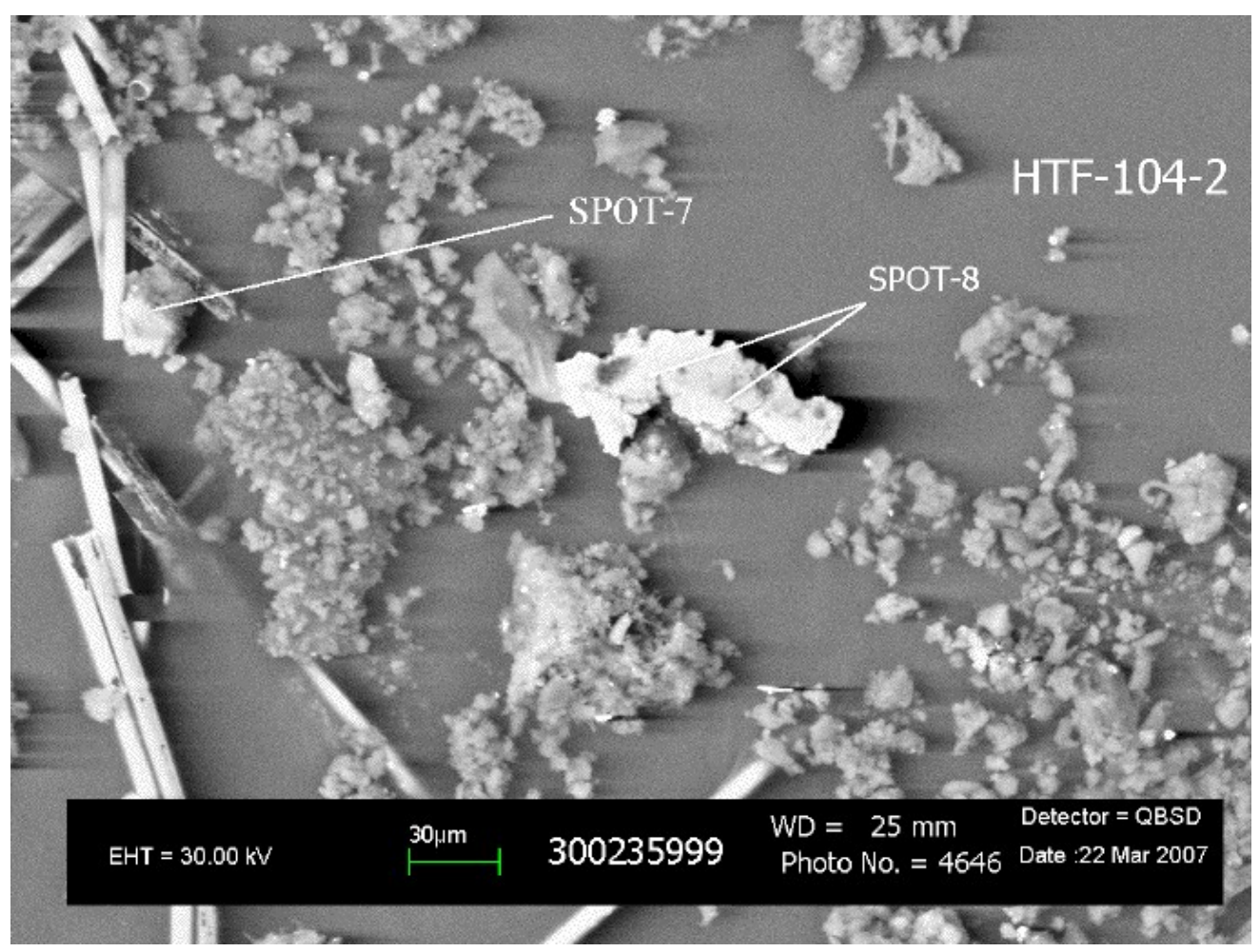

Figure 3.16 SEM Micrograph of Solids from Tank 16H Sample HTF-16-06-104-2 (277X Magnification)

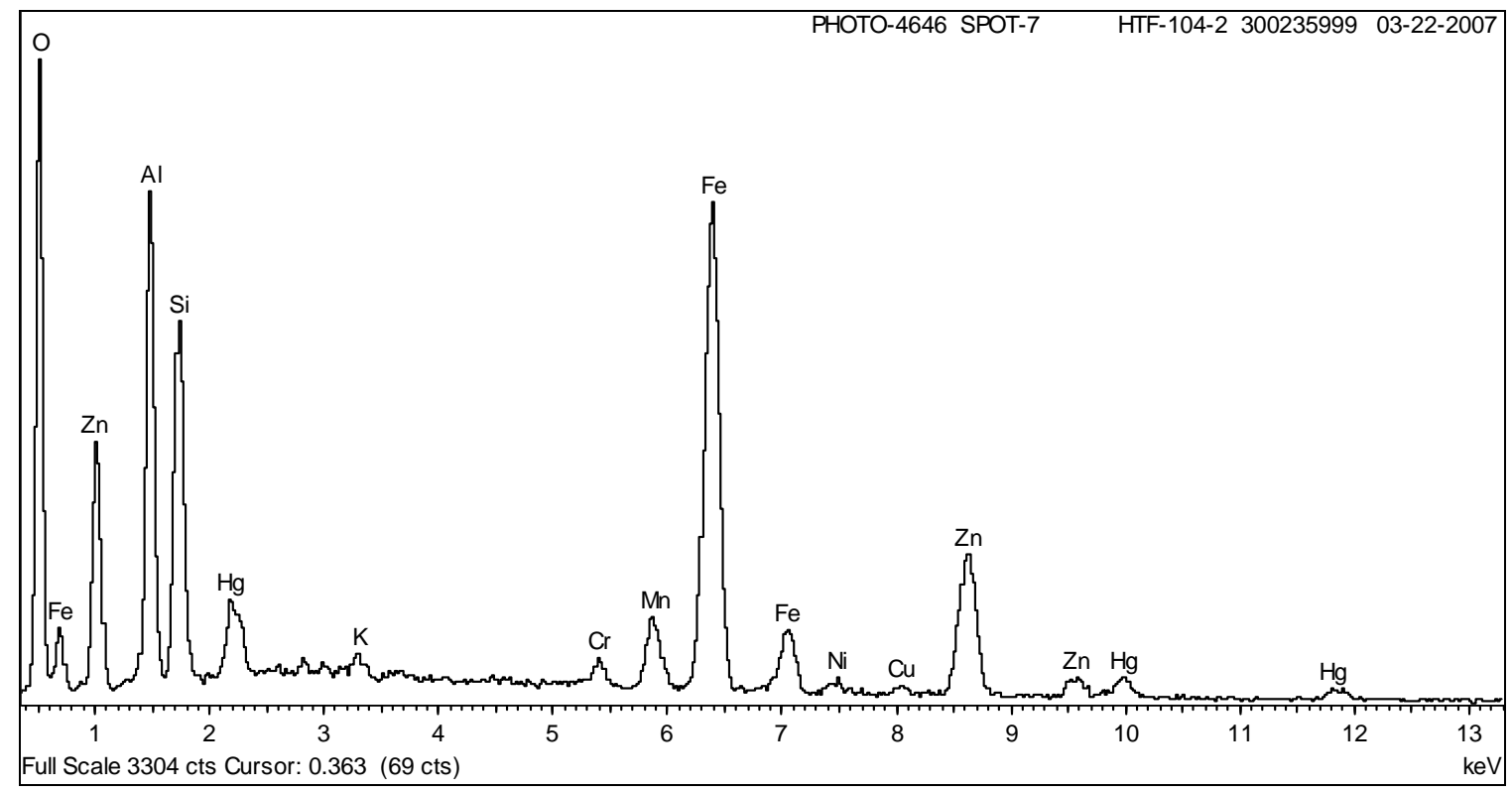

Figure 3.17 Spectrum of Spot 7 from Figure 3.16 
WSRC-STI-2008-00203, REV. 0

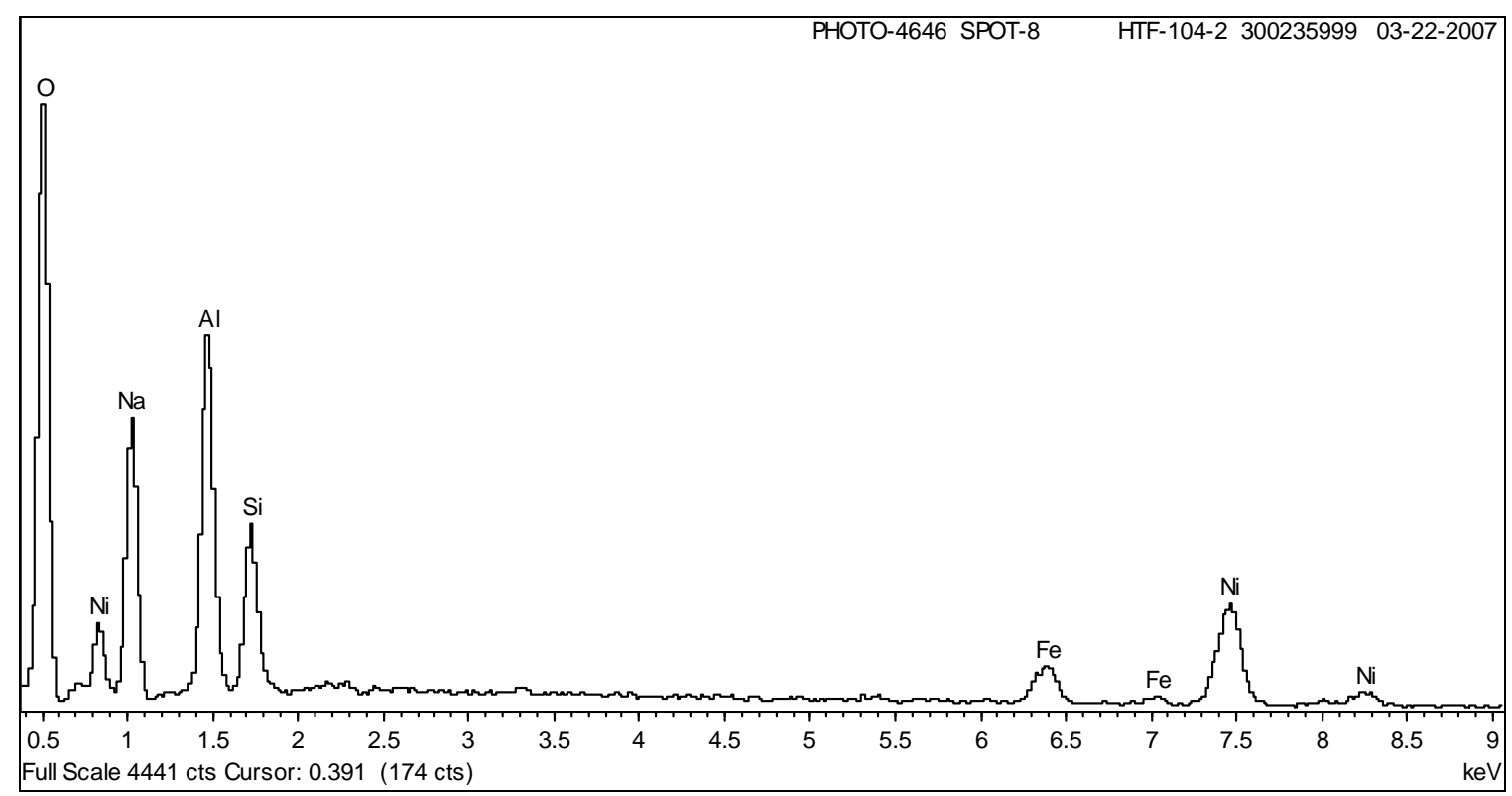

Figure 3.18 Spectrum of Spot 8 from Figure 3.16 


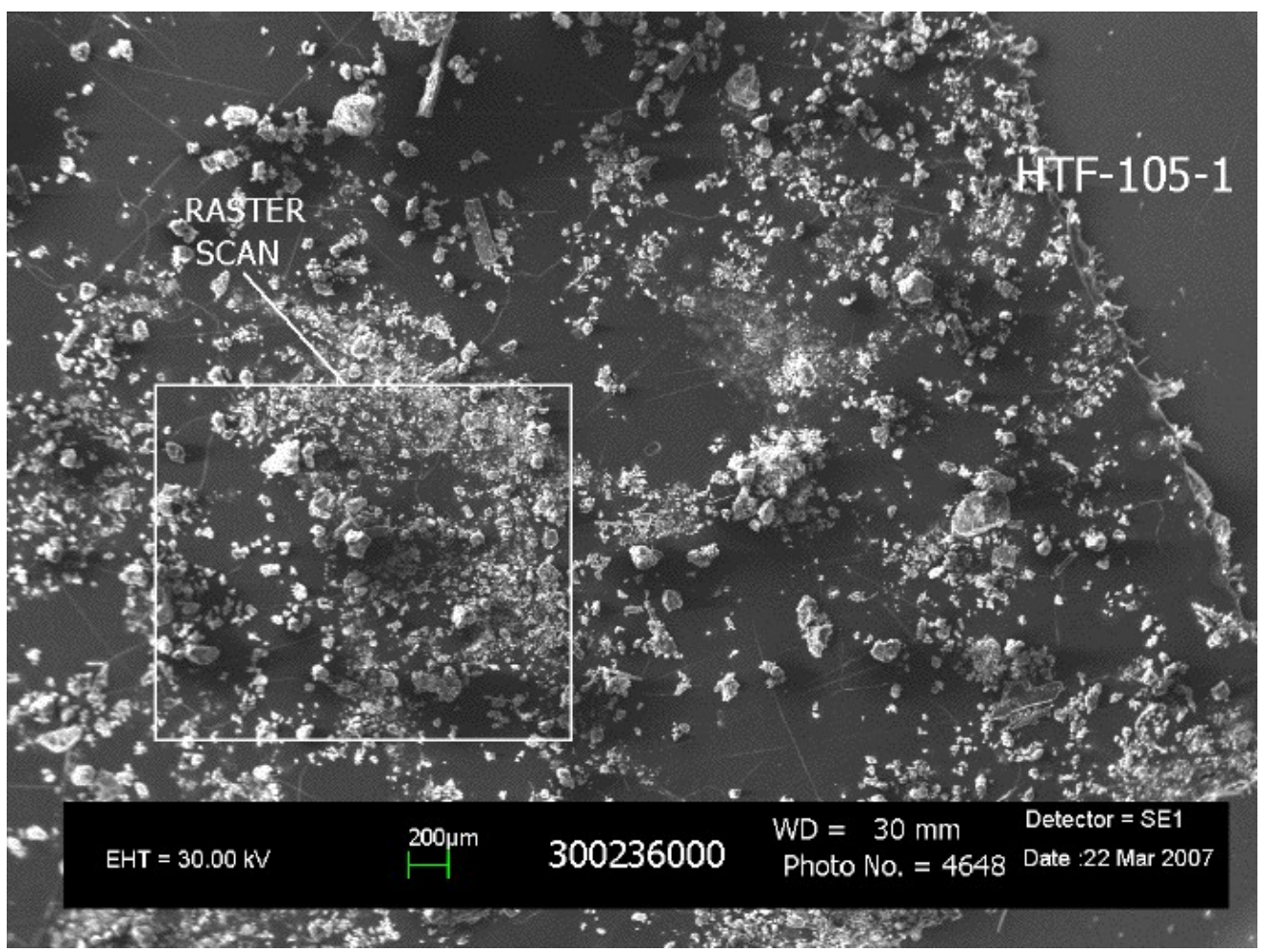

Figure 3.19 SEM Micrograph of Solids from Tank 16H Sample HTF-16-06-105-1 (18X Magnification)

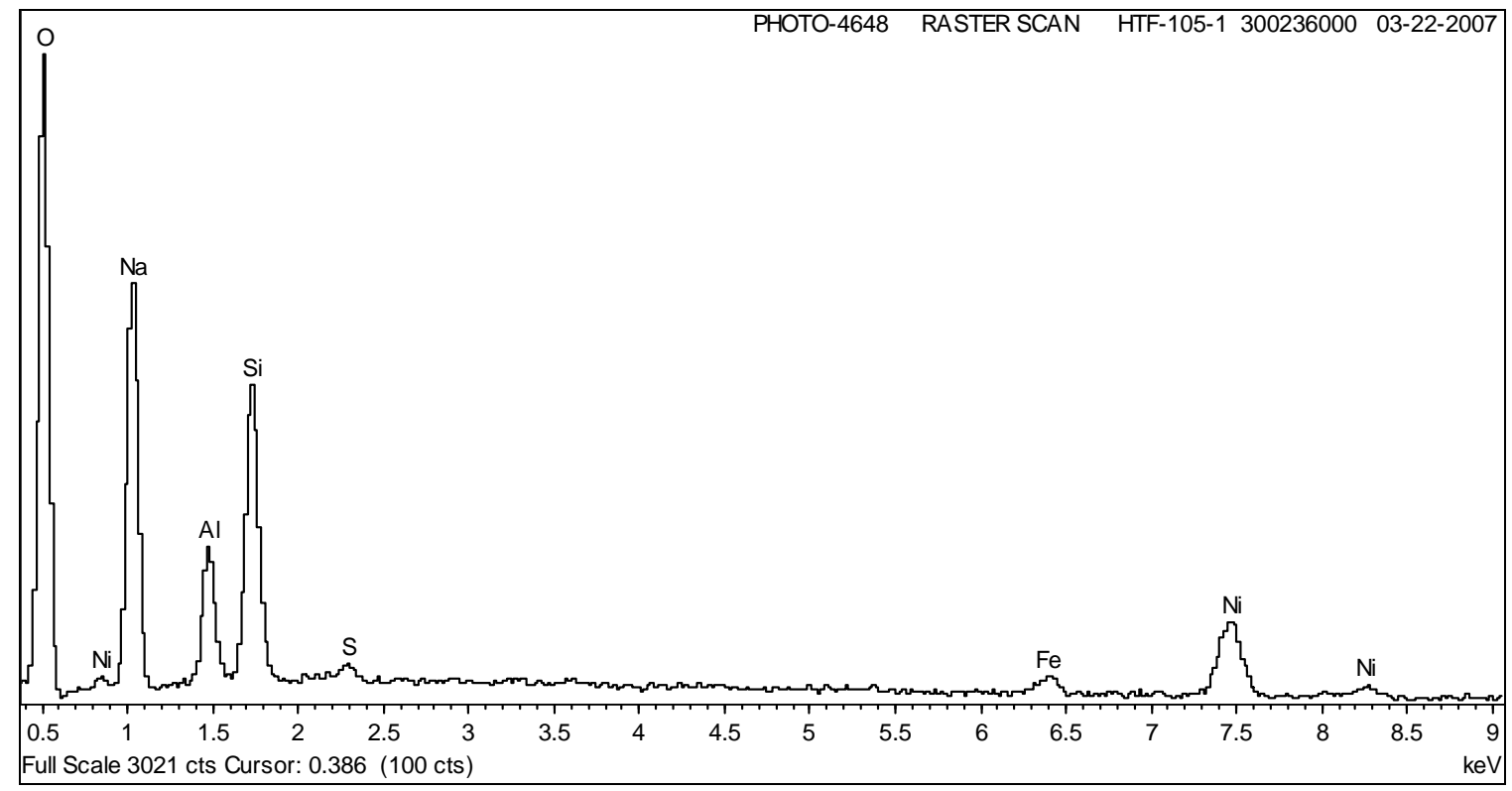

Figure 3.20 Spectrum of Raster Scan from Figure 3.19 


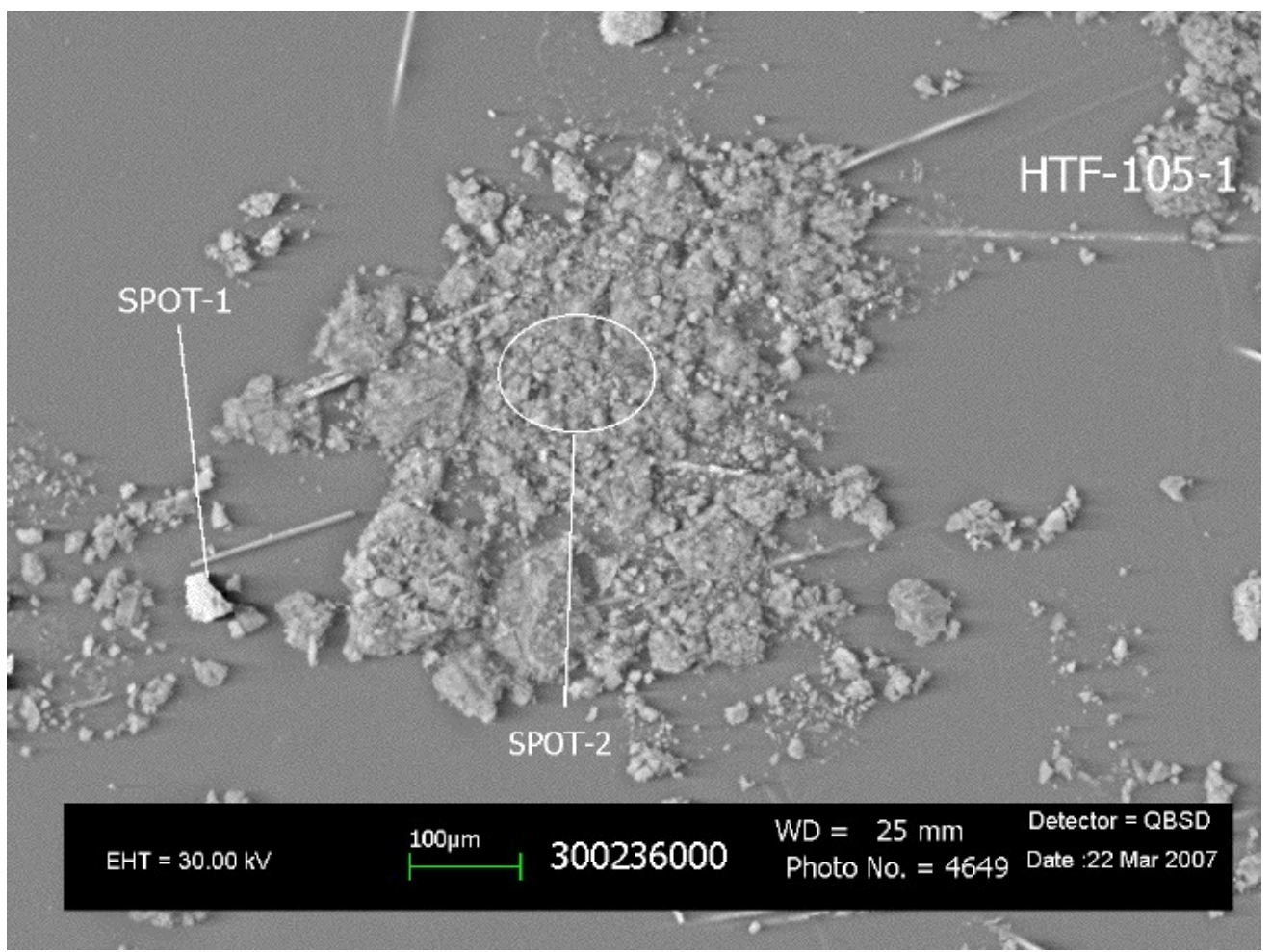

Figure 3.21 SEM Micrograph of Solids from Tank 16H Sample HTF-16-06-105-1 (100X Magnification)

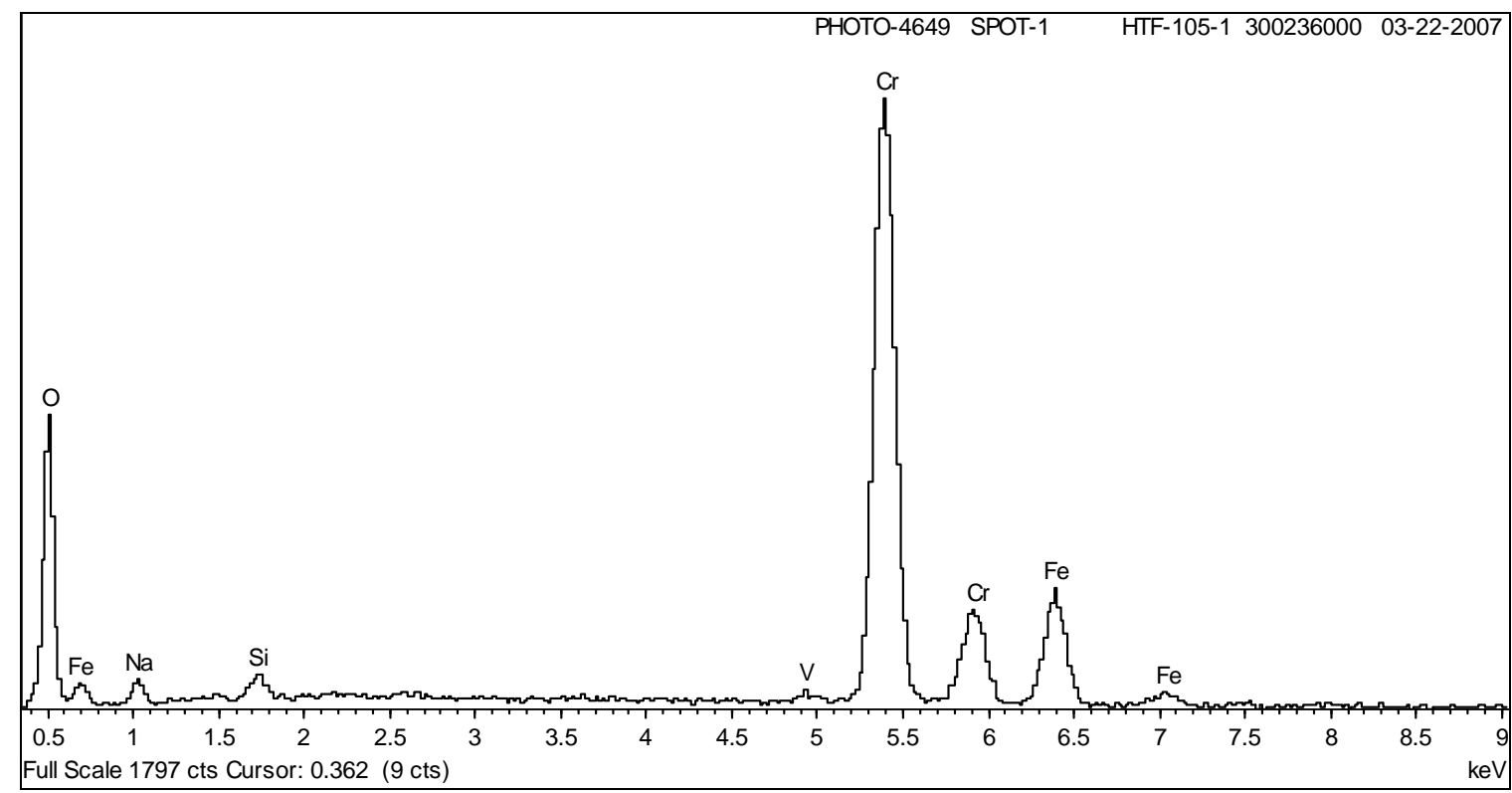

Figure 3.22 Spectrum of Spot 1 from Figure 3.21 
WSRC-STI-2008-00203, REV. 0

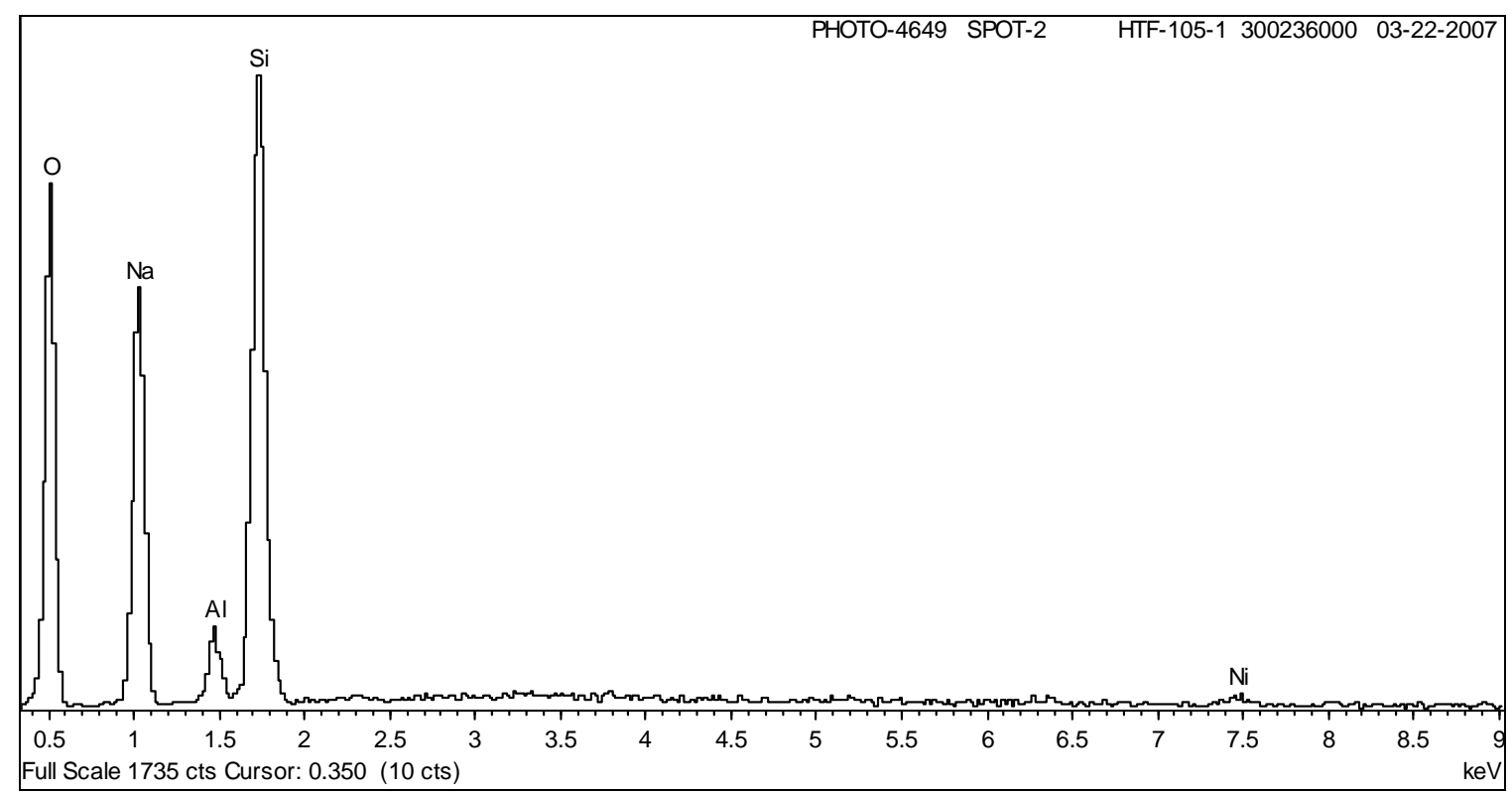

Figure 3.23 Spectrum of Spot 2 from Figure 3.21 


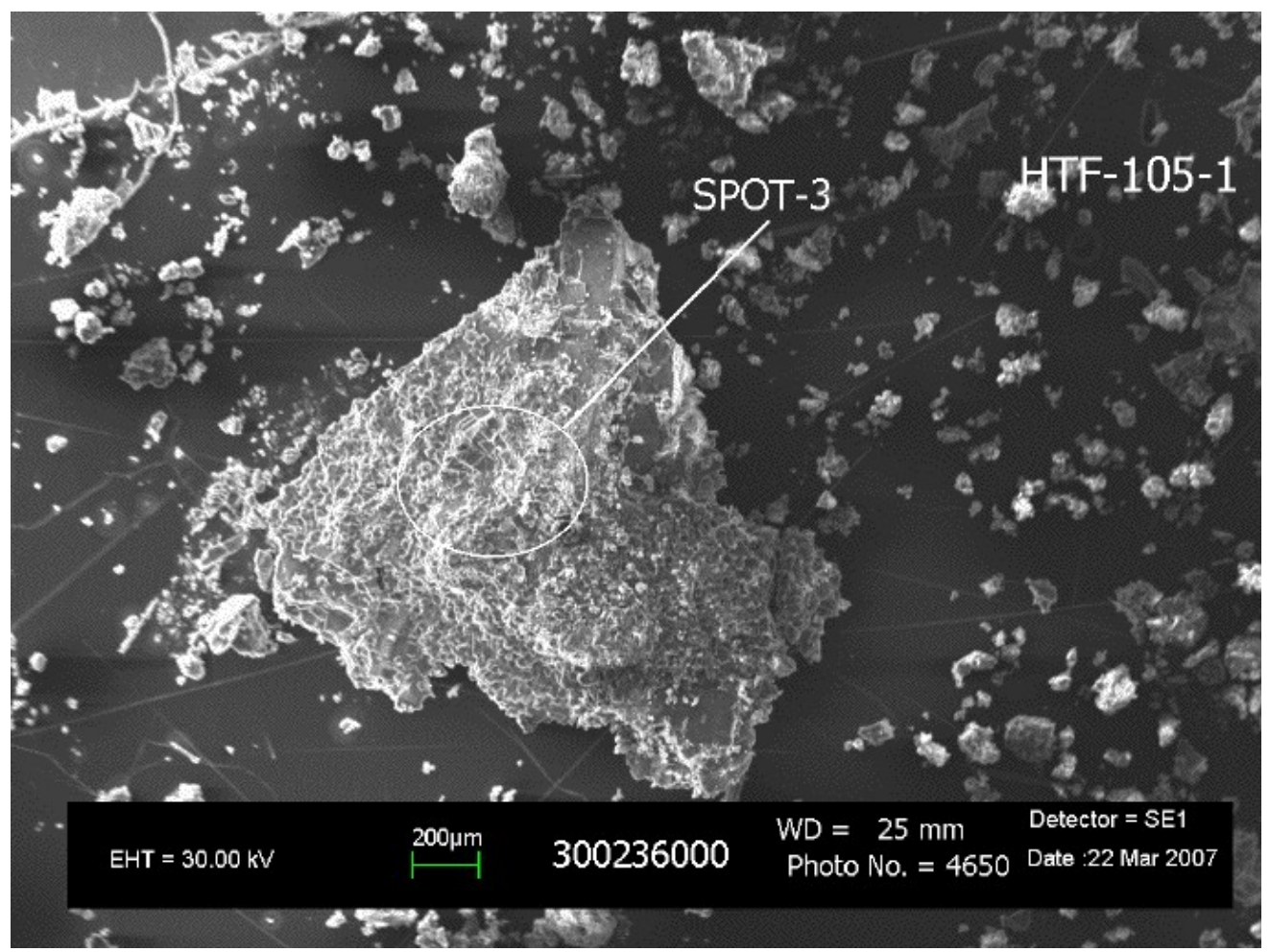

Figure 3.24 SEM Micrograph of Solids from Tank 16H Sample HTF-16-06-105-1 (30X Magnification)

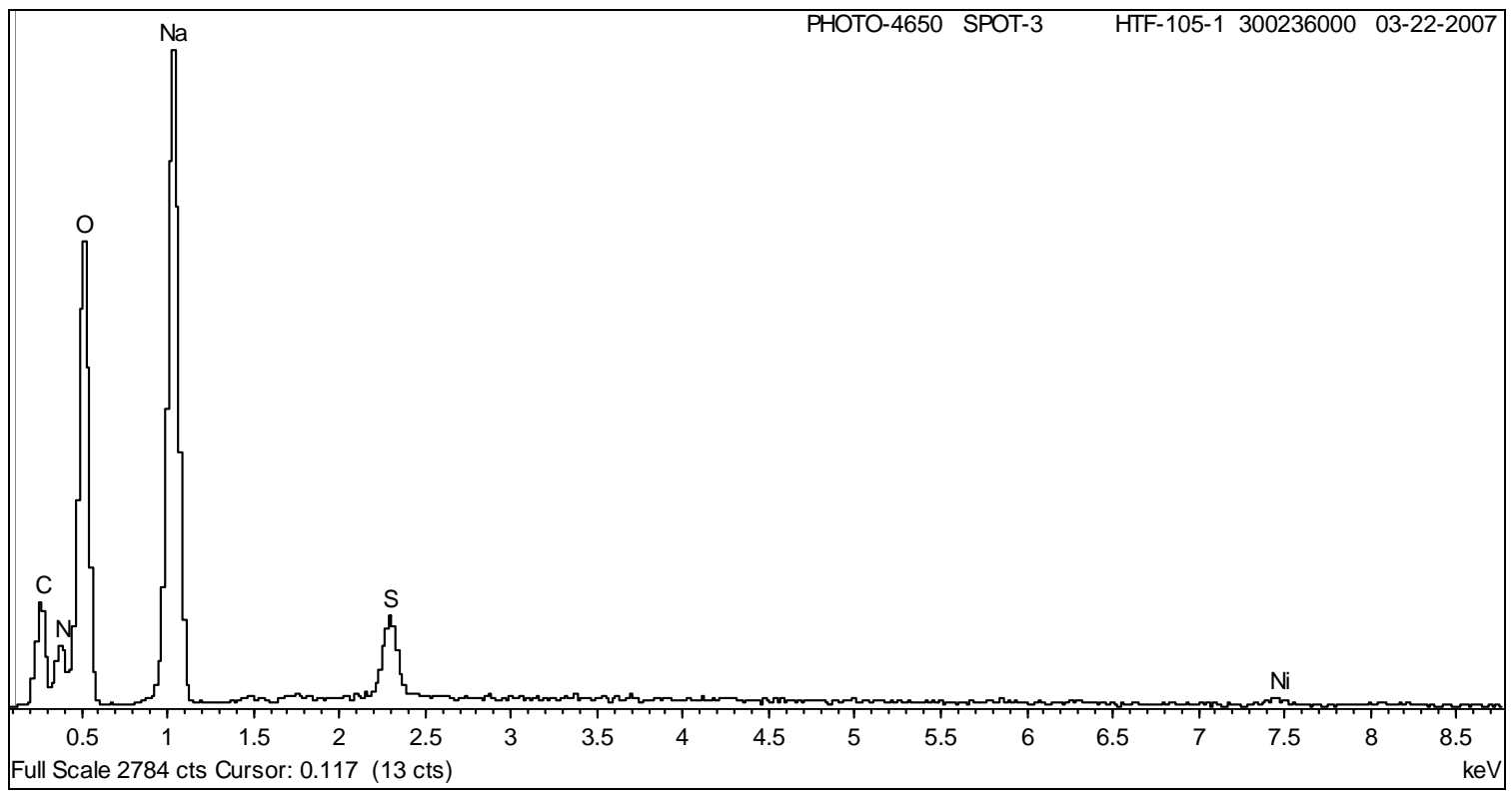

Figure 3.25 Spectrum of Spot 3 from Figure 3.24 


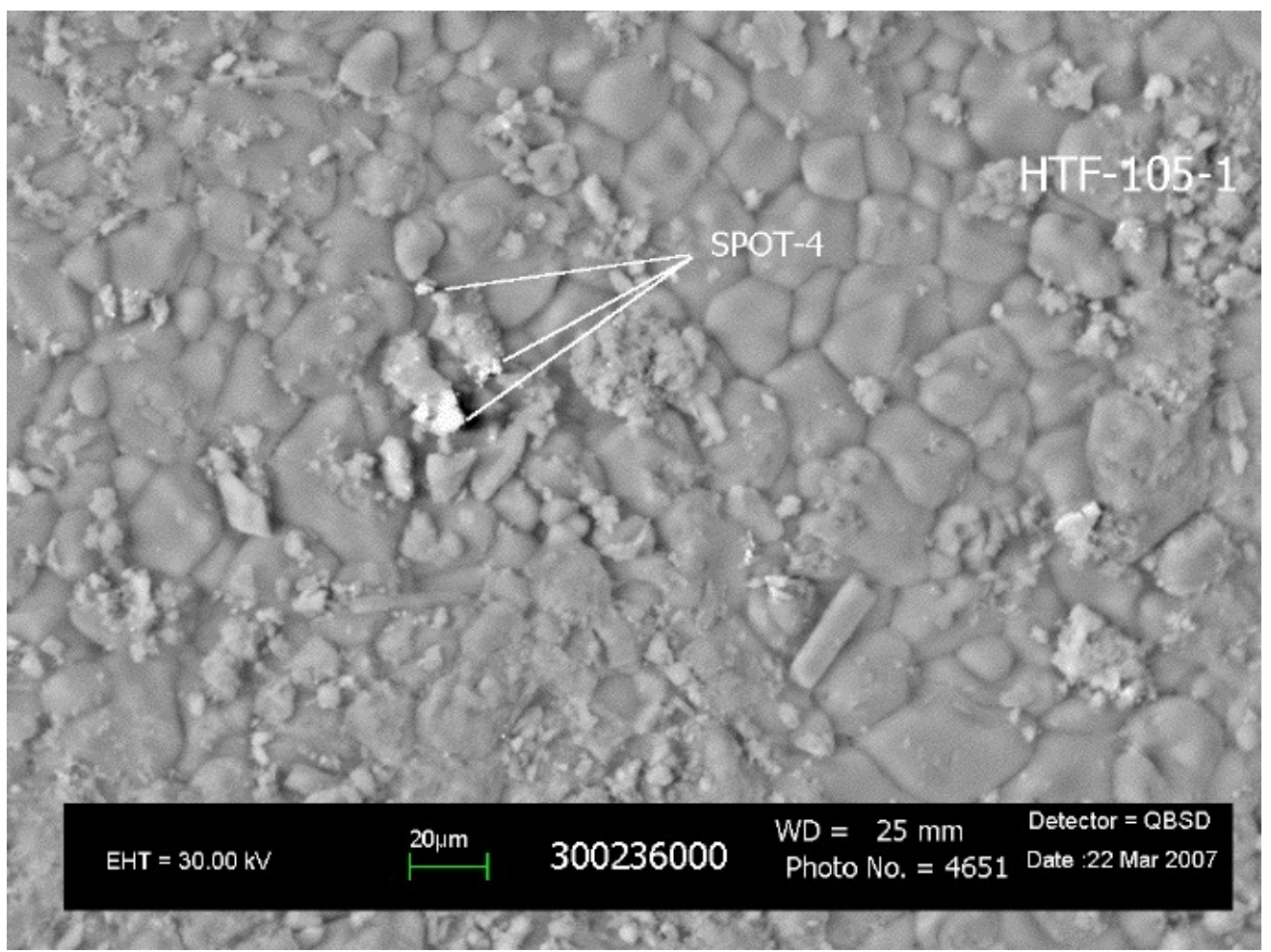

Figure 3.26 SEM Micrograph of Solids from Tank 16H Sample HTF-16-06-105-1 (350X Magnification)

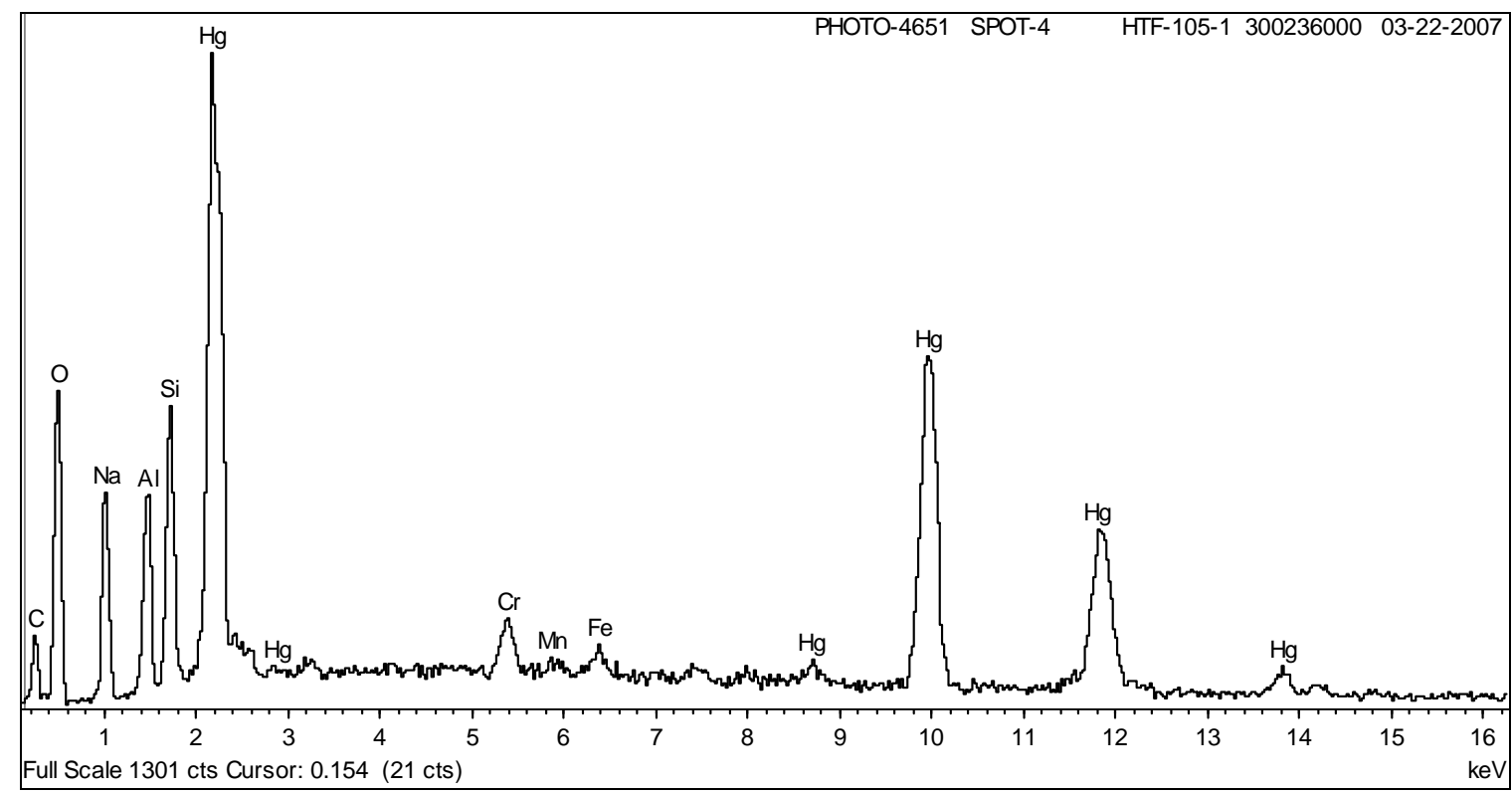

Figure 3.27 Spectrum of Spot 4 from Figure 3.26 


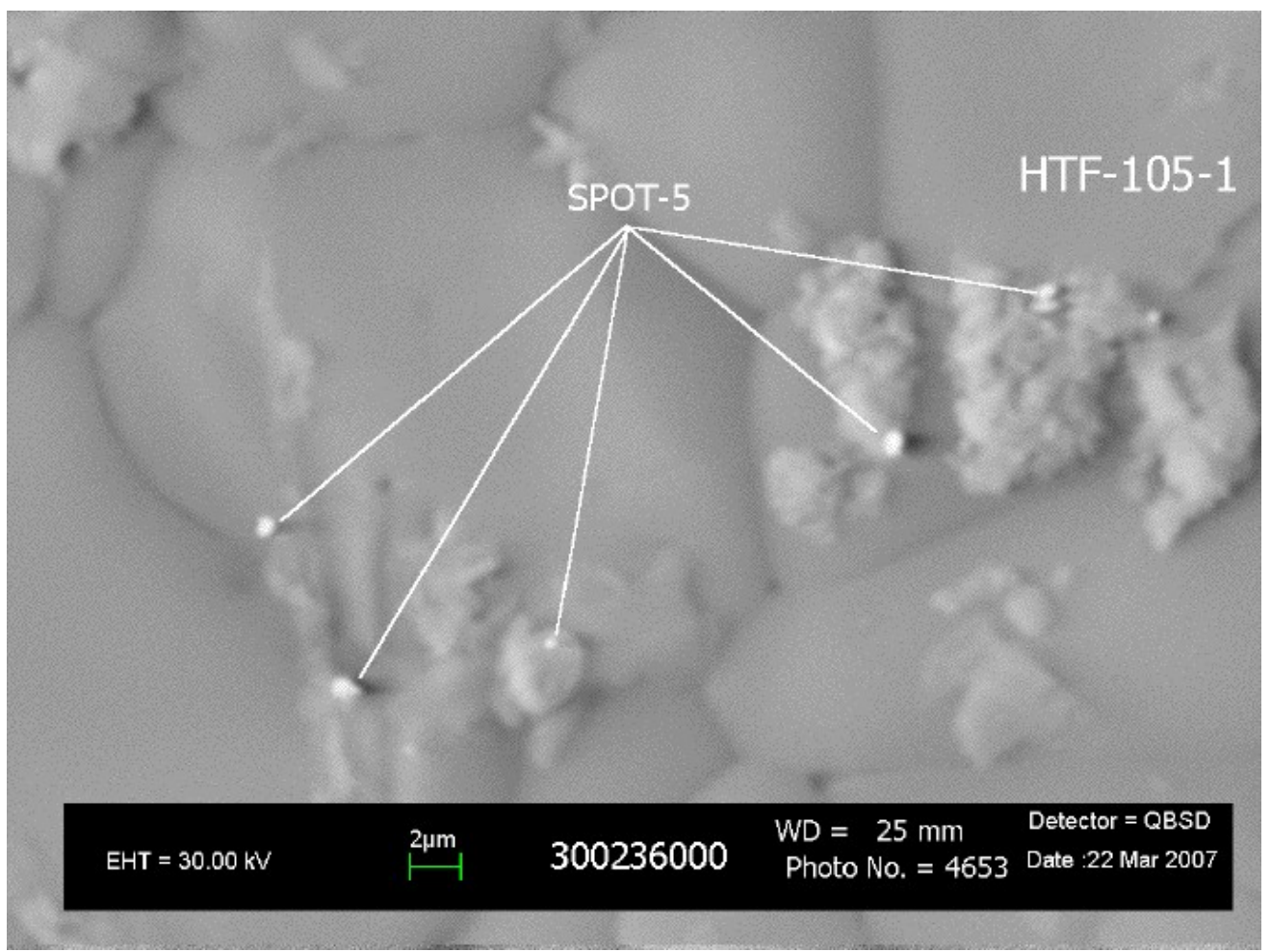

Figure 3.28 SEM Micrograph of Solids from Tank 16H Sample HTF-16-06-105-1 (350X Magnification)

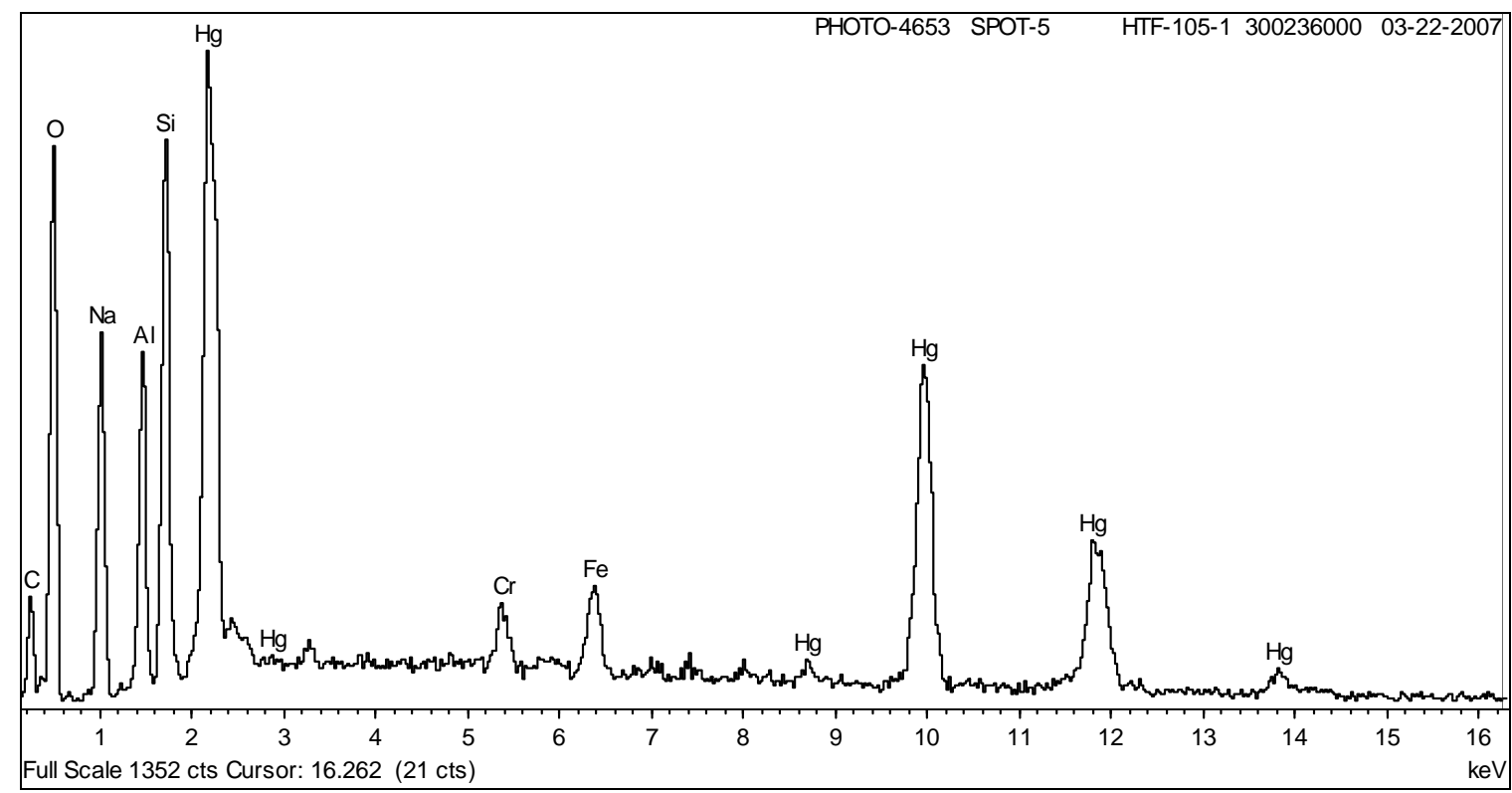

Figure 3.29 Spectrum of Spot 5 from Figure 3.28 


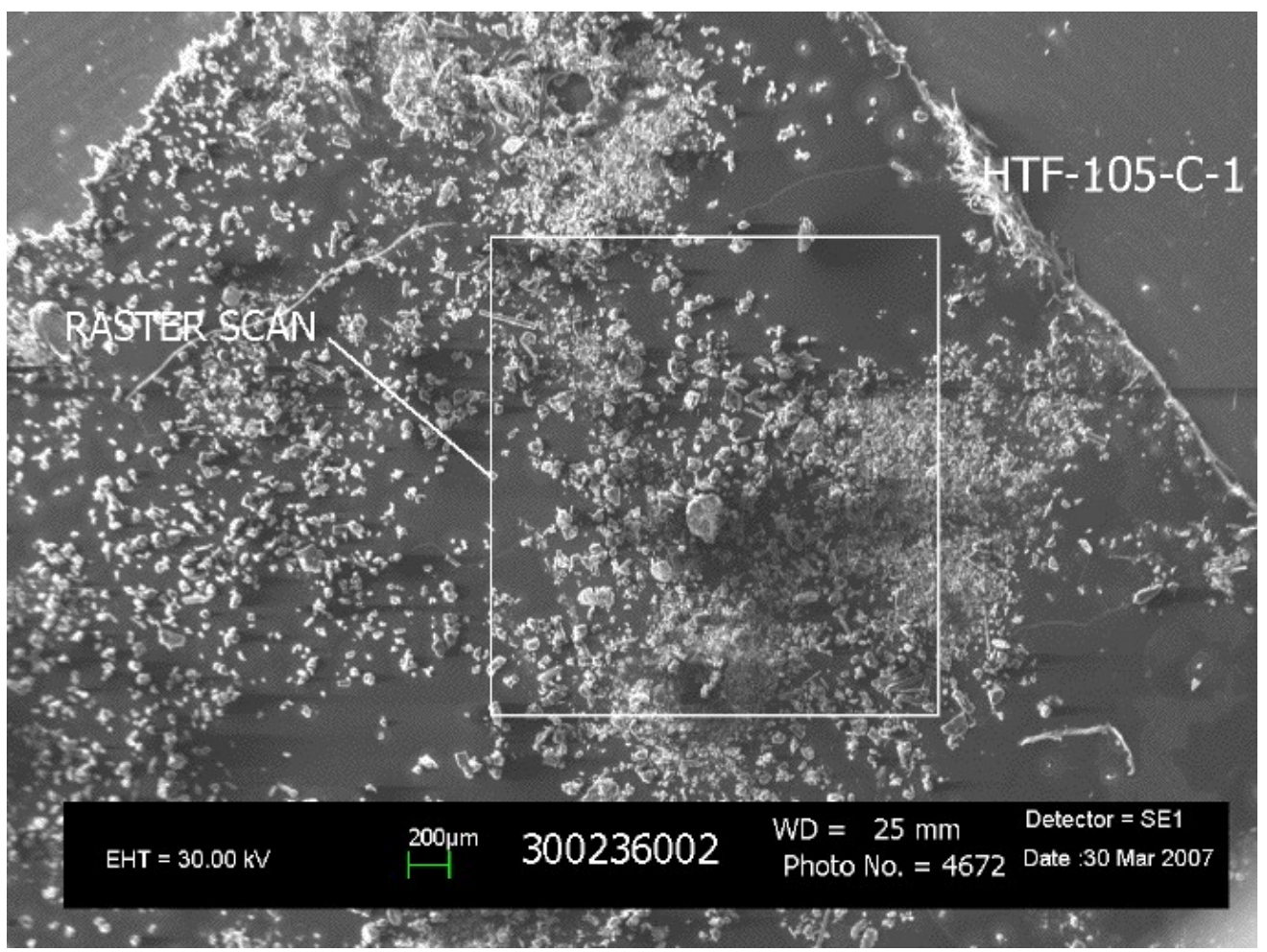

Figure 3.30 SEM Micrograph of Solids from Tank 16H Sample HTF-16-06-105C-1 (18X Magnification)

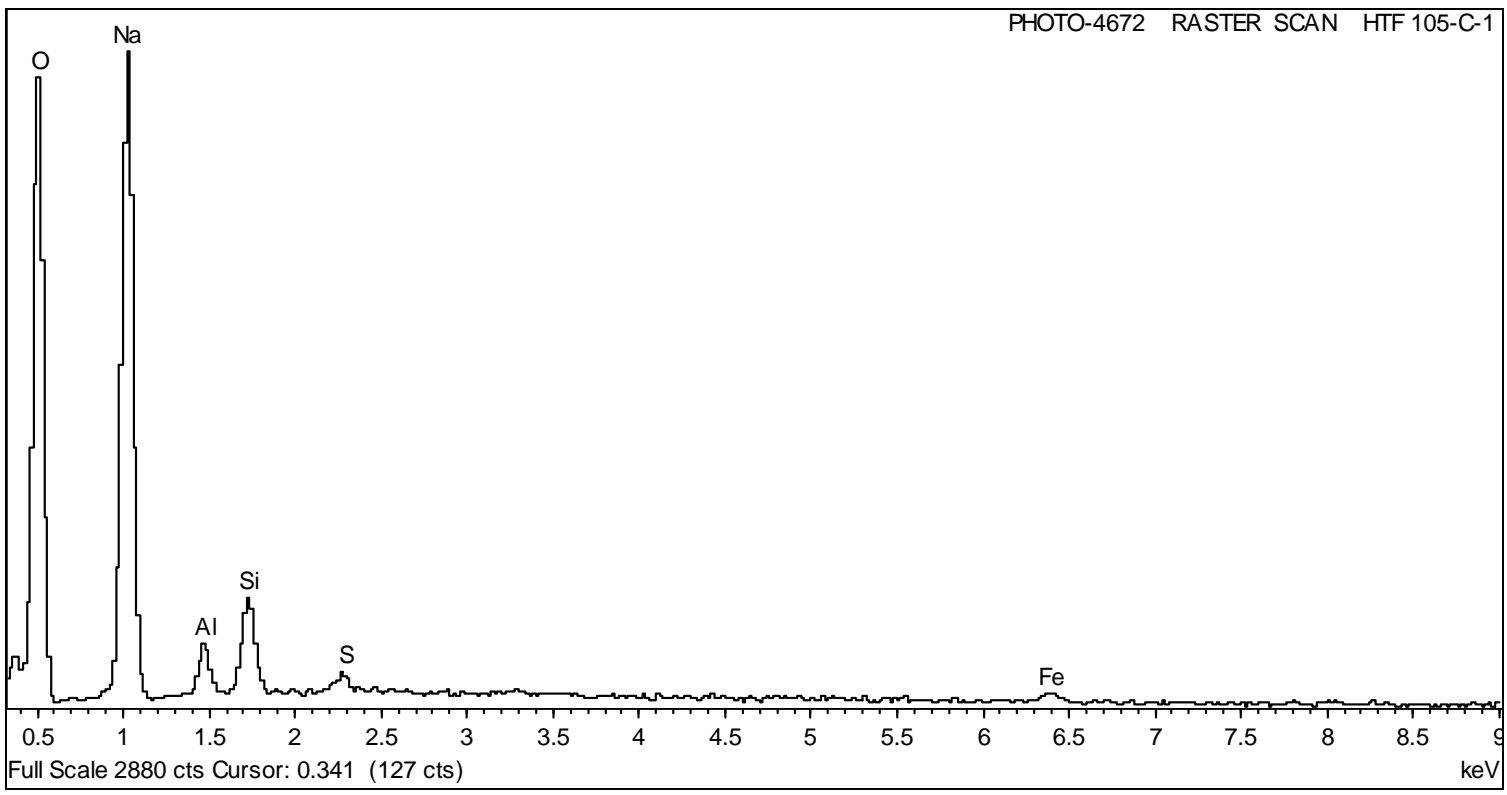

Figure 3.31 Spectrum of Raster Scan from Figure 3.30 


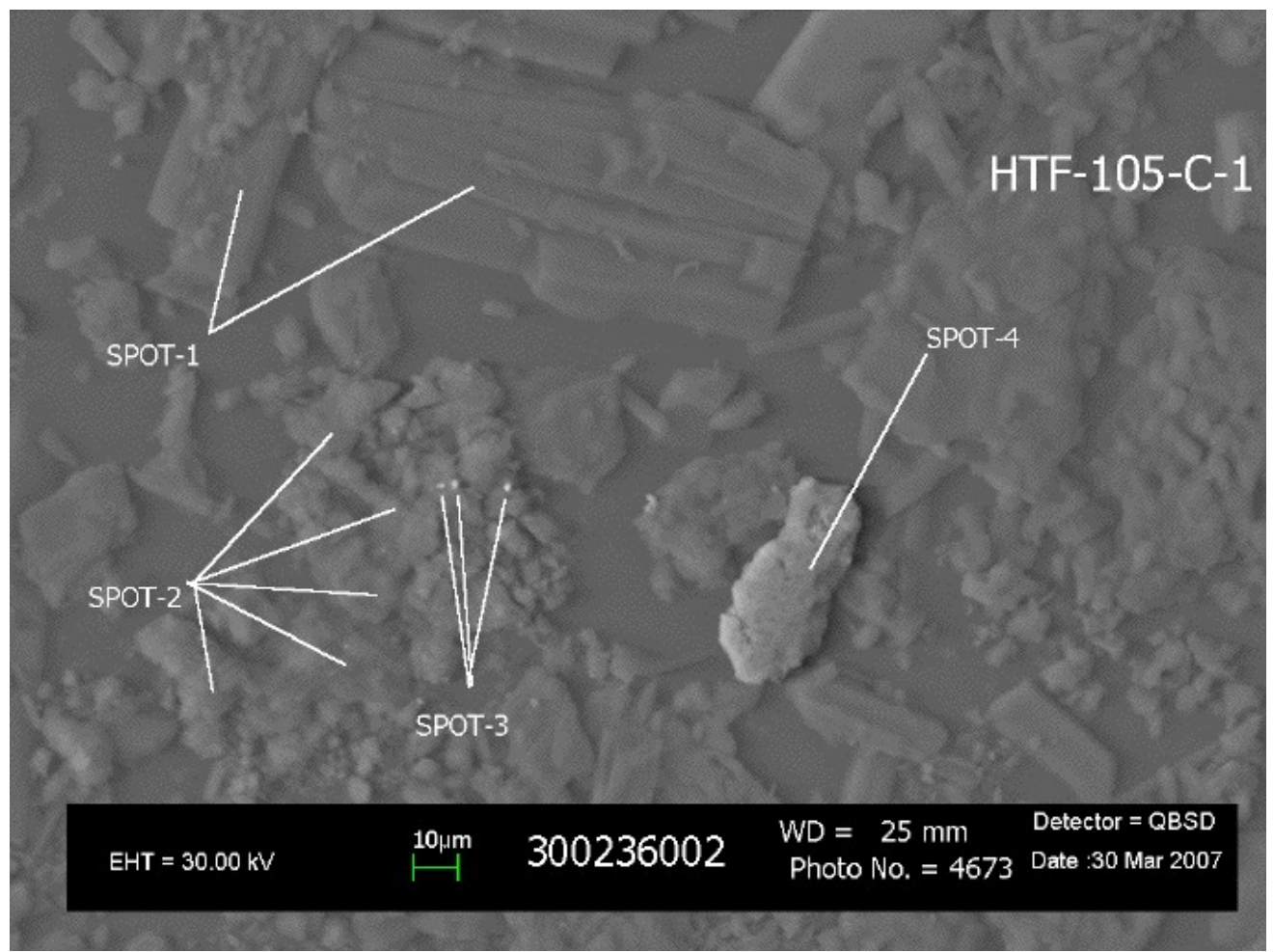

Figure 3.32 SEM Micrograph of Solids from Tank 16H Sample HTF-16-06-105C-1 (400X Magnification)

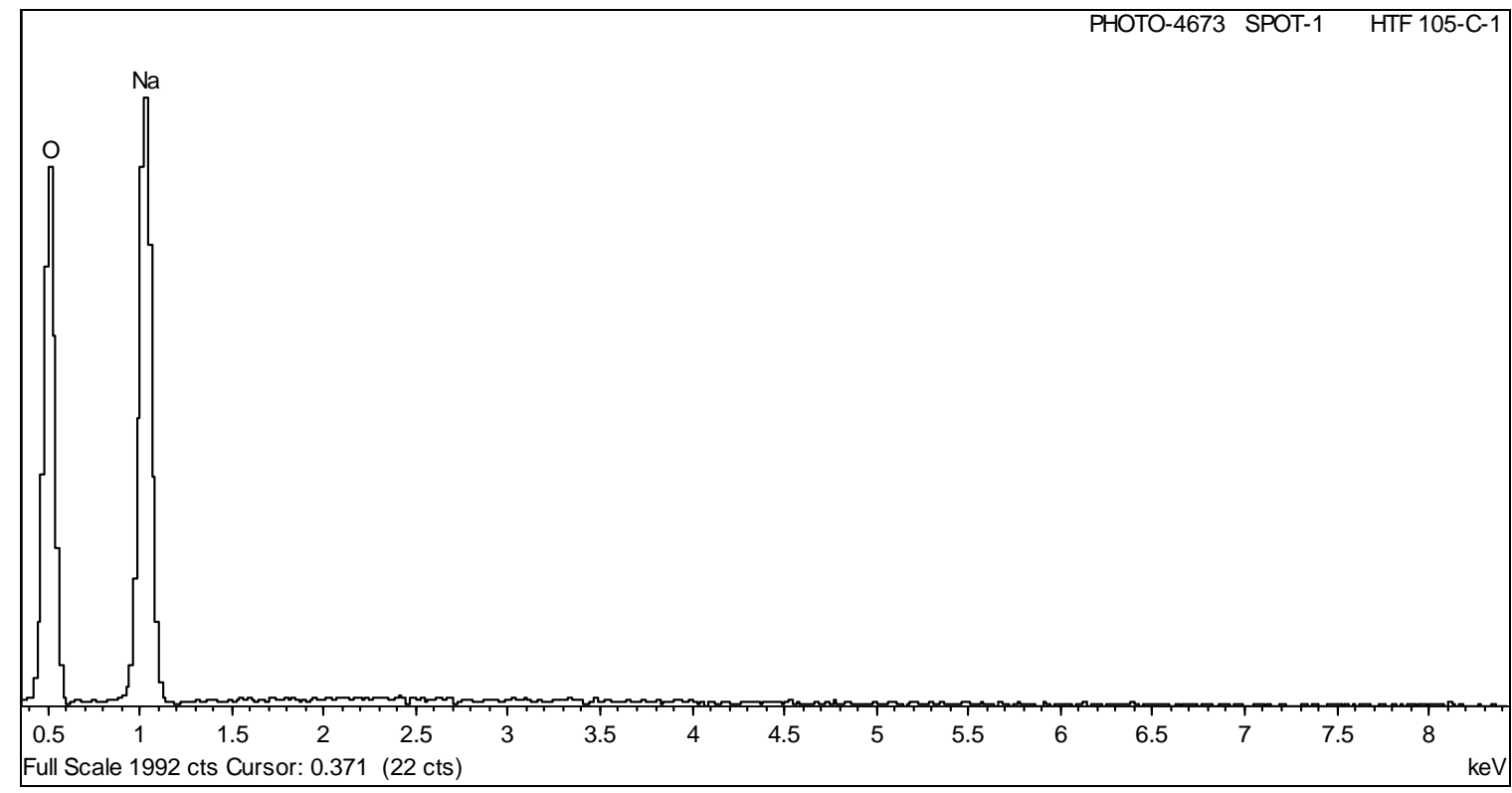

Figure 3.33 Spectrum of Spot 1 from Figure 3.32 
WSRC-STI-2008-00203, REV. 0

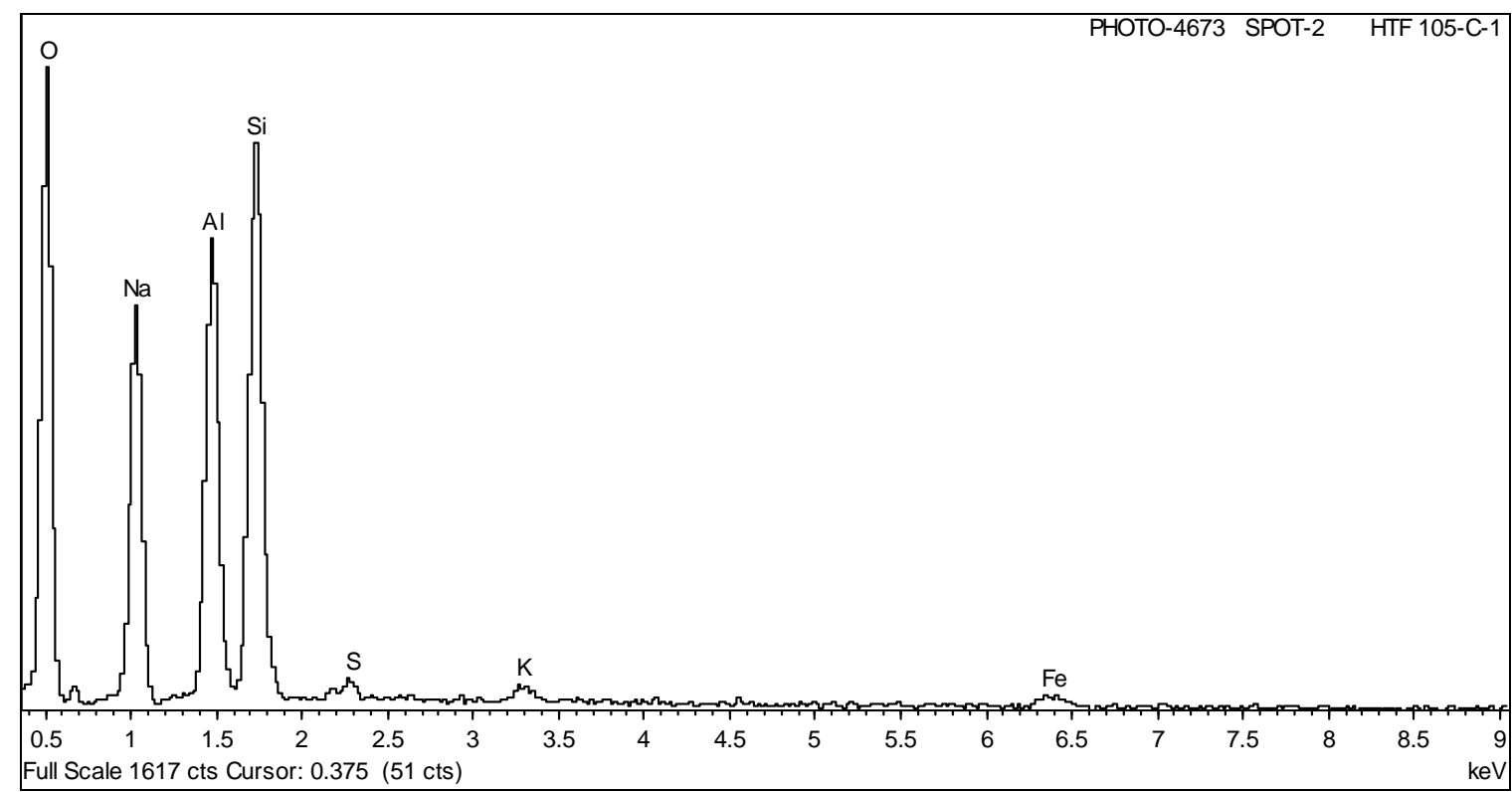

Figure 3.34 Spectrum of Spot 2 from Figure 3.32

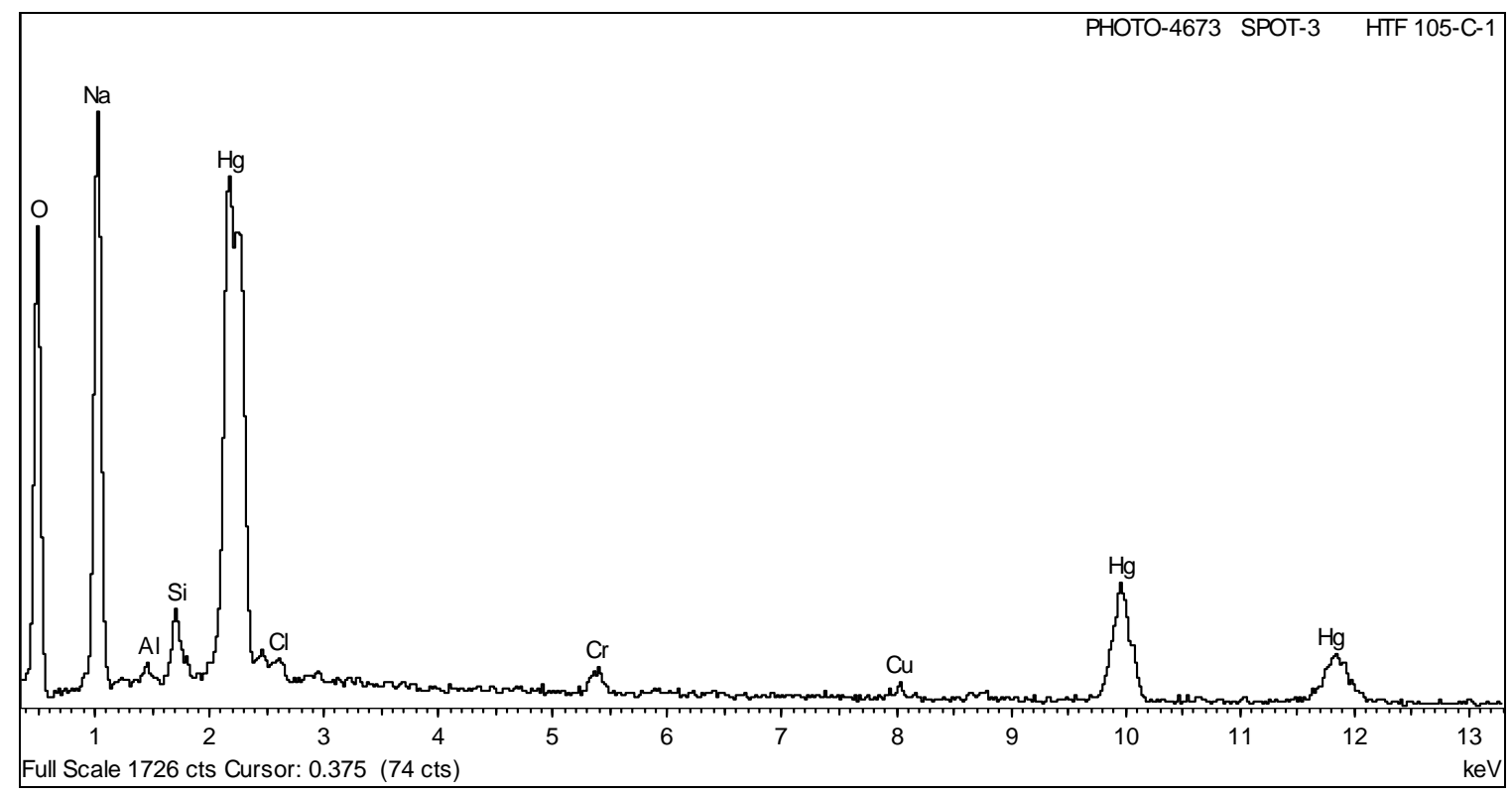

Figure 3.35 Spectrum of Spot 3 from Figure 3.32 
WSRC-STI-2008-00203, REV. 0

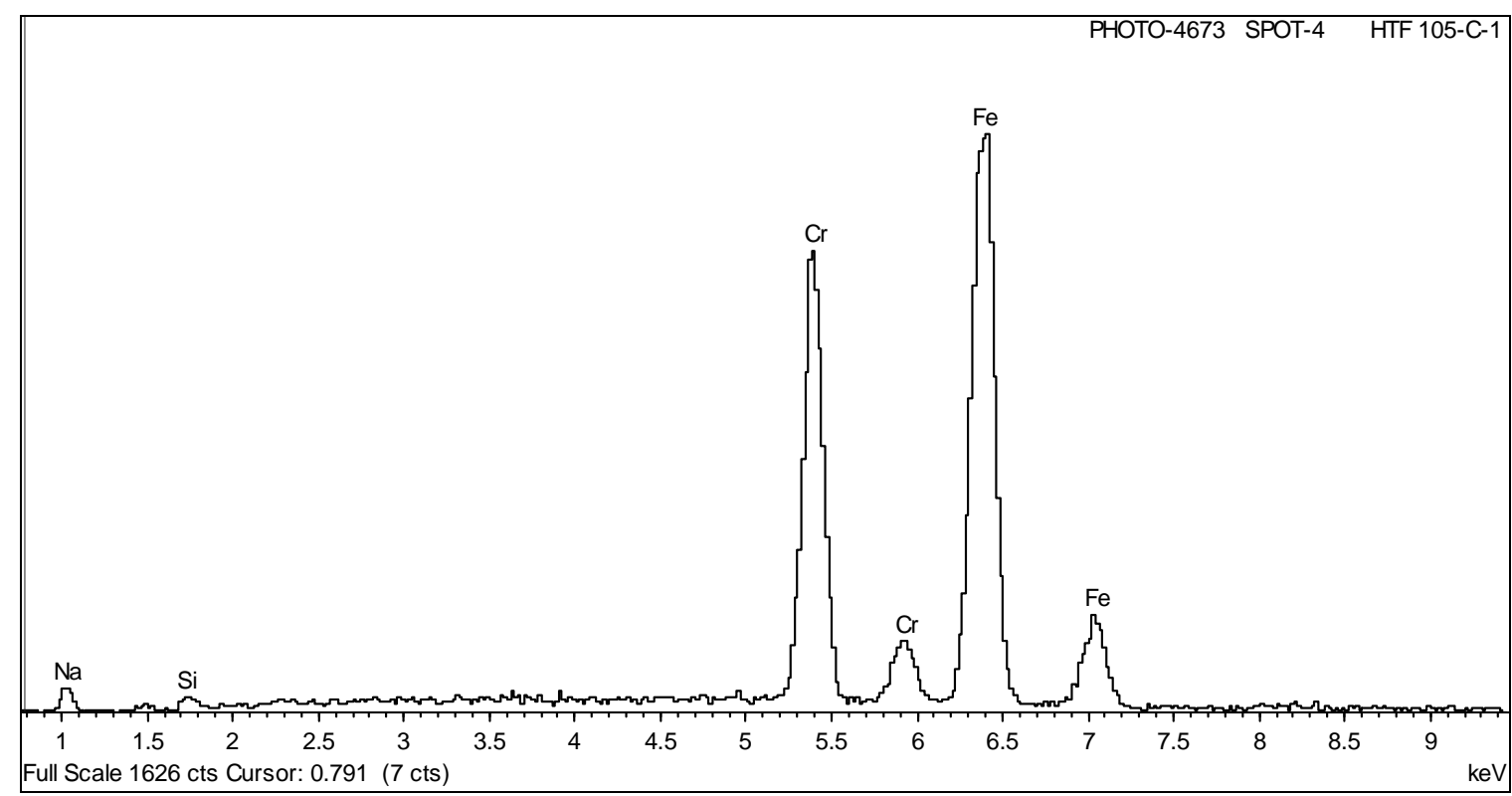

Figure 3.36 Spectrum of Spot 4 from Figure 3.32 


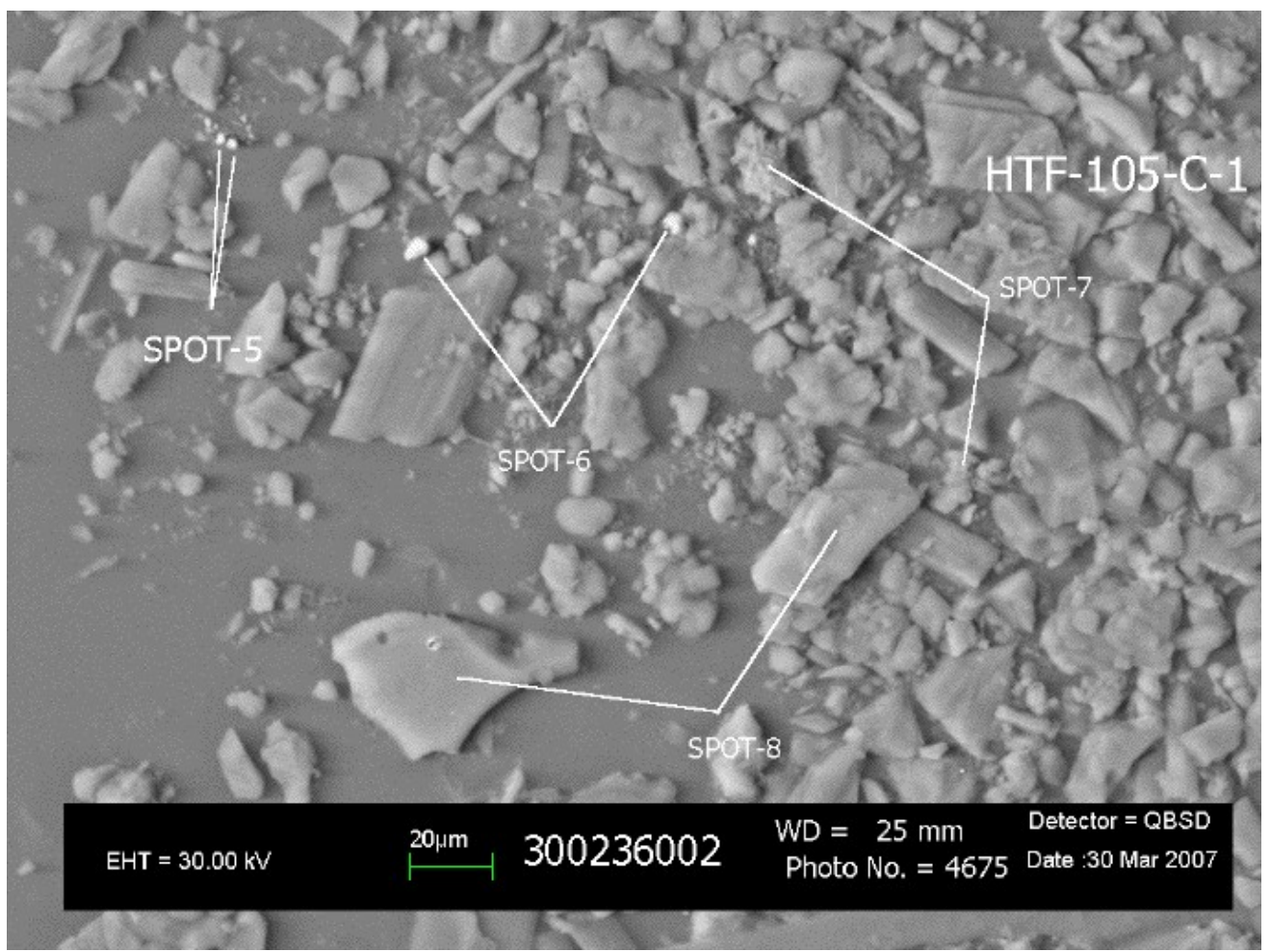

Figure 3.37 SEM Micrograph of Solids from Tank 16H Sample HTF-16-06-105C-1 (375X Magnification)

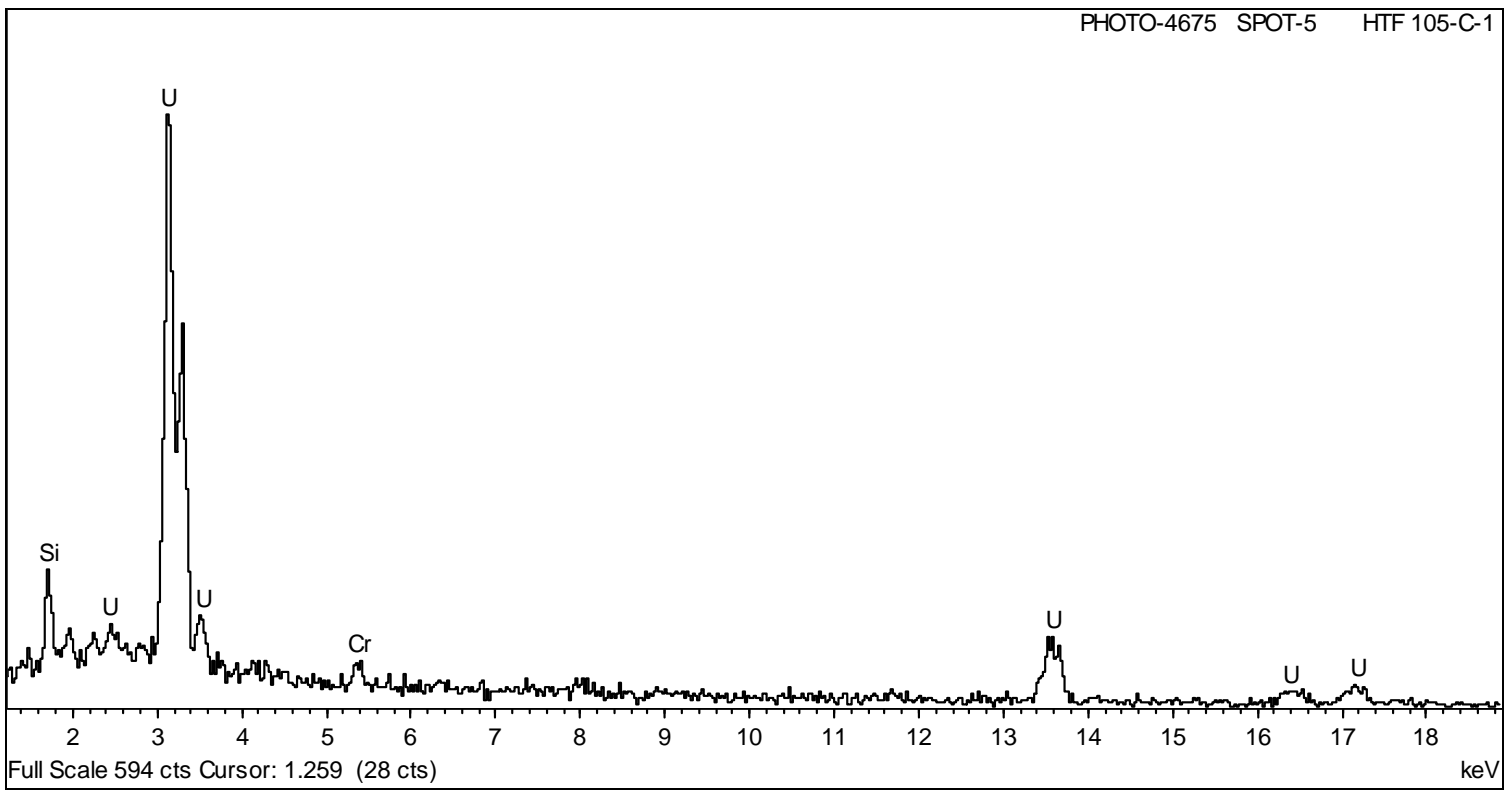

Figure 3.38 Spectrum of Spot 5 from Figure 3.37 
WSRC-STI-2008-00203, REV. 0

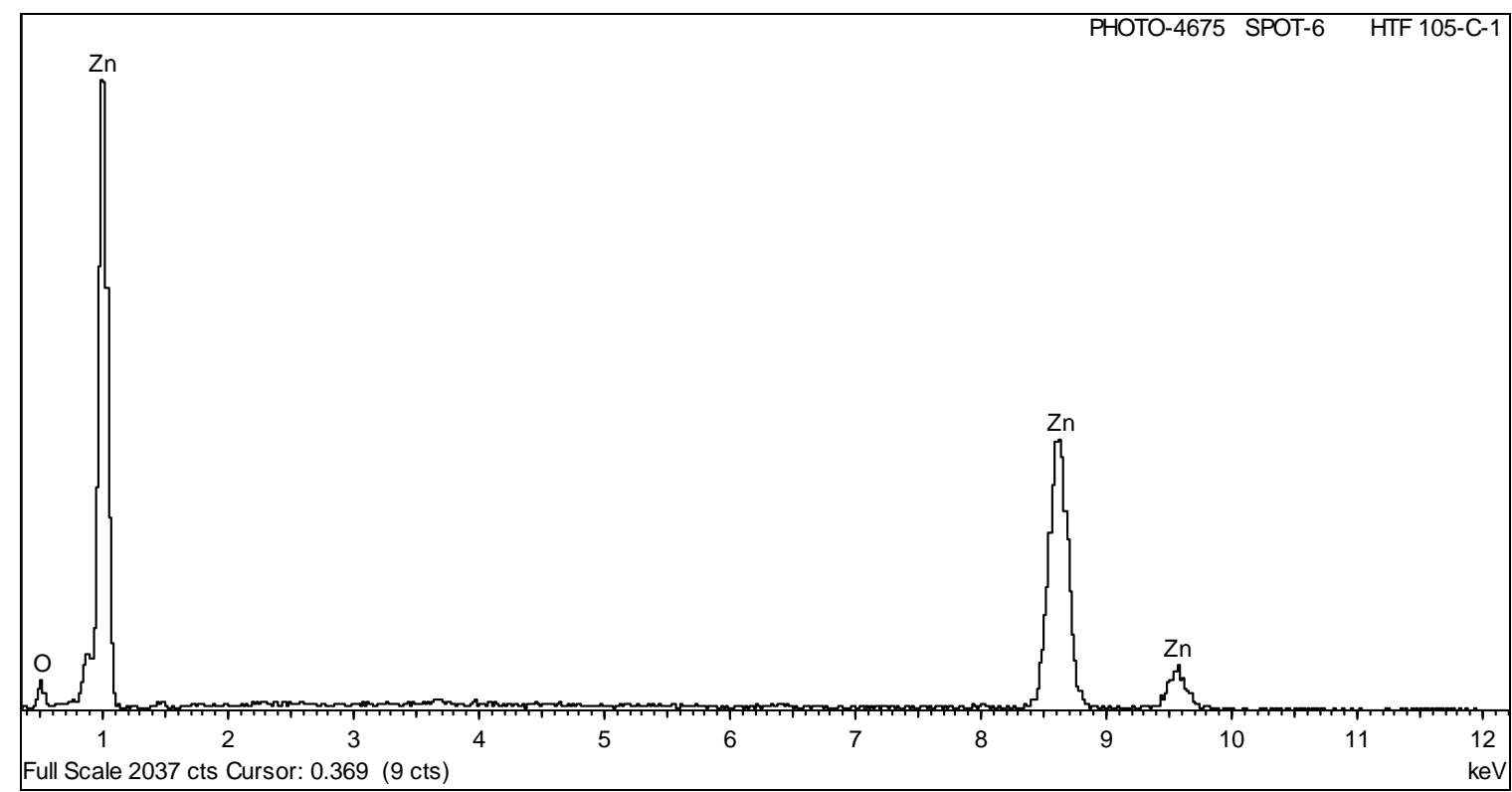

Figure 3.39 Spectrum of Spot 6 from Figure 3.37

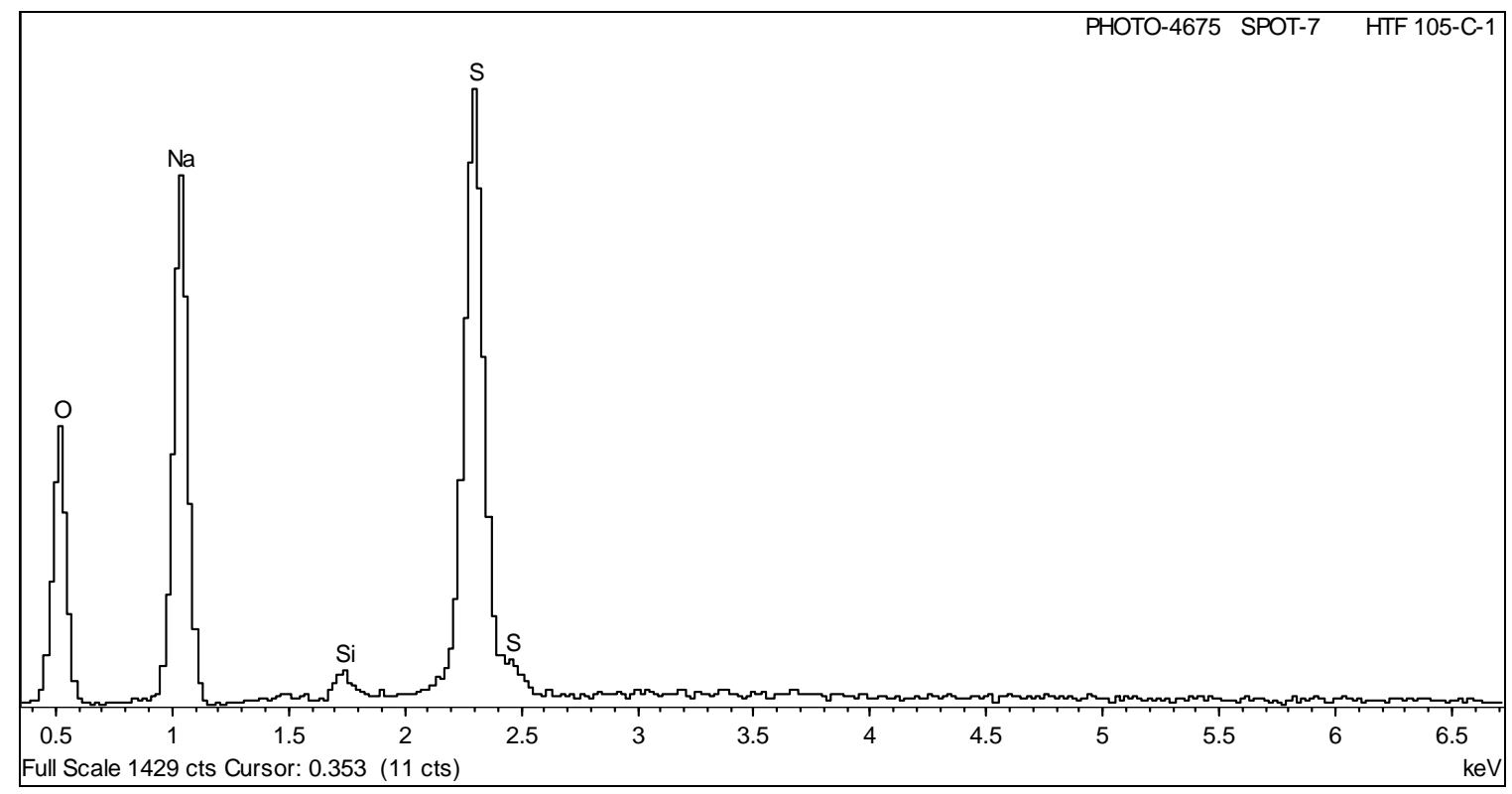

Figure 3.40 Spectrum of Spot 7 from Figure 3.37 
WSRC-STI-2008-00203, REV. 0

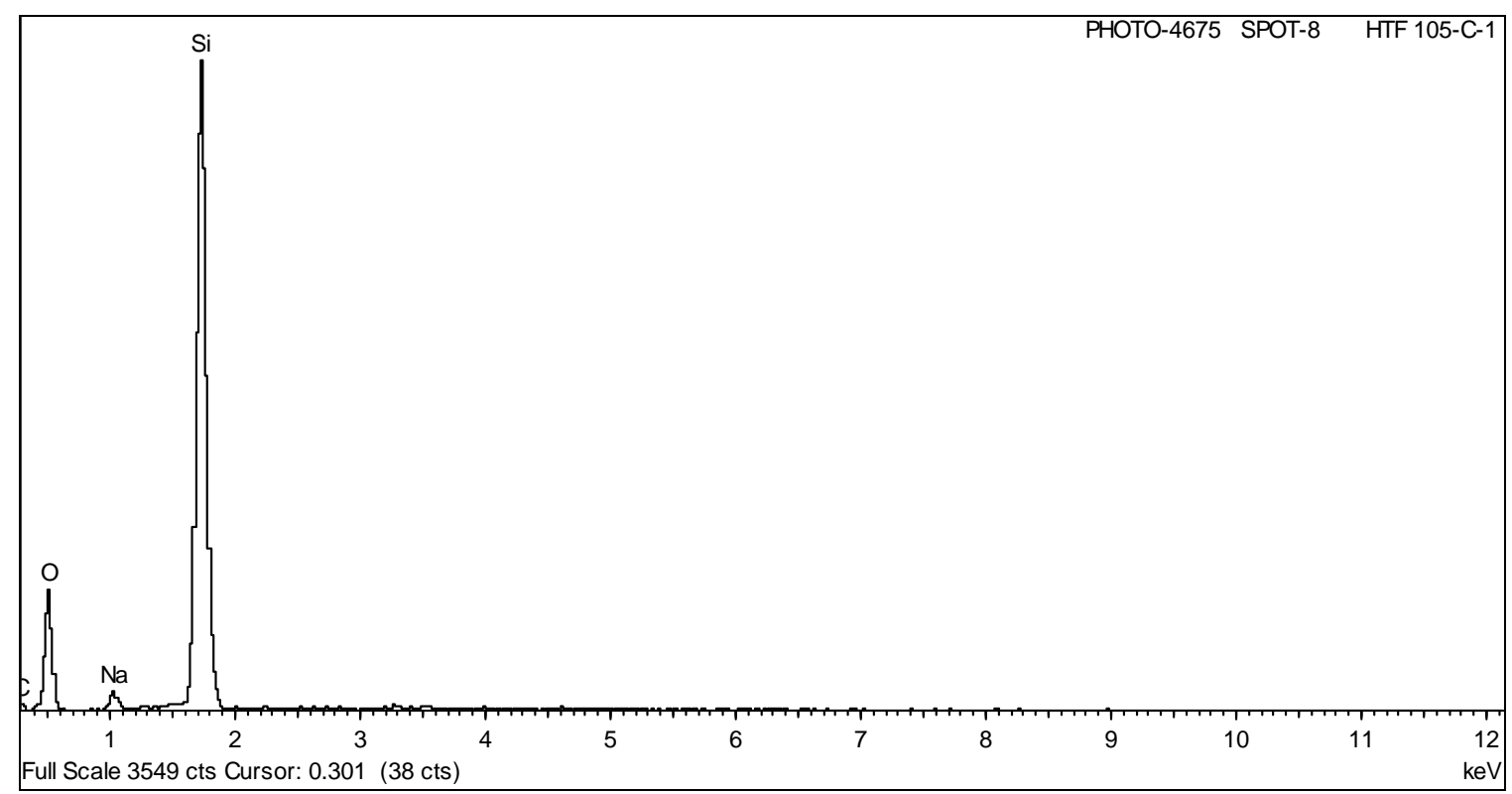

Figure 3.41 Spectrum of Spot 8 from Figure 3.37 


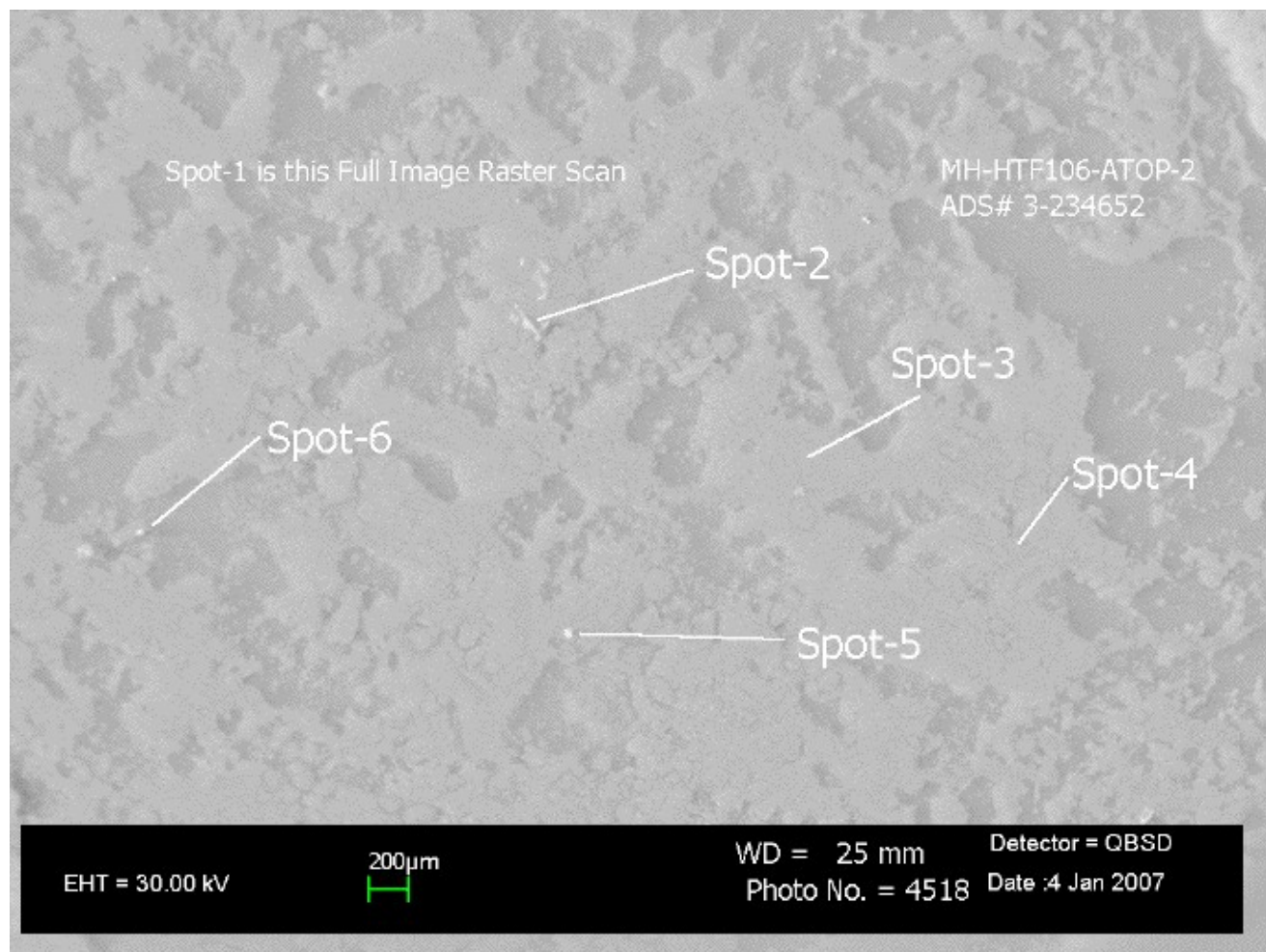

Figure 3.42 SEM Micrograph of Solids from Tank 16H Sample HTF-16-06-106ATOP-2 (18X Magnification)

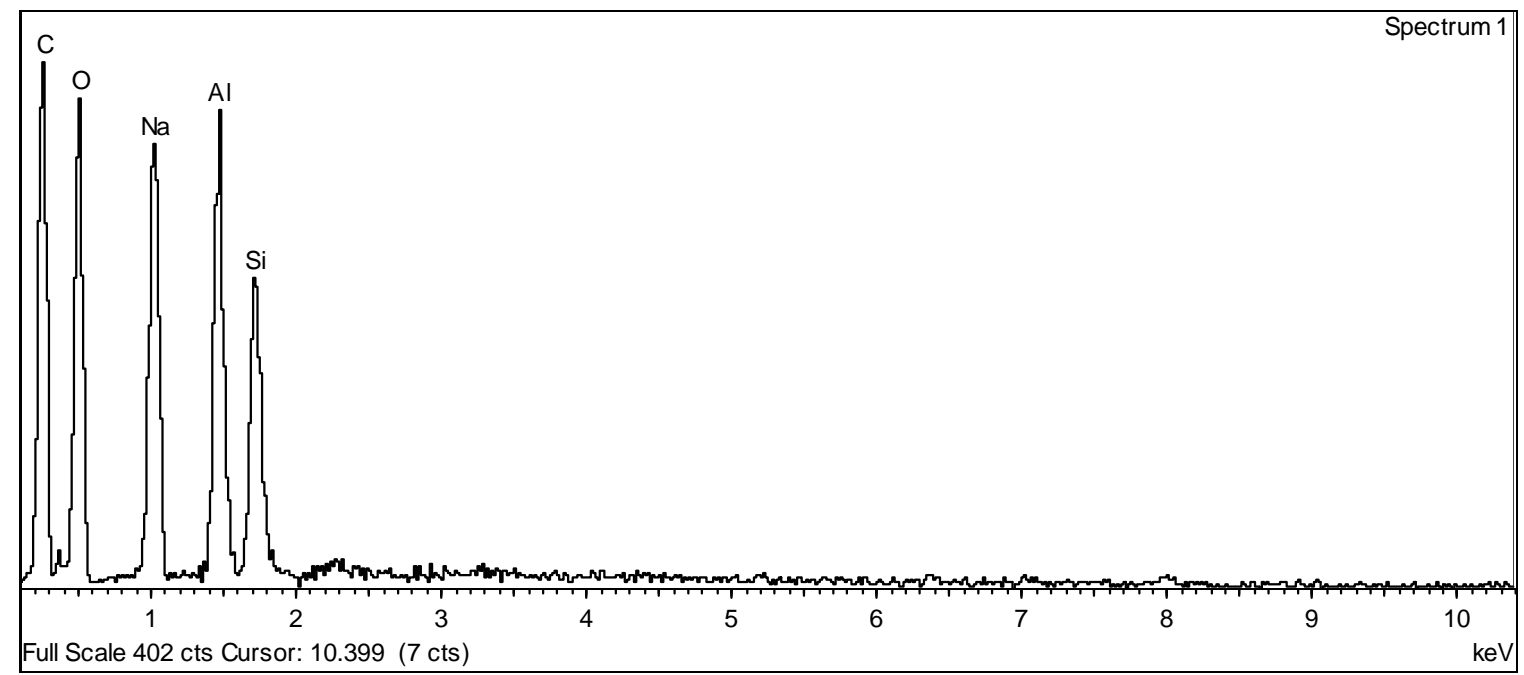

Figure 3.43 Spectrum of Spot 1 from Figure 3.42 
WSRC-STI-2008-00203, REV. 0

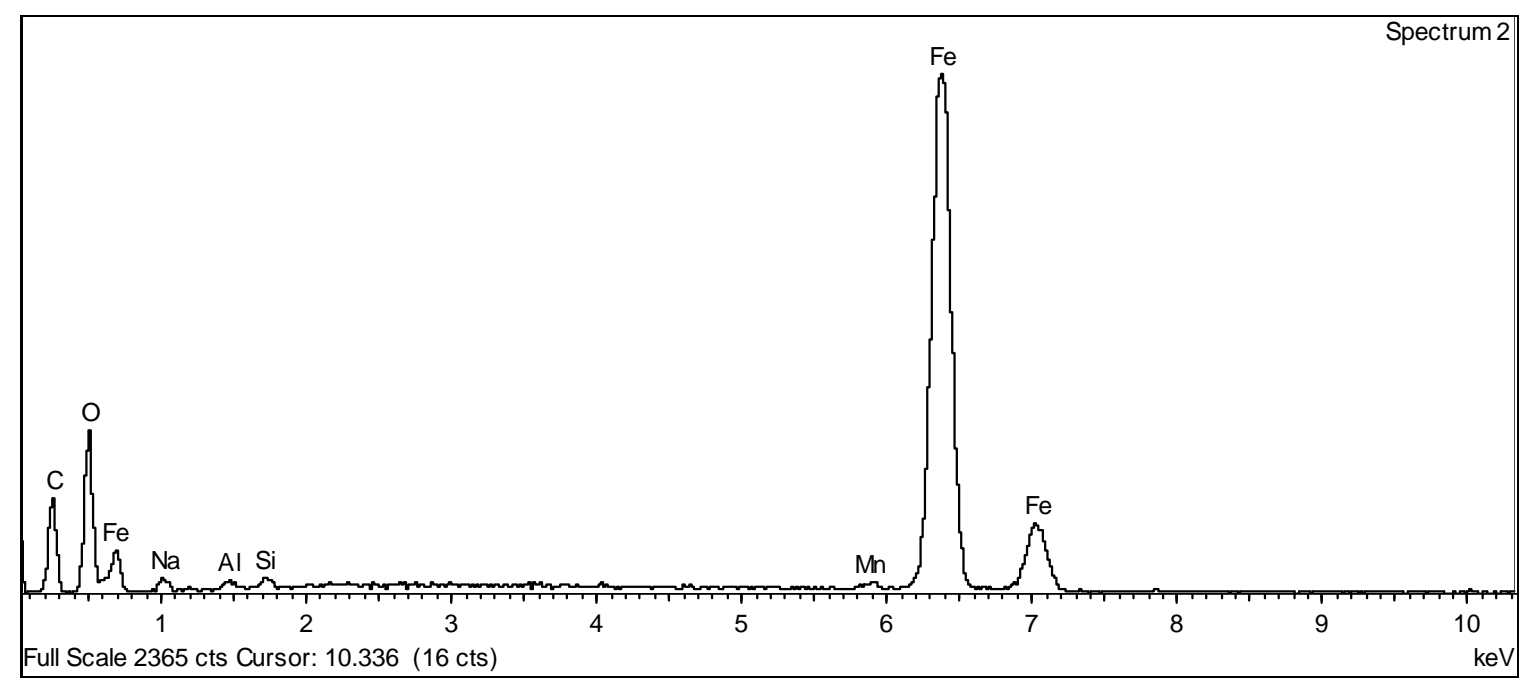

Figure 3.44 Spectrum of Spot 2 from Figure 3.42

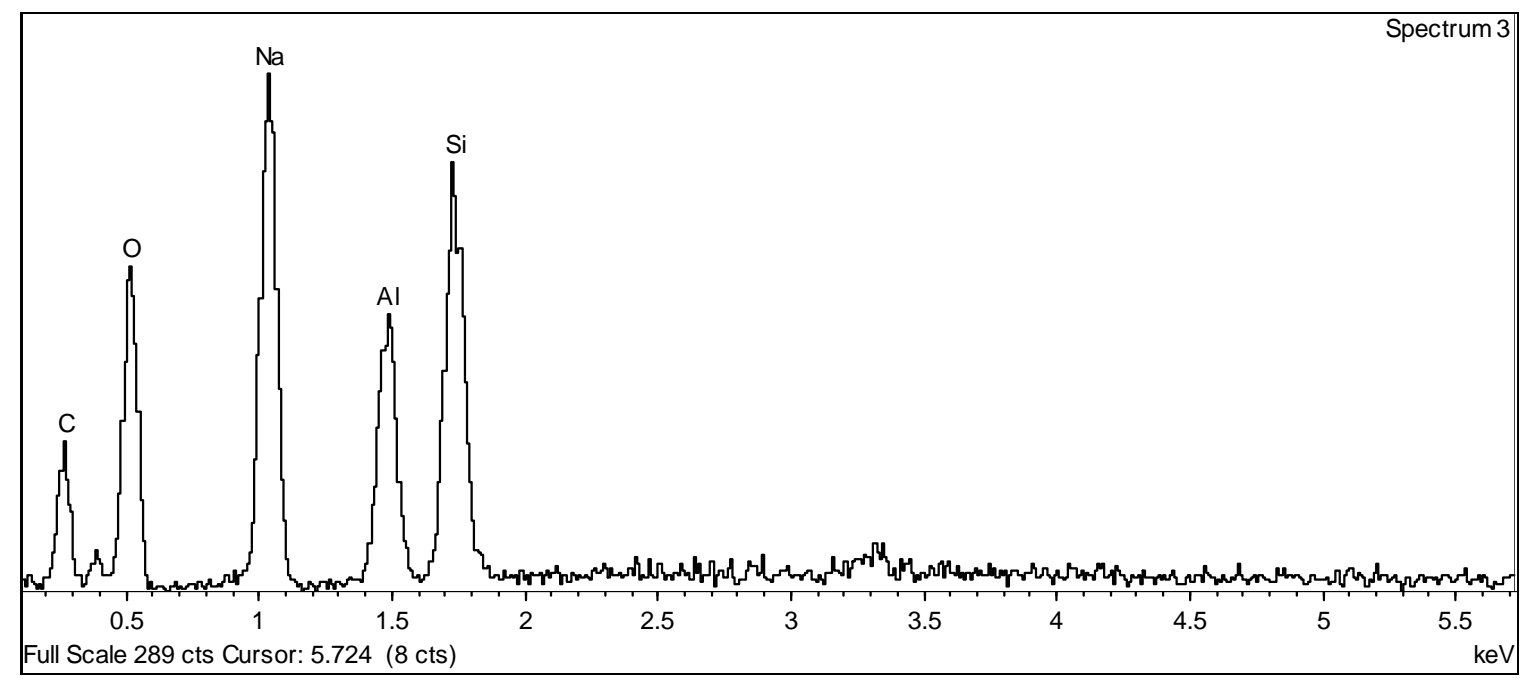

Figure 3.45 Spectrum of Spot 3 from Figure 3.42 
WSRC-STI-2008-00203, REV. 0

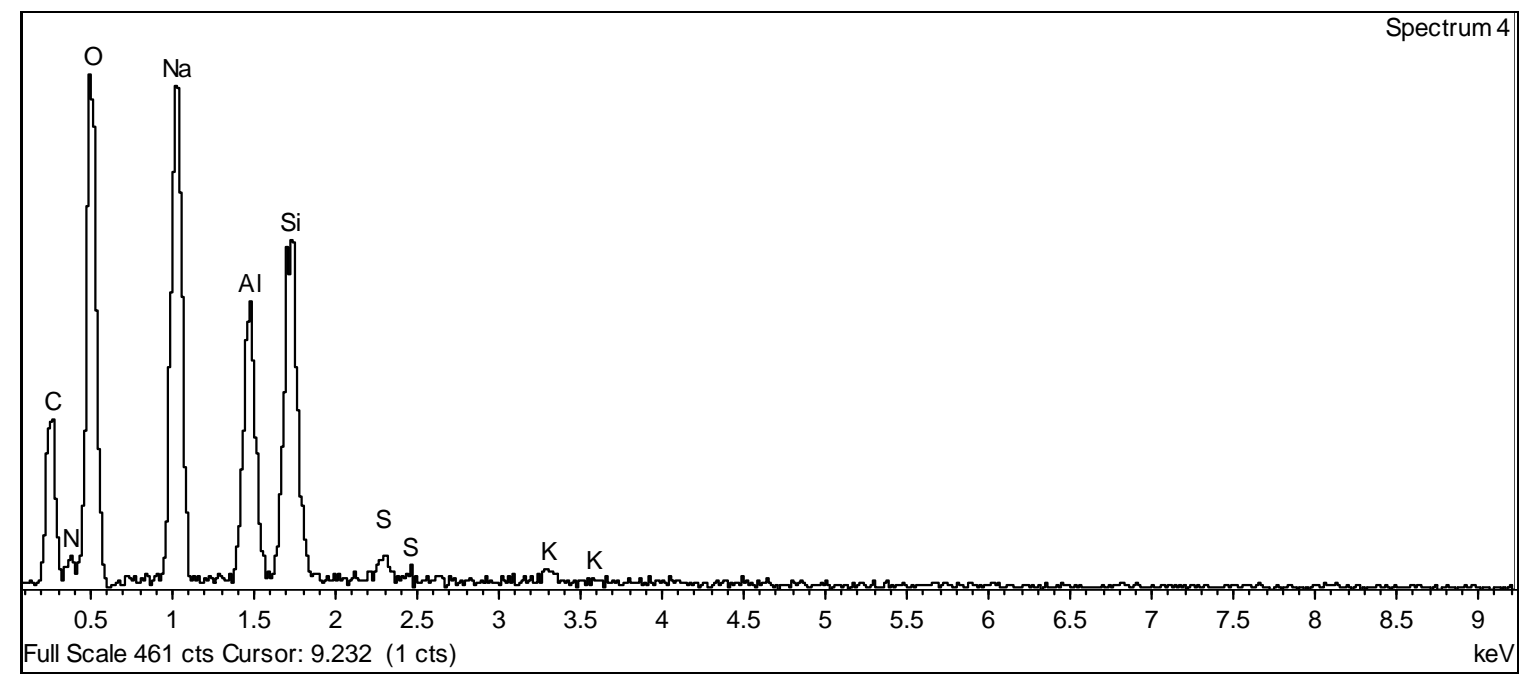

Figure 3.46 Spectrum of Spot 4 from Figure 3.42

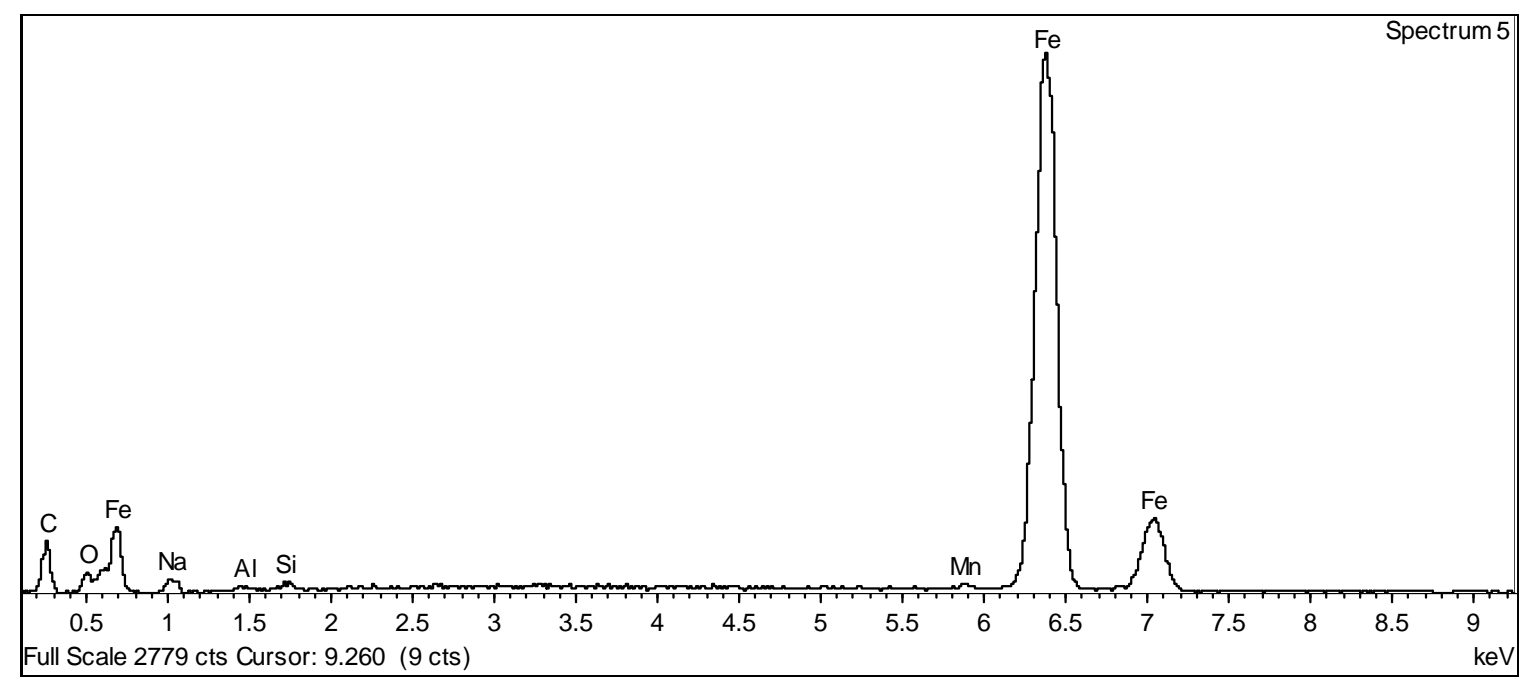

Figure 3.47 Spectrum of Spot 5 from Figure 3.42 
WSRC-STI-2008-00203, REV. 0

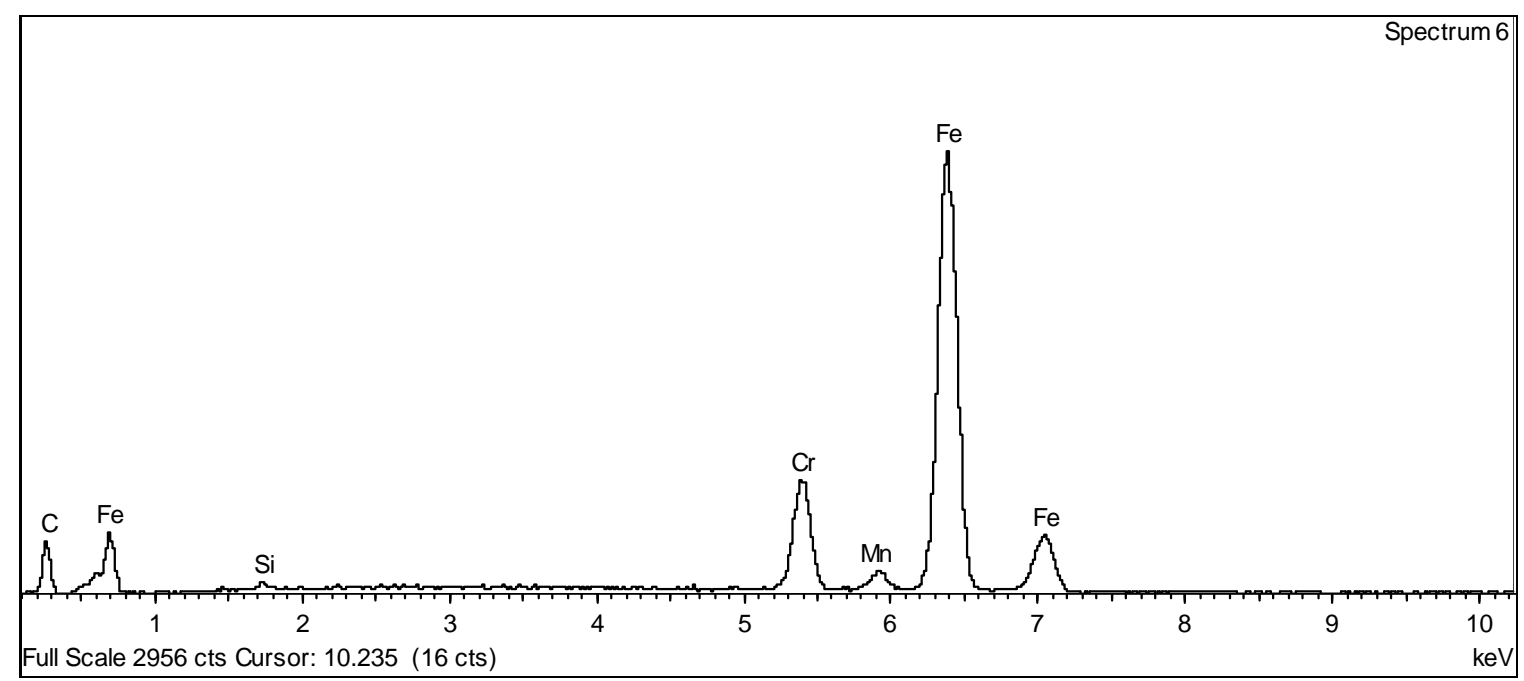

Figure 3.48 Spectrum of Spot 6 from Figure 3.42 


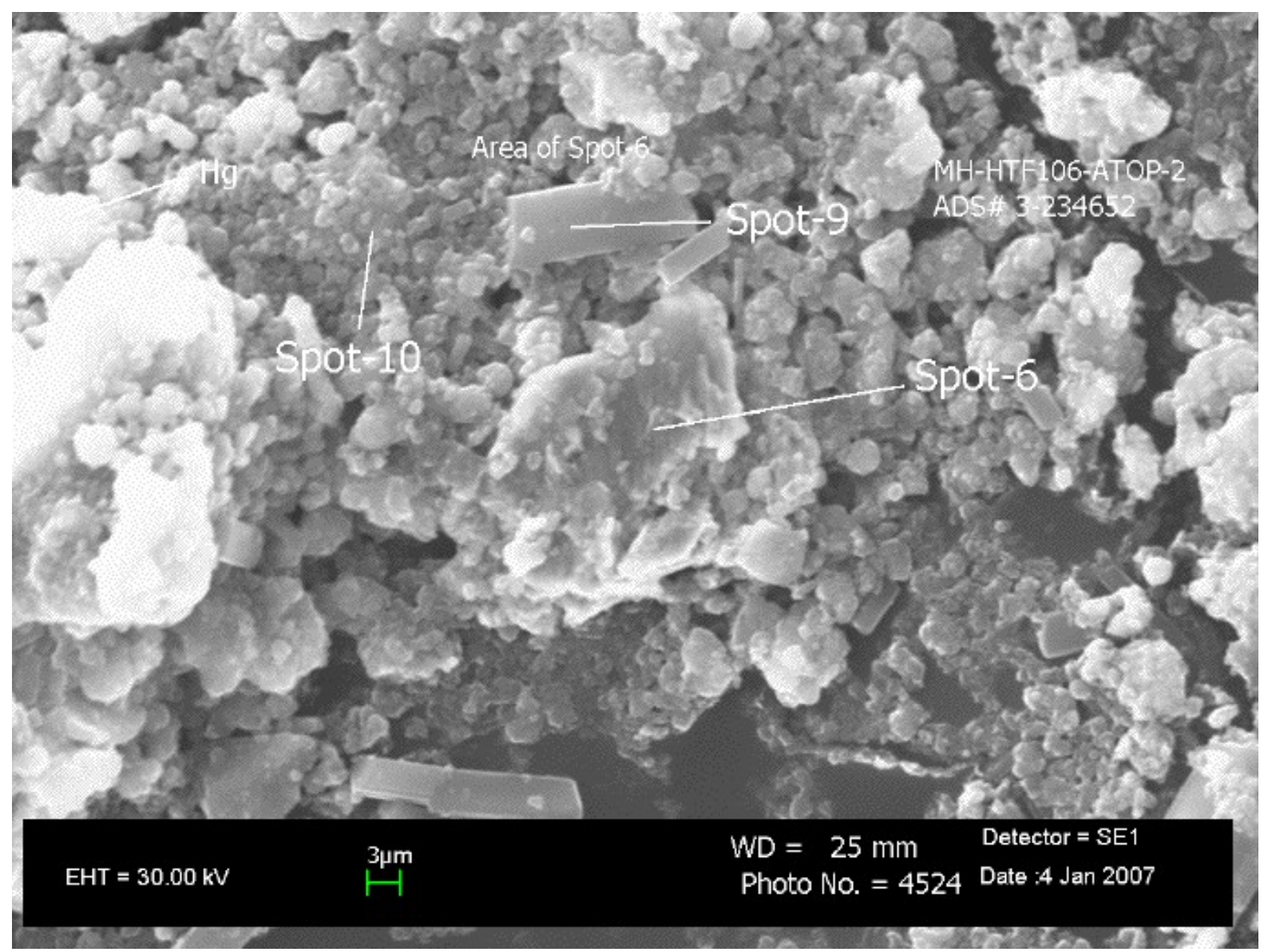

Figure 3.49 SEM Micrograph of Solids from Tank 16H Sample HTF-16-06-106ATOP-2 (1000X Magnification)

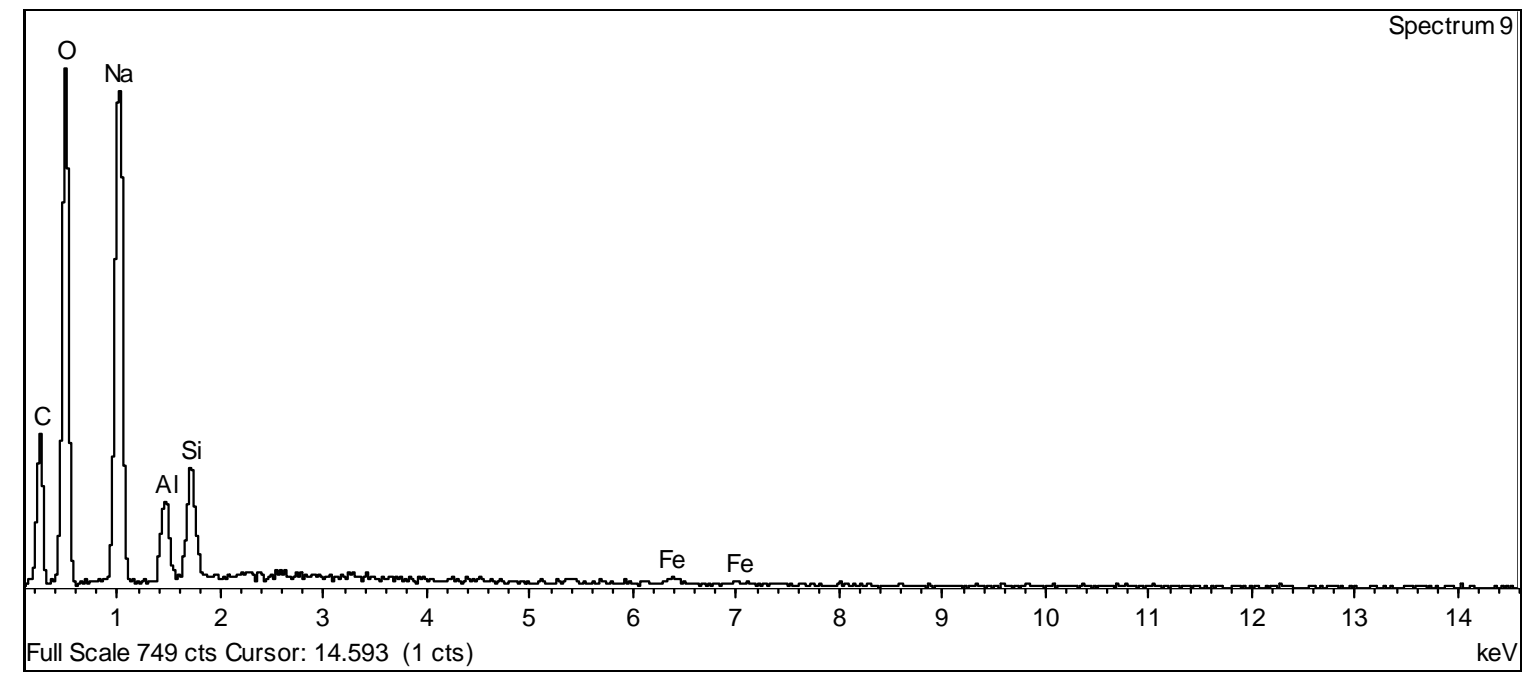

Figure 3.50 Spectrum of Spot 9 from Figure 3.49 
WSRC-STI-2008-00203, REV. 0

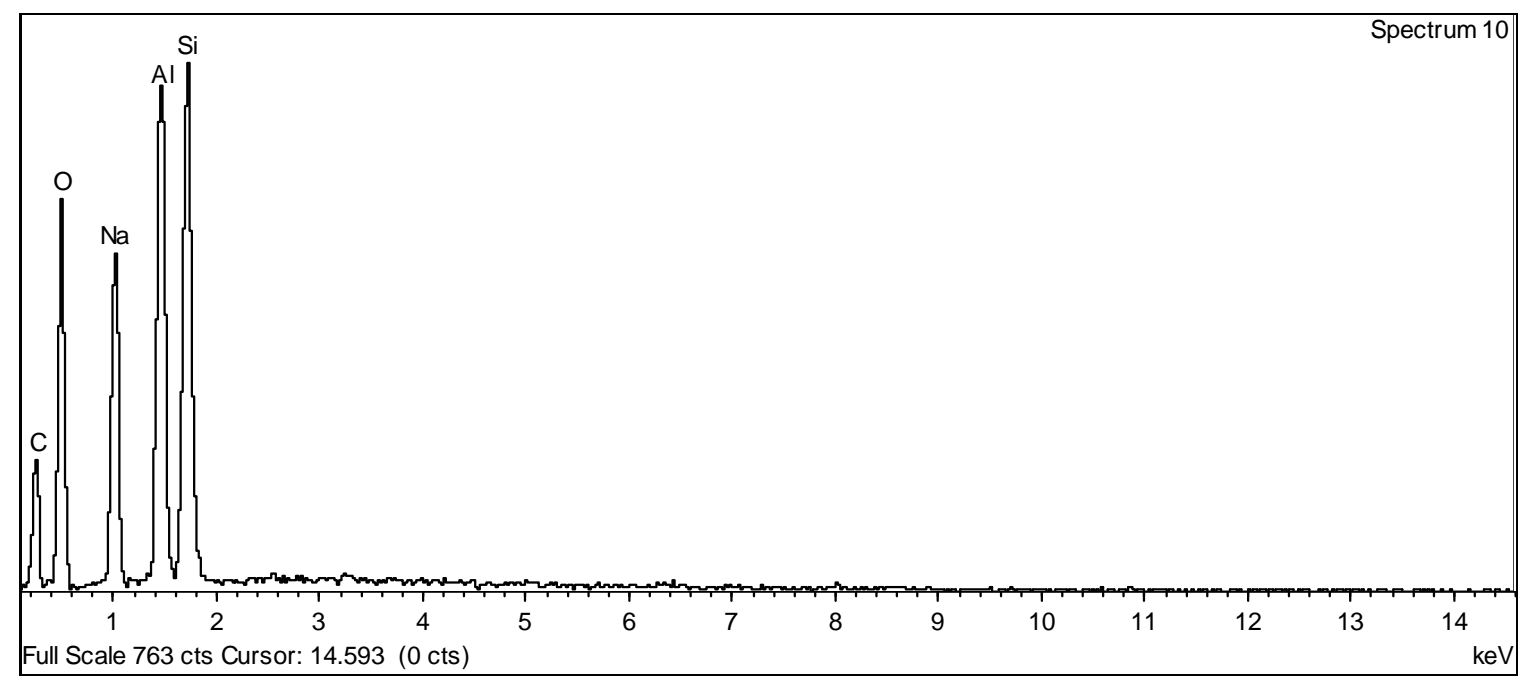

Figure 3.51 Spectrum of Spot 10 from Figure 3.49 


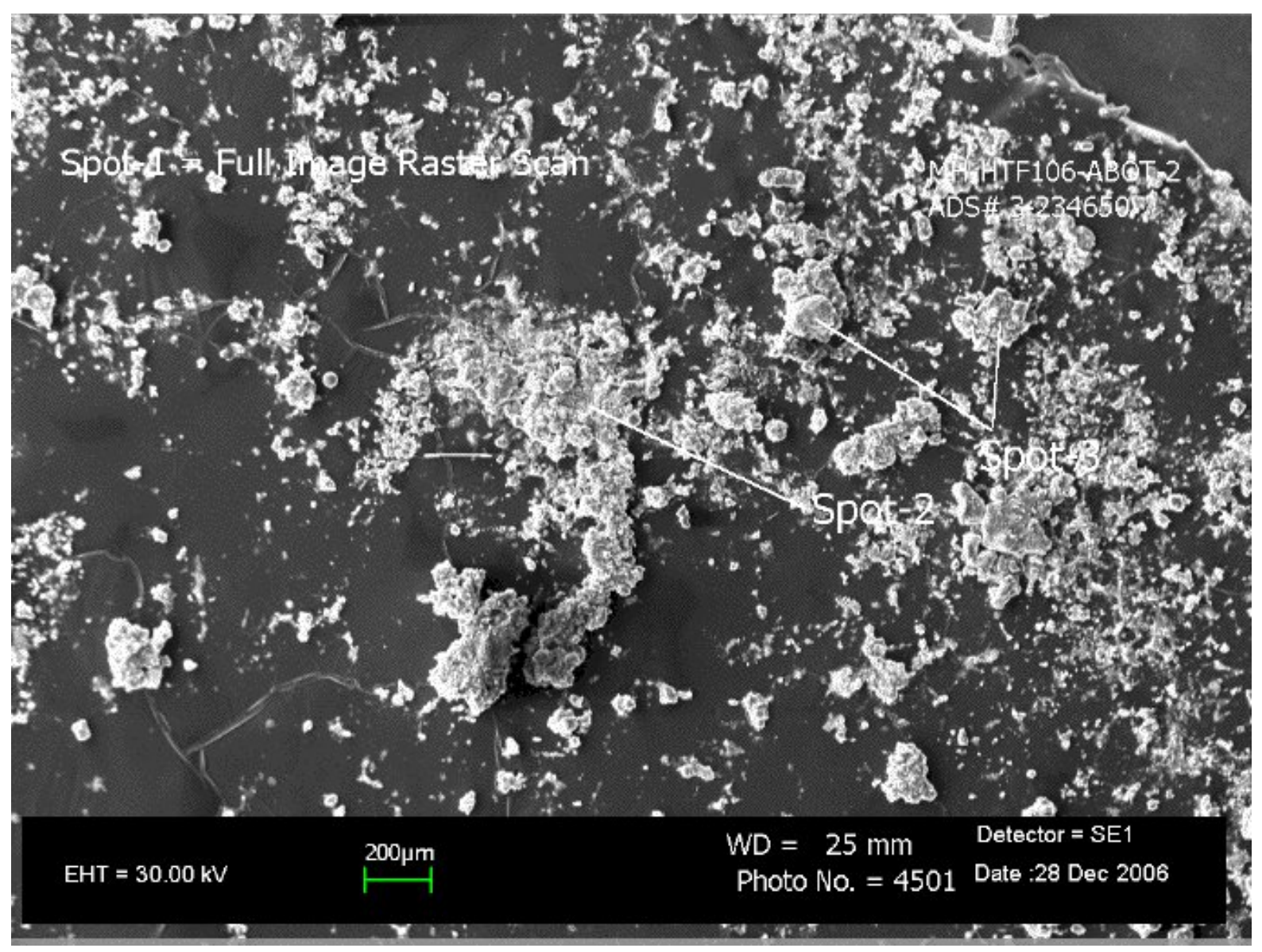

Figure 3.52 SEM Micrograph of Solids from Tank 16H Sample HTF-16-06-106ABOT-2 (30X Magnification)

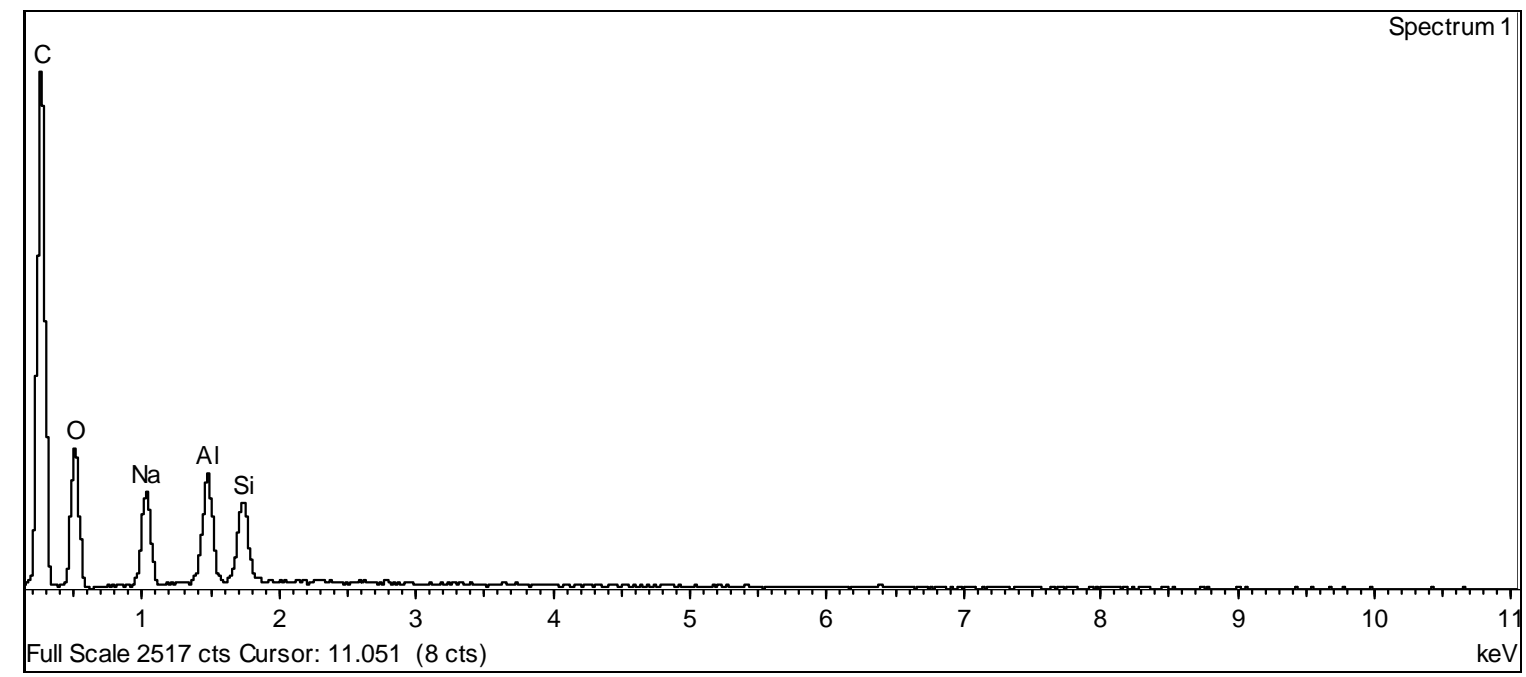

Figure 3.53 Spectrum of Raster Scan from Figure 3.52 
WSRC-STI-2008-00203, REV. 0

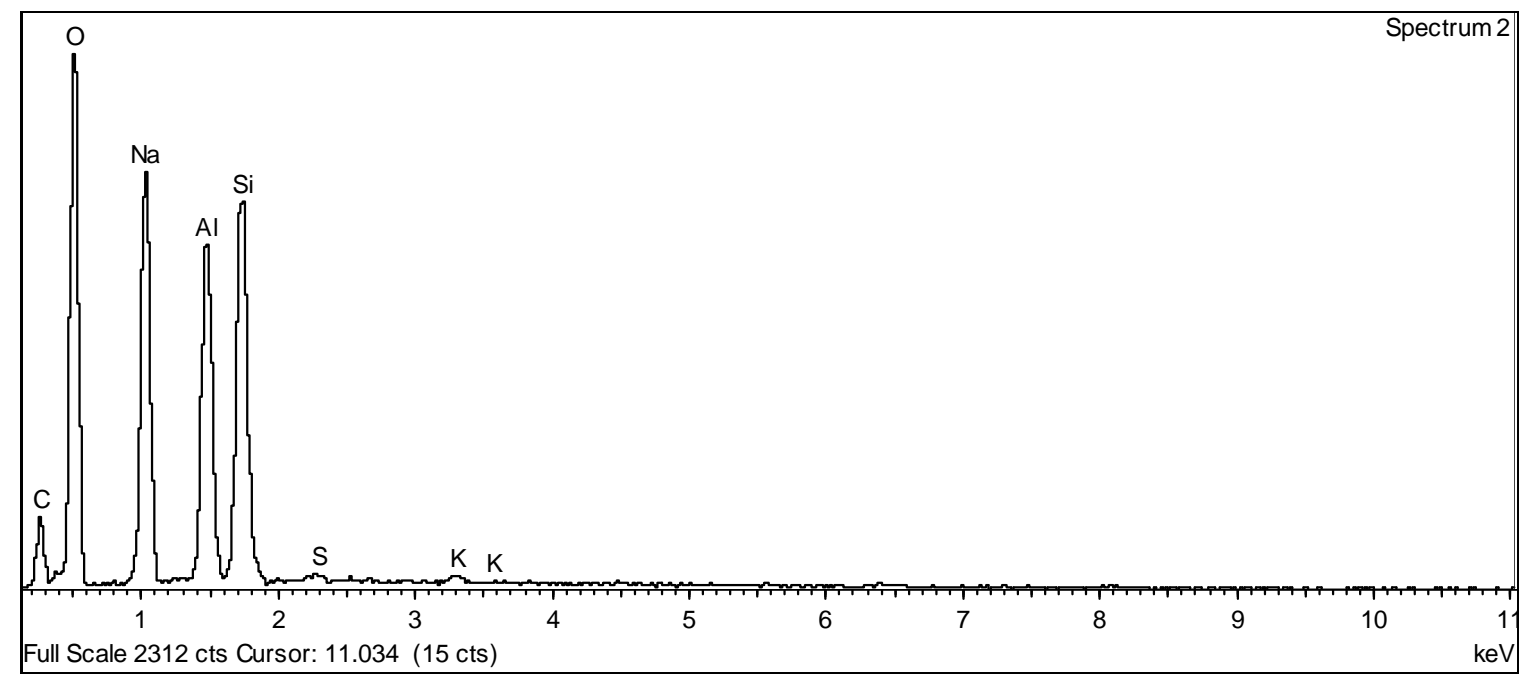

Figure 3.54 Spectrum of Spot 2 from Figure 3.52

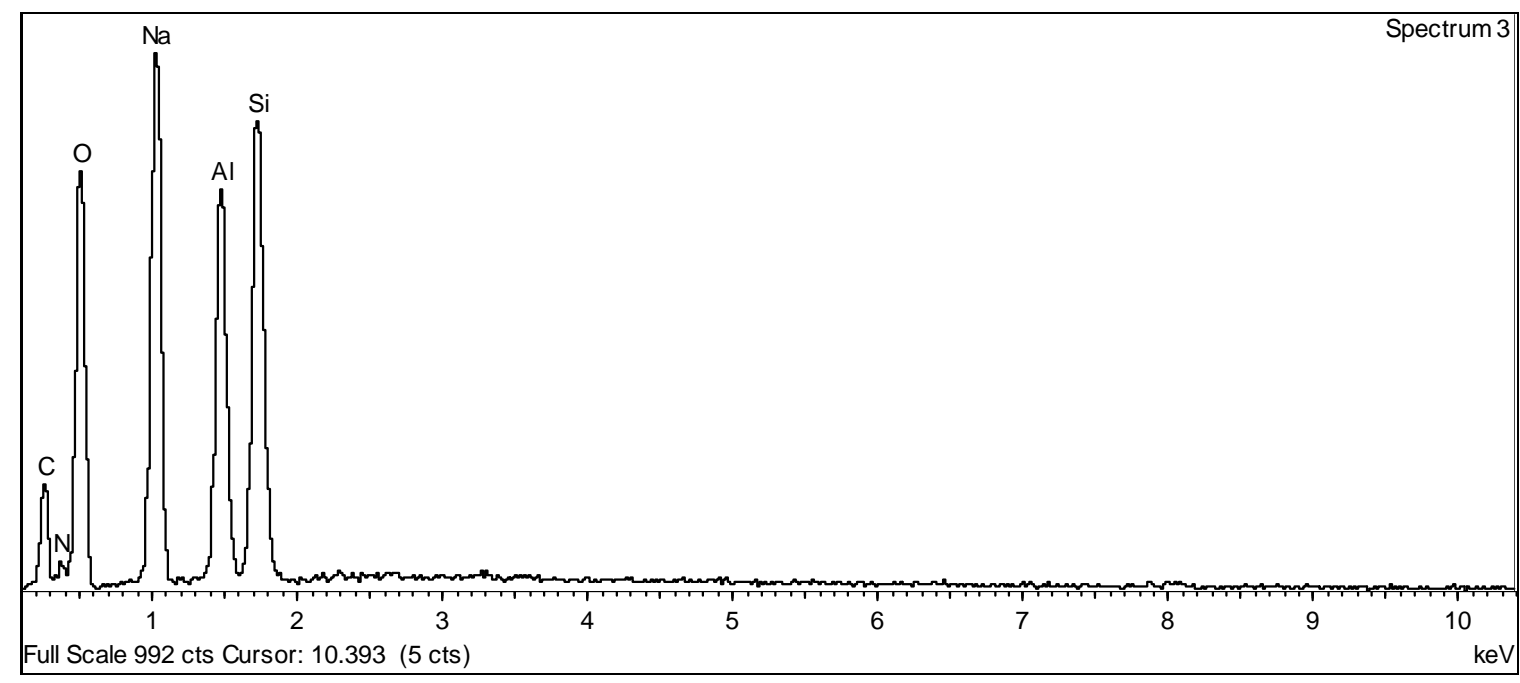

Figure 3.55 Spectrum of Spot 3 from Figure 3.52 


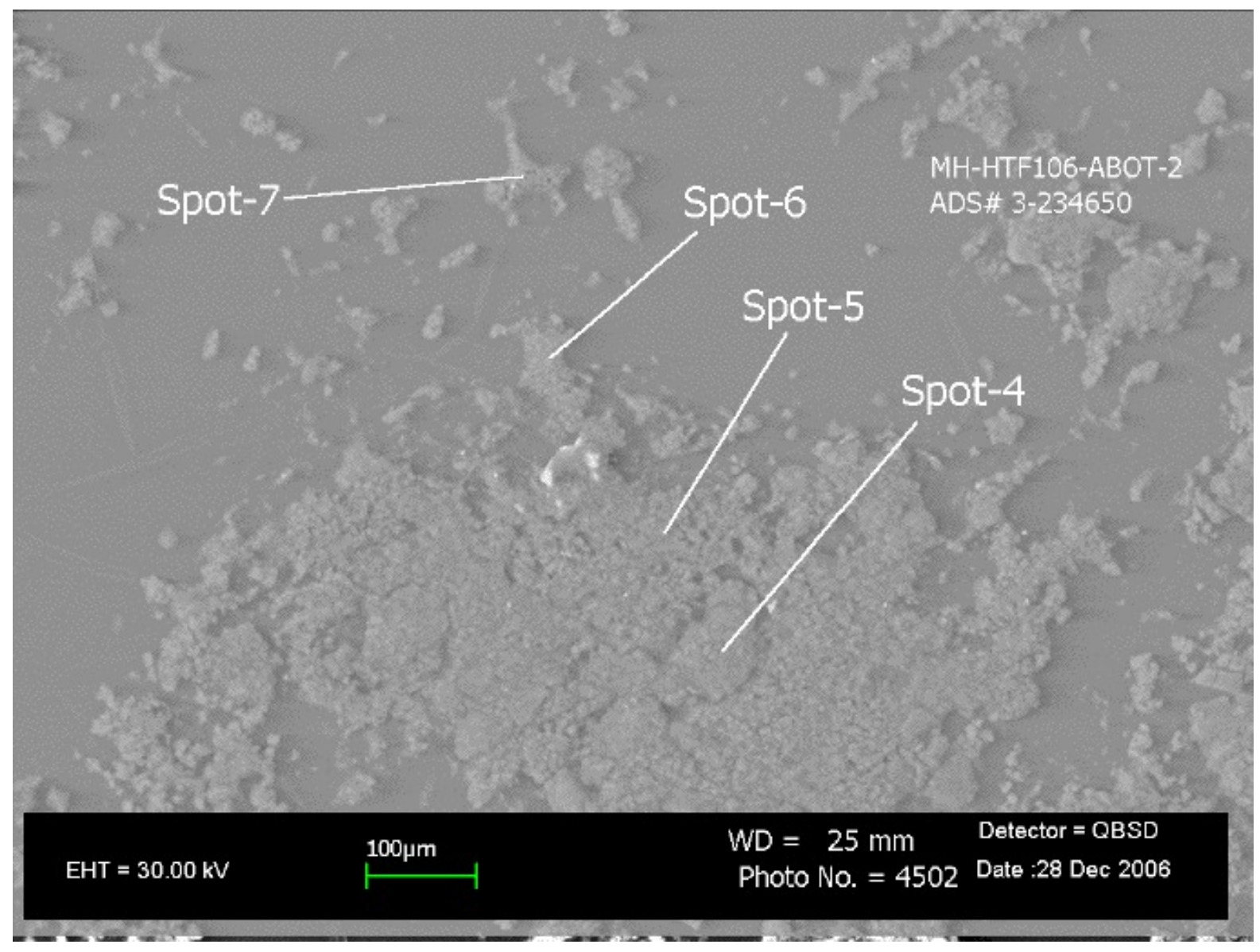

Figure 3.56 SEM Micrograph of Solids from Tank 16H Sample HTF-16-06-106ABOT-2 (100X Magnification)

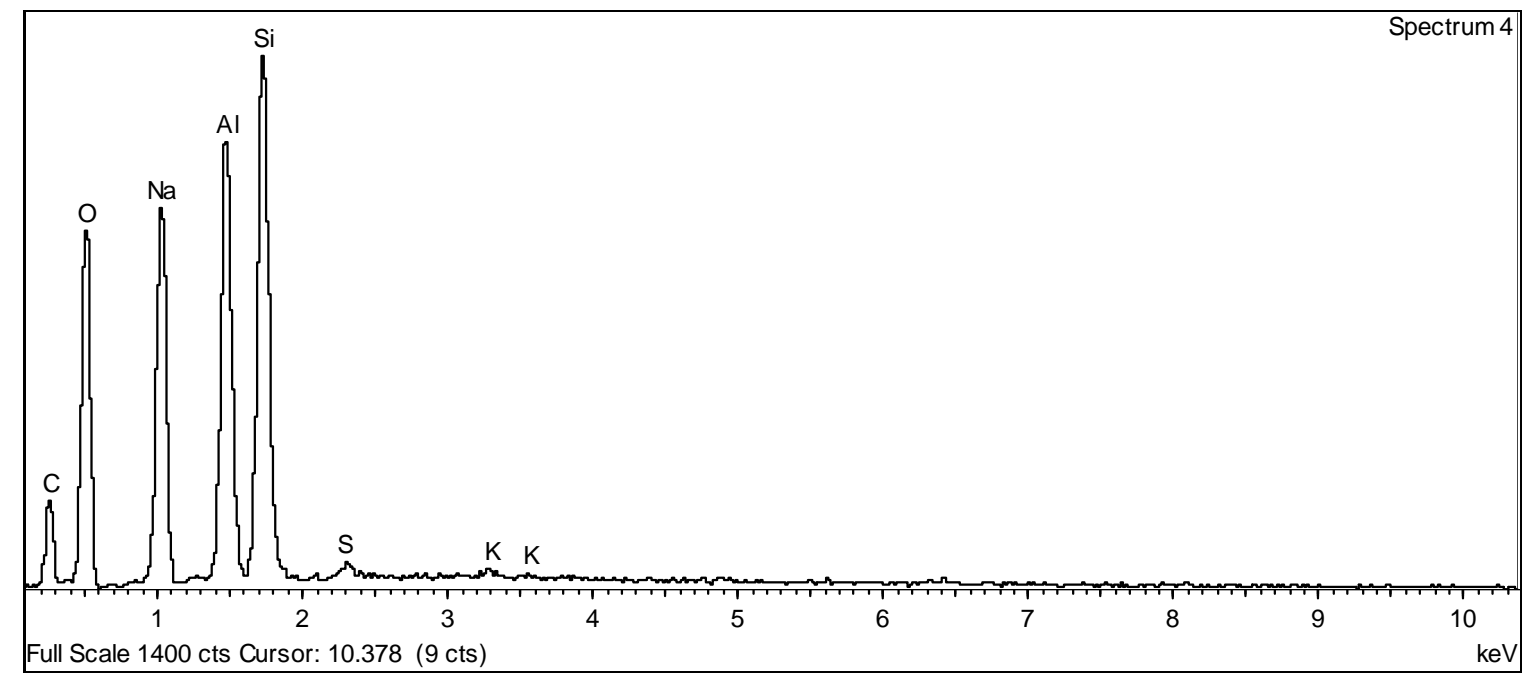

Figure 3.57 Spectrum of Spot 4 from Figure 3.56 
WSRC-STI-2008-00203, REV. 0

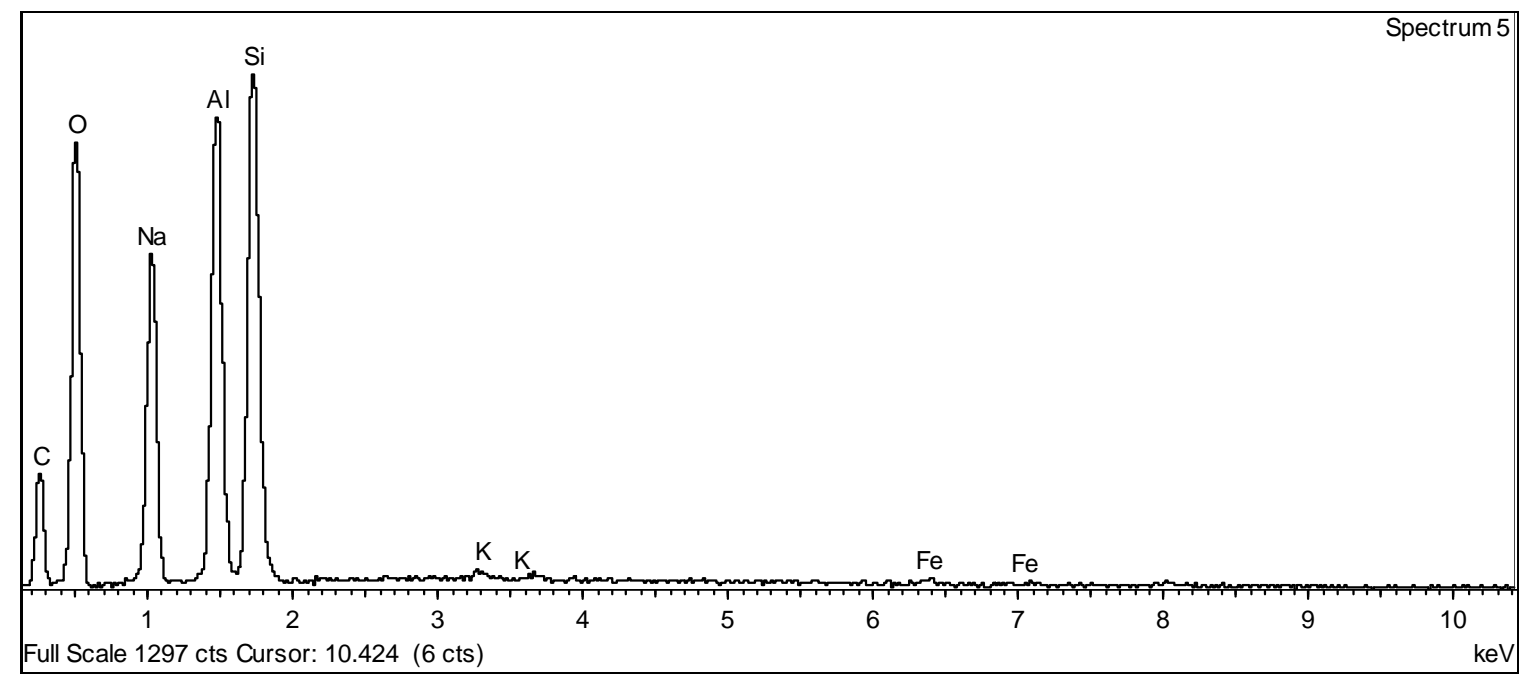

Figure 3.58 Spectrum of Spot 5 from Figure 3.56

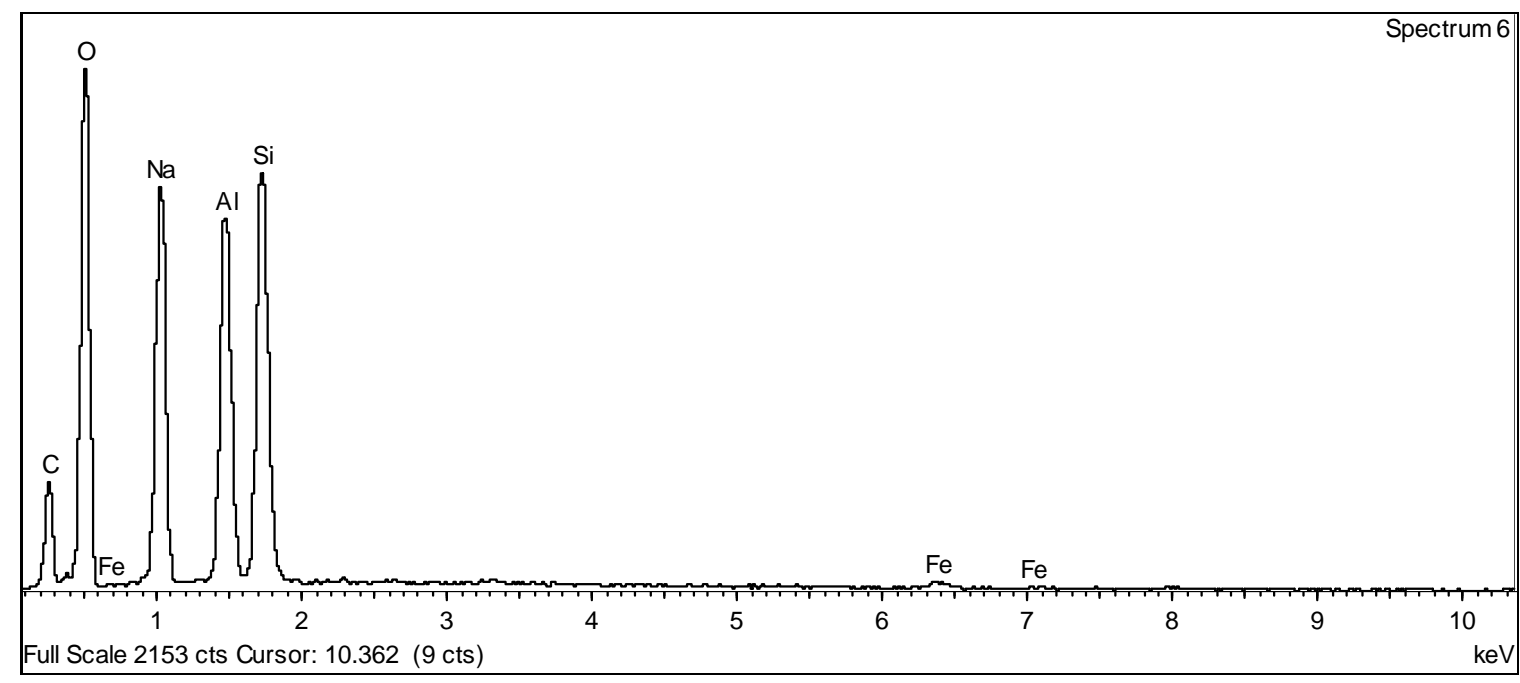

Figure 3.59 Spectrum of Spot 6 from Figure 3.56 
WSRC-STI-2008-00203, REV. 0

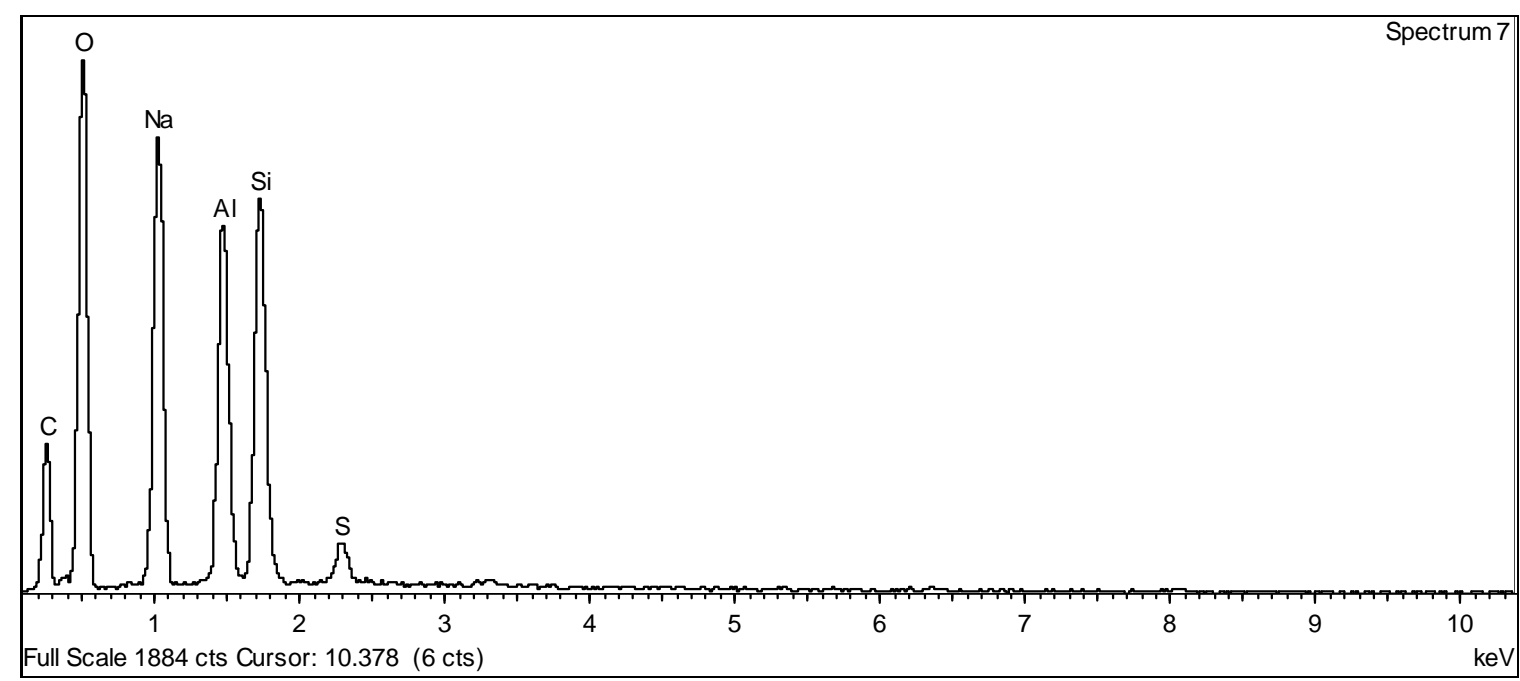

Figure 3.60 Spectrum of Spot 7 from Figure 3.56 


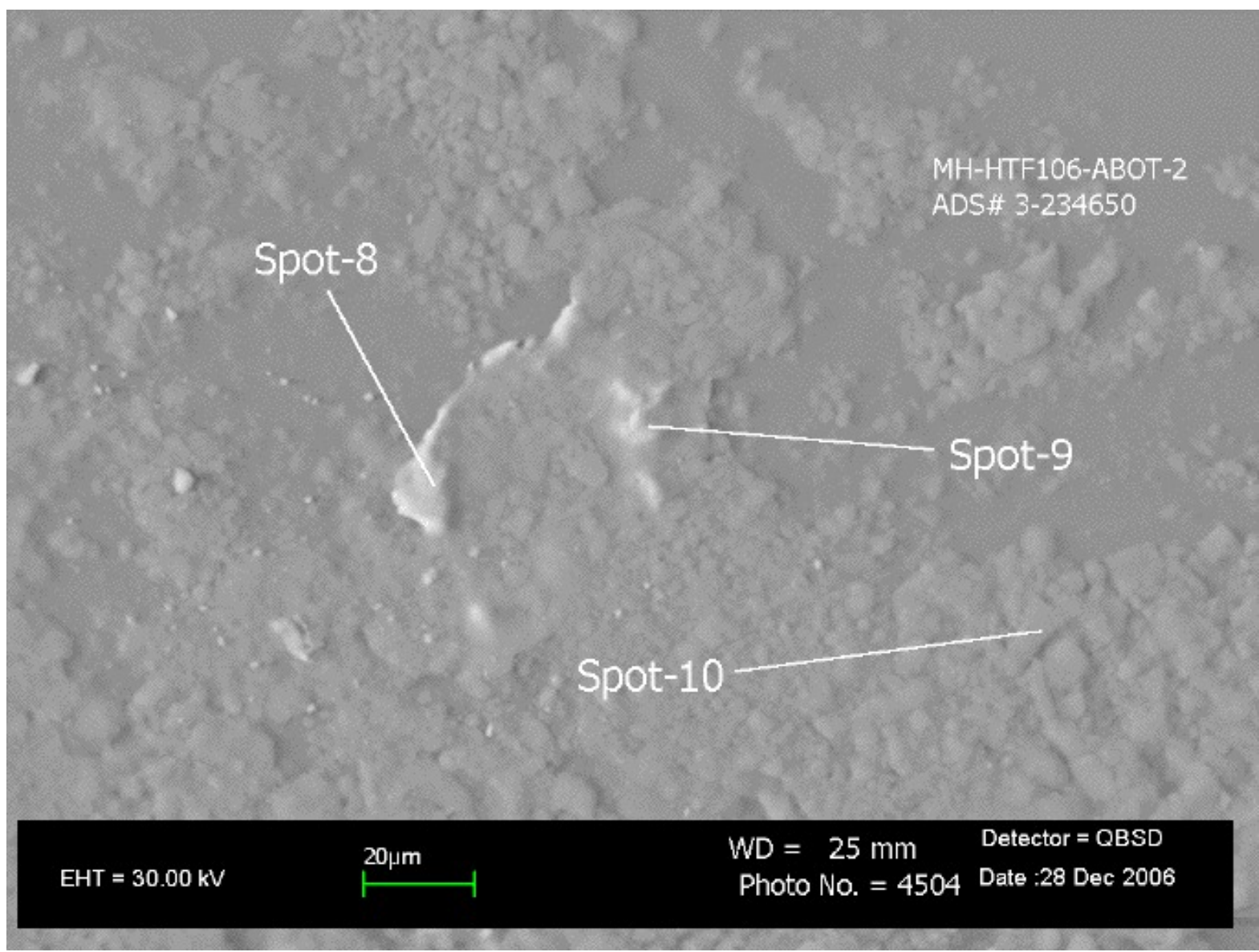

Figure 3.61 SEM Micrograph of Solids from Tank 16H Sample HTF-16-06-106ABOT-2 (500X Magnification)

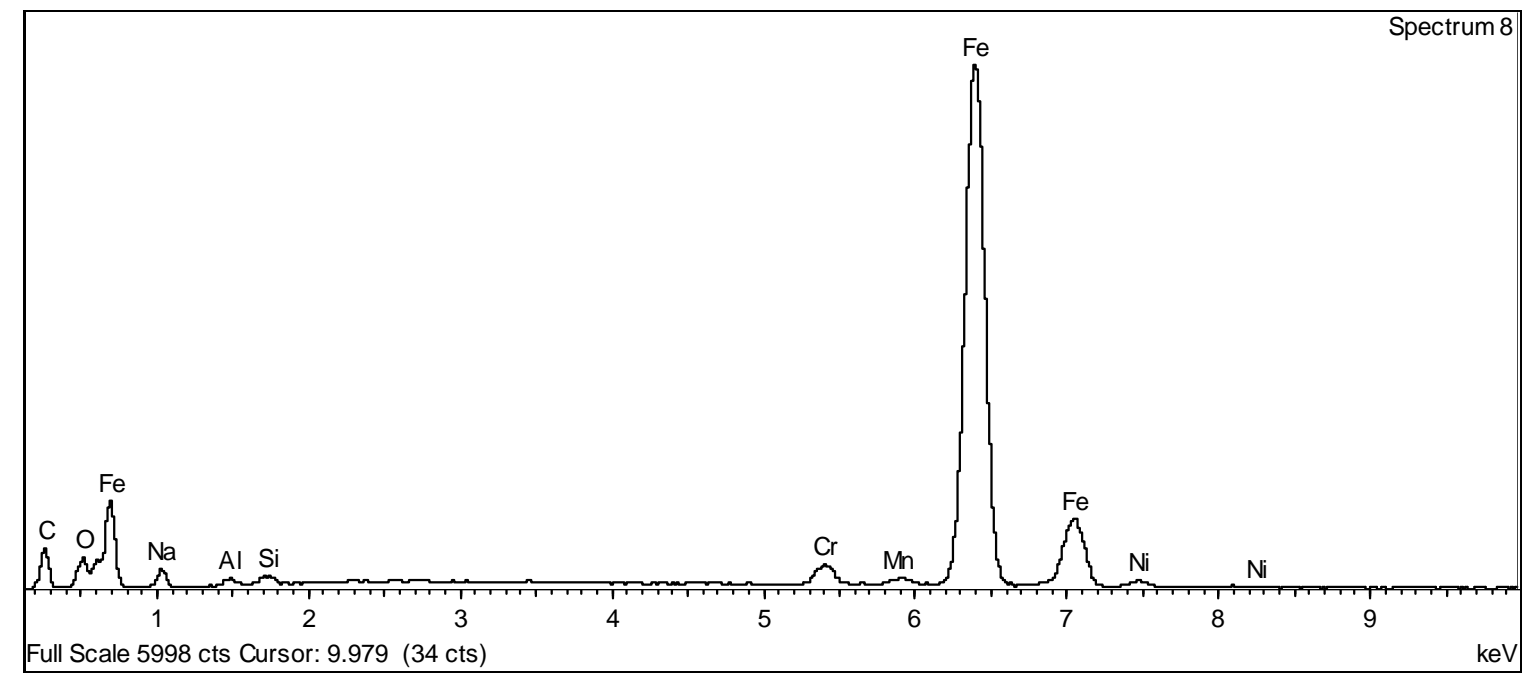

Figure 3.62 Spectrum of Spot 8 from Figure 3.61 
WSRC-STI-2008-00203, REV. 0

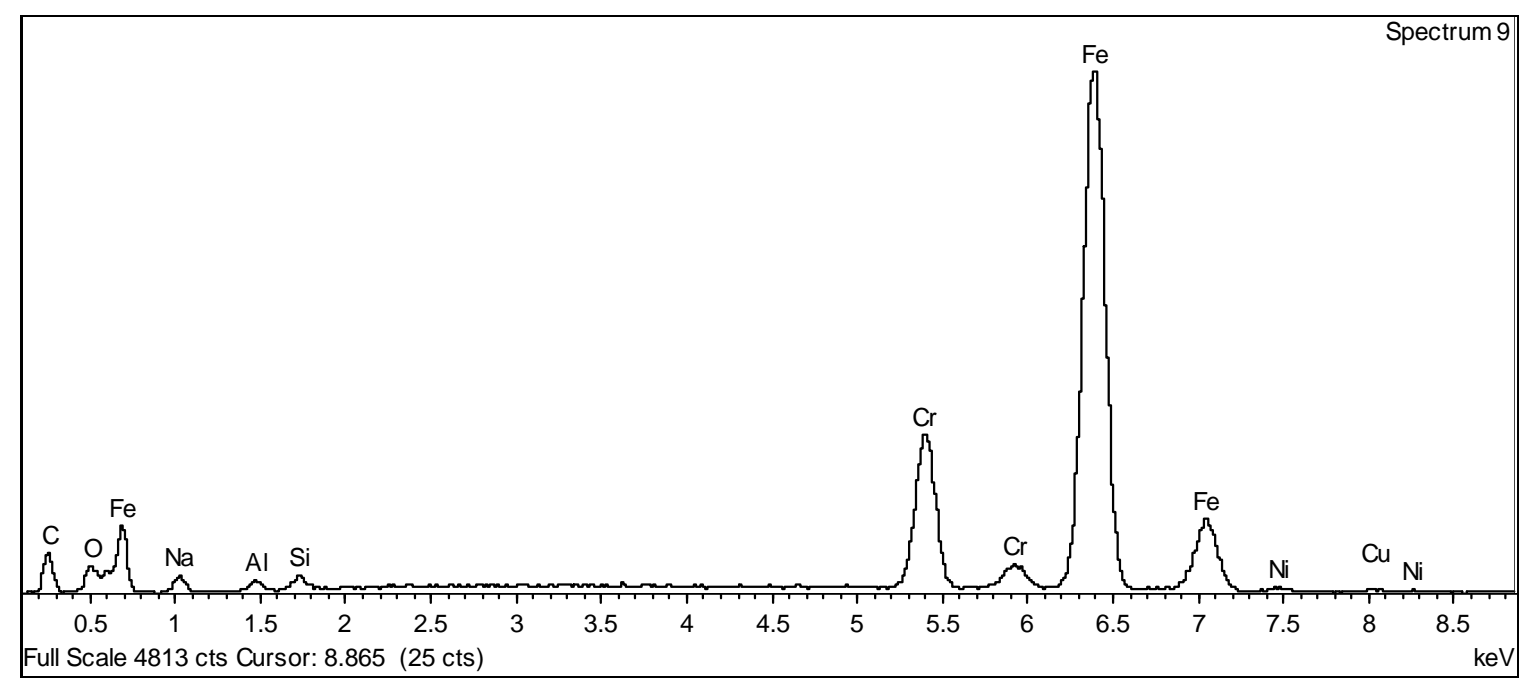

Figure 3.63 Spectrum of Spot 9 from Figure 3.61

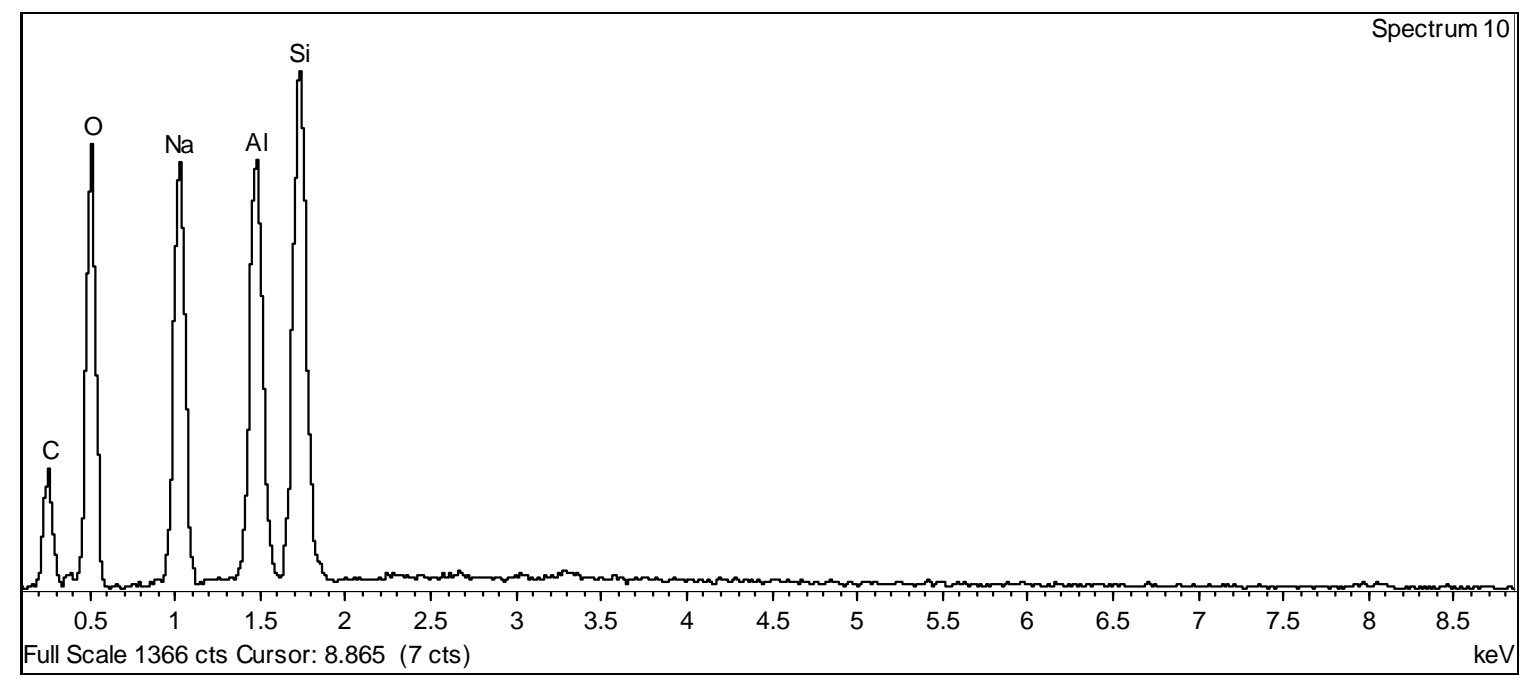

Figure 3.64 Spectrum of Spot 10 from Figure 3.61 


\subsection{DISCUSSION OF RESULTS}

\subsection{CHARACTERIZATION OF THE IP-35 SAMPLE FROM INSIDE THE DEHUMIDIFICATION DUCT (HTF-16-06-104)}

The chemical analysis of the solids of the sample from inside the dehumidification duct at $\mathrm{IP}-35$ indicates the presence of a large amount of $\mathrm{Na}$, some $\mathrm{Al}$, and smaller amounts of $\mathrm{Fe}$ and Si. Table 4-1 summarizes the composition of the major components of the solids using the data from the cesium hydroxide and peroxide fusion dissolutions of the dried solids contained in Tables 3-4 and 3-5. This data represents the total amount of these elements in the sample since the entire sample dissolves during the sample preparation. However, analysis of the solids in this manner will not allow determination of nitrate, nitrate, carbonate and other common species found in tank waste solutions and saltcake.

Table 4-1. Summary of the Solids Composition of Tank 16H Annulus Sample from IP-35 Inside the Dehumidification Duct (HTF-16-06-104)

\begin{tabular}{|l|c|c|}
\hline Analyte & Average & \%RSD \\
\hline Na wt \% & 18.9 & $1.9 \%$ \\
\hline Al wt \% & 8.93 & $12 \%$ \\
\hline Fe wt \% & 2.59 & $32 \%$ \\
\hline Si wt \% & 2.22 & $14 \%$ \\
\hline
\end{tabular}

The water contact of the solids allows determination of these simple salts. However, carbonate, nitrate or nitrite bound into water insoluble compounds will not dissolve and will not be detected. The results from the water contact of the solids from inside the dehumidification duct at IP-35 show a large fraction (see Section 4.4) of the sample to be soluble in water. Table 4-2 shows the major water-soluble components of the sample in units of weight percent of dried solids converted from Table 3-10.

Table 4-2 shows a larger soluble sodium value than the total sodium value in Table 4-1. The discrepancy may result from the higher uncertainties associated with sub-sampling damp solids composed of several different materials. Drying and finely grinding the material can reduce the error associated with sub-sampling this type of mixture, but can sometimes cause changes resulting in lowered solubility. Therefore, the sample was only broken up and mixed with a spatula. 
WSRC-STI-2008-00203, REV. 0

Table 4-2. Summary of the Water Soluble Fraction of the Tank 16H Annulus Sample from IP-35 Inside the Dehumidification Duct (HTF-16-06-104)

\begin{tabular}{|l|c|c|}
\hline Analyte & Average & \%RSD \\
\hline $\mathrm{Na}$ wt \% & 21.2 & $7.5 \%$ \\
\hline $\mathrm{NO}_{2}{ }^{-} \mathrm{wt} \%$ & 22.7 & $17 \%$ \\
\hline $\mathrm{NO}_{3}{ }^{-} \mathrm{wt} \%$ & 18.9 & $24 \%$ \\
\hline $\mathrm{CO}_{3}{ }^{2-} \mathrm{wt} \%$ & 1.76 & $24 \%$ \\
\hline $\mathrm{SO}_{4}{ }^{2-} \mathrm{wt} \%$ & 1.51 & $5.7 \%$ \\
\hline
\end{tabular}

The XRD data indicates the sample contains mainly sodium salts of carbonate, nitrate, and nitrite along with a small amount of aluminum hydroxide (Table 4-3). However, amorphous material will not be identified in the XRD and only rough estimates of the percentages for each phase identified can be obtained.

Table 4-3. Mineral Phases Identified in the Tank 16H Annulus Sample from IP-35 Inside the Dehumidification Duct (HTF-16-06-104)

\begin{tabular}{|l|c|}
\hline Mineral Phase & $\begin{array}{c}\text { Estimated } \\
\text { Percentage }\end{array}$ \\
\hline Trona (Hydrated Sodium Bicarbonate) $-\mathrm{Na}_{3} \mathrm{H}\left(\mathrm{CO}_{3}\right)_{2} \cdot 2 \mathrm{H}_{2} \mathrm{O}$ & $50 \%$ \\
\hline Sodium Nitrate $-\mathrm{NaNO}_{3}$ & $30 \%$ \\
\hline Sodium Nitrite $-\mathrm{NaNO}_{2}$ & $10 \%$ \\
\hline Bayerite $-\mathrm{Al}(\mathrm{OH})_{3}$ & $5 \%$ \\
\hline Gibbsite $-\mathrm{Al}(\mathrm{OH})_{3}$ & $5 \%$ \\
\hline
\end{tabular}

A simple calculation can be made to determine the weight percent of each element in a mixture containing the compounds listed in Table 4-3. The mixture would show a composition of 26.7 wt \% sodium, 26.6 wt \% carbonate, 21.9 wt \% nitrate, 6.7 wt \% nitrite, and $3.5 \mathrm{wt} \%$ aluminum. This result shows reasonable agreement with the results of the chemical analysis. However, the water contact of the sample shows a much lower value than the XRD result for carbonate and a much higher value for nitrite. The carbonate phase present in the solids may have only moderate to low water solubility, which could account for the difference in the results between the XRD and the water contact. The chemical analysis and the CSEM analysis of the sample indicate the presence of some silicate or aluminosilicate phases in the sample that were not observed in the XRD. The radiochemical composition of the samples can be obtained from Table 3-5. 


\subsection{CHARACTERIZATION OF THE IP-35 SAMPLE FROM OUTSIDE THE DEHUMIDIFICATION DUCT (HTF-16-06-105)}

The chemical analysis of the solids of the sample from outside the dehumidification duct at IP-35 shows a composition similar that of the sample from inside the duct but with considerably more silicon present. Table 4-4 summarizes the composition of the major components of the solids using the data from the cesium hydroxide and peroxide fusion dissolutions of the dried solids contained in Tables 3-6 and 3-7.

Table 4-4. Summary of the Solids Composition of Tank 16H Annulus Sample from IP-35 Outside the Dehumidification Duct (HTF-16-06-105)

\begin{tabular}{|l|c|c|}
\hline Analyte & Average & \%RSD \\
\hline Na wt \% & 20.5 & $25 \%$ \\
\hline Si wt \% & 11.2 & $12 \%$ \\
\hline Al wt \% & 5.32 & $12 \%$ \\
\hline Fe wt \% & 2.21 & $16 \%$ \\
\hline
\end{tabular}

The results from the water contact of the solids from outside the dehumidification duct at IP-35 show a large fraction of the sample to be soluble in water but less than observed with the sample from inside the duct. Table 4-5 shows the major water-soluble components of the sample in units of weight percent of dried solids converted from Table 3-11.

Table 4-5. Summary of the Water Soluble Fraction of the Tank 16H Annulus Sample from IP-35 Outside the Dehumidification Duct (HTF-16-06-105)

\begin{tabular}{|l|c|c|}
\hline Analyte & Average & \%RSD \\
\hline $\mathrm{Na}$ wt \% & 24.4 & $6.0 \%$ \\
\hline $\mathrm{NO}_{2}{ }^{-} \mathrm{wt} \%$ & 14.9 & $13 \%$ \\
\hline $\mathrm{NO}_{3}{ }^{-} \mathrm{wt} \%$ & 12.0 & $19 \%$ \\
\hline $\mathrm{CO}_{3}{ }^{2-} \mathrm{wt} \%$ & 2.96 & $3.5 \%$ \\
\hline $\mathrm{Si} \mathrm{wt}^{2} \%$ & 2.14 & $1.6 \%$ \\
\hline $\mathrm{SO}_{4}{ }^{2-} \mathrm{wt} \%$ & 1.14 & $13 \%$ \\
\hline
\end{tabular}


The XRD data indicates the sample contains mainly sodium salts of carbonate, nitrate, and nitrite along with a small amount of silicon containing phases. Table 4.6 provides the XRD data from the composite of all sections obtained from the sample. Table 4-7 shows the phases identified by the XRD analysis of Section C from the sample. This section of the sample contained solids that appeared much whiter in color than the rest of the sample. The XRD data for Section $\mathrm{C}$ shows this section of the sample contains a layer of mostly sodium nitrate and nitrite salts.

Table 4-6. Mineral Phases Identified in the Tank 16H Annulus Sample from IP-35 Outside the Dehumidification Duct (HTF-16-06-105 - Composite)

\begin{tabular}{|l|c|}
\hline Mineral Phase & $\begin{array}{c}\text { Estimated } \\
\text { Percentage }\end{array}$ \\
\hline Trona (Hydrated Sodium Bicarbonate) $-\mathrm{Na}_{3} \mathrm{H}\left(\mathrm{CO}_{3}\right)_{2} \cdot 2 \mathrm{H}_{2} \mathrm{O}$ & $70 \%$ \\
\hline Sodium Aluminum Nitrate Silicate Hydrate- $\mathrm{Na}_{3}\left(\mathrm{Al}_{6} \mathrm{Si}_{6} \mathrm{O}_{24}\right)\left(\mathrm{NO}_{3}\right)_{2} \cdot 4 \mathrm{H}_{2} \mathrm{O}$ & $10 \%$ \\
\hline Quartz-SiO & $10 \%$ \\
\hline Sodium Aluminum Silicate $-\mathrm{NaO} \cdot \mathrm{Al}_{2} \mathrm{O}_{3} \cdot \mathrm{SiO}_{2}$ & $10 \%$ \\
\hline
\end{tabular}

Table 4-7. Mineral Phases Identified in the Tank 16H Annulus Sample from IP-35 Outside the Dehumidification Duct (HTF-16-06-105 - Section C)

\begin{tabular}{|l|c|}
\hline Mineral Phase & $\begin{array}{c}\text { Estimated } \\
\text { Percentage }\end{array}$ \\
\hline Nitratine $-\mathrm{NaNO}_{3}$ & $50 \%$ \\
\hline Sodium Nitrite $-\mathrm{NaNO}_{2}$ & $30 \%$ \\
\hline Trona (Hydrated Sodium Bicarbonate) $-\mathrm{Na}_{3} \mathrm{H}\left(\mathrm{CO}_{3}\right)_{2} \cdot 2 \mathrm{H}_{2} \mathrm{O}$ & $20 \%$ \\
\hline
\end{tabular}

A simple calculation can be made to determine the weight percent of each element in a mixture listed in Table 4-6. This mixture would show a composition of $~ 23.2 \mathrm{wt} \%$ sodium, $37.2 \mathrm{wt} \%$ carbonate, $7.8 \mathrm{wt} \%$ silicon, $4.3 \mathrm{wt} \%$ aluminum, and $1.3 \mathrm{wt} \%$ nitrate. This result shows reasonable agreement with the results of the chemical analysis. However, the water contact of the sample shows a much lower value than the XRD result for carbonate and a much higher value for nitrate and nitrite. The CSEM data also appears consistent with both the chemical analysis and the XRD data. The radiochemical composition of the samples can be obtained from Table 3-7. 


\subsection{CHARACTERIZATION OF THE IP-118 SAMPLE FROM OUTSIDE THE DEHUMIDIFICATION DUCT (HTF-16-06-106)}

The chemical analysis of the solids of the sample from outside the dehumidification duct at IP-118 shows a composition similar to that of the sample from outside the duct at IP-35 but with more aluminum and less iron present. Table 4-8 summarizes the composition of the major components of the solids using the data from the cesium hydroxide and peroxide fusion dissolutions of the dried solids contained in Tables 3-8 and 3-9.

Table 4-8. Summary of the Solids Composition of Tank 16H Annulus Sample from IP-118 Outside the Dehumidification Duct (HTF-16-06-106)

\begin{tabular}{|l|c|c|}
\hline Analyte & Average & \%RSD \\
\hline Na wt \% & 21.2 & $5.7 \%$ \\
\hline Si wt \% & 11.6 & $11 \%$ \\
\hline Al wt \% & 10.4 & $10 \%$ \\
\hline Fe wt \% & 0.21 & $20 \%$ \\
\hline
\end{tabular}

The results from the water contact of the solids from outside the dehumidification duct at IP-118 show a small amount of the sample to be soluble in water. Table 4-9 shows the major water-soluble components of the sample in units of weight percent of dried solids converted from Table 3-12. The amount of soluble sodium salts appears to be much lower in this sample than the other two IP-35 samples.

Table 4-9. Summary of the Water Soluble Fraction of the Tank 16H Annulus Sample from IP-118 Outside the Dehumidification Duct (HTF-16-06-106)

\begin{tabular}{|l|c|c|}
\hline Analyte & Average & \%RSD \\
\hline $\mathrm{Na}$ wt \% & 12.9 & $6.3 \%$ \\
\hline $\mathrm{NO}_{2}{ }^{-} \mathrm{wt} \%$ & 8.05 & $0.4 \%$ \\
\hline $\mathrm{NO}_{3}{ }^{-} \mathrm{wt} \%$ & 5.07 & $1.0 \%$ \\
\hline $\mathrm{CO}_{3}{ }^{2-} \mathrm{wt} \%$ & 2.16 & $4.7 \%$ \\
\hline
\end{tabular}

The XRD data indicates the sample contains mainly sodium aluminum nitrate silicate hydrate phase. Table 4.10 provides the XRD data from the top section obtained from the sample (Section D). Table 4-11 shows the phases identified by the XRD analysis of bottom section of the sample (Section A). The XRD data shows both sections of the sample to be similar although the bottom section of the sample contains a small amount of nitrate and nitrite phases. 
Table 4-10. Mineral Phases Identified in the Tank 16H Annulus Sample from IP-118 Outside the Dehumidification Duct (HTF-16-06-106 - Section D)

\begin{tabular}{|l|c|}
\hline Mineral Phase & $\begin{array}{c}\text { Estimated } \\
\text { Percentage }\end{array}$ \\
\hline Sodium Aluminum Nitrate Silicate Hydrate- $\mathrm{Na}_{3}\left(\mathrm{Al}_{6} \mathrm{Si}_{6} \mathrm{O}_{24}\right)\left(\mathrm{NO}_{3}\right)_{2} \cdot 4 \mathrm{H}_{2} \mathrm{O}$ & $95 \%$ \\
\hline Muscovite-3T - $(\mathrm{K}, \mathrm{Na})(\mathrm{Al}, \mathrm{Mg}, \mathrm{Fe})\left(\mathrm{Si}_{1.3} \mathrm{O}_{0.9}\right) \mathrm{O}_{10}(\mathrm{OH})_{2}$ & $10 \%$ \\
\hline
\end{tabular}

Table 4-11. Mineral Phases Identified in the Tank 16H Annulus Sample from IP-118 Outside the Dehumidification Duct (HTF-16-06-106 - Section A)

\begin{tabular}{|l|c|}
\hline Mineral Phase & $\begin{array}{c}\text { Estimated } \\
\text { Percentage }\end{array}$ \\
\hline Sodium Aluminum Nitrate Silicate Hydrate- $\mathrm{Na}_{3}\left(\mathrm{Al}_{6} \mathrm{Si}_{6} \mathrm{O}_{24}\right)\left(\mathrm{NO}_{3}\right)_{2} \cdot 4 \mathrm{H}_{2} \mathrm{O}$ & $75 \%$ \\
\hline Sodium Nitrite $-\mathrm{NaNO}_{2}$ & $10 \%$ \\
\hline Muscovite-3T - $(\mathrm{K}, \mathrm{Na})(\mathrm{Al}, \mathrm{Mg}, \mathrm{Fe})\left(\mathrm{Si}_{1.3} \mathrm{O}_{0.9}\right) \mathrm{O}_{10}(\mathrm{OH})_{2}$ & $5 \%$ \\
\hline Quartz-SiO & $5 \%$ \\
\hline Nitratine $-\mathrm{NaNO}_{3}$ & $5 \%$ \\
\hline
\end{tabular}

A simple calculation can be made to determine the weight percent of each element in a mixture listed in Table 4-10 and 4-11. The mixture in Table 4-10 would show a composition of $\sim 6.7 \mathrm{wt} \%$ sodium, $12.0 \mathrm{wt} \%$ nitrate, $16.4 \mathrm{wt} \%$ silicon, and $15.7 \mathrm{wt} \%$ aluminum. For the mixture in Table 4-11 composition would contain 10.0 wt \% sodium, $13.1 \mathrm{wt} \%$ nitrate, 6.7 wt \% nitrite, $15.3 \mathrm{wt} \%$ silicon, and $12.4 \mathrm{wt} \%$ aluminum. This XRD results show reasonable agreement with the chemical analysis, however the chemical analysis shows higher total sodium. The CSEM data also appears consistent with both the chemical analysis and the XRD data. The radiochemical composition of the samples can be obtained from Table 3-9. 


\subsection{ESTIMATED WATER SOLUBILITY OF THE TANK 16H ANNULUS SAMPLES}

An estimate of the solubility of the material in these samples can be obtained from the analytical results of the water contact. A direct measurement of the solubility of the material in these samples was not part of the task ${ }^{3}$, so only an estimate can be provided based on the available data. The estimate was previously issued in a memorandum. ${ }^{10}$

Using the results of the analysis of the water contacts, the mass of solids contacted, the volume of water used, and the wt \% solids for each sample, a rough estimate of the mass of material that dissolved in the water contacts can be calculated. The calculation also assumes the anions concentrations measured in the water contact samples are present as sodium salts in the solutions. Table 4.12 shows the results of the calculations.

\section{Table 4-12. Estimate of the Solubility of the Material in the Tank 16H Annulus Samples}

\begin{tabular}{|l|c|c|}
\hline Sample ID & $\begin{array}{c}\text { Estimated wt \% of Total } \\
\text { Dried Solids Soluble in } \\
\text { Water }\end{array}$ & Sample Location in Annulus \\
\hline HTF-16-06-104 & $60-70$ & Sample from IP-35 inside of duct \\
\hline HTF-16-06-105 & $45-65$ & Sample from IP-35 outside of duct \\
\hline HTF-16-06-106 & $25-35$ & Sample from IP-118 outside of duct \\
\hline
\end{tabular}

*The wt \% solids for all three samples were between $81 \%$ and $93 \%$ indicating very little water was present in the samples. Therefore, the values shown in the table on a wt \% of total dried solids basis are essentially the wt $\%$ of the sample soluble in water.

The X-Ray Diffraction (XRD) data can be used as a qualitative check on the solubility estimates. Table 4-13 shows the phases identified in each of the three samples and a rough approximation of the percentage of each phase present in the samples. The second column indicates whether the mineral phase might be expected to be soluble in water. From the XRD data, HTF-16-06-106 should have the lowest solubility, HTF-16-06-104 the greatest solubility, and HTF-16-06-105 somewhere in between. 
WSRC-STI-2008-00203, REV. 0

Table 4-13. XRD results for the Tank 16H Annulus Samples

\begin{tabular}{|l|c|c|c|c|}
\hline $\begin{array}{l}\text { Mineral Phases Identified } \\
\text { Water? }\end{array}$ & $\begin{array}{c}\text { Soluble } \\
\text { in } \\
\text { Warcentage found } \\
\text { in } \\
\text { HTF-16-06-104 }\end{array}$ & $\begin{array}{c}\text { Percentage found } \\
\text { in } \\
\text { HTF-16-06-105 }\end{array}$ & $\begin{array}{c}\text { Percentage found } \\
\text { in } \\
\text { HTF-16-06-106 }\end{array}$ \\
\hline $\begin{array}{l}\text { Sodium Aluminum Nitrate } \\
\text { Silicate Hydrate }\end{array}$ & No & $0 \%$ & $10 \%$ & $75 \%$ \\
\hline Sodium Aluminum Silicate & No & $0 \%$ & $10 \%$ & $0 \%$ \\
\hline Quartz - $\mathrm{SiO}_{2}$ & No & $0 \%$ & $10 \%$ & $5 \%$ \\
\hline $\begin{array}{l}\text { Trona - Hydrated Sodium } \\
\text { Bicarbonate }\end{array}$ & Yes & $50 \%$ & $70 \%$ & $0 \%$ \\
\hline Sodium Nitrate & Yes & $30 \%$ & $0 \%$ & $5 \%$ \\
\hline Sodium $\mathrm{Nitrite}$ & Yes & $10 \%$ & $0 \%$ & $10 \%$ \\
\hline Bayerite $\mathrm{Al}(\mathrm{OH})_{3}$ & No & $5 \%$ & $0 \%$ & $0 \%$ \\
\hline Gibbsite $\mathrm{Al}(\mathrm{OH})_{3}$ & No & $5 \%$ & $0 \%$ & $0 \%$ \\
\hline
\end{tabular}

\subsection{CONCLUSIONS}

The three samples obtained from the Tank $16 \mathrm{H}$ annulus show some similarity as to the types of mineral phases present in the materials but differ in the relative amounts of each phase present. The sample from inside the dehumidification duct at IP-35 contains more water soluble material than the other two samples as might be expected since this material would be less accessible to the washing/waste removal done in the annulus in the past. The sample from outside the duct at IP-35 shows more water insoluble material than the sample from inside the duct. Interestingly, the sample from outside the duct at IP-118 contains much more water insoluble material than the sample from outside the duct at IP-35. This may indicate that washing was more effective in the IP-118 area of the annulus. Alternatively, the aluminosilicates in the waste may have formed as a result of the sand left behind from sandblasting operations conducted in the annulus. The sand acts as a reservoir of silica that under high $\mathrm{pH}$ conditions can react with the aluminum to form aluminosilicates. The higher aluminosilicate content in the sample from IP-118 might be a result of a higher concentration of sand in this area of the annulus. The IP-118 sample also shows a small difference in composition from the top to the bottom of the sample. The bottom section of the sample appears to contain more water soluble material than the top based on the XRD data. This aspect of the sample again seems reasonable since the material at the bottom of the annulus would also be less accessible to the washing/waste removal conducted in the annulus. The samples from outside the dehumidification duct at two locations in the annulus show very different compositions and estimated solubility in water. This indicates the waste material in Tank $16 \mathrm{H}$ annulus may have a wide range of compositions at different locations. 
WSRC-STI-2008-00203, REV. 0

Table 4-14. Simplified Composition of the Tank 16H Annulus Samples

\begin{tabular}{|l|c|c|c|}
\hline Mineral Phases & $\begin{array}{c}\text { Fraction found in } \\
\text { HTF-16-06-104 }\end{array}$ & $\begin{array}{c}\text { Fraction found in } \\
\text { HTF-16-06-105 }\end{array}$ & $\begin{array}{c}\text { Fraction found in } \\
\text { HTF-16-06-106 }\end{array}$ \\
\hline Sodium Aluminum Silicates/Sand & small fraction & large fraction & large fraction \\
\hline Aluminum Hydroxides & moderate fraction & small fraction & moderate fraction \\
\hline Sodium Carbonates & large fraction & large fraction & small fraction \\
\hline Sodium Nitrate/Nitrite & large fraction & moderate fraction & moderate fraction \\
\hline
\end{tabular}

Small fraction $<5 \%$, Moderate fraction $>5 \%$ to $<30 \%$, Large fraction $>30 \%$

Based on the results of the characterization of the three Tank $16 \mathrm{H}$ annulus samples, Table 4-14 provides a simplified description of the composition of each sample. The limited characterization techniques available and the complex mixture of materials in each sample make assigning a definitive composition for each sample difficult. The data obtained from the total sample digestions (cesium hydroxide and sodium peroxide fusions) provides a maximum concentration for a few elements and radionuclides in the sample. The water contact results provide a minimum concentration for a few other species in the sample. The XRD provides identification of the major crystalline phases present in the samples and a rough estimate of the percentage of each phase. The CSEM results provide additional qualitative identification of elemental compositions. All of the data taken together does not provide a complete understanding of the composition but does give a good description of the types of material likely to be encountered in the annulus waste. Given the variability in composition with just the three small samples characterized, a more detailed description of any single sample may be of limited value. 


\subsection{REFERENCES}

1. W. R. West, R. S. Waltz, J. B. Elder, “Evaluation of Tank 16 Annulus Inspections 3/05/07-3/29/07”, LWO-LWE-2007-00085, May 22, 2007.

2. Q. L. Nguyen, “Tank 16 Annulus Sampling Characterization”, HLE-TTR-2006-011, October 17. 2006.

3. M. S. Hay, “Task Technical and Quality Assurance Plan for Characterization of Samples from Tank 16H Annulus”, WSRC-RP-2006-00844, October 17, 2006.

4. M. S. Hay, "Analytical Study Plan for the Characterization of Tank $16 H$ Annulus Samples”, SRNL-CST-2006-00087, October 31, 2006.

5. Q. L. Nguyen, “Evaluation and Pathforward on Taking Sample from IP-262”, LWOPIT-2007-00016, February 7, 2007.

6. M. S. Hay, "Results of the Characterization and Dissolution Tests of Samples from Tank 16H”, WSRC-RP-99-00124, January 19, 1999.

7. L. Reynolds, “Summary of Current Data on Tank 16H Annulus Samples”, DPST-79360, January 9, 1979.

8. C. J. Coleman, R. A. Dewberry, M. F. Bryant, J. J. Gemmill, "SRL's Performance in Round Robin \#6 - Analysis of Simulated Defense Waste Glass (U)”, WSRC-TR-91-187, Rev. 0, May 31, 1991.

9. M. S. Hay, T. B. Edwards, "Statistical Analysis of ESP Verification Test Samples”, WSRC-RP-94-1224, November 4, 1994.

10. M. S. Hay, “Estimated Solubility of Tank 16H Annulus Samples”, SRNL-CST-200700065, June 14, 2007. 
WSRC-STI-2008-00203, REV. 0

\section{APPENDIX A}

(Additional CSEM Micrographs and EDX Spectra) 


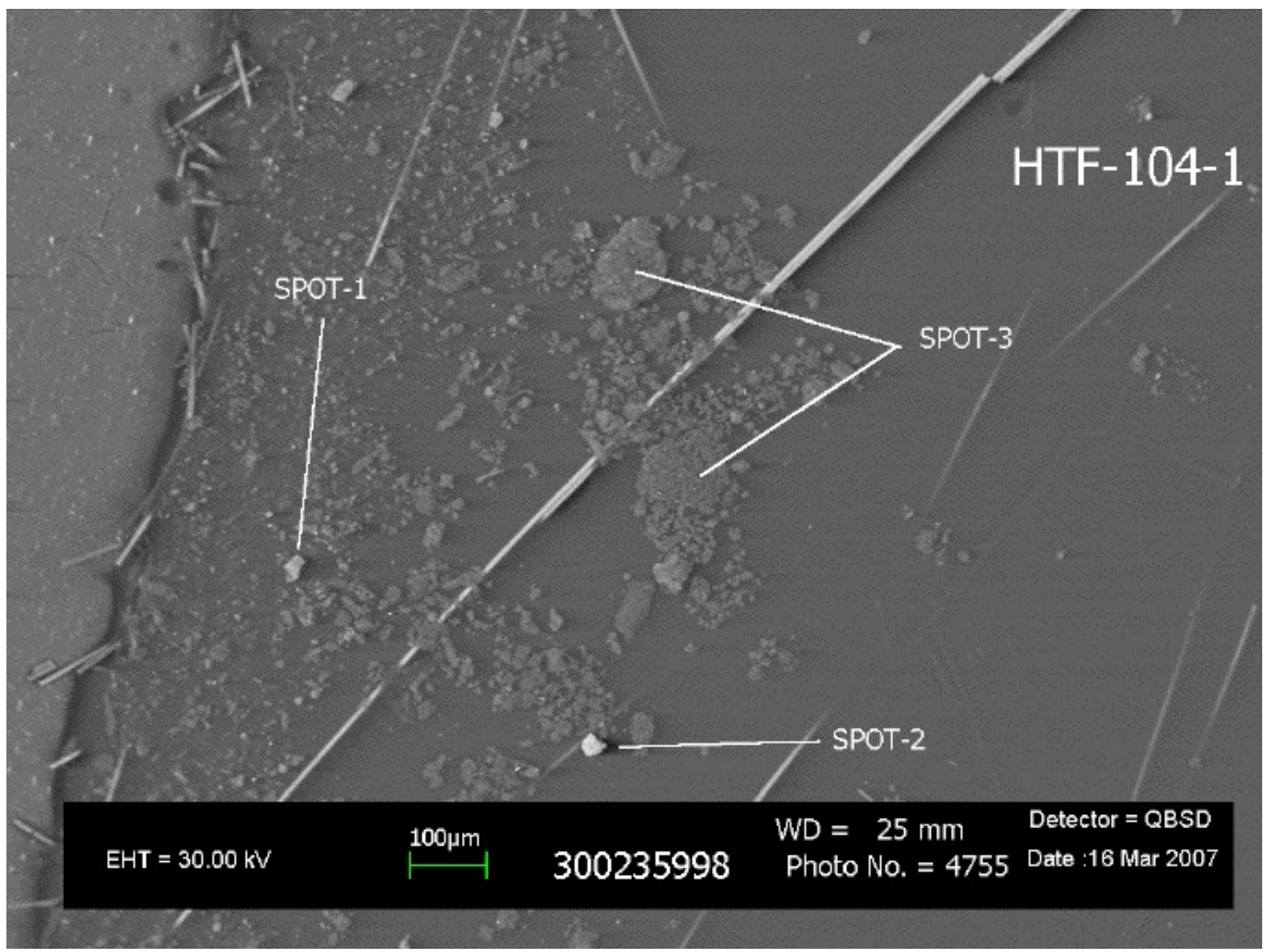

Figure A.1 SEM Micrograph of Solids from Tank 16H Sample HTF-16-06-104-1 (69X Magnification)

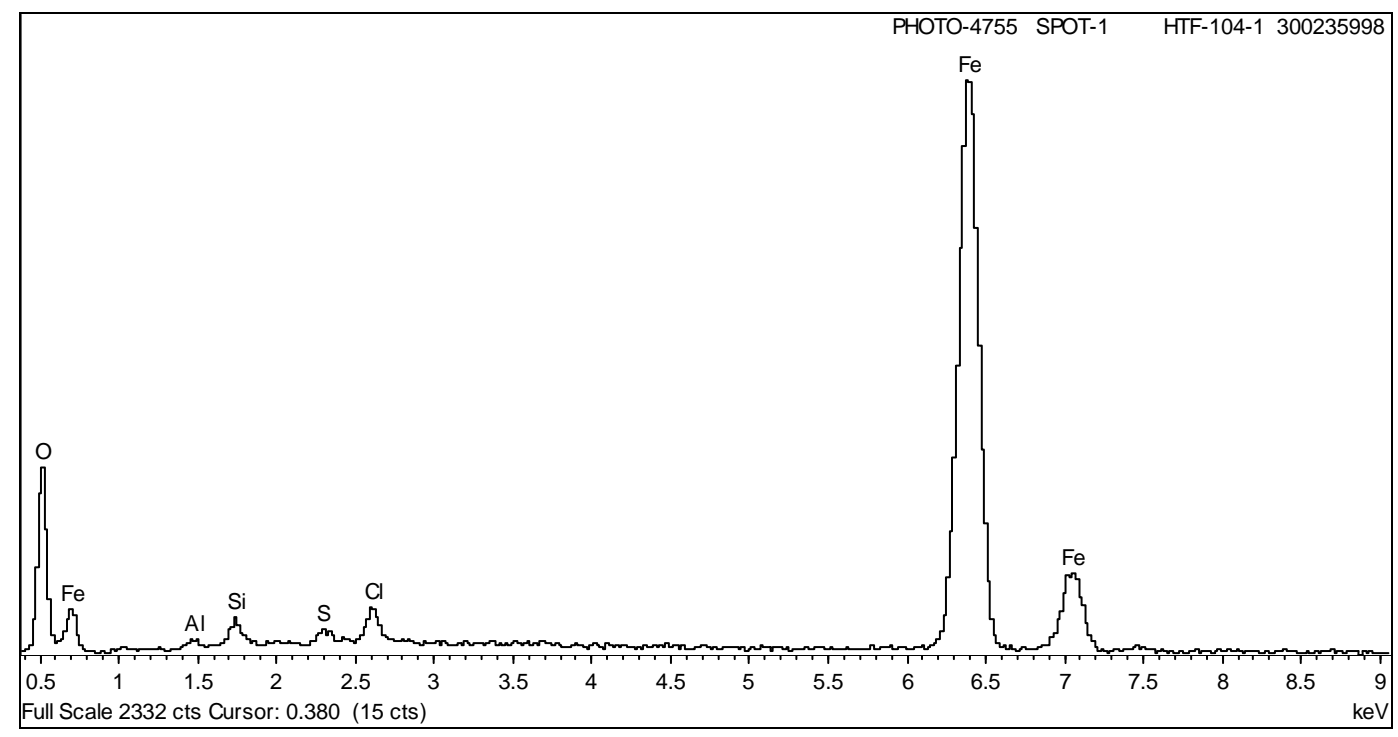

Figure A.2 Spectrum of Spot 1 from Figure A.1 
WSRC-STI-2008-00203, REV. 0

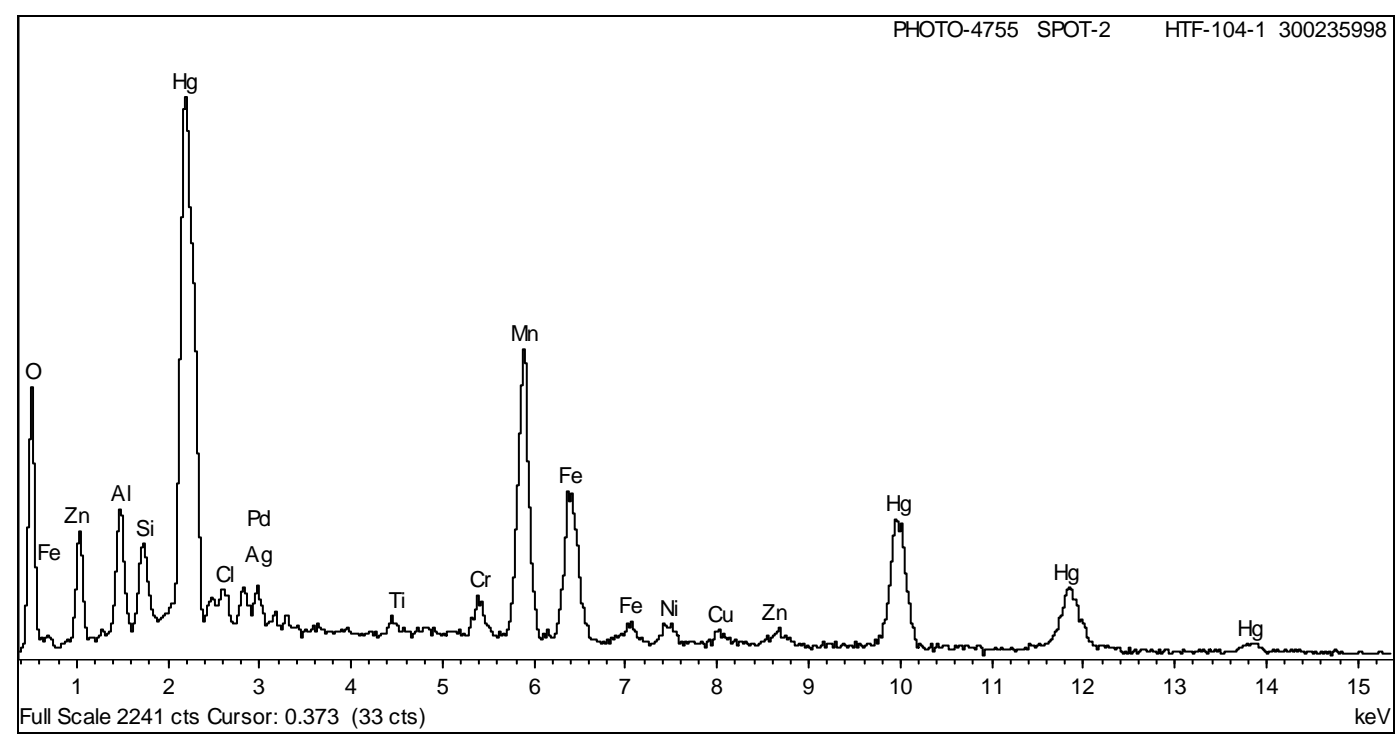

Figure A.3 Spectrum of Spot 2 from Figure A.1

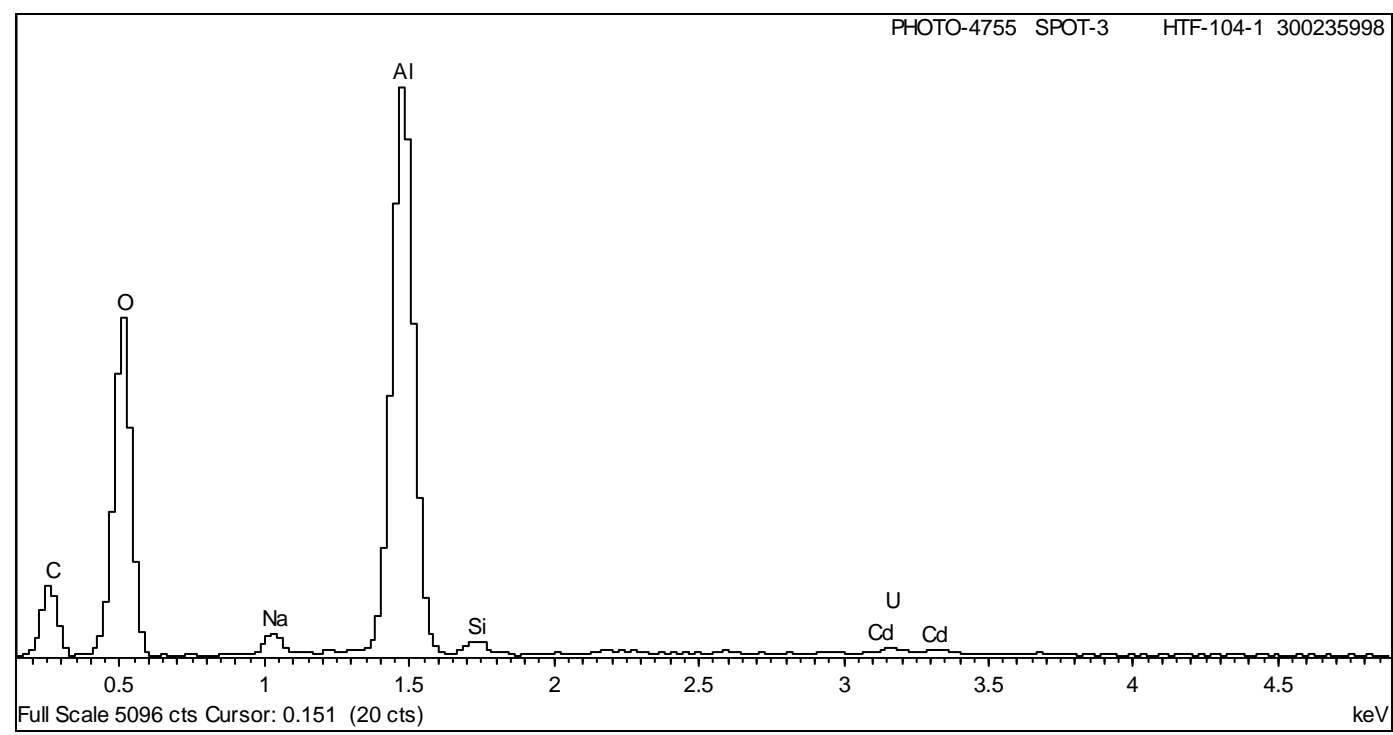

Figure A.4 Spectrum of Spot 3 from Figure A.1 


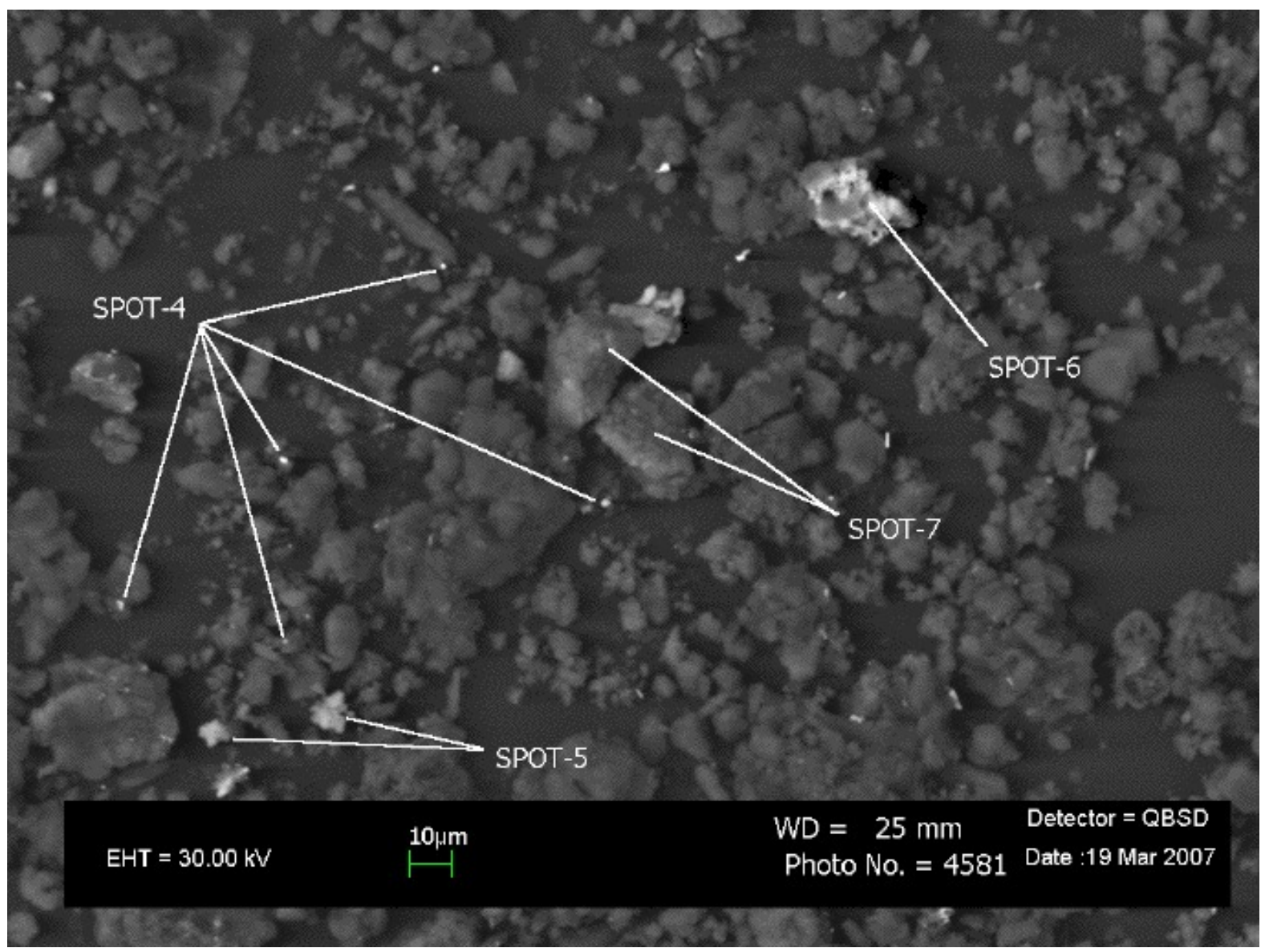

Figure A.5 SEM Micrograph of Solids from Tank 16H Sample HTF-16-06-104-1 (375X Magnification)

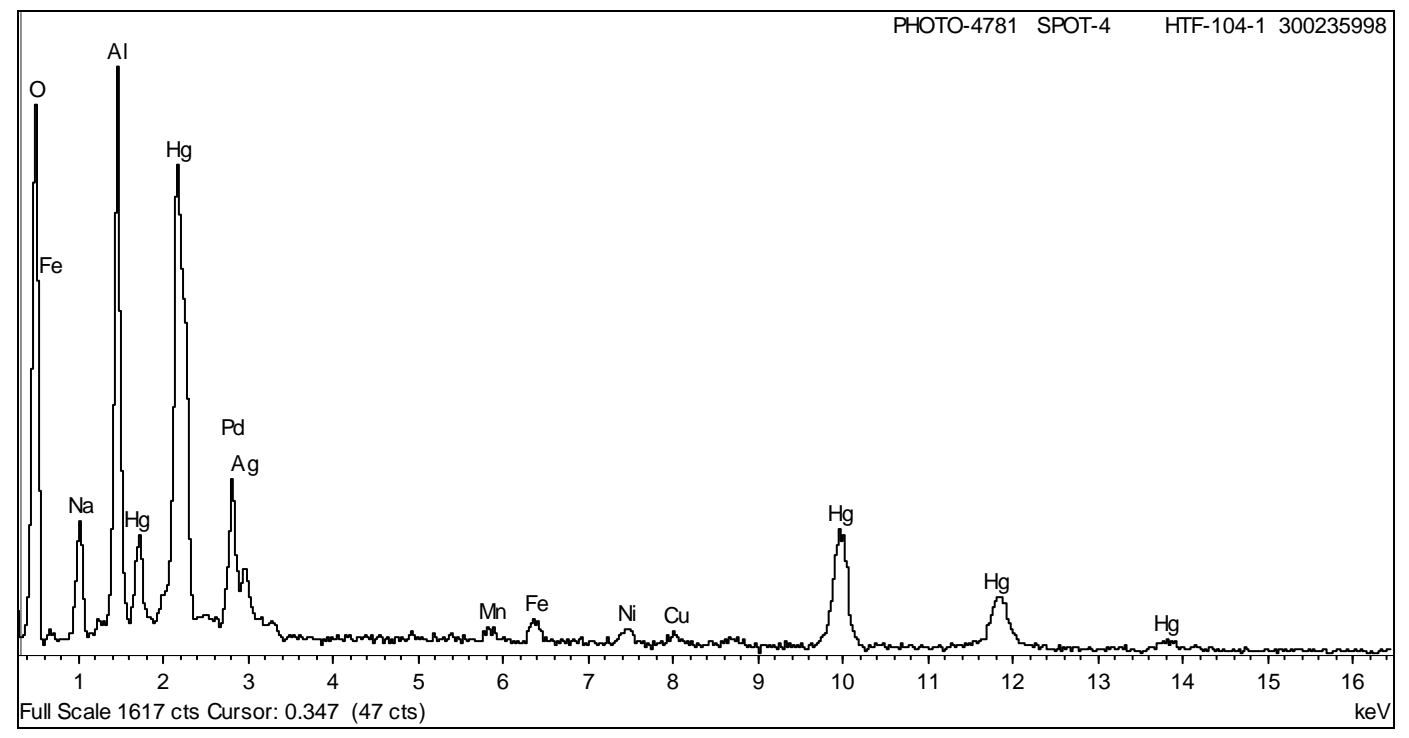

Figure A.6 Spectrum of Spot 4 from Figure A.5 
WSRC-STI-2008-00203, REV. 0

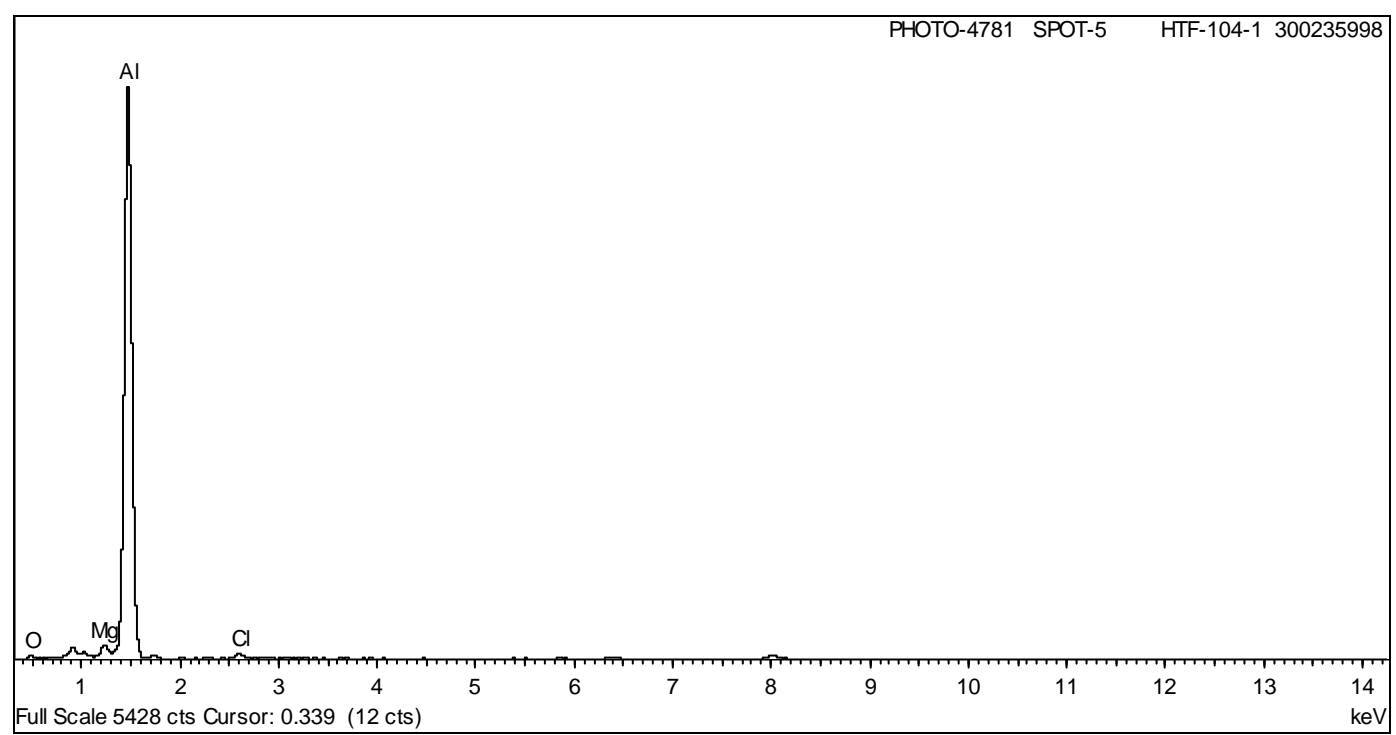

Figure A.7 Spectrum of Spot 5 from Figure A.5

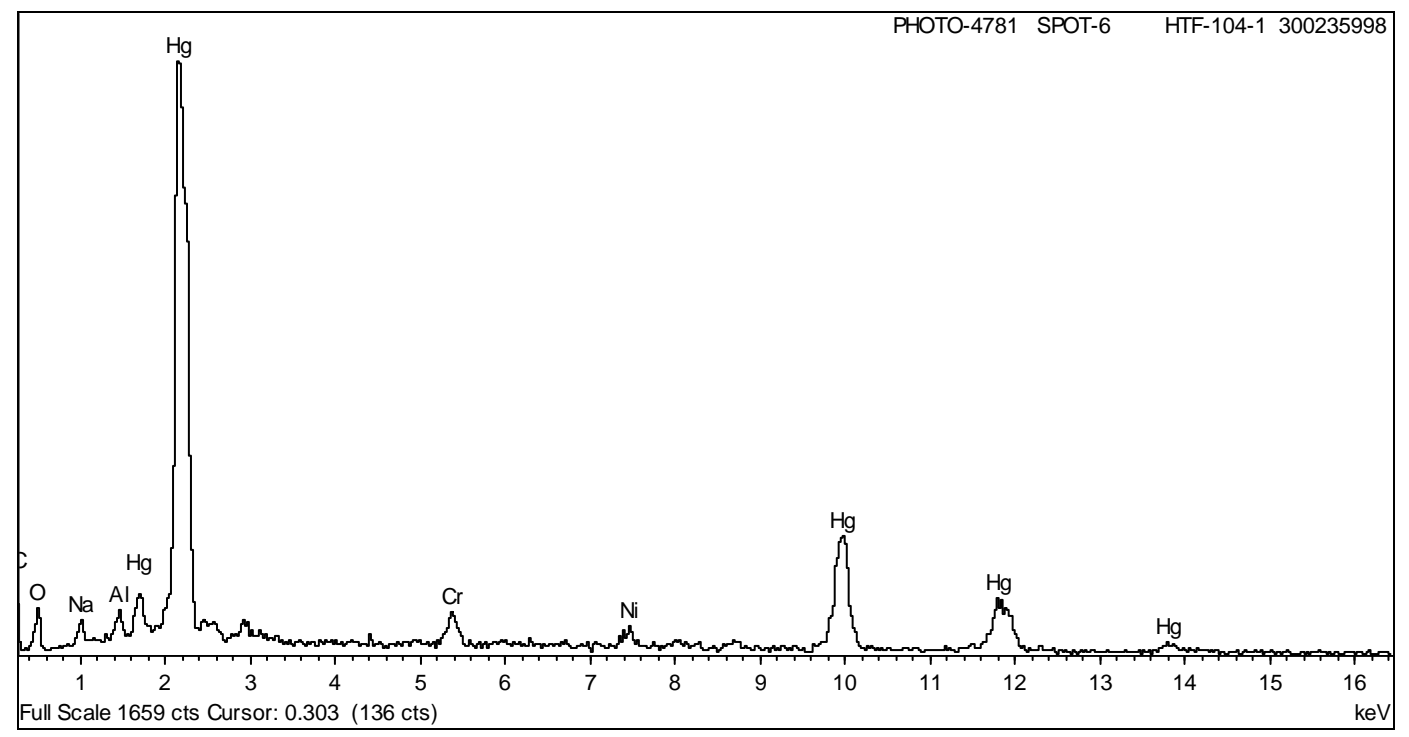

Figure A.8 Spectrum of Spot 6 from Figure A.5 
WSRC-STI-2008-00203, REV. 0

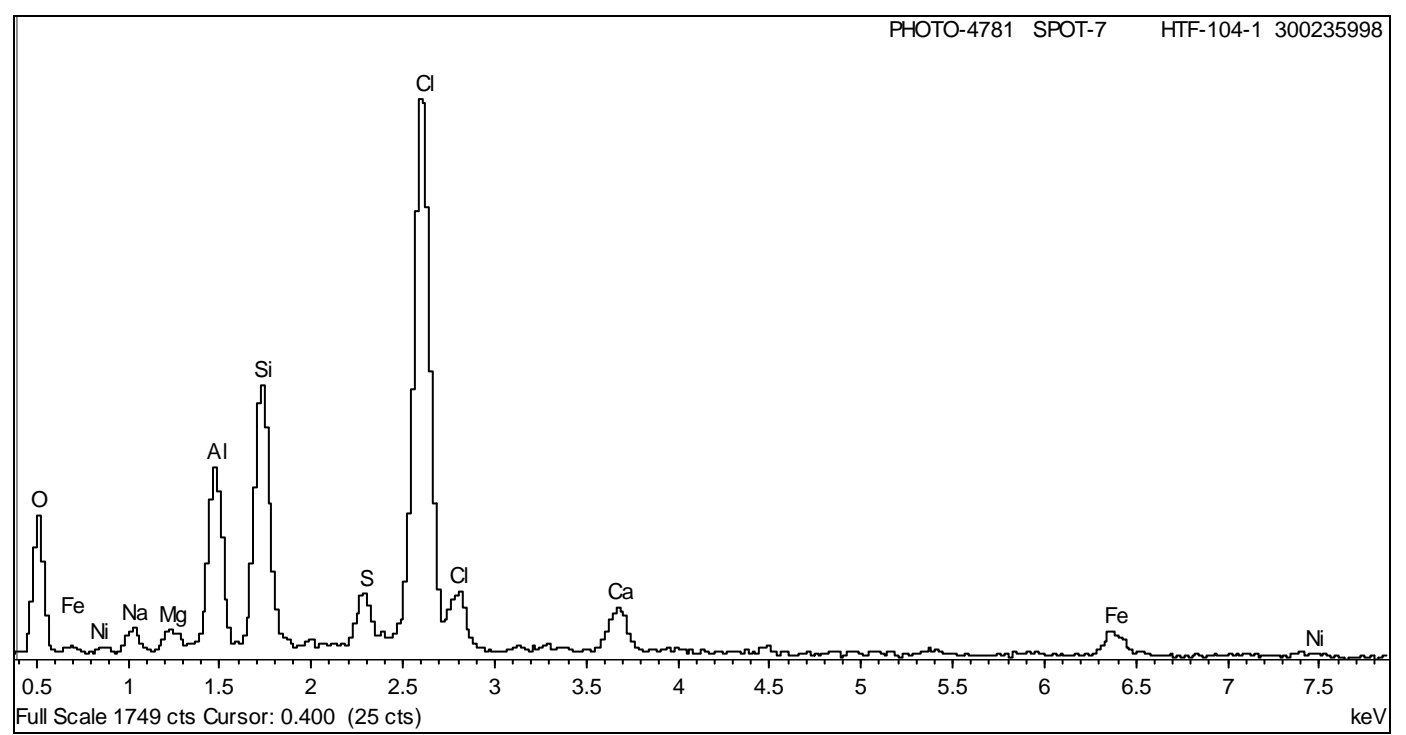

Figure A.8 Spectrum of Spot 7 from Figure A.5 


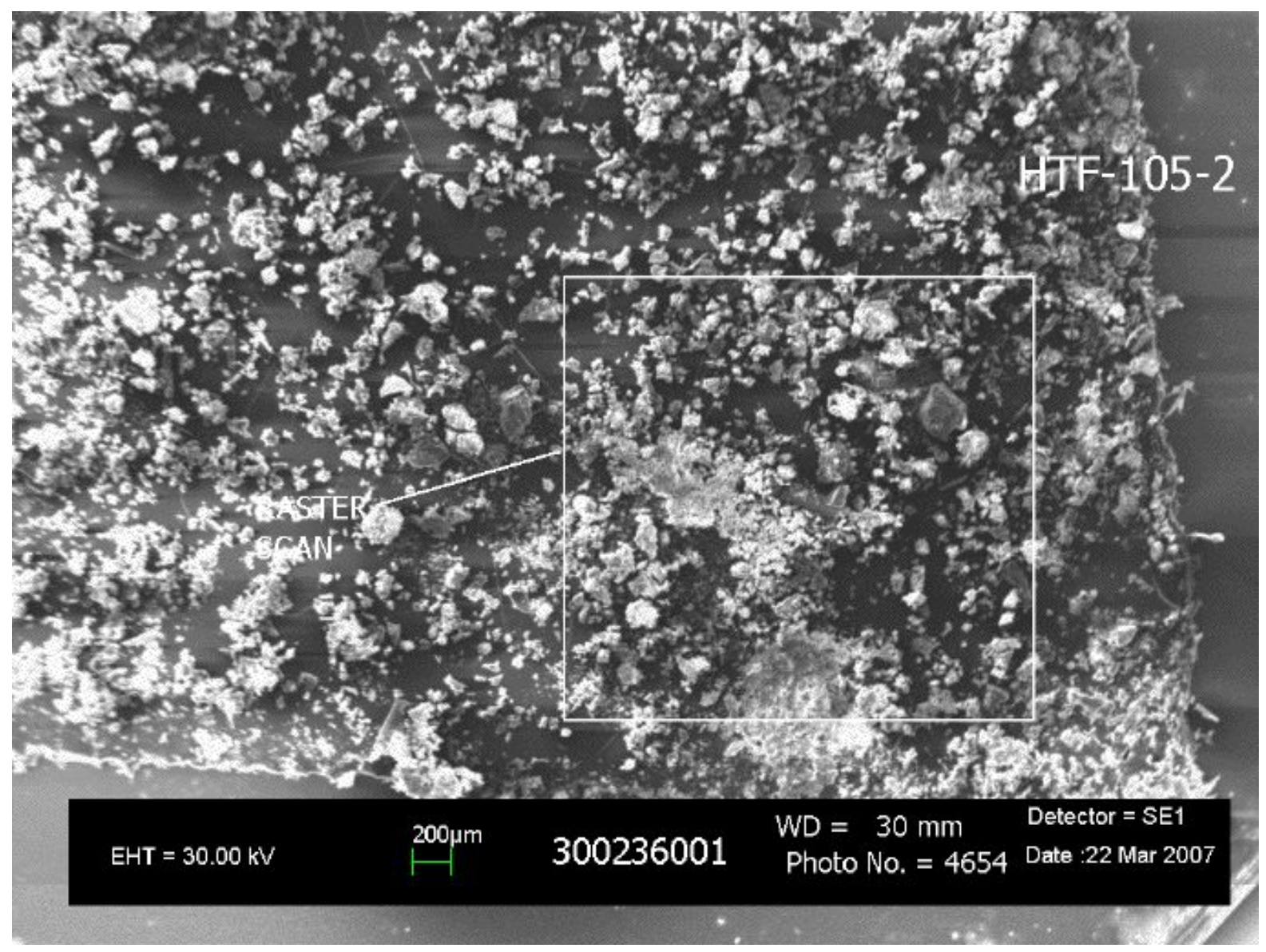

Figure A.9 SEM Micrograph of Solids from Tank 16H Sample HTF-16-06-105-2 (18X Magnification)

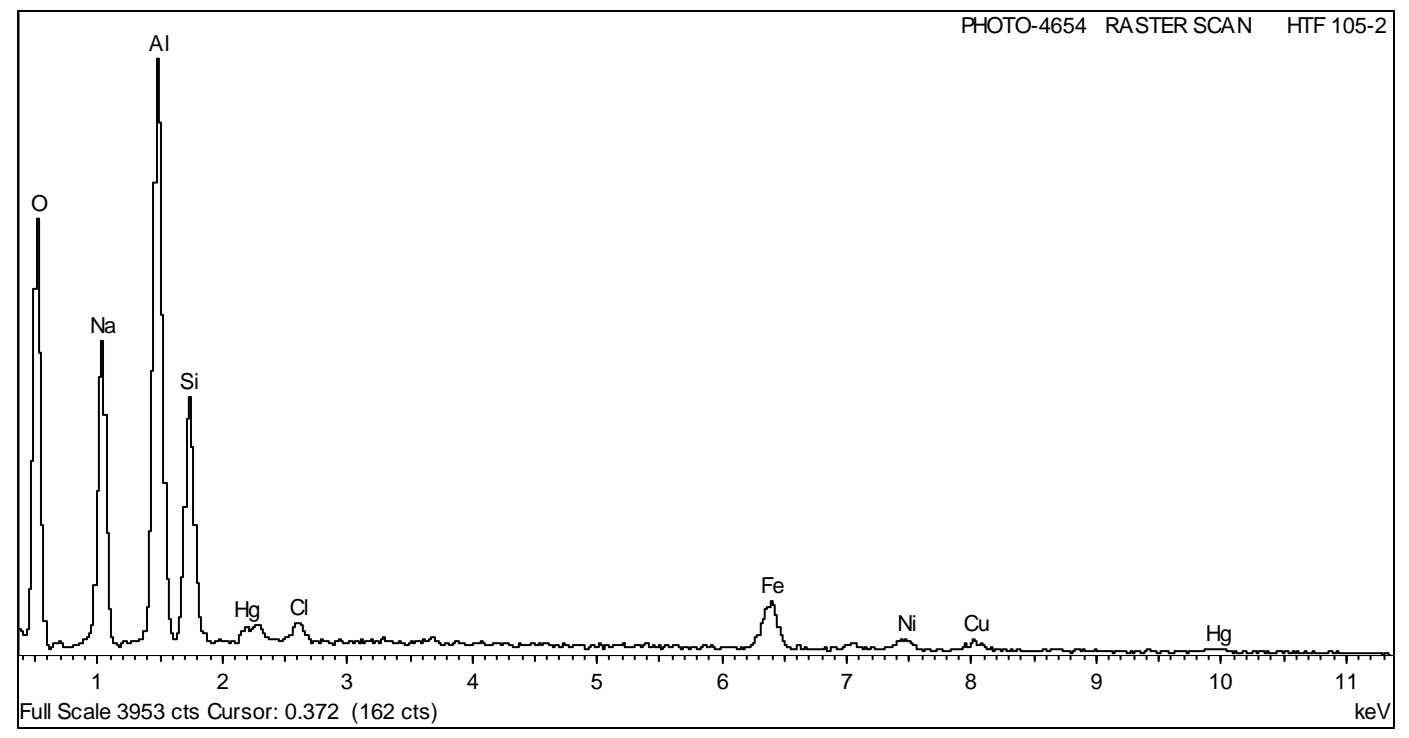

Figure A.10 Spectrum of Raster Scan from Figure A.9 


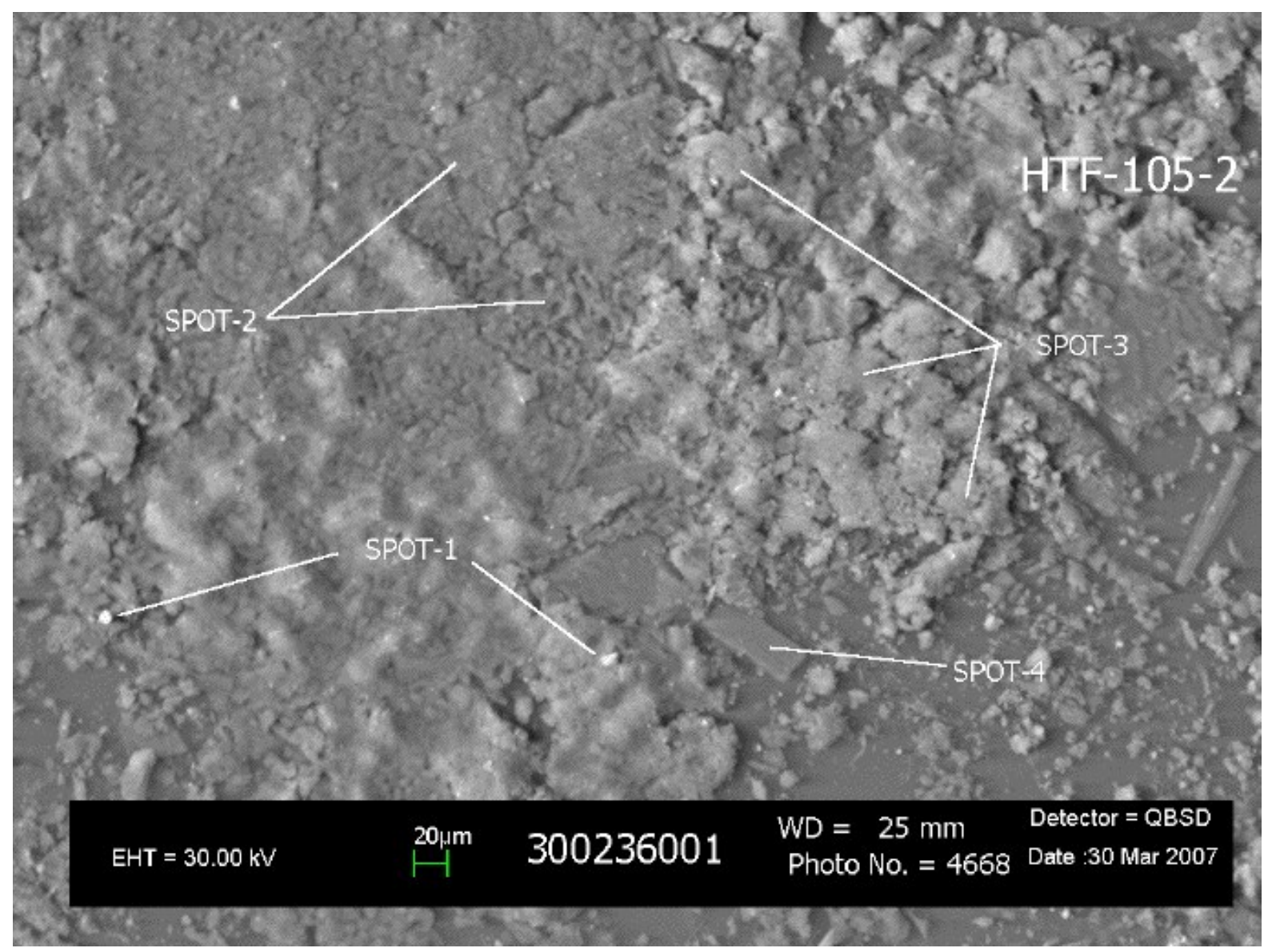

Figure A.11 SEM Micrograph of Solids from Tank 16H Sample HTF-16-06-105-2 (150X Magnification)

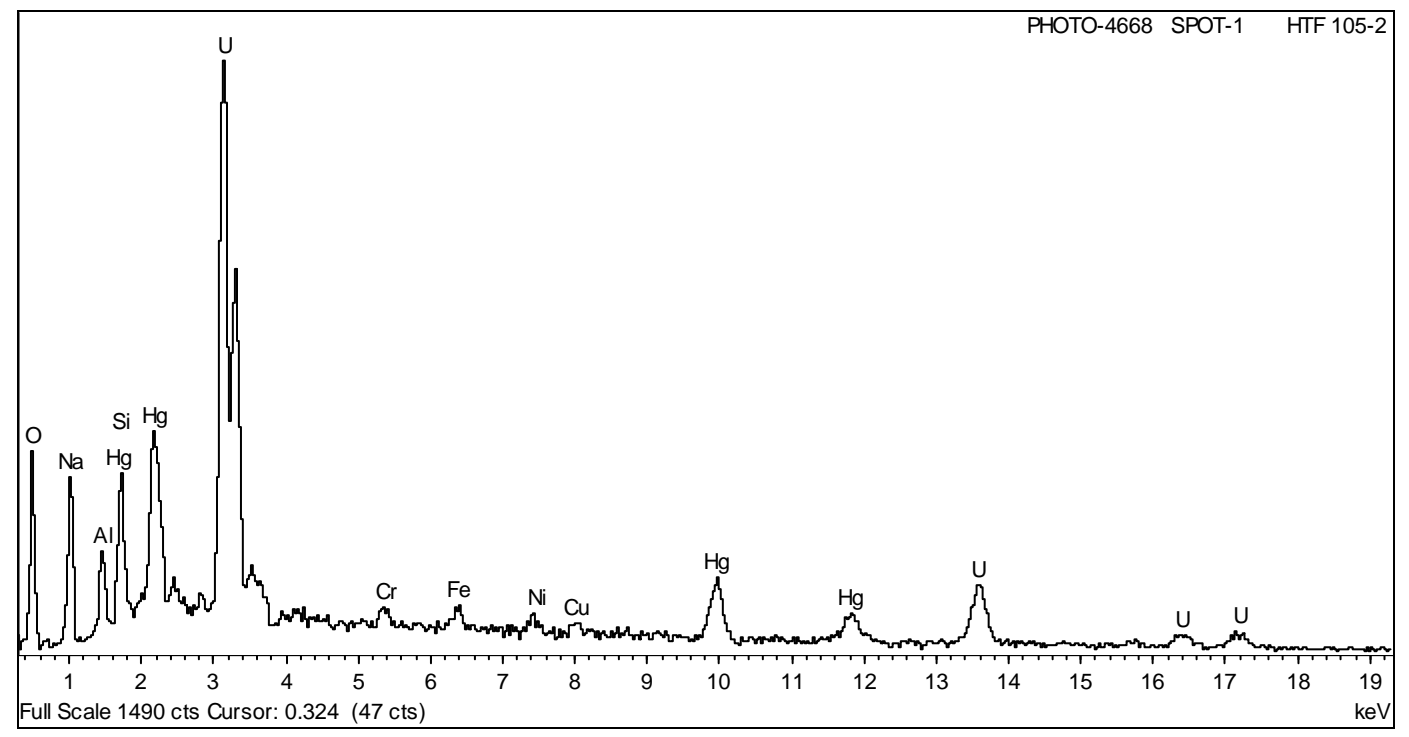

Figure A.12 Spectrum of Spot 1 from Figure A.11 
WSRC-STI-2008-00203, REV. 0

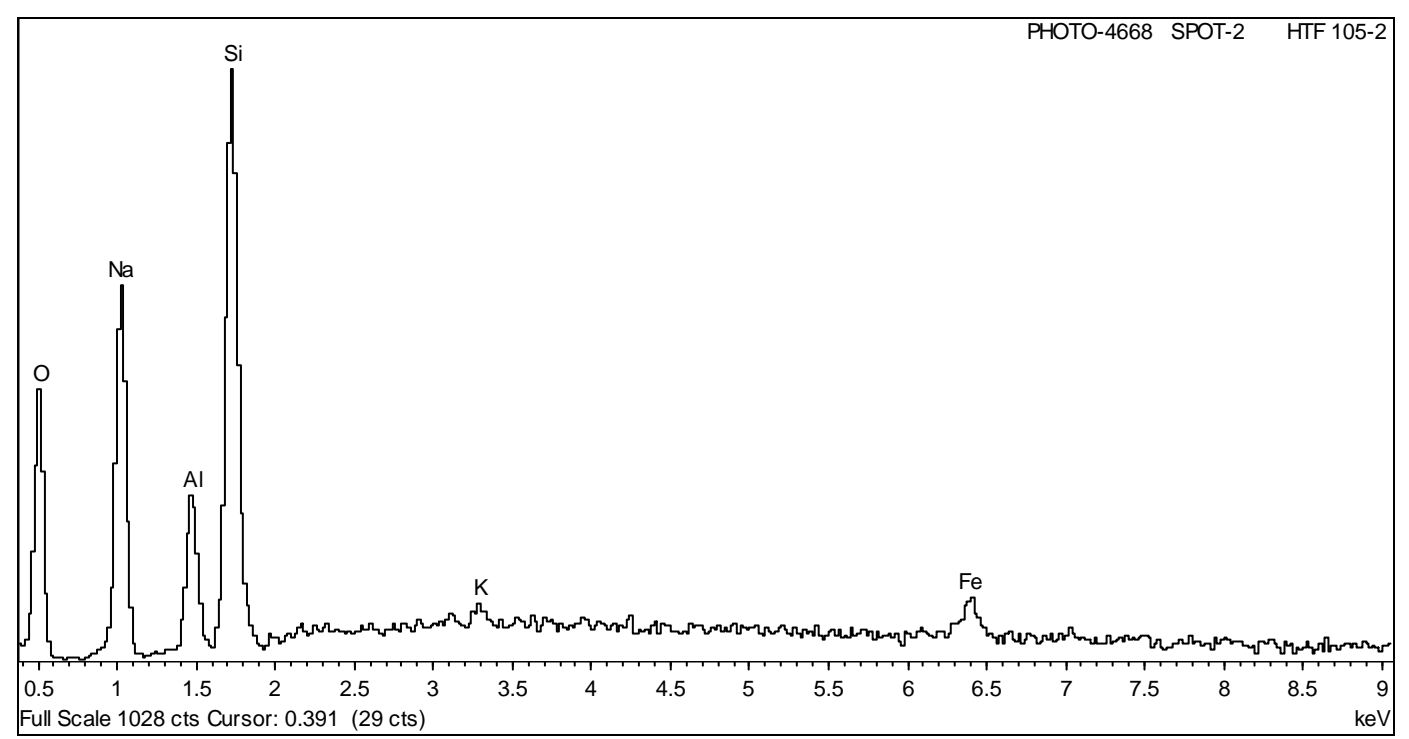

Figure A.13 Spectrum of Spot 2 from Figure A.11

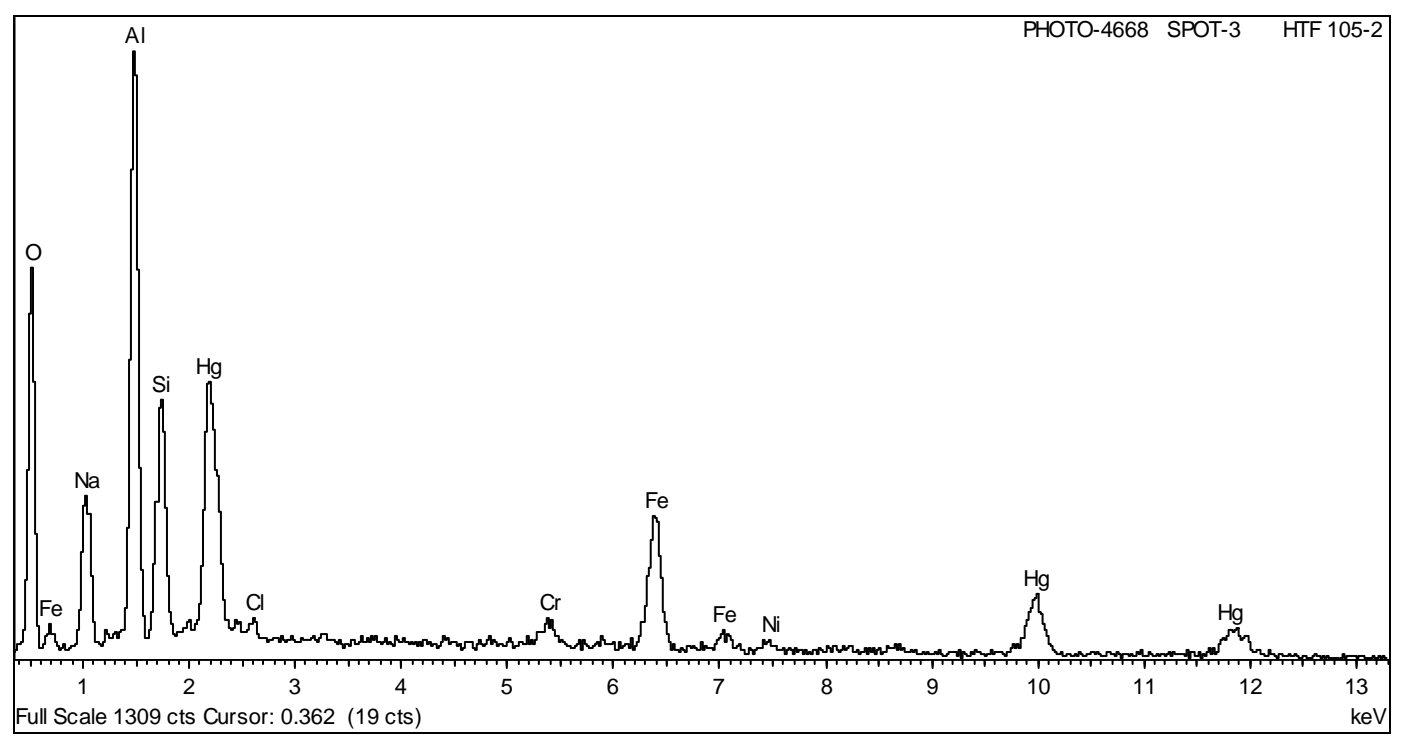

Figure A.14 Spectrum of Spot 3 from Figure A.11 
WSRC-STI-2008-00203, REV. 0

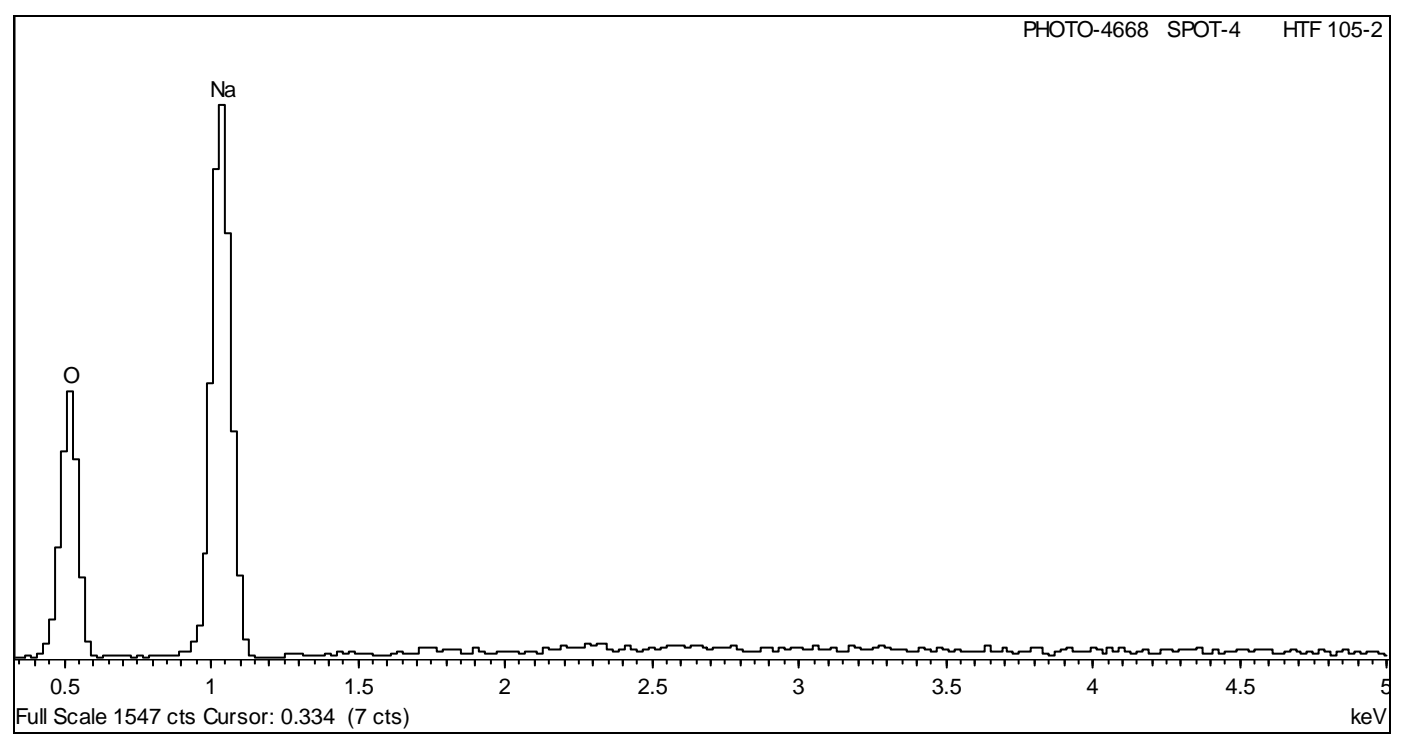

Figure A.15 Spectrum of Spot 4 from Figure A.11 


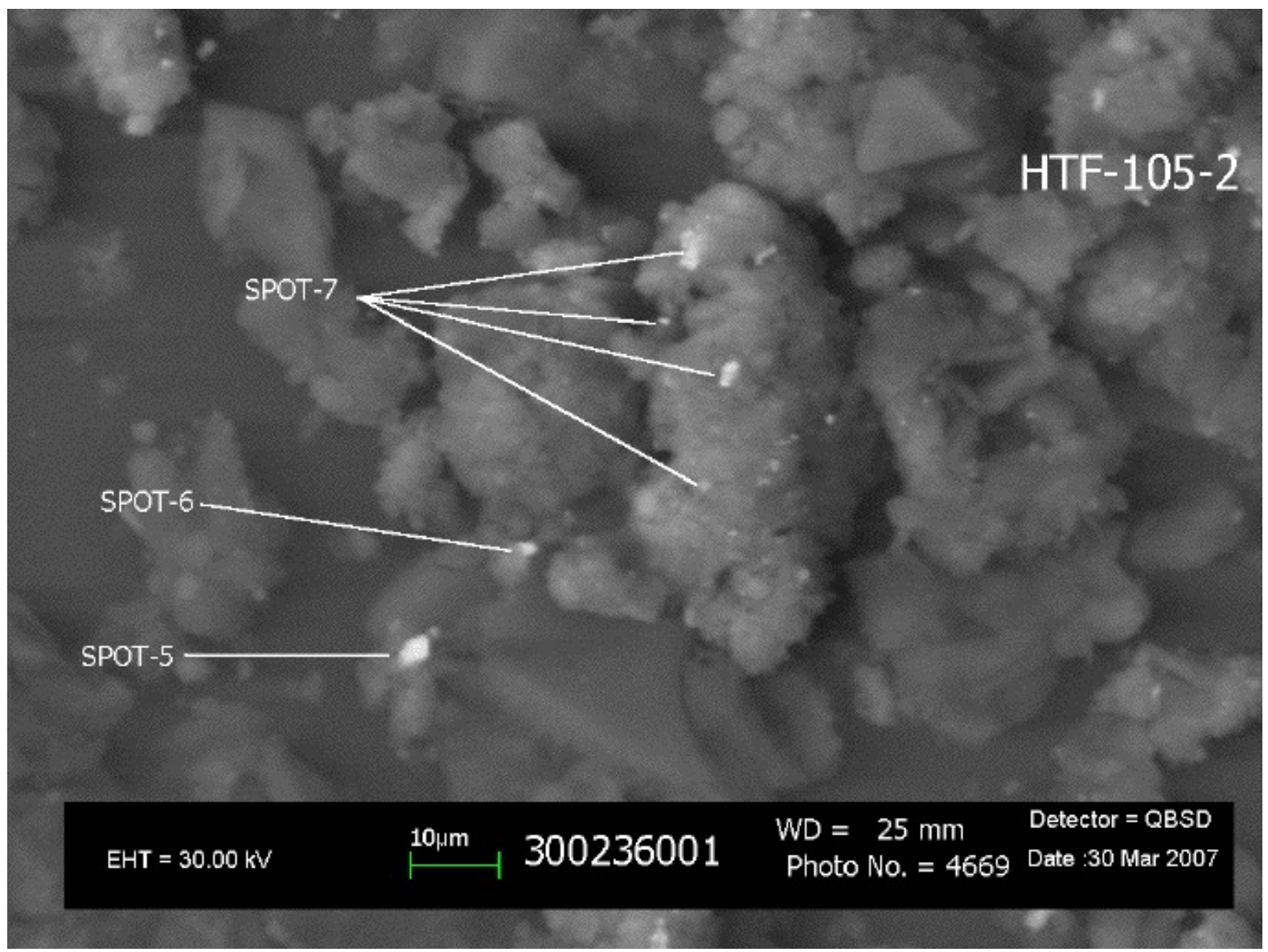

Figure A.16 SEM Micrograph of Solids from Tank 16H Sample HTF-16-06-105-2 (800X Magnification)

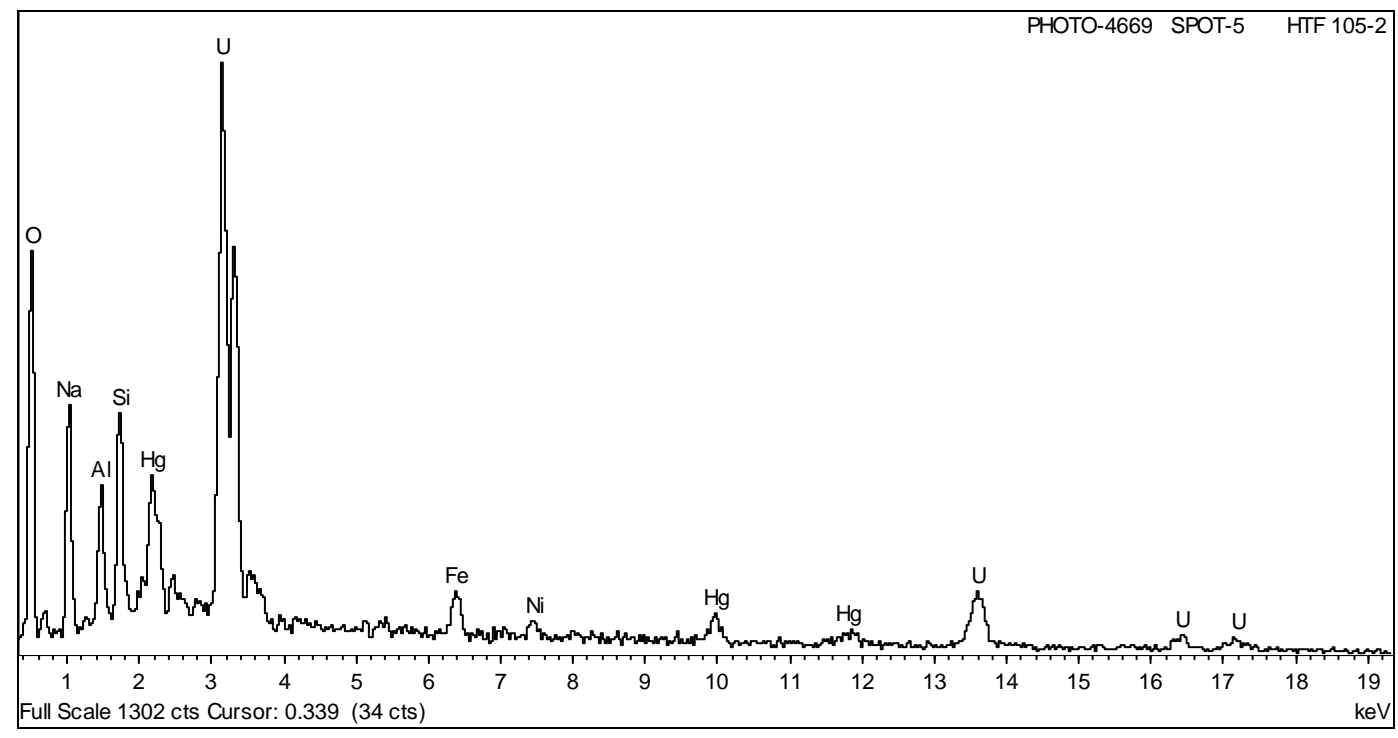

Figure A.17 Spectrum of Spot 5 from Figure A.16 
WSRC-STI-2008-00203, REV. 0

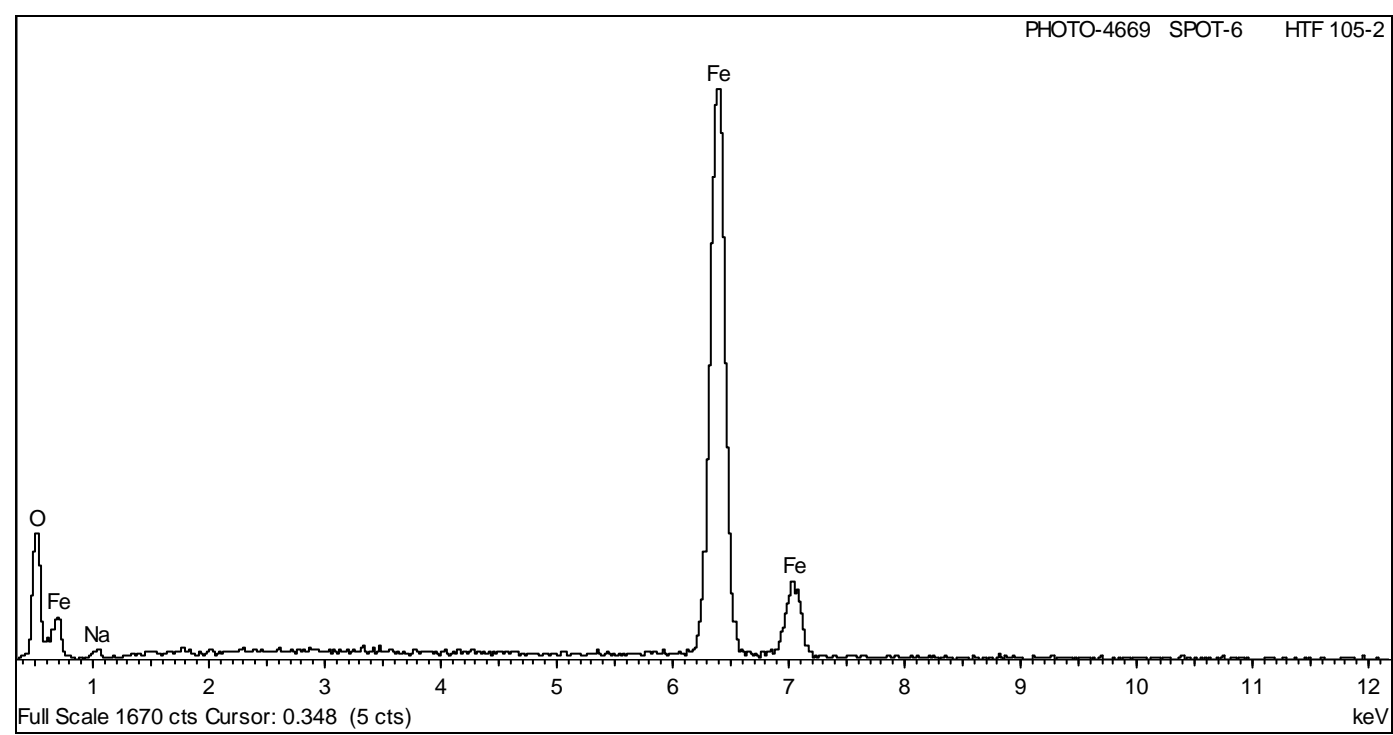

Figure A.18 Spectrum of Spot 6 from Figure A.16

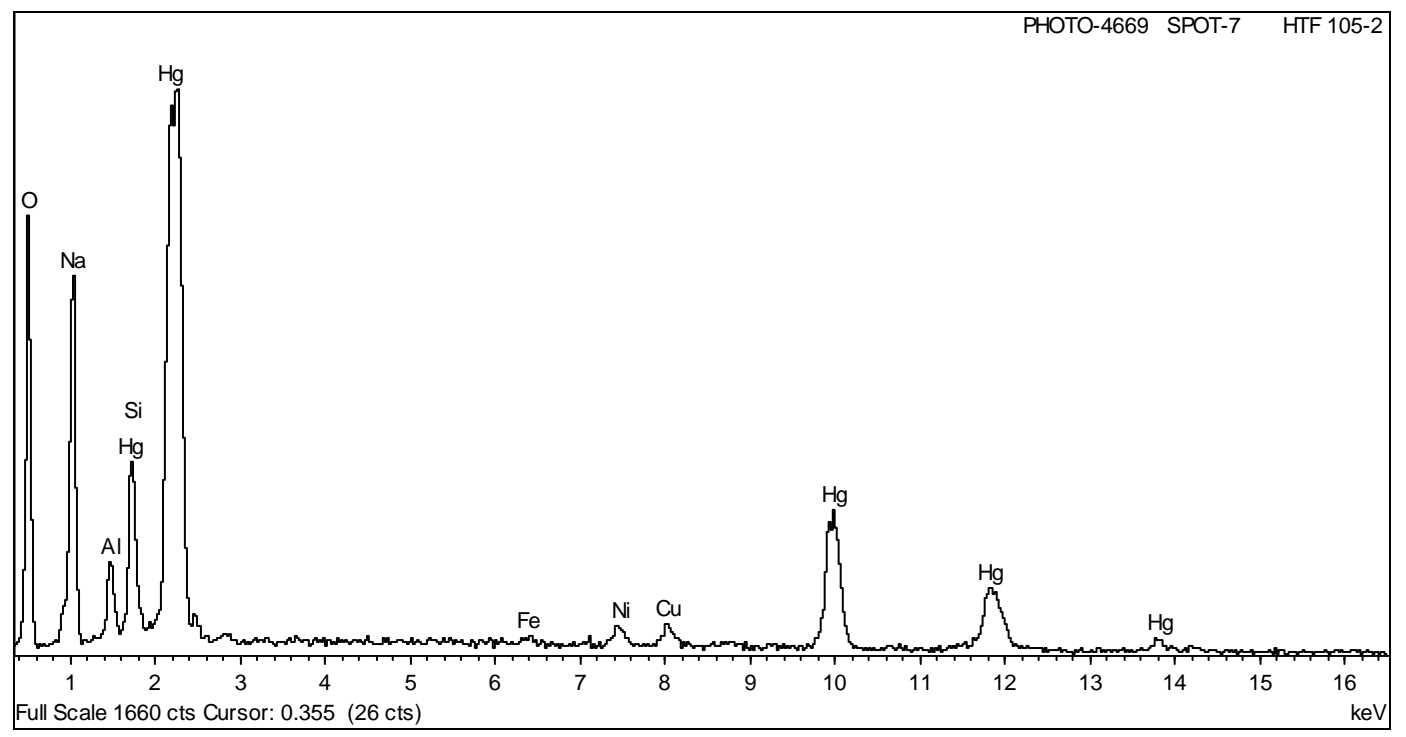

Figure A.19 Spectrum of Spot 7 from Figure A.16 


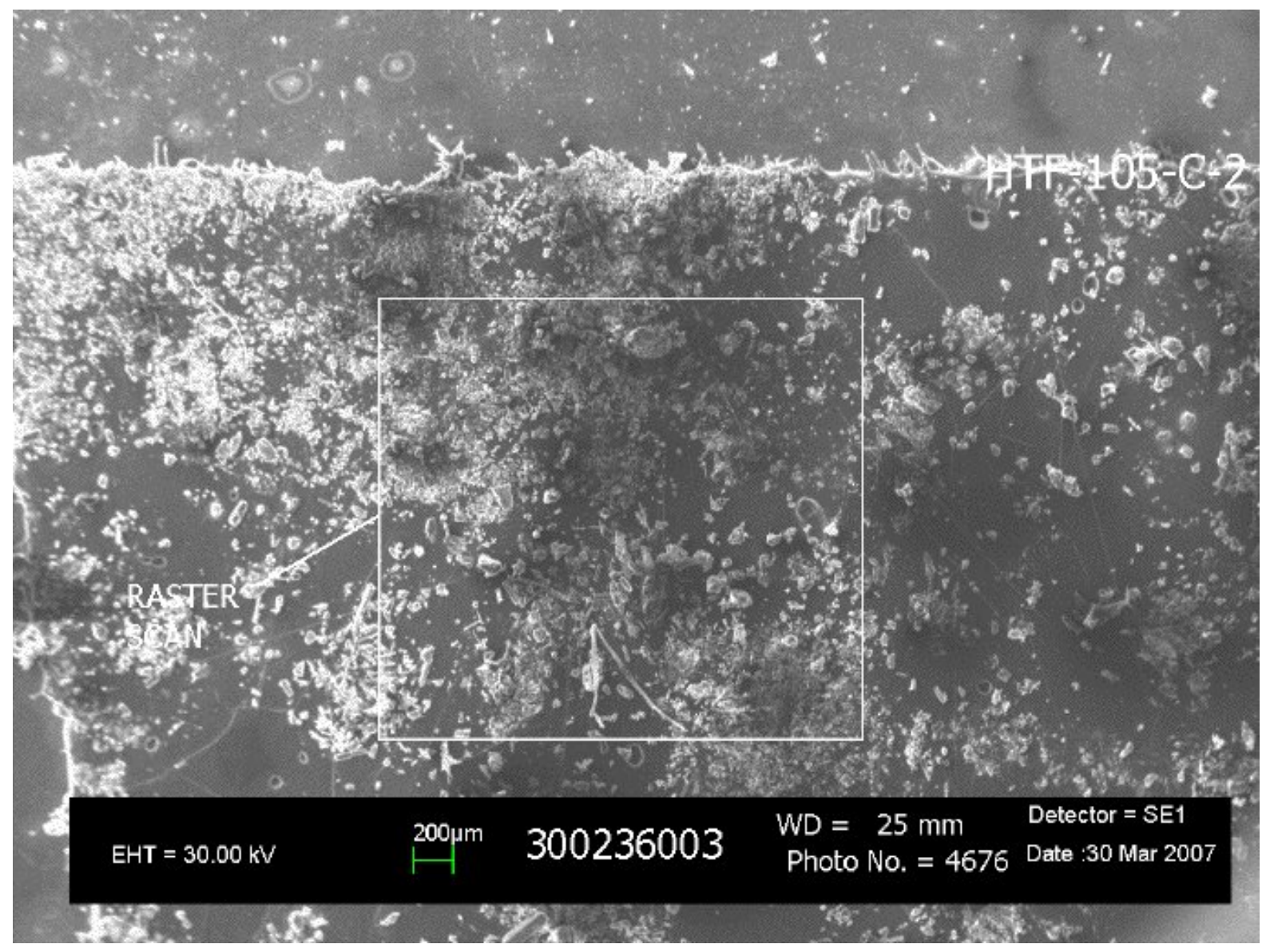

Figure A.20 SEM Micrograph of Solids from Tank 16H Sample HTF-16-06-105C-2 (18X Magnification)

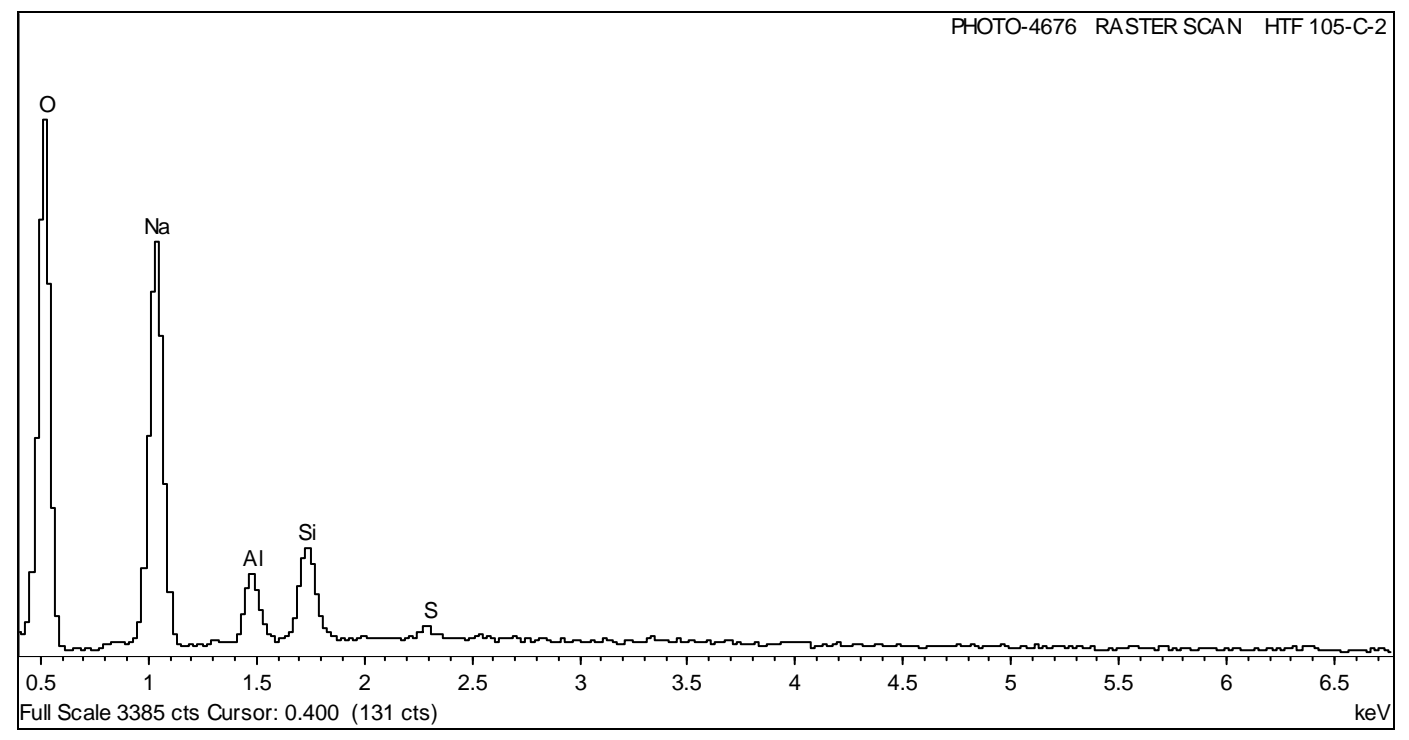

Figure A.21 Spectrum of Raster Scan from Figure A.20 


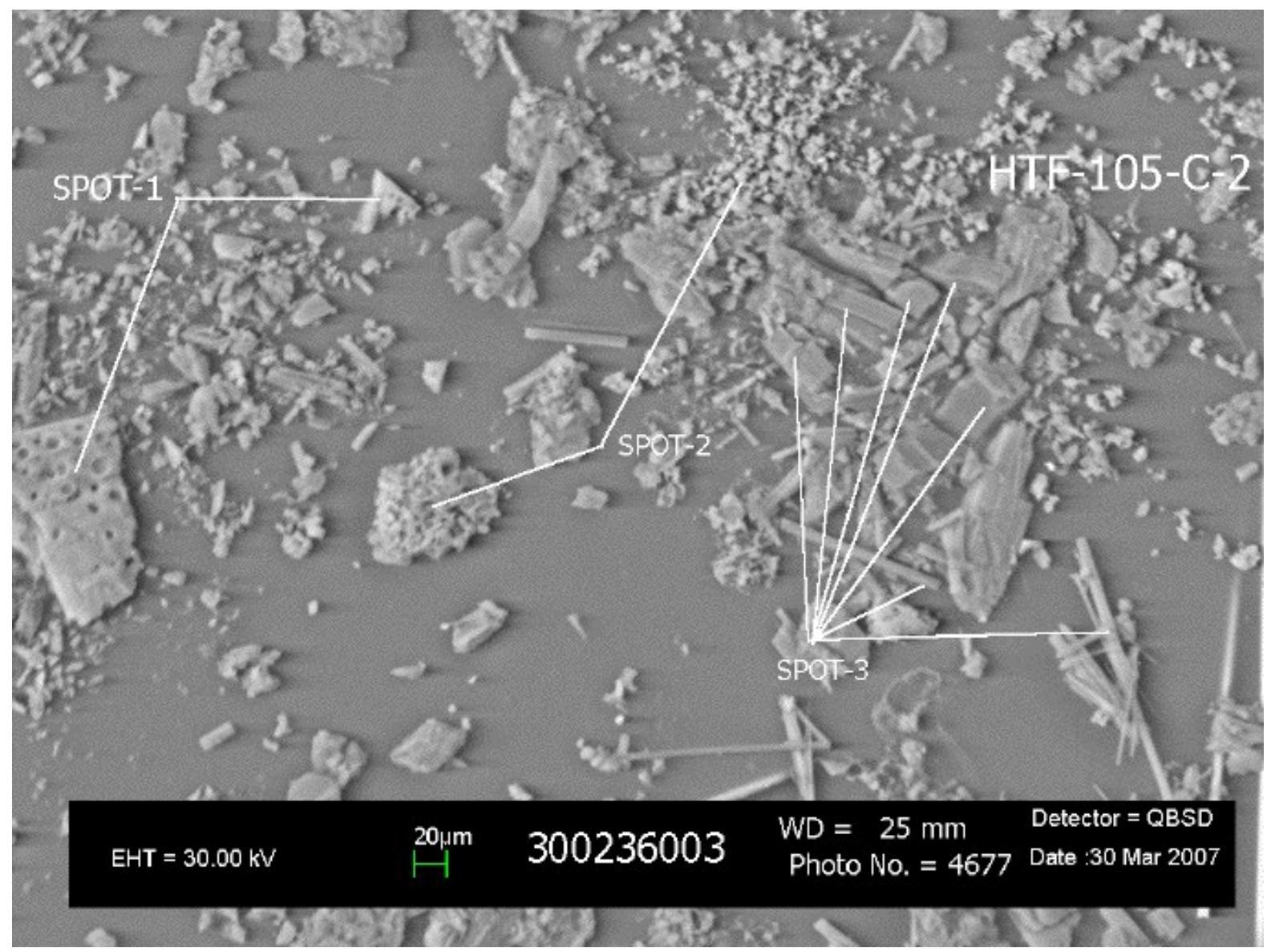

Figure A.22 SEM Micrograph of Solids from Tank 16H Sample HTF-16-06-105C-2 (143X Magnification)

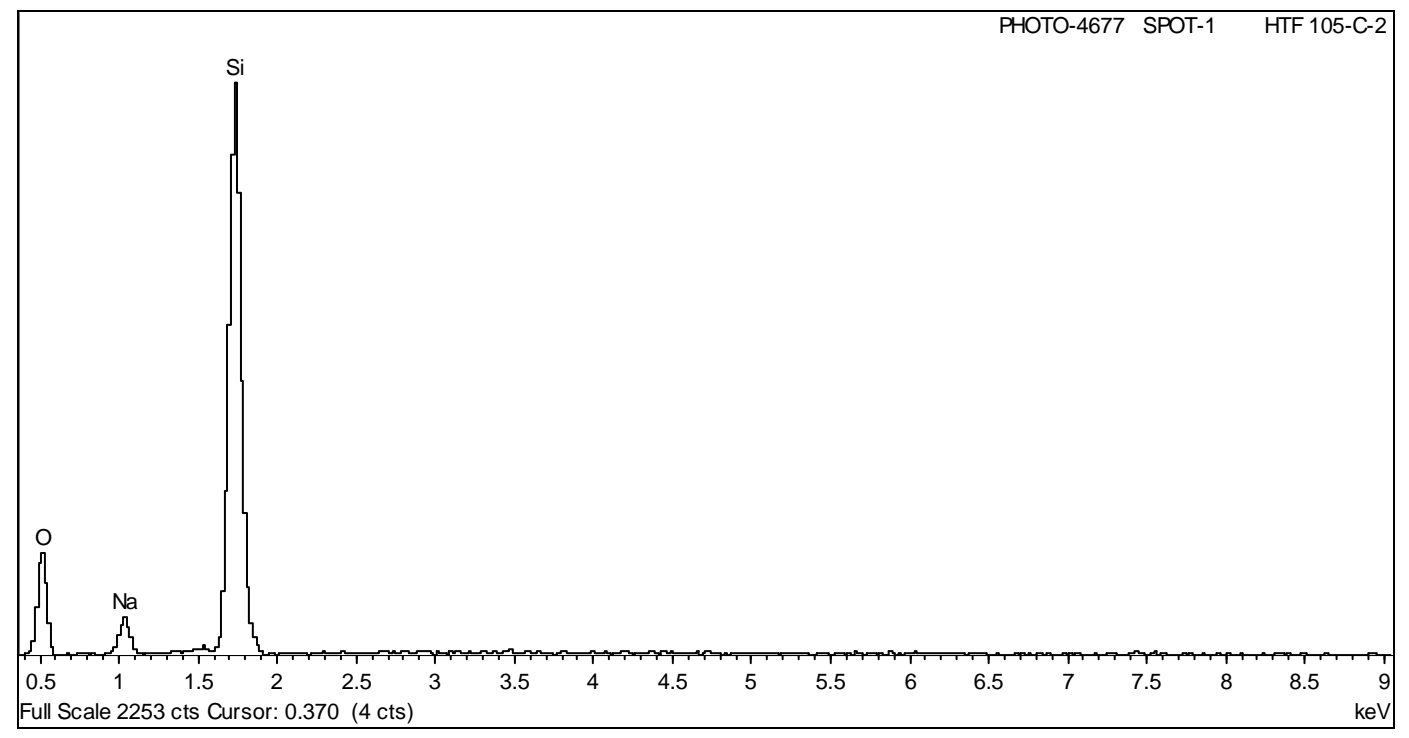

Figure A.23 Spectrum of Spot 1 from Figure A.22 
WSRC-STI-2008-00203, REV. 0

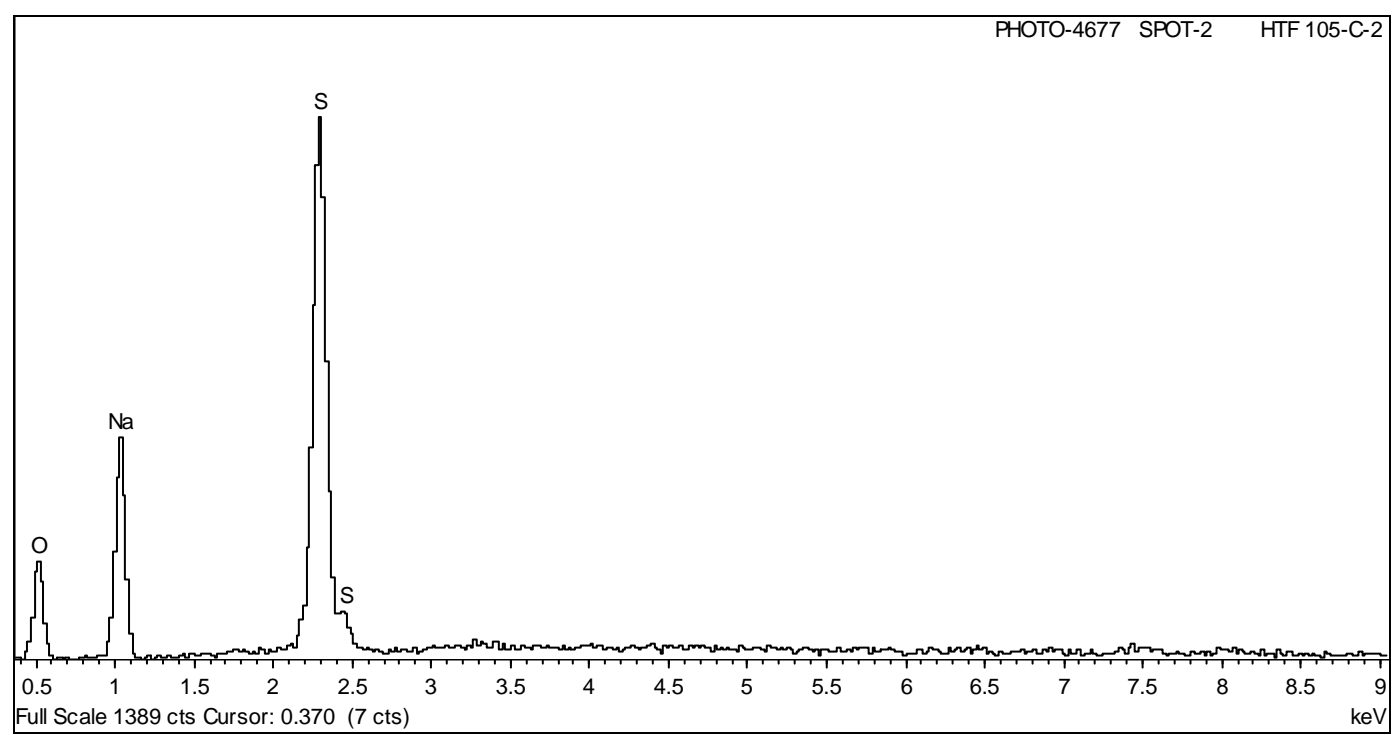

Figure A.24 Spectrum of Spot 2 from Figure A.22

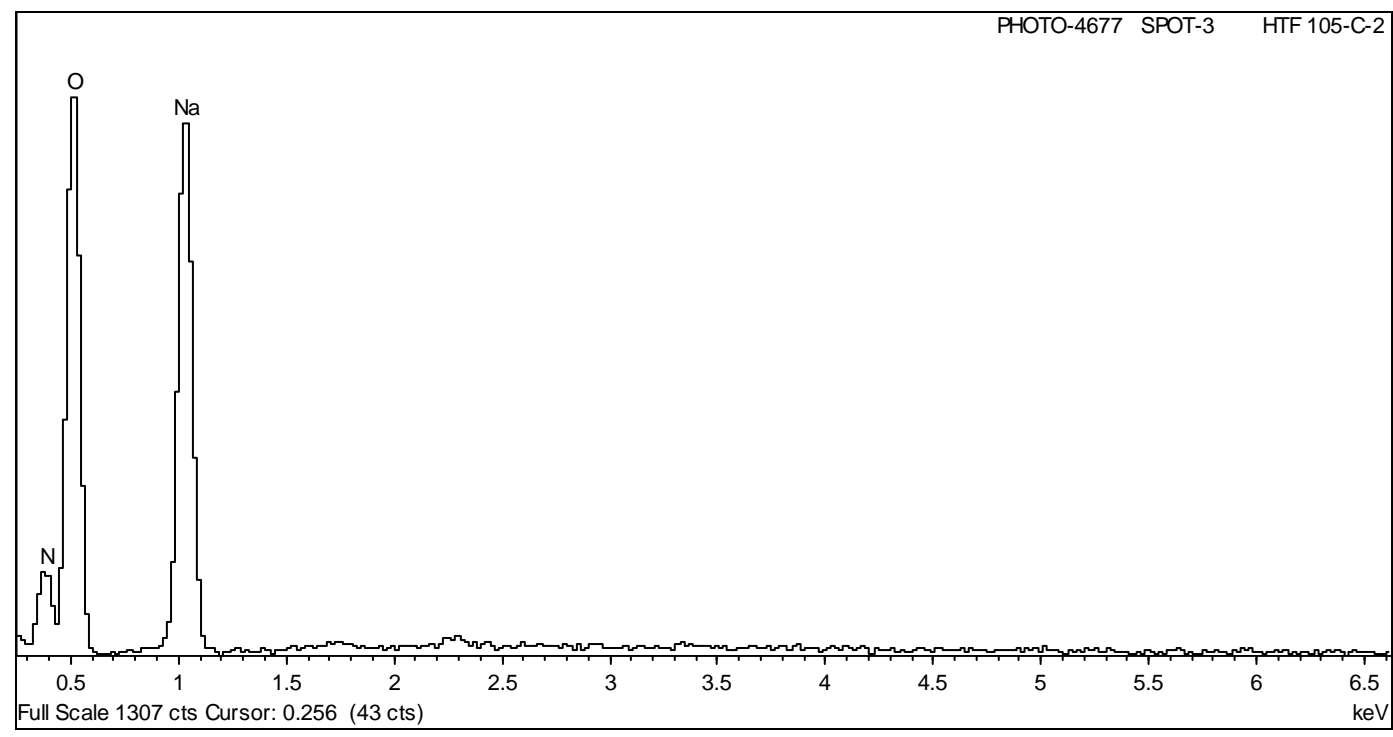

Figure A.25 Spectrum of Spot 3 from Figure A.22 


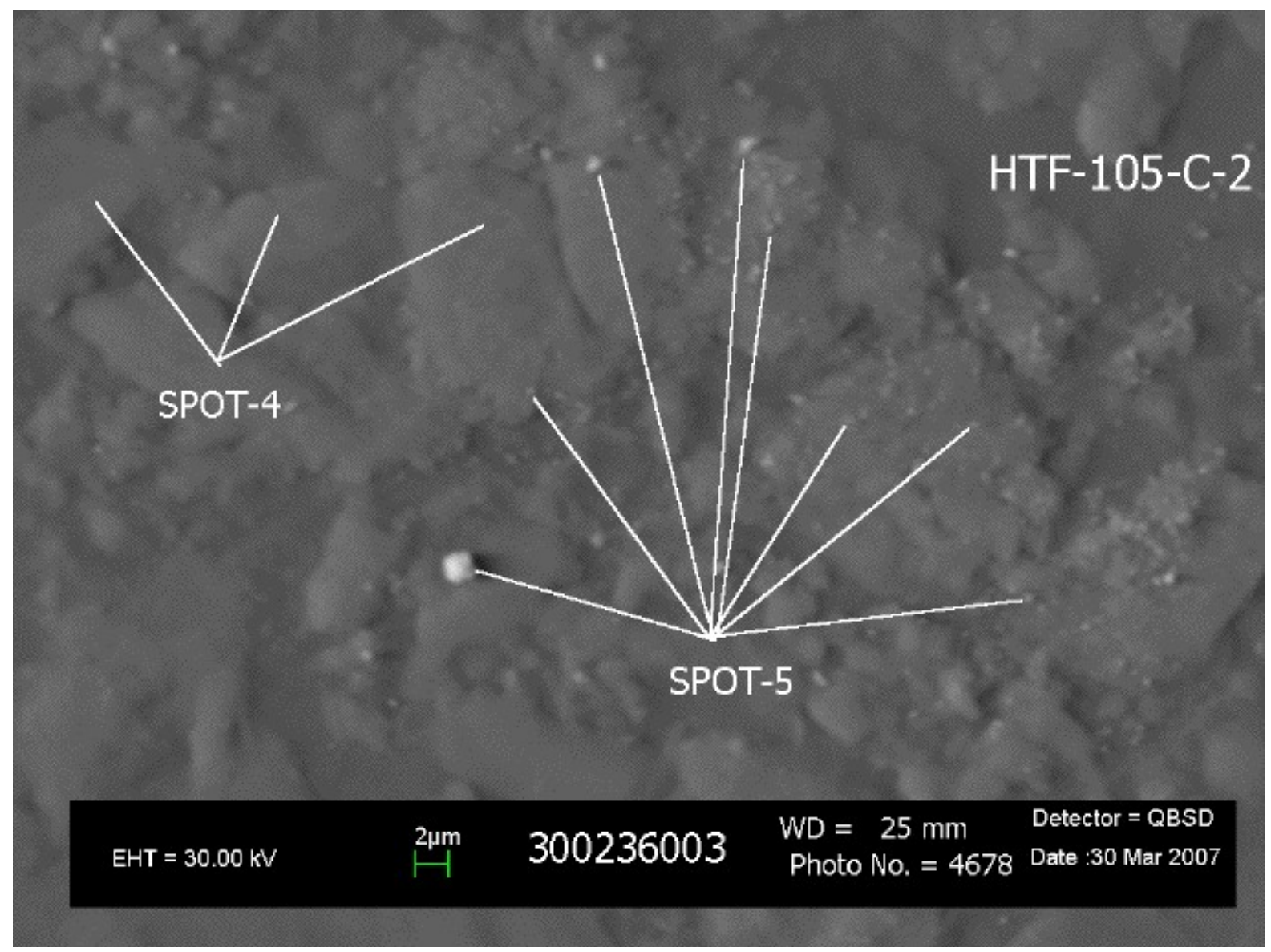

Figure A.26 SEM Micrograph of Solids from Tank 16H Sample HTF-16-06-105C-2 (1500X Magnification)

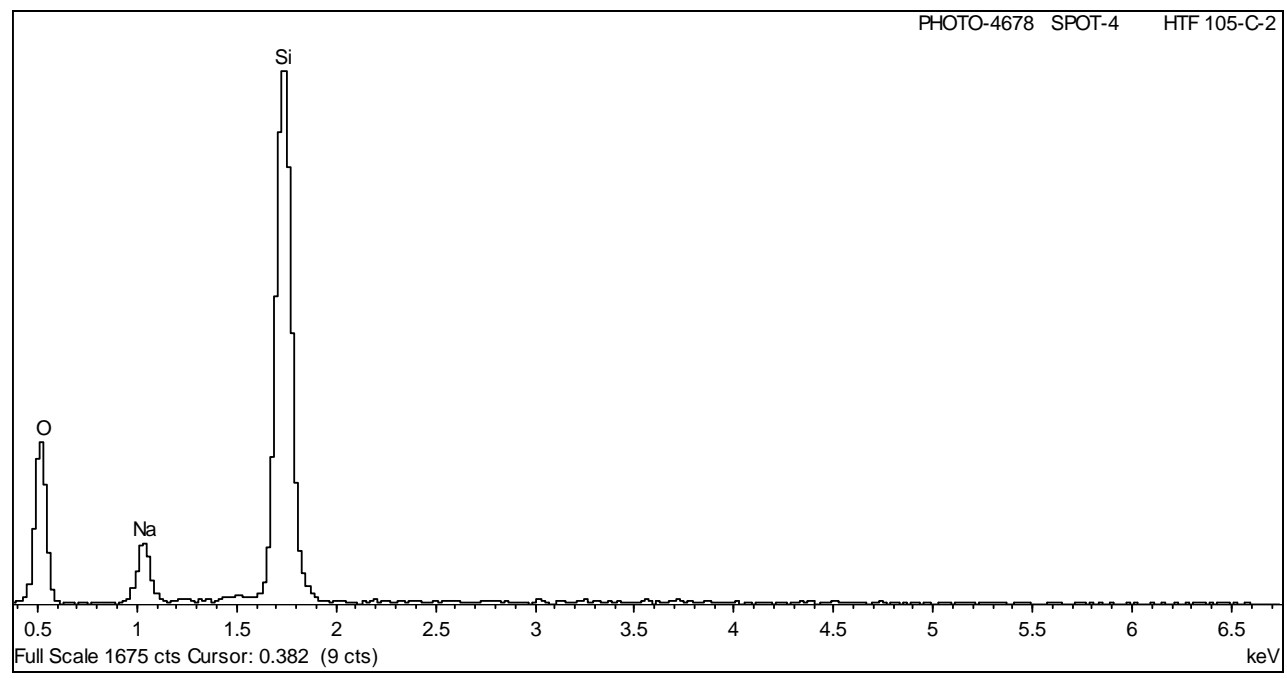

Figure A.27 Spectrum of Spot 4 from Figure A.26 
WSRC-STI-2008-00203, REV. 0

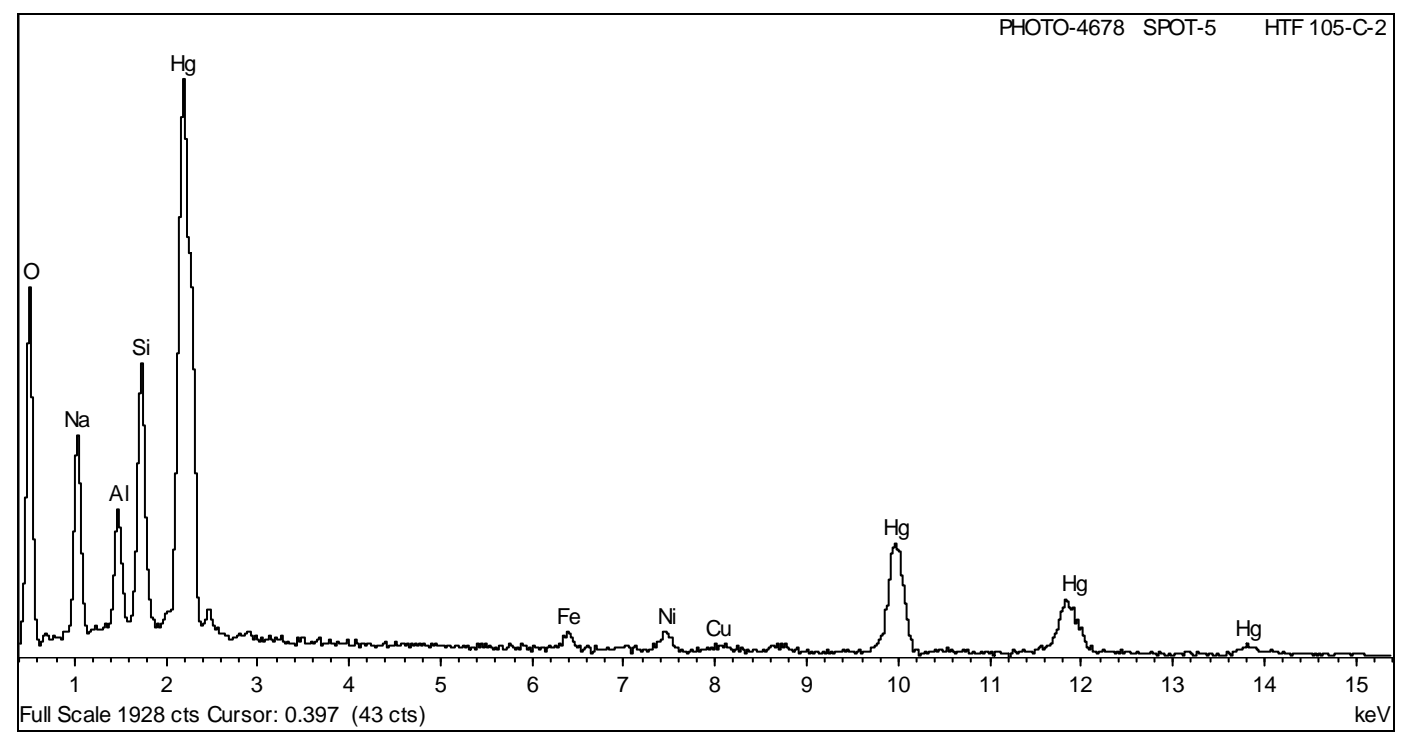

Figure A.28 Spectrum of Spot 5 from Figure A.26 


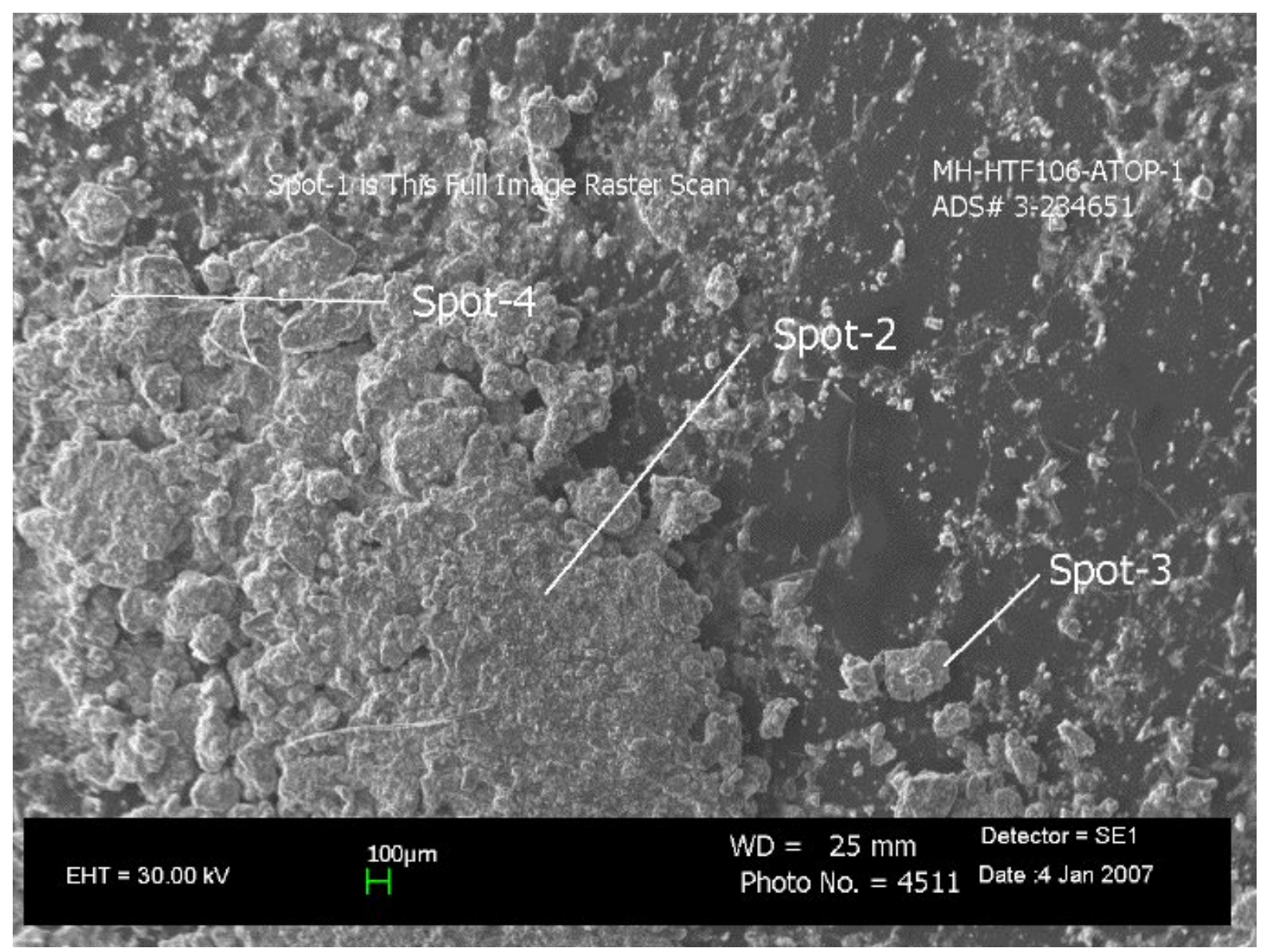

Figure A.29 SEM Micrograph of Solids from Tank 16H Sample HTF-16-06-106ATOP-1 (20X Magnification)

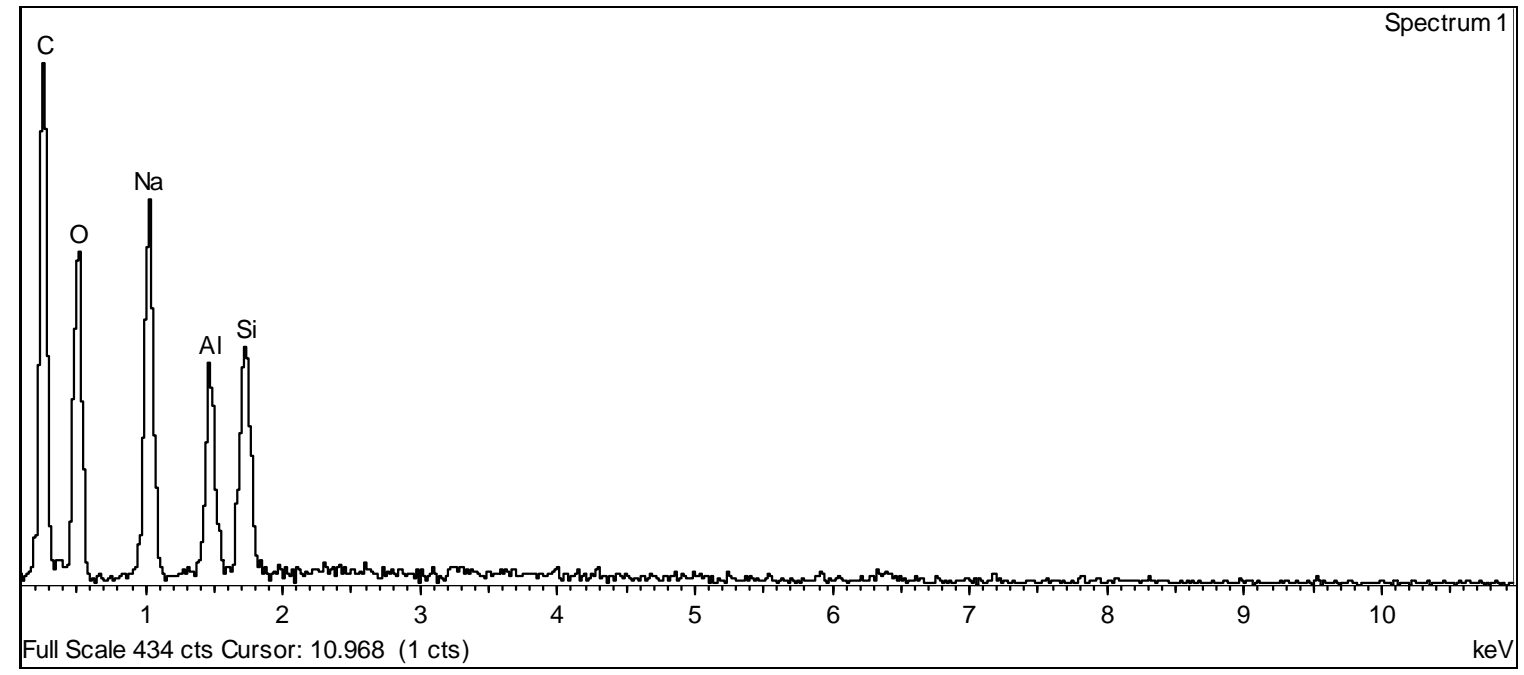

Figure A.30 Spectrum of Raster Scan from Figure A.29 
WSRC-STI-2008-00203, REV. 0

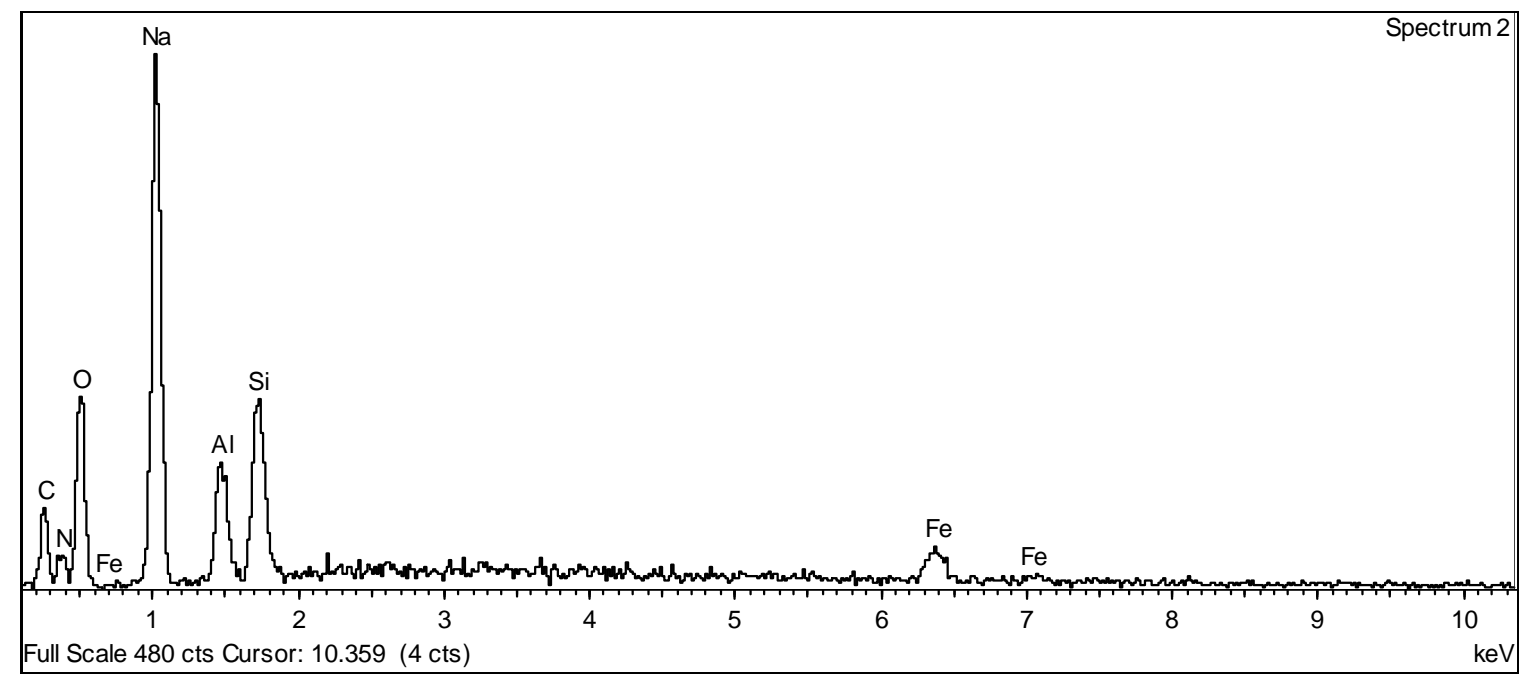

Figure A.31 Spectrum of Spot 2 from Figure A.29

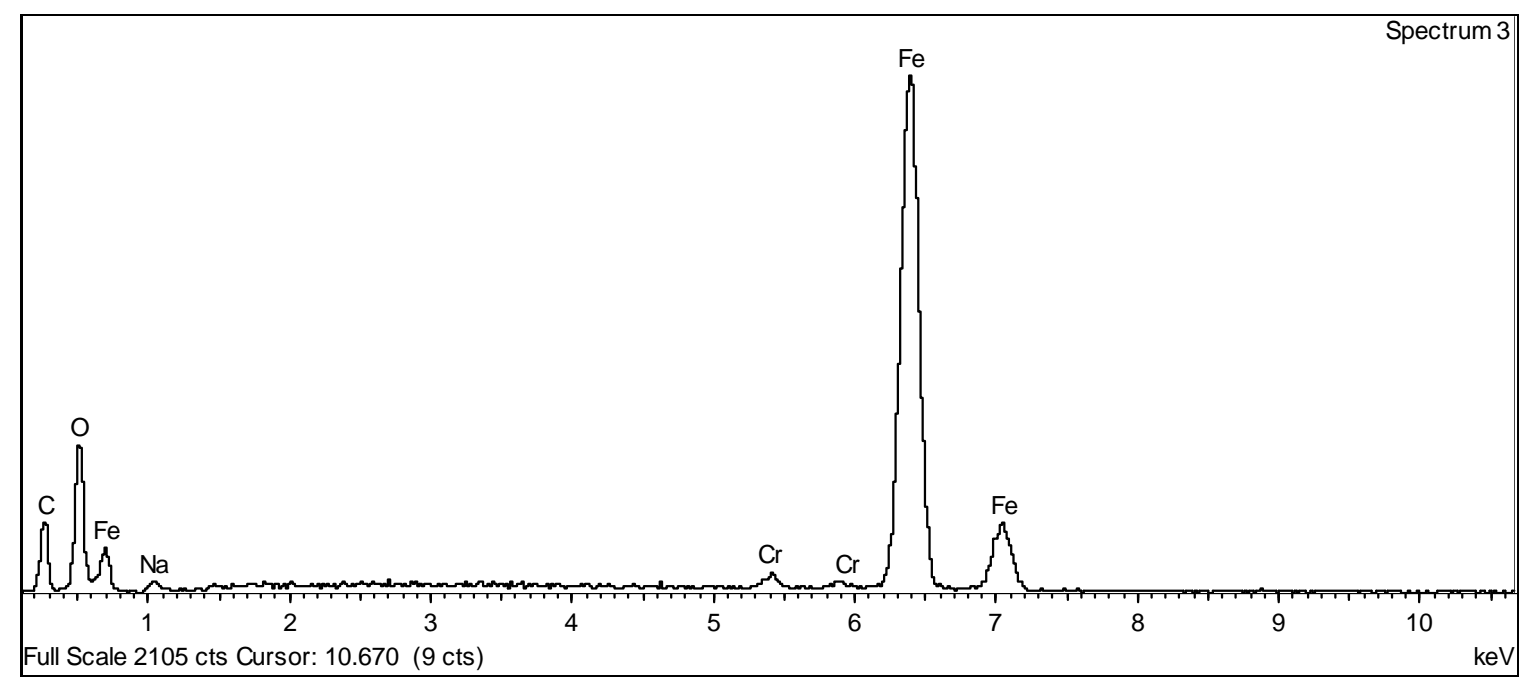

Figure A.32 Spectrum of Spot 3 from Figure A.29 
WSRC-STI-2008-00203, REV. 0

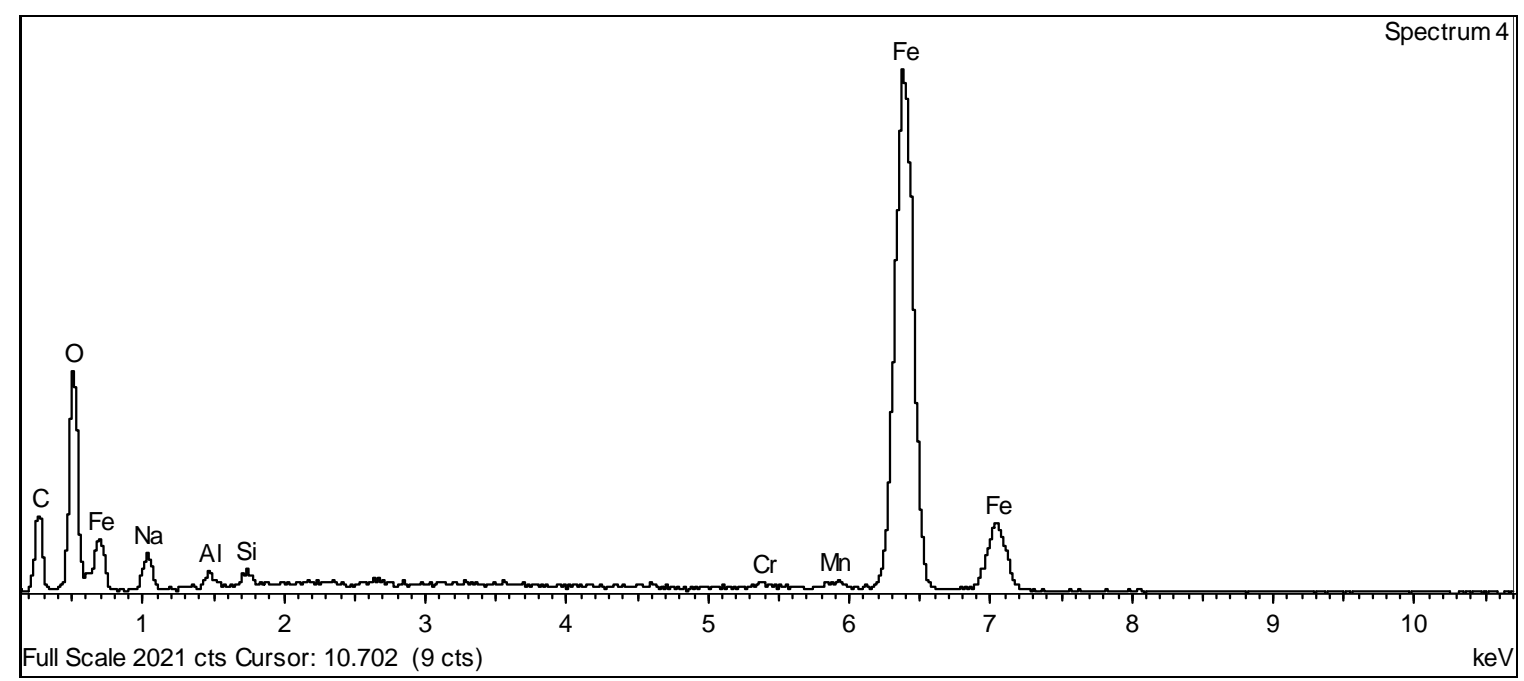

Figure A.33 Spectrum of Spot 4 from Figure A.29 


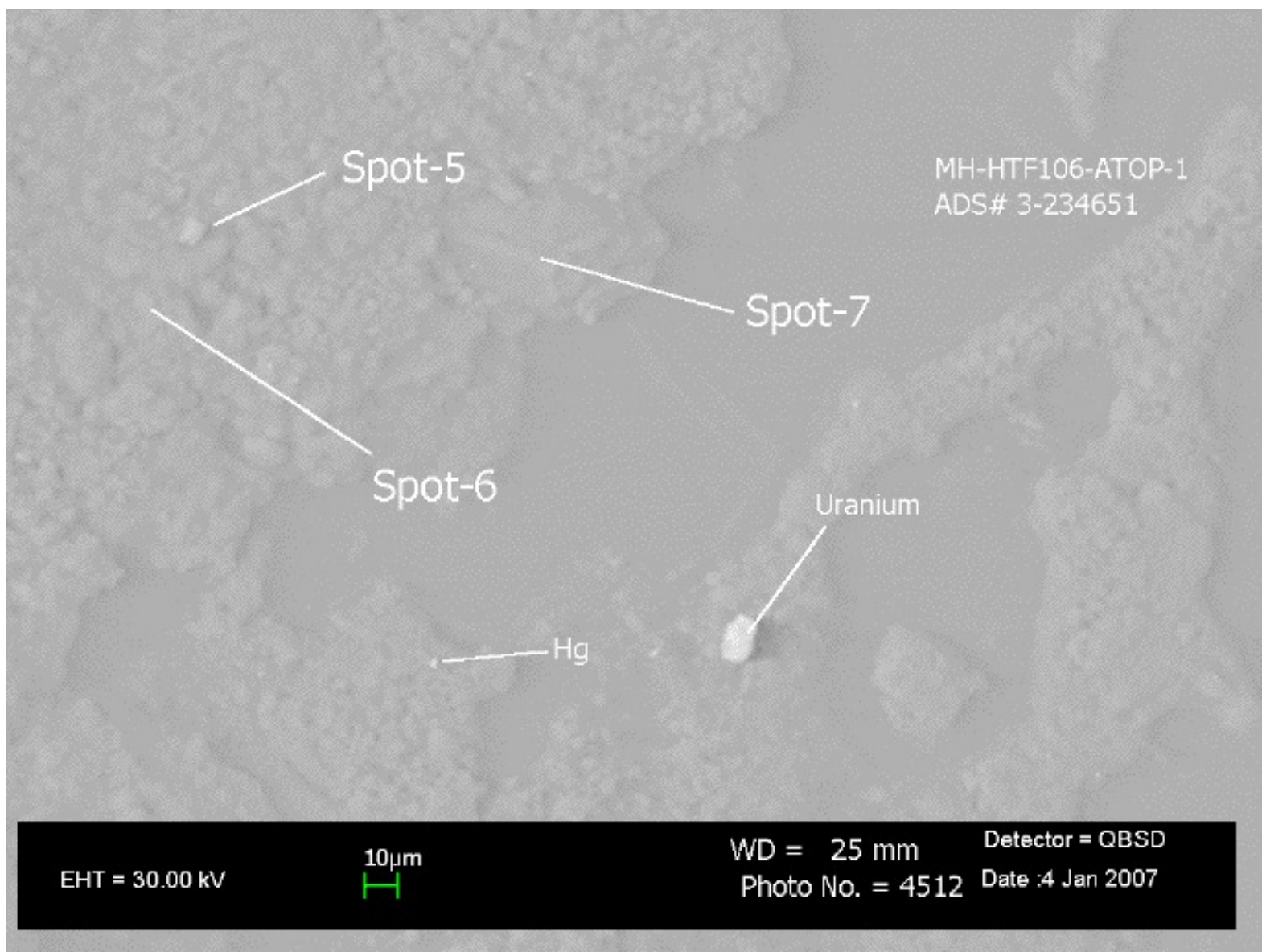

Figure A.34 SEM Micrograph of Solids from Tank 16H Sample HTF-16-06-106ATOP-1 (300X Magnification)

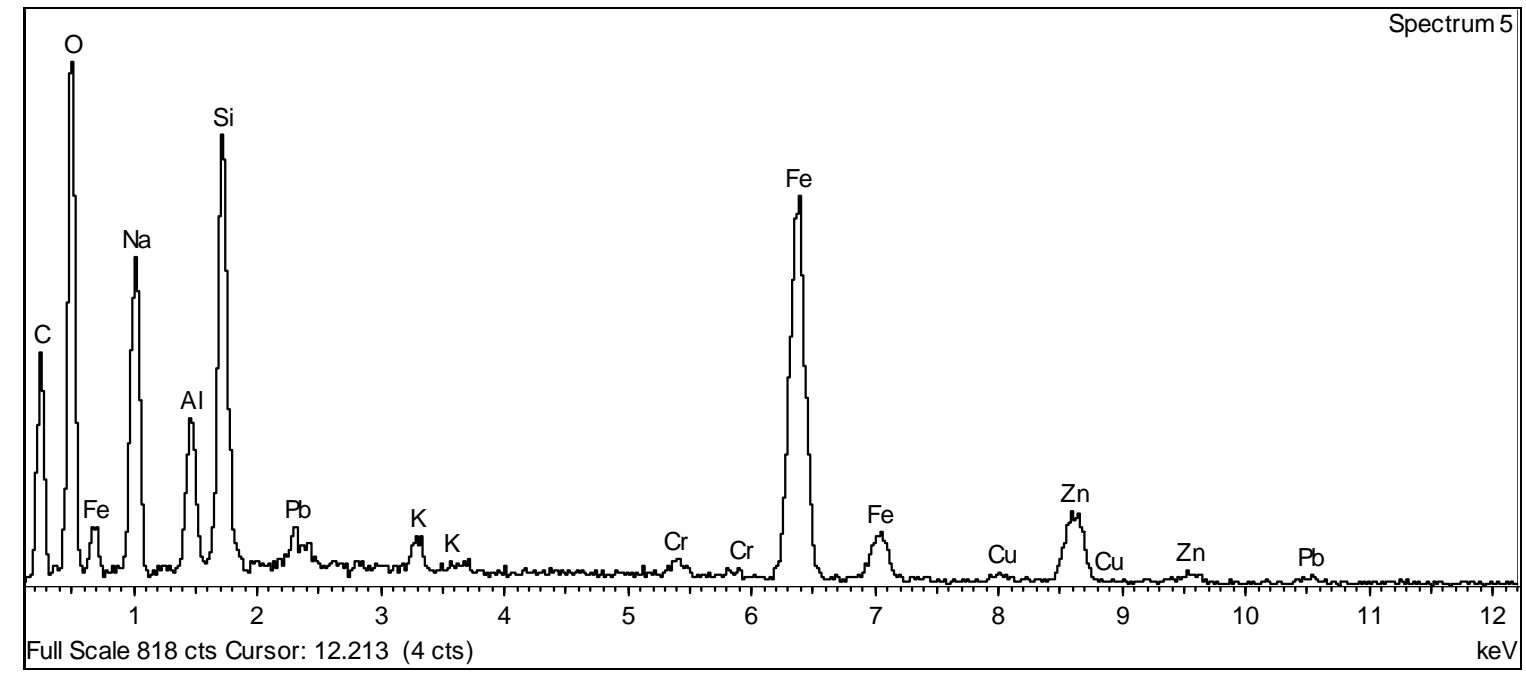

Figure A.35 Spectrum of Spot 5 from Figure A.34 
WSRC-STI-2008-00203, REV. 0

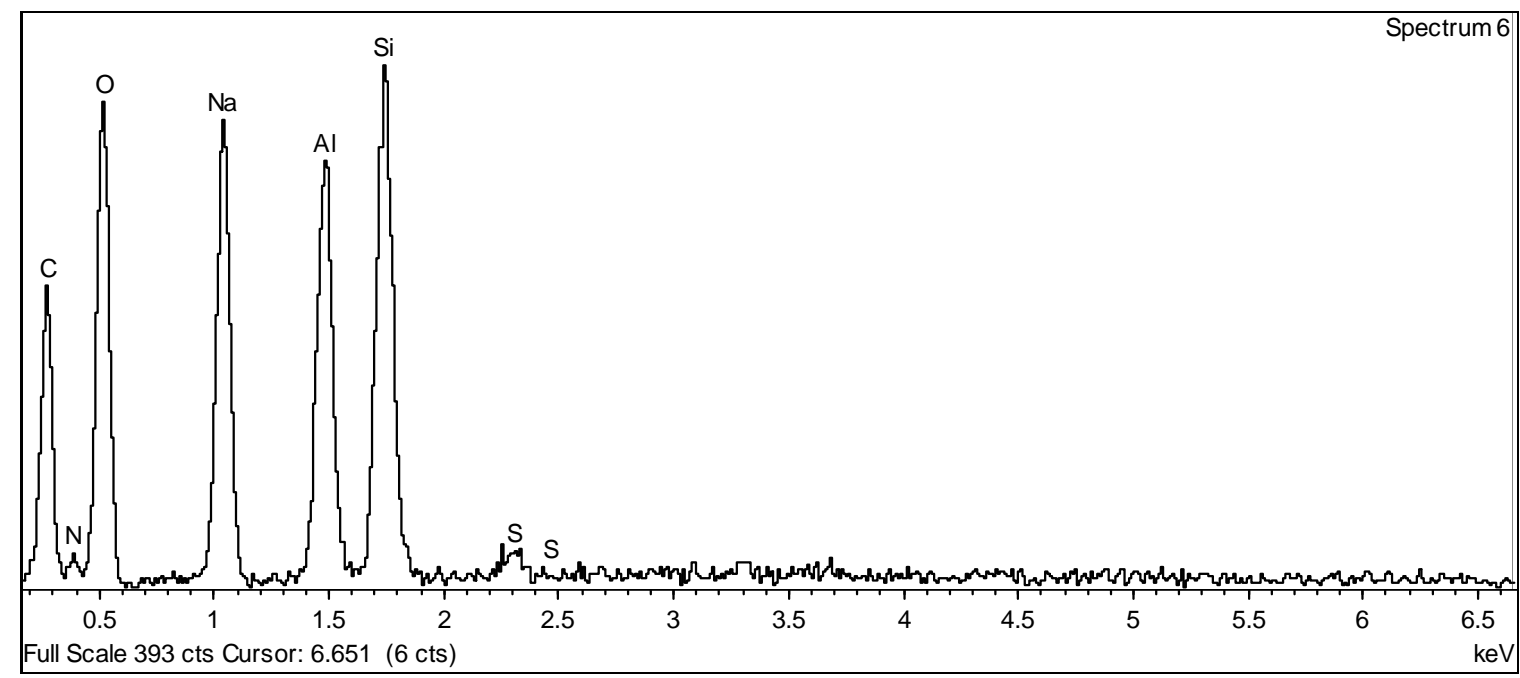

Figure A.36 Spectrum of Spot 6 from Figure A.34

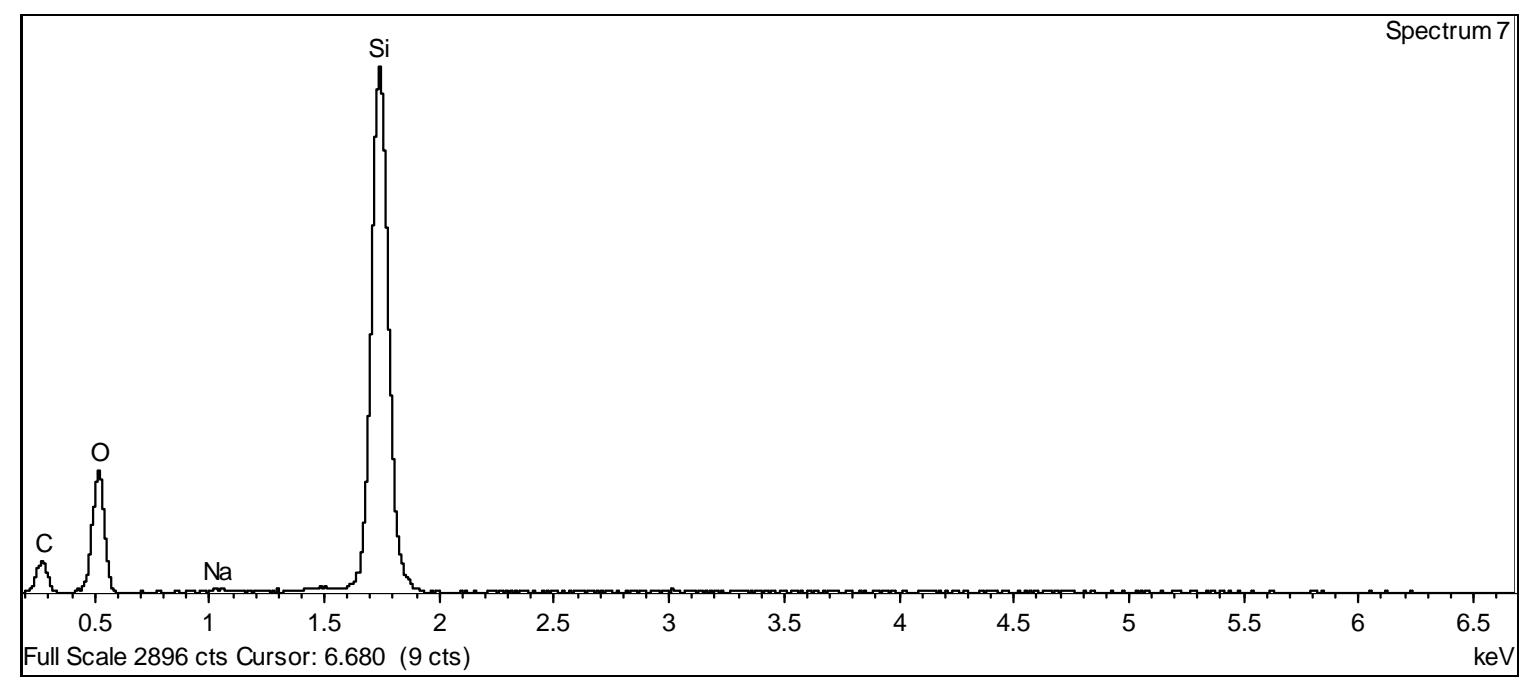

Figure A.37 Spectrum of Spot 7 from Figure A.34 


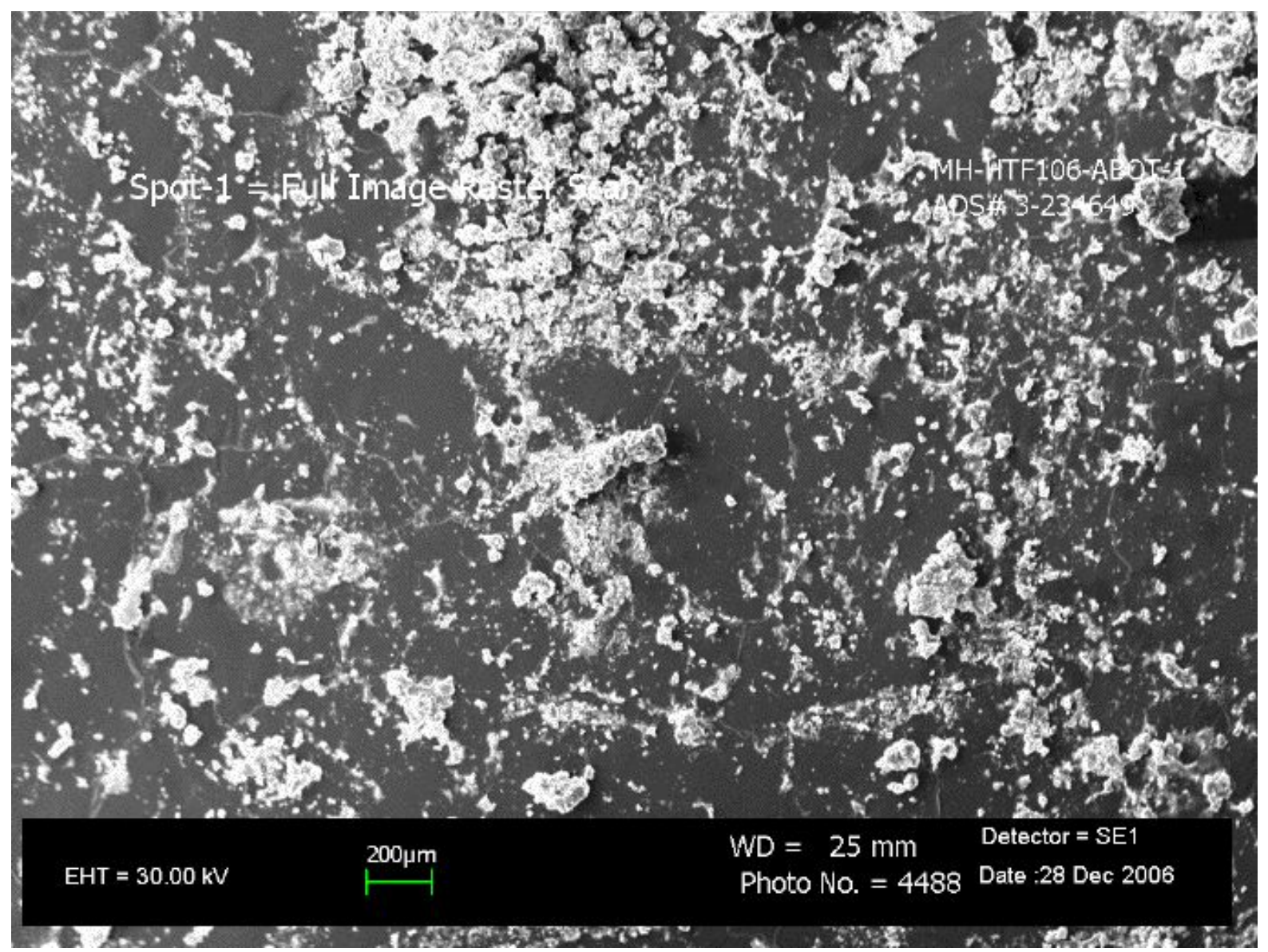

Figure A.38 SEM Micrograph of Solids from Tank 16H Sample HTF-16-06-106ABOT-1 (30X Magnification)

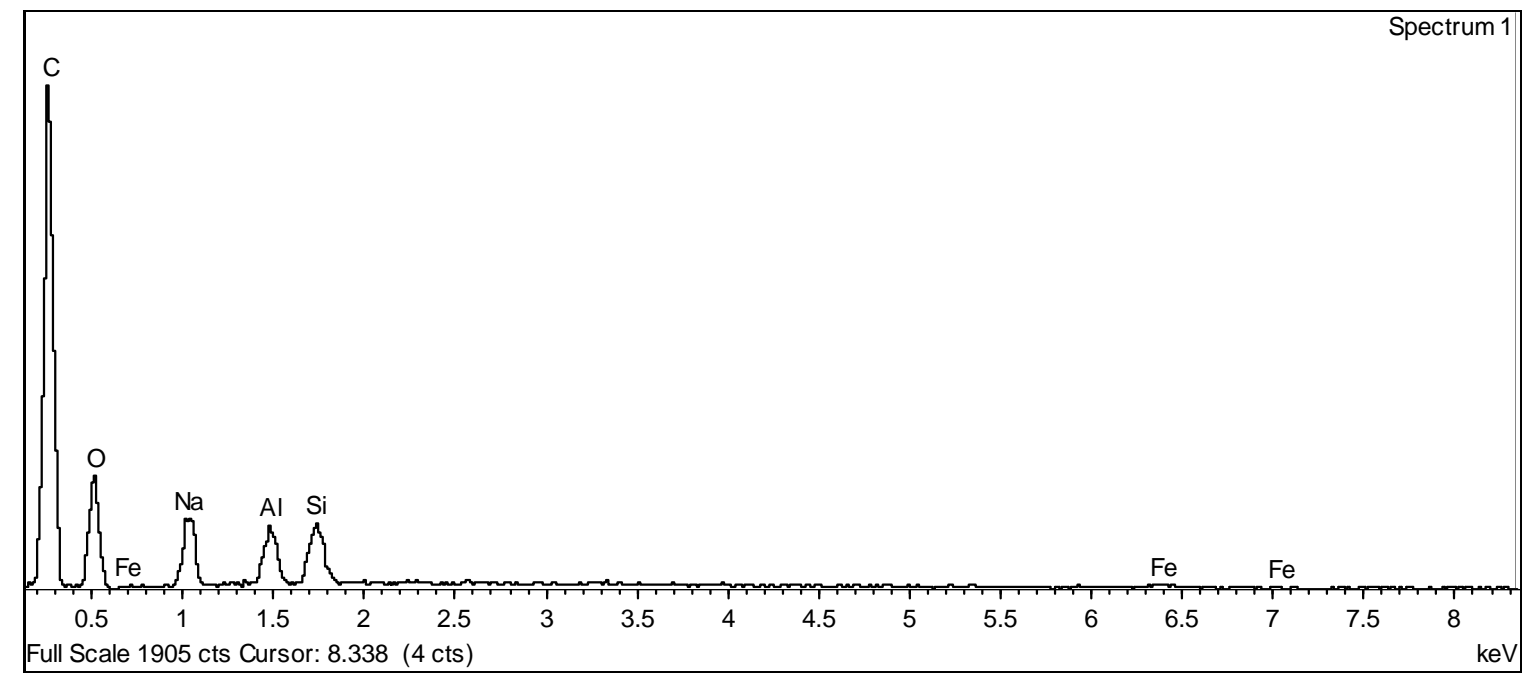

Figure A.39 Spectrum of Raster Scan from Figure A.38 


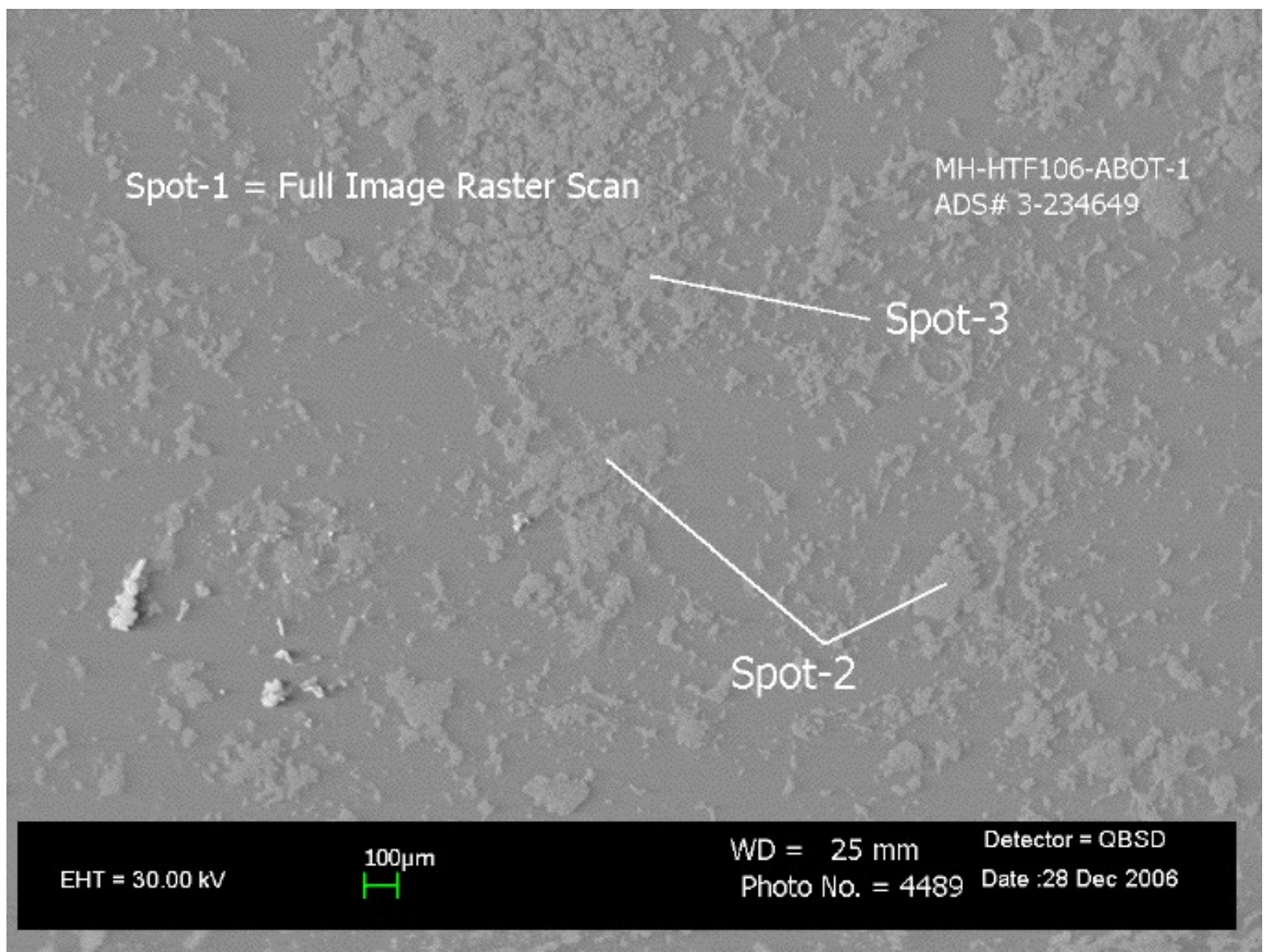

Figure A.40 SEM Micrograph of Solids from Tank 16H Sample HTF-16-06-106ABOT-1 (30X Magnification)

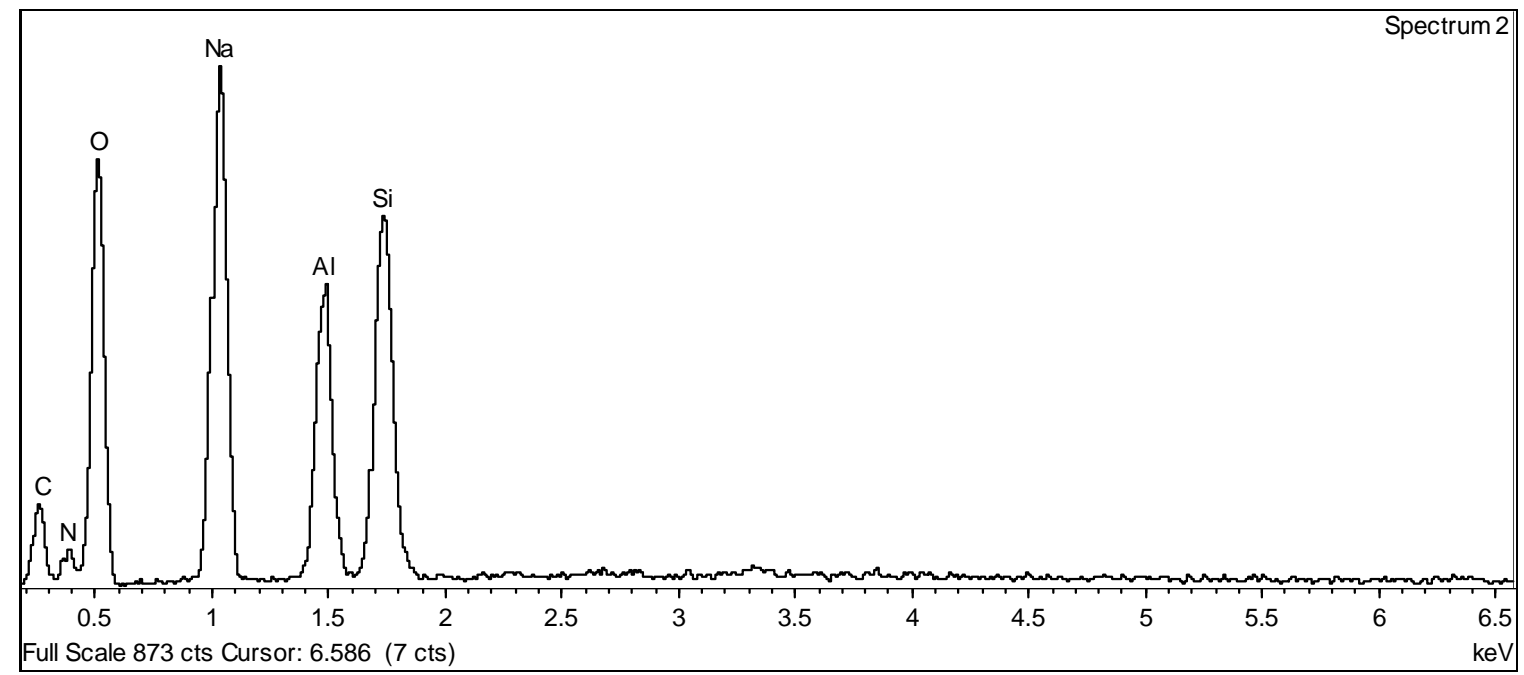

Figure A.41 Spectrum of Spot 2 from Figure A.40 
WSRC-STI-2008-00203, REV. 0

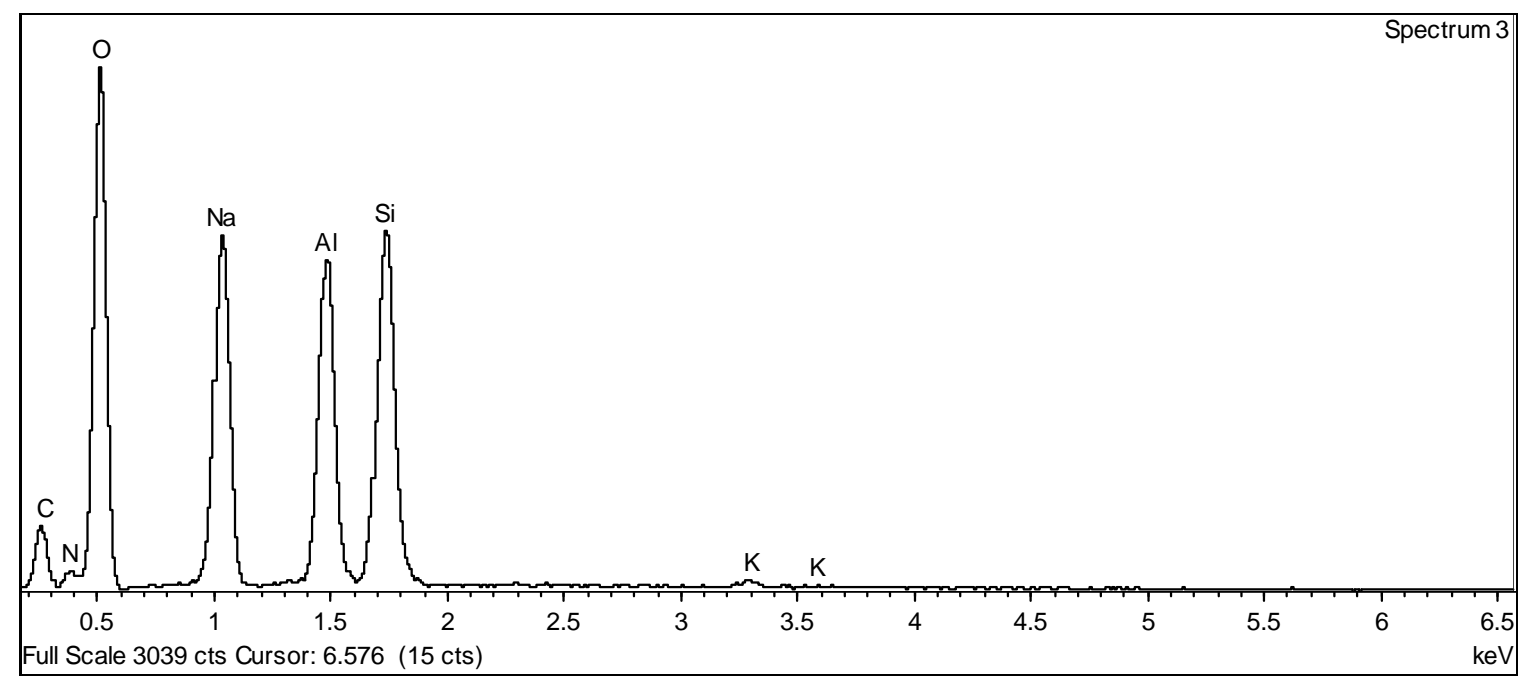

Figure A.42 Spectrum of Spot 3 from Figure A.40 


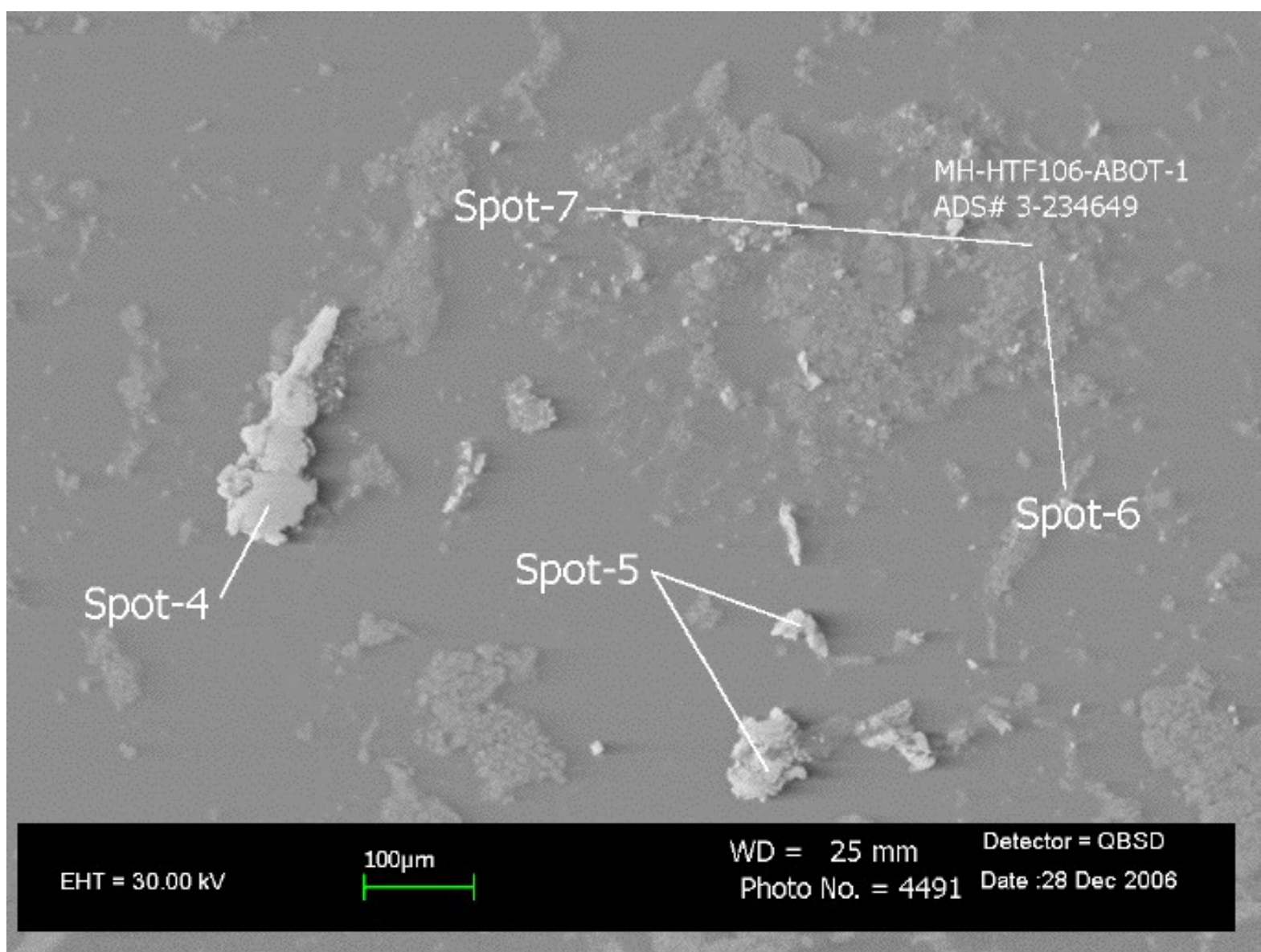

Figure A.43 SEM Micrograph of Solids from Tank 16H Sample HTF-16-06-106ABOT-1 (100X Magnification)

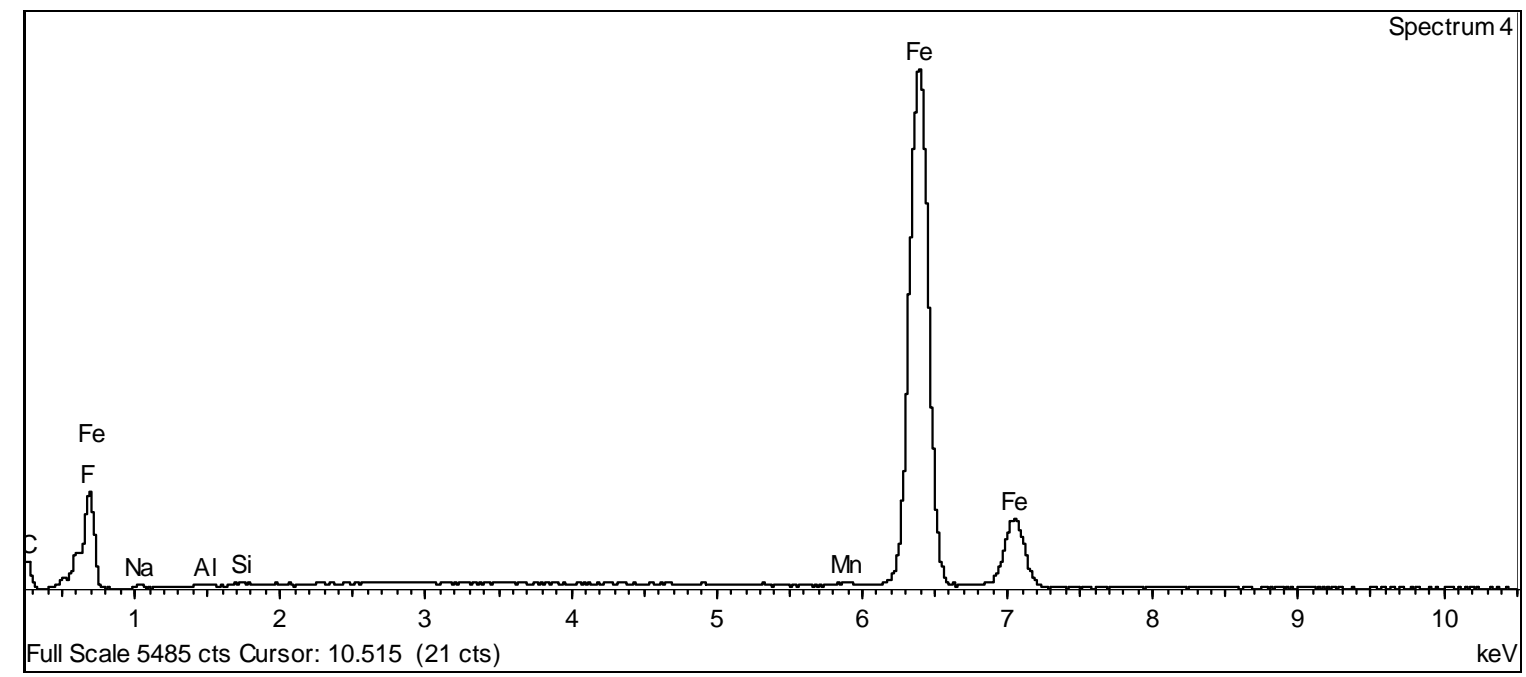

Figure A.44 Spectrum of Spot 4 from Figure A.43 
WSRC-STI-2008-00203, REV. 0

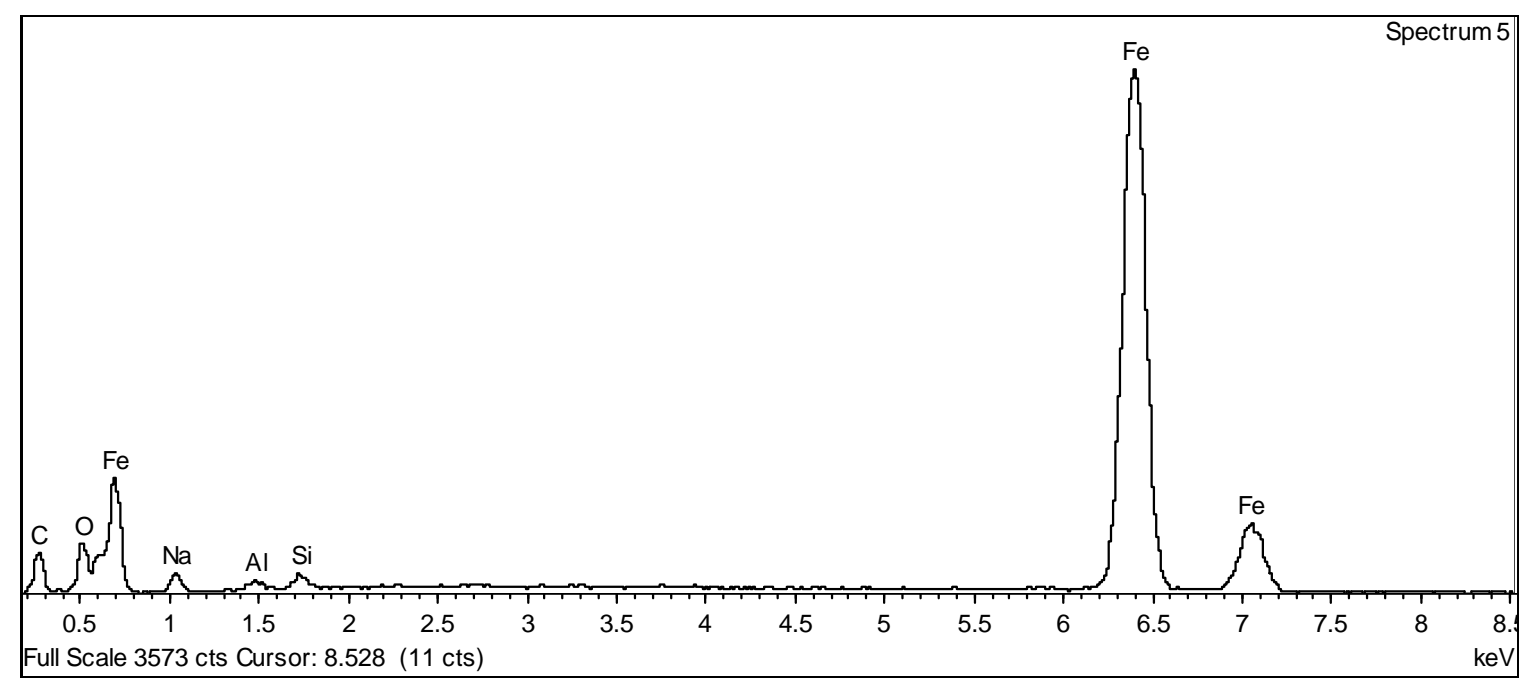

Figure A.45 Spectrum of Spot 5 from Figure A.43

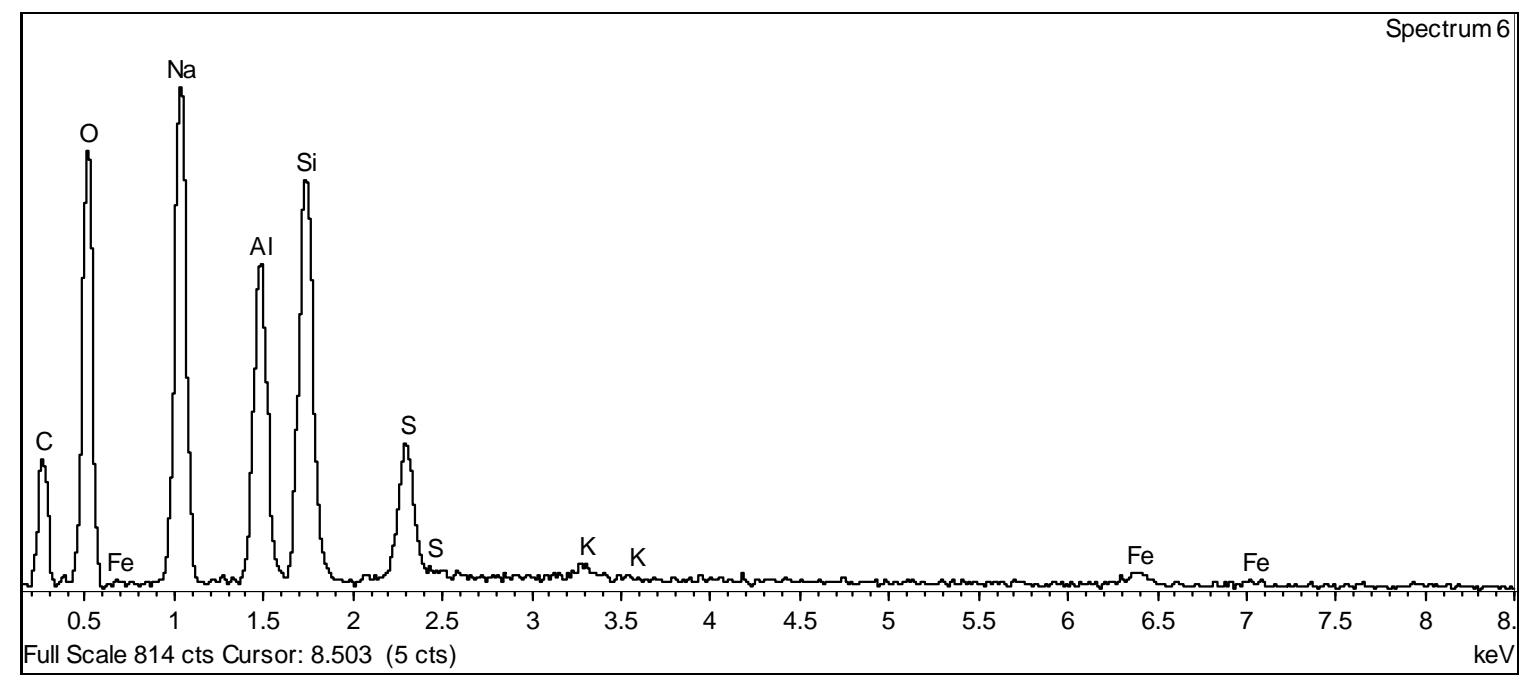

Figure A.46 Spectrum of Spot 6 from Figure A.43 
WSRC-STI-2008-00203, REV. 0

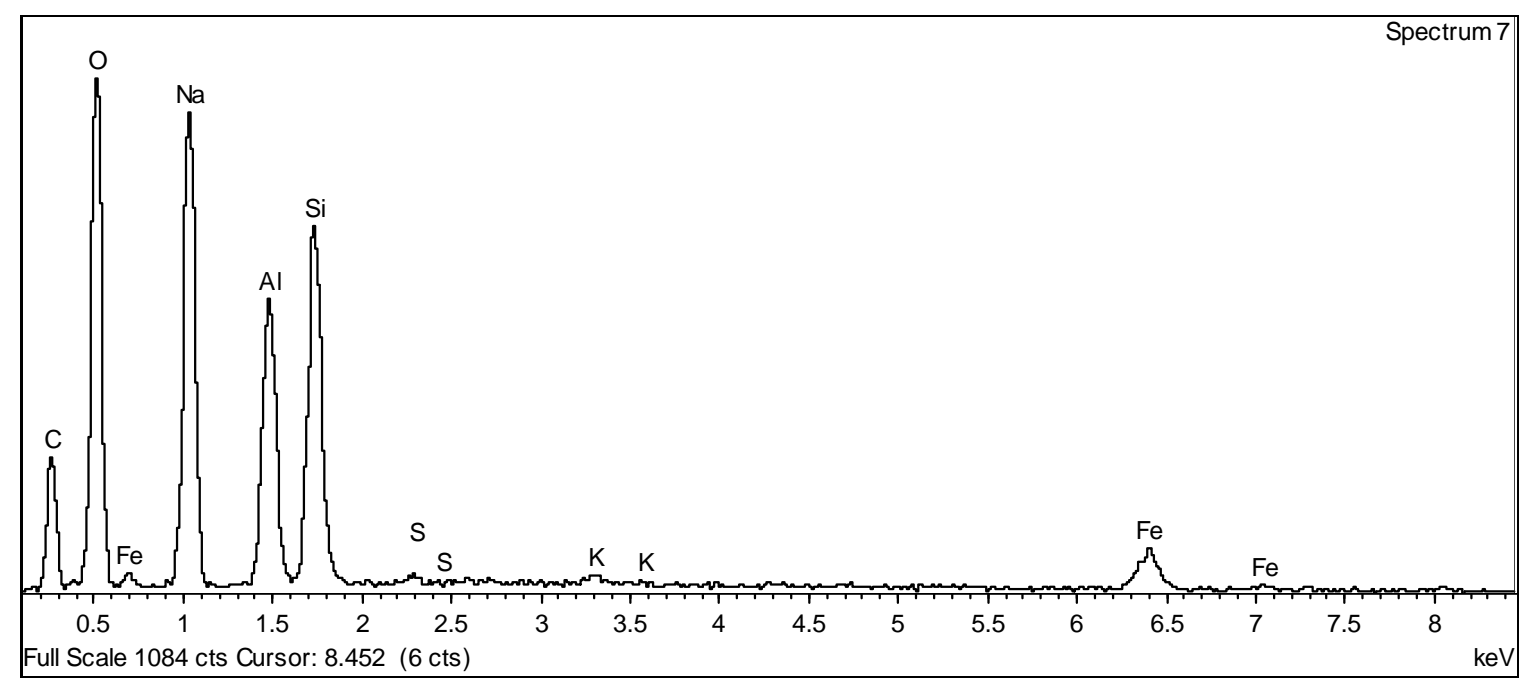

Figure A.47 Spectrum of Spot 7 from Figure A.43 


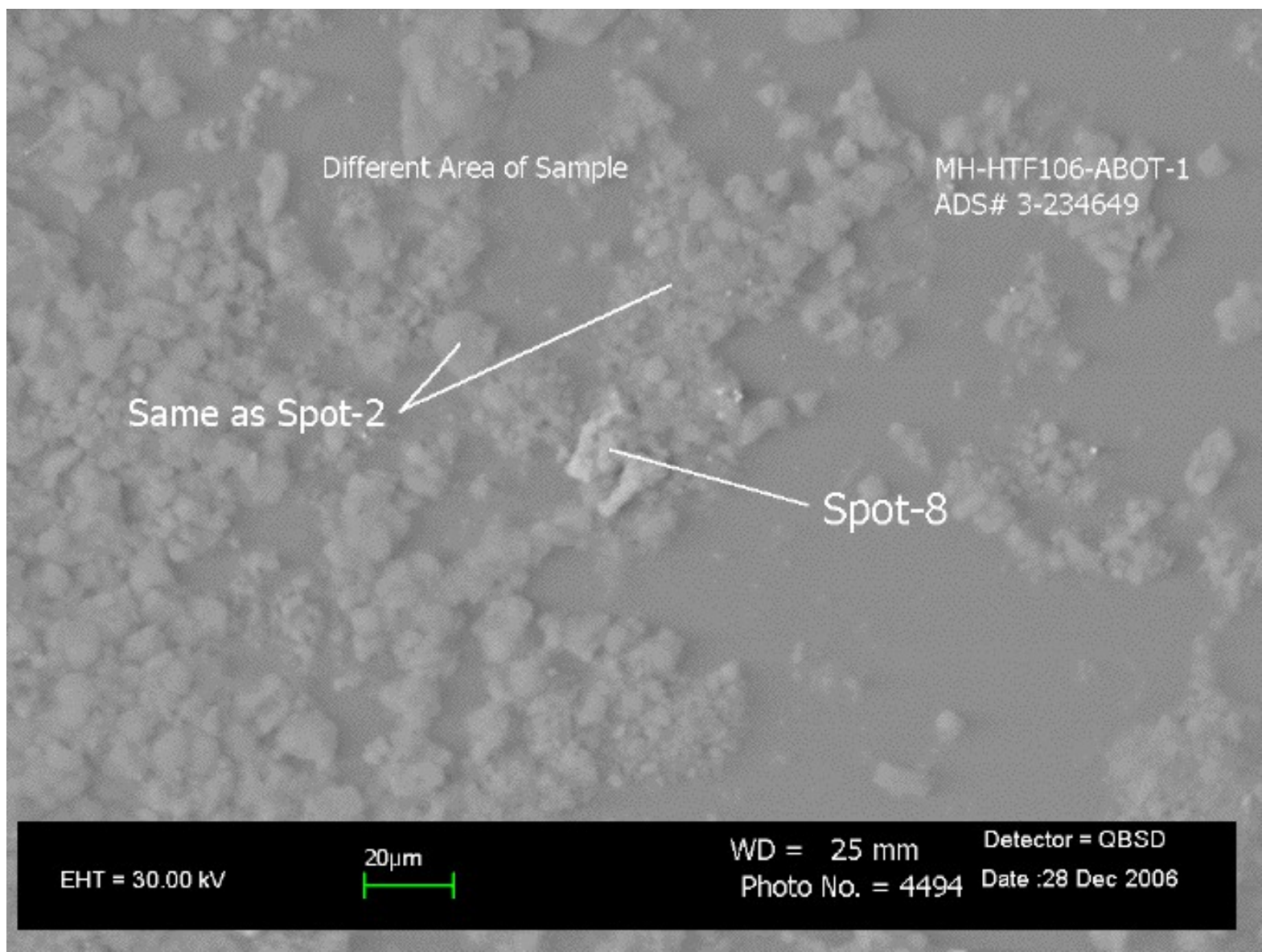

Figure A.48 SEM Micrograph of Solids from Tank 16H Sample HTF-16-06-106ABOT-1 (400X Magnification)

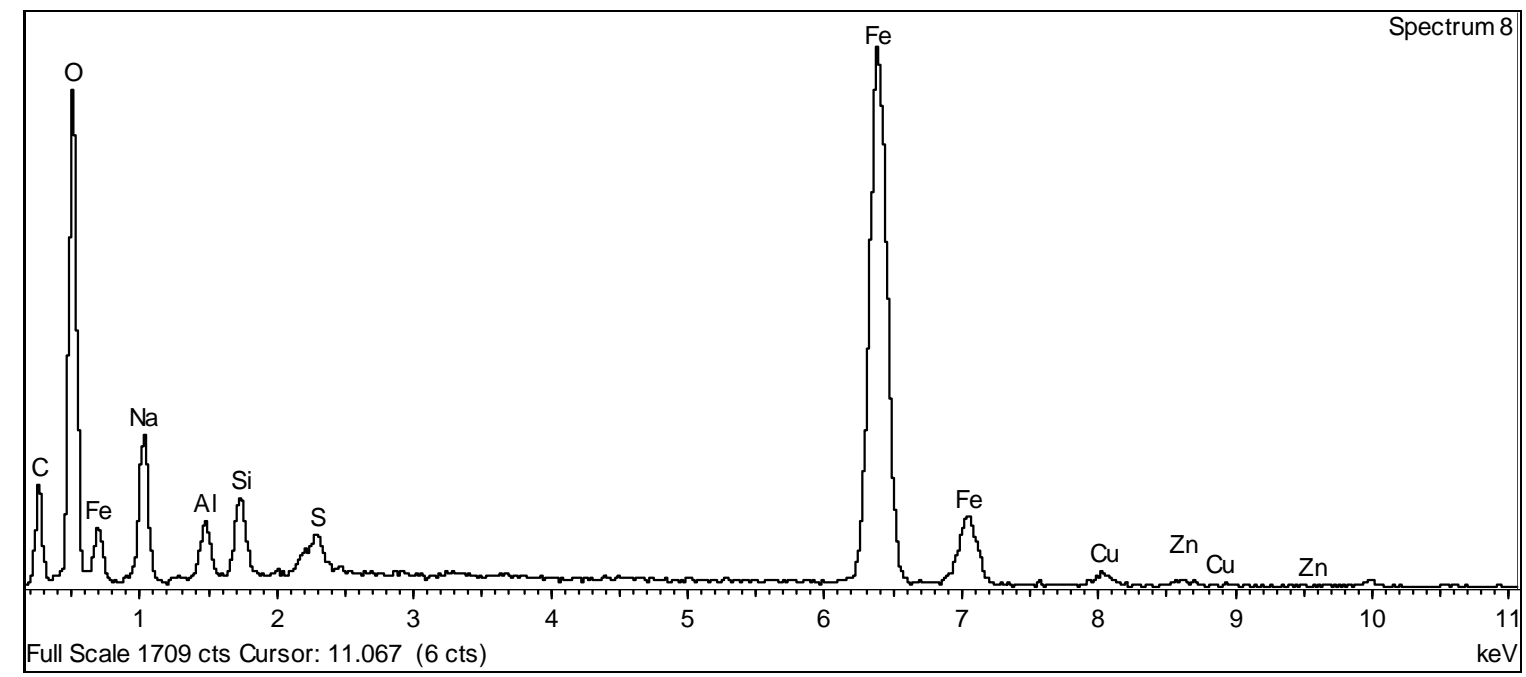

Figure A.49 Spectrum of Spot 8 from Figure A.48 